\title{
DISTRIBUTION OF FISH, BENTHIC INVERTEBRATE, AND ALGAL COMMUNITIES IN RELATION TO PHYSICAL AND CHEMICAL CONDITIONS, YAKIMA RIVER BASIN, WASHINGTON, 1990
}

By Thomas F. Cuffney, Michael R. Meador, Stephen D. Porter, and Martin E. Gurtz

\section{U.S. GEOLOGICAL SURVEY}

Water Resources Investigations Report 96-4280

Raleigh, North Carolina 


\title{
U.S. DEPARTMENT OF THE INTERIOR \\ BRUCE BABBITT, Secretary
}

\author{
U.S. GEOLOGICAL SURVEY \\ Gordon P. Eaton, Director
}

The use of firm, trade, and brand names in this report is for identification purposes only and does not constitute endorsement by the U.S. Geological Survey

For additional information write to:

District Chief

U.S. Geological Survey 3916 Sunset Ridge Road Raleigh, NC 27607-6416
Copies of this report can be purchased from:

U.S. Geological Survey Branch of Information Services Box 25286, Federal Center Denver, CO 80225-0286 


\section{FOREWORD}

The mission of the U.S. Geological Survey (USGS) is to assess the quantity and quality of the earth resources of the Nation and to provide information that will assist resource managers and policymakers at Federal, State, and local levels in making sound decisions. Assessment of water-quality conditions and trends is an important part of this overall mission.

One of the greatest challenges faced by water-resources scientists is acquiring reliable information that will guide the use and protection of the Nation's water resources. That challenge is being addressed by Federal, State, and local water-resource agencies and by many academic institutions. These organizations are collecting water-quality data for a host of purposes that include: compliance with permits and water-supply standards; development of remediation plans for specific contamination problems; operational decisions on industrial, wastewater, or watersupply facilities; and research on factors that affect water quality. An additional need for water-quality information is to provide a basis on which regional- and national-level policy decisions can be based. Wise decisions must be based on sound information. As a society we need to know whether certain types of water-quality problems are isolated or ubiquitous, whether there are significant differences in conditions among regions, whether the conditions are changing over time, and why these conditions change from place to place over time. The information can be used to help determine the efficacy of existing water-quality policies and to help analysts determine the need for and likely consequences of new policies.

To address these needs, the U.S. Congress appropriated funds in 1986 for the USGS to begin a pilot program in seven project areas to develop and refine the National Water-Quality Assessment (NAWQA) Program. In 1991, the USGS began full implementation of the program. The NAWQA Program builds upon an existing base of waterquality studies of the USGS, as well as those of other Federal, State, and local agencies. The objectives of the NAWQA Program are to:

- Describe current water-quality conditions for a large part of the Nation's freshwater streams, rivers, and aquifers.

- Describe how water quality is changing over time.

- Improve understanding of the primary natural and human factors that affect water-quality conditions. This information will help support the development and evaluation of management, regulation, and monitoring decisions by other Federal, State, and local agencies to protect, use, and enhance water resources.

The goals of the NAWQA Program are being achieved through ongoing and proposed investigations of 60 of the Nation's most important river basins and aquifer systems, which are referred to as study units. These study units are distributed throughout the Nation and cover a diversity of hydrogeologic settings. More than two-thirds of the Nation's freshwater use occurs within the 60 study units and more than two-thirds of the people served by public water-supply systems live within their boundaries.

National synthesis of data analysis, based on aggregation of comparable information obtained from study units, is a major component of the program. This effort focuses on selected water-quality topics using nationally consistent information. Comparative studies will explain differences and similarities in observed water-quality conditions among study areas and will identify changes and trends and their causes. The first topics addressed by the national synthesis are pesticides, nutrients, volatile organic compounds, and aquatic biology. Discussions on these and other water-quality topics will be published in periodic summaries of the quality of the Nation's ground and surface water as the information becomes available.

This report is an element of the comprehensive body of information developed as part of the NAWQA Program. The program depends heavily on the advice, cooperation, and information from many Federal, State, interstate, Tribal, and local agencies and the public. The assistance and suggestions of all are greatly appreciated. 


\section{CONTENTS}

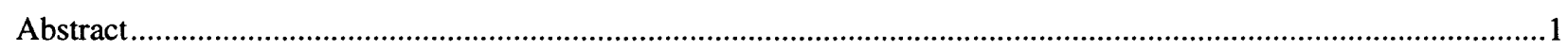

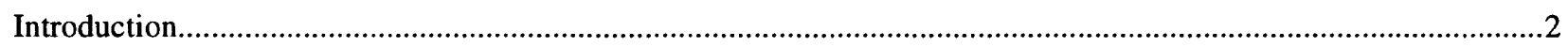

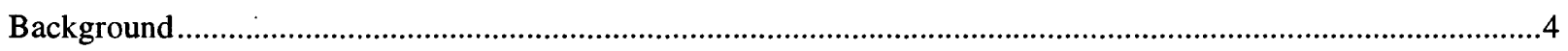

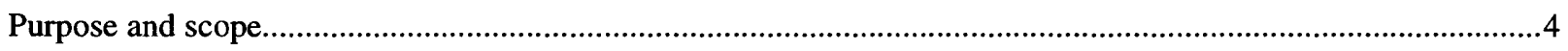

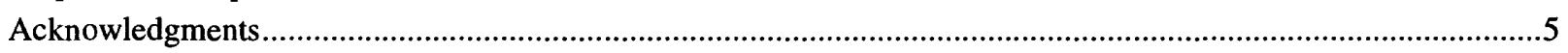

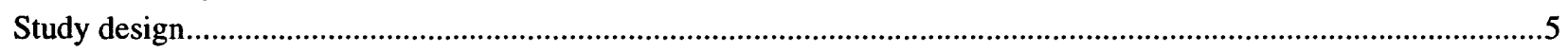

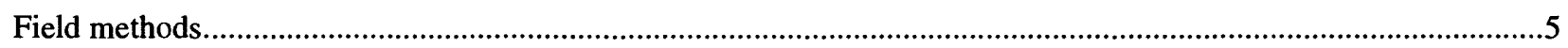

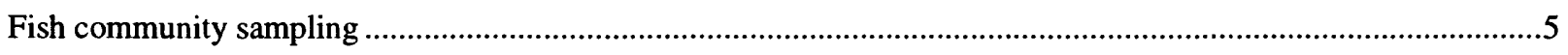

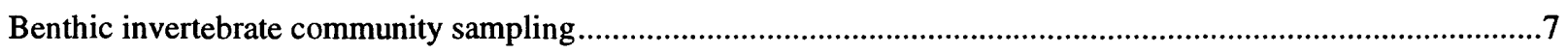

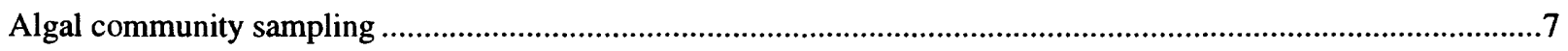

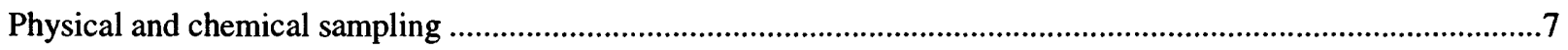

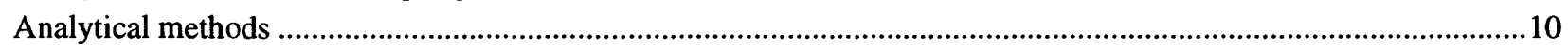

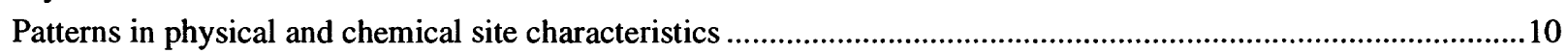

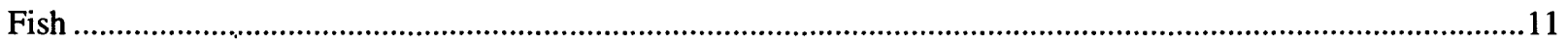

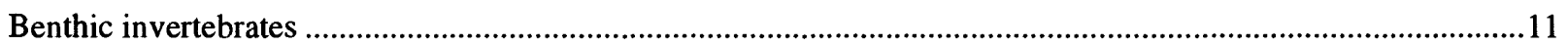

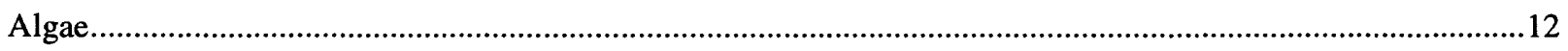

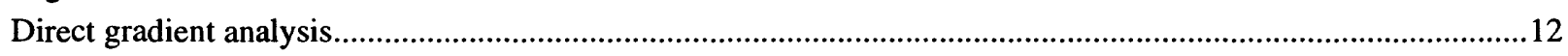

Community metrics and environmental characteristics ..................................................................................

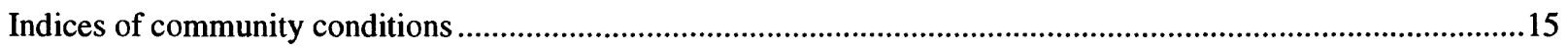

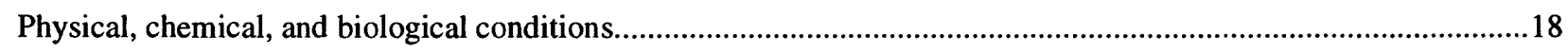

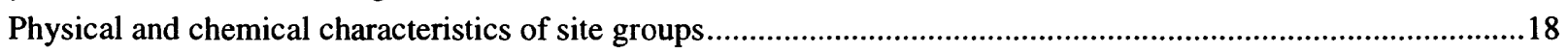

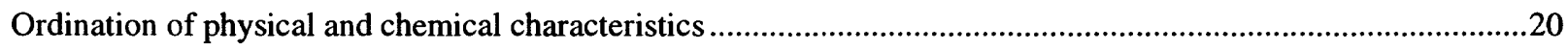

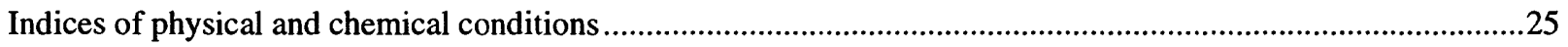

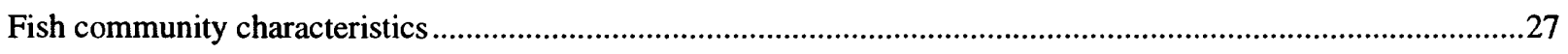

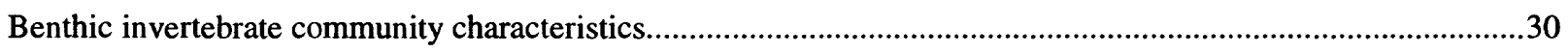

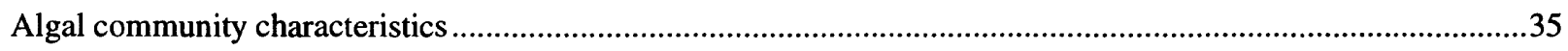

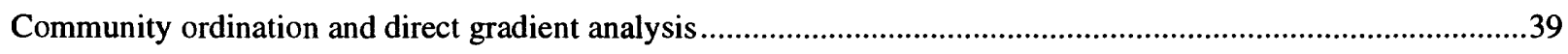

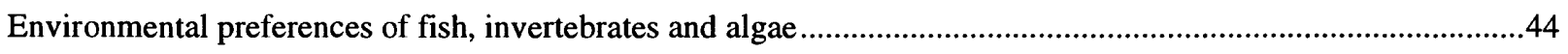

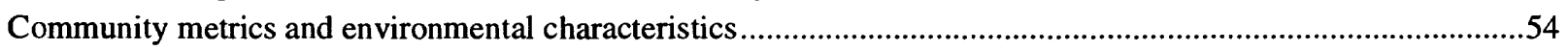

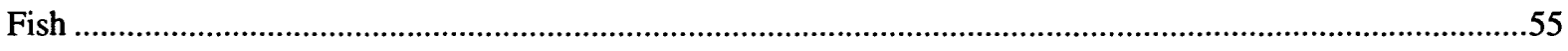

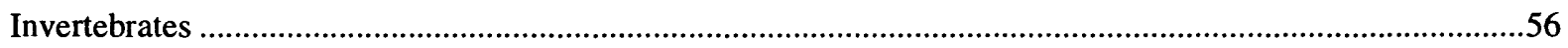

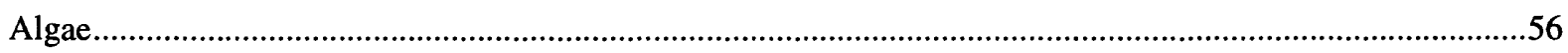

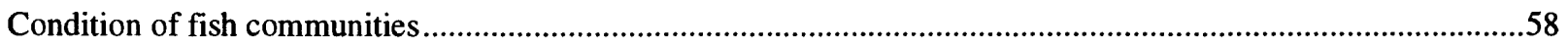

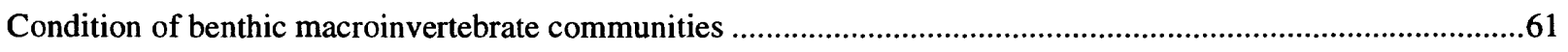

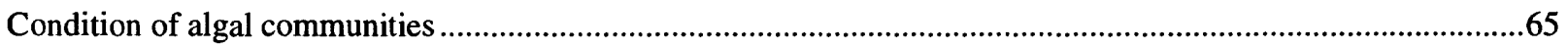

Integrated assessment of site conditions in the Yakima River Basin .................................................................69

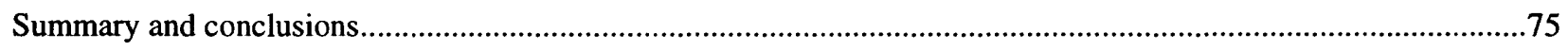

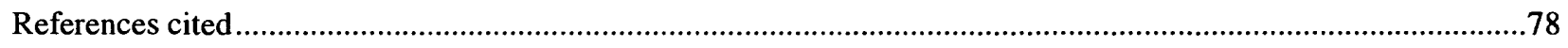

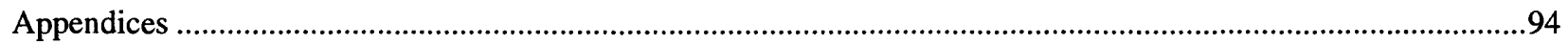

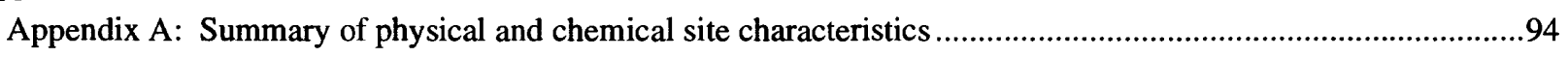

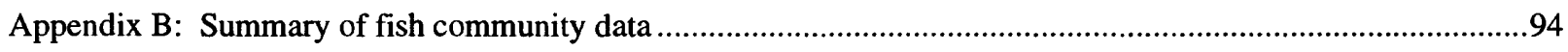

Appendix C: Summary of benthic invertebrate community data ......................................................................94

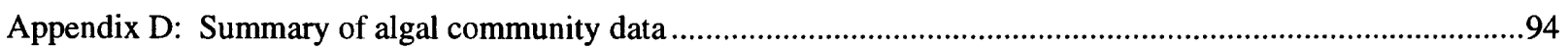




\section{ILLUSTRATIONS}

Figure 1. Locations of fish, benthic invertebrate, algal, habitat, and chemical sampling sites in the Yakima River Basin, Washington, 1990.

2. Percentage of drainage basin area in (A) forest and (B) agriculture, and streamflow originating from (C) forest and (D) irrigated agriculture for sampling sites in the Yakima River Basin, Washington, 1990, summarized by site group.

3. (A) Elevation, (B) canopy closure, (C) substrate size, (D) channel slope, (E) habitat cover, (F) water temperature, $(\mathrm{G})$ substrate embeddedness , and $(\mathrm{H})$ drainage basin area of sampling sites summarized by site group, Yakima River Basin, Washington, 1990.

4. (A) Conductance, (B) total nitrogen, (C) total phosphorus, and (D) suspended organic carbon concentrations in sampling sites summarized by site group, Yakima River Basin, Washington, 1990.

5. Principal components analysis ordination diagram illustrating the relations among sites in the Yakima River Basin, Washington, based on selected environmental variables.

6. Relation between stonefly taxa richness and elevation in the Yakima River Basin, Washington..... 35

7. Algal community composition based on autecological classifications described in the literature..... 38

8. Ordination biplots showing the relations among sites in the Yakima River Basin, Washington, based on

A fish communities

B benthic invertebrate communities

$\mathrm{C}$ algal communities.

9. Relation between fish taxa richness and logarithm of drainage area $\left(\mathrm{km}^{2}\right)$ for sites in the Yakima River Basin, Washington.

10. Relation between percentage of fish community abundance composed of species that are omnivorous or herbivorous and species that are tolerant, Yakima River Basin,

Washington, 1990.

11. Relation between the multimetric fish community condition index and the non-pesticide agricultural intensity (NPAI) index, Yakima River Basin, Washington, 1990.

12. Relation between the multimetric invertebrate community condition index and the nonpesticide agricultural intensity (NPAI) index, Yakima River Basin, Washington, 1990.

13. Algal community composition based on tolerance classifications derived from the correlation of algal abundances with the concentrations of selected nutrients

14. Relation between the multimetric algal community condition index and the non-pesticide agricultural intensity (NPAI) index, Yakima River Basin, Washington, 1990.

15. Summary of site condition rankings indicated by physical, chemical, and biological indices

16. Response of (A) fish, (B) invertebrate, and (C) algal community condition indices to agricultural intensity (non-pesticide agricultural intensity (NPAI) index) in the Columbia Basin site group, Yakima River Basin, Washington, 1990 
17. Map showing site condition ratings based on fish, invertebrate, and algal community condition indices and indices of metals enrichment, agricultural intensity, pesticides contamination, and disturbance.

\section{TABLES}

Table 1. Sites sampled for biology, habitat, and chemistry, Yakima River Basin, Washington, 1990........ 6

2. Environmental variables used to characterize sites in the Yakima River Basin,

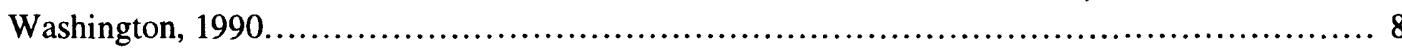

3. Constituents used to calculate pesticide exposure indices.................................. 9

4. Community metrics used in the development of the multimetric community condition index for invertebrates.

5. Common and scientific names of fish species, tolerance, trophic status, and native or introduced status for fish collected in the Yakima River Basin, 1990.

6. Fish community metrics and scoring criteria used to assess biological condition of sites in the Yakima River Basin, Washington, 1990.

7. Qualitative rating classes, scores, and fish community attributes for rating site conditions in the Yakima River Basin, Washington.

8. Summary of site conditions determined from indices that characterize metals enrichment, agricultural intensity (NPAI index), pesticide contamination, and disturbance within the Yakima River Basin, Washington.....

9. Common and scientific names of fish, number of individuals, percentage abundance, and number of sites of occurrence for fish collected from 21 sites in the Yakima River

Basin, October and November 1990

10. Fish taxa richness, abundance, and percentages representing taxonomic groups at each of 21 sites in the Yakima River Basin, Washington, October and November 1990.

11. Invertebrates collected from the Yakima River Basin, Washington, during October 1990, and the number of sites where each taxon was found.

12. Comparison of benthic invertebrate community metrics with those reported by the Washington State Department of Ecology.

13. Community metrics used in the calculation of the multimetric invertebrate community condition index.

14. Invertebrate taxa that differentiate non-agricultural (less than 5 percent of basin area in agriculture) Columbia Basin sites (Satus Creek below Dry Creek, Umtanum Creek, Ahtanum Creek, and Satus Creek at gage) from sites in the Cascades and Eastern Cascades and large-river site groups.

15. Alga taxa, autecological guilds, tolerances, and number of sites where each algal taxon was collected from rocks in the Yakima River Basin, Washington, 1990. 
16. Benthic-algal taxa richness, chlorophyll concentrations, algal cover, abundance, and numerical dominance of autecological guilds in the Yakima Basin, Washington, 1990.

17. Spearman rank correlations (rho) between elevation and other environmental variables used to characterize sites in the Yakima River Basin, Washington, 1990. 45

18. Environmental optima for fish derived from canonical correspondence analysis 46

19. Environmental optima for invertebrates derived from canonical correspondence analysis 48

20. Comparison of invertebrate tolerances derived from canonical correspondence analysis with tolerances determined by Hilsenhoff (1987), Bode (1988), and Wisseman (Mark Munn, U.S. Geological Survey, written commun.,1996).

21. Environmental optima for algae derived from canonical correspondence analysis 53

22. Numbers of taxa in each autecological guild that were correlated indicators of agricultural intensity 57

23. Fish community degradation metrics, community degradation scores, and site impairment ratings, Yakima River Basin, Washington, 1990

24. Spearman rank correlations between indices used to describe physical, chemical, and biological site conditions

\section{CONVERSION FACTORS, ABBREVIATIONS, AND ACRONYMS}

\begin{tabular}{rll}
\hline Multiply & By & To Obtain \\
\hline micrometer $(\mu \mathrm{m})$ & 0.00003937 & inch \\
centimeter $(\mathrm{cm})$ & 0.3937 & inch \\
meter $(\mathrm{m})$ & 3.281 & foot \\
kilometer $(\mathrm{km})$ & 0.6214 & mile \\
square centimeter $\left(\mathrm{cm}^{2}\right)$ & 0.1550 & square inch \\
square meter $\left(\mathrm{m}^{2}\right)$ & 10.76 & square foot \\
hectare $(\mathrm{ha})$ & 2.471 & acre \\
square kilometer $\left(\mathrm{km}^{2}\right)$ & 0.3861 & square mile \\
cubic meter per second $\left(\mathrm{m}^{3} / \mathrm{s}\right)$ & 35.31 & cubic feet per second \\
meters per kilometer $(\mathrm{m} / \mathrm{km})$ & 5.280 & feet per mile \\
centimeters per second $(\mathrm{cm} / \mathrm{s})$ & 0.3937 & inches per second \\
gram $(\mathrm{g})$ & 0.03537 & ounce, avoirdupois \\
liter $(\mathrm{L})$ & 0.2642 & gallon \\
\hline
\end{tabular}

Temperature is given in degrees Celsius $\left({ }^{\circ} \mathrm{C}\right)$, which can be converted to degrees Fahrenheit $\left({ }^{\circ} \mathrm{F}\right)$ by the following equation: ${ }^{\circ} \mathrm{F}=1.8\left({ }^{\circ} \mathrm{C}\right)+32$.

Electrical conductivity is measured as specific electrical conductance in units of microsiemens per centimeter $(\mu \mathrm{S} / \mathrm{cm})$ at 25 degrees Celsius. 


\section{Abbreviations}

$\mathrm{mg} / \mathrm{L}$, milligram per liter $\mu \mathrm{g} / \mathrm{g}$, microgram per gram $\mu \mathrm{g} / \mathrm{L}$, microgram per liter

\section{Acronyms}

AFDM, ash-free dry mass

CANOCO, CANOnical Community Ordination

CCA, canonical correspondence analysis

CPOM, coarse particulate organic matter

EPT, Ephemeroptera, Plecoptera, and Trichoptera

EPTC, S-ethyl dipropylthiocarbamate

$\mathrm{HCB}$, hexachlorobenzene

$\mathrm{HCH}$, hexachlorocyclohexane

IBI, Index of biotic integrity

NAWQA, National Water-Quality Assessment

NPAI, nonpesticide agricultural intensity

NTU, nephelometric turbidity units

PCA, principal components analysis

$\mathrm{QMH}$, qualitative multihabitat

RBP, rapid bioassessment protocol

STORET, USEPA's STOrage and RETrieval system

USEPA, United States Environmental Protection Agency

USGS, United States Geological Survey

WATSTORE, USGS's WATer data STOrage and REtrieval system WSDE, Washington State Department of Ecology 


\title{
DISTRIBUTION OF FISH, BENTHIC INVERTEBRATE, AND ALGAL COMMUNITIES IN RELATION TO PHYSICAL AND CHEMICAL CONDITIONS, YAKIMA RIVER BASIN, WASHINGTON, 1990
}

\author{
By Thomas F. Cuffney, Michael R. Meador, Stephen D. Porter, and Martin E. Gurtz
}

\begin{abstract}
Biological investigations were conducted in the Yakima River Basin, Washington, in conjunction with a pilot study for the U.S. Geological Survey's National Water-Quality Assessment Program. Ecological surveys were conducted at 25 sites in 1990 to (1) assess water-quality conditions based on fish, benthic invertebrate, and algal communities; (2) determine the hydrologic, habitat, and chemical factors that affect the distributions of these organisms; and (3) relate physical and chemical conditions to water quality. Results of these investigations showed that land uses and other associated human activities influenced the biological characteristics of streams and rivers and overall water-quality conditions.
\end{abstract}

Fish communities of headwater streams in the Cascades and Eastern Cascades ecoregions of the Yakima River Basin were primarily composed of salmonids and sculpins, with cyprinids dominating in the rest of the basin. The most common of the 33 fish taxa collected were speckled dace, rainbow trout, and Paiute sculpin. The highest number of taxa (193) was found among the invertebrates. Insects, particularly sensitive forms such as mayflies, stoneflies, and caddisflies (EPT - Ephemeroptera, Plecoptera, and Trichoptera fauna), formed the majority of the invertebrate communities of the Cascades and Eastern Cascades ecoregions. Diatoms dominated algal communities throughout the basin; 134 algal taxa were found on submerged rocks, but other stream microhabitats were not sampled as part of the study. Sensitive red algae and diatoms were predominant in the Cascades and Eastern Cascades ecoregions, whereas the abundance of eutrophic diatoms and green algae was large in the Columbia Basin ecoregion of the Yakima River Basin.

Ordination of physical, chemical, and biological site characteristics indicated that elevation was the dominant factor accounting for the distribution of biota in the Yakima River Basin; agricultural intensity and stream size were of secondary importance. Ordination identified three site groups and three community types. Site groups consisted of (1) small streams of the Cascades and Eastern Cascades ecoregions, (2) small streams of the Columbia Basin ecoregions, and (3) large rivers of the Cascades and Columbia Basin ecoregions. The small streams of the Columbia Basin could be further subdivided into two groups-one where agricultural intensity was low and one where agricultural intensity was moderate to high. Dividing the basin into these three groups removed much of the influence of elevation and facilitated the analysis of land-use effects. Community types identified by ordination were (1) high elevation, cold-water communities associated with low agricultural intensity; (2) lower elevation, warmwater communities associated with low agricultural intensity, and (3) lower elevation, warm-water communities associated with moderate to high agricultural intensity.

Multimetric community condition indices indicated that sites in the Cascades and Eastern Cascades site group were largely unimpaired. In contrast, all but two sites in the Columbia Basin site group were impaired, some severely. Agriculture (nutrients and pesticides) was the primary factor responsible for this impairment, and all impaired sites were characterized by multiple indicators of impairment. Three sites (Granger Drain, Moxee Drain, and Spring Creek) had high levels of impairment. Sites in the large-river site group were moderately to severely impaired downstream from the city of Yakima. High levels of impairment at large-river sites corresponded with high levels of pesticides in fish tissues and the occurrence of external anomalies.

The response exhibited by invertebrates and algae to a gradient of agricultural intensity suggested a threshold response for sites in the Columbia Basin site group. Community condition declined precipitously at agricultural 
intensities above 50 (non-pesticide agricultural intensity index) and showed little response to higher levels of agricultural intensity. This pattern of response suggests that mitigation efforts conducted at sites with high agricultural intensity may not produce meaningful improvement in invertebrate and algal community conditions. In contrast, relatively modest mitigation efforts at sites where the level of agricultural intensity is near to the impairment threshold will probably produce large improvements in community conditions at relatively modest costs. Because the form of the response is critical to effective water-quality management, future cycles of the National WaterQuality Assessment Program should be designed to determine the form of the response that biota exhibit to the major water-quality gradients in a basin.

\section{INTRODUCTION}

The Yakima River Basin is one of the most intensively irrigated areas in the United States, with almost onequarter million hectares under irrigation (fig. 1). About 60 percent of the mean annual streamflow from the basin is diverted for irrigation, drinking water, and power generation. Agricultural return flows, downstream from the city of Yakima, contribute as much as 80 or 90 percent of the flow in the lower main stem during irrigation season (Fuhrer and others, 1996). Intensive use of water for agriculture and for supplies to cities is the primary water-quality issue in the mid to lower Yakima River Valley. Grazing and harvesting of timber are also important water-quality issues, particularly in the Cascades and Eastern Cascades Slopes and Foothills ecoregions. However, grazing and logging are thought to have less effect upon water quality because chemical usage and habitat modifications associated with these land uses are less than those associated with urban land use and irrigated agriculture.

Development in the Yakima River Basin has had severe effects upon biological resources. For example, anadromous fish runs have declined from more than 500,000 adults annually during the 1880's to less than 4,000 adults during the 1980's (Bonneville Power Administration, 1988). Habitat loss, dams, and poor water-quality conditions are the major factors thought to be responsible for the decline of the anadromous fishery in the basin. The presence and accumulation of agricultural chemicals in fish tissue, particularly pesticides such as DDT, are important water-quality and human-health issues in the lower Yakima River (Rinella, McKenzie, Crawford, and others, 1992; Rinella and others, 1993). The effects of agriculture (for example, nutrients, pesticides, and habitat destruction) on aquatic biota are not well documented for benthic invertebrates, algae, and non-game species of fish.

Effective management of surface-water resources in the Yakima River Basin requires the coupling of site status, such as ranking physical, chemical, and biological conditions at impaired sites against reference sites (Ohio Environmental Protection Agency, 1987; Plafkin and others, 1989) with an understanding of how land use changes physical and chemical site characteristics and how biota respond to these changes. Status and an understanding of the factors that control water quality allow managers to identify sites that require attention (status) and take effective action by modifying factors known to control water quality (understanding).

Assessment of the condition of biological communities complements the assessment of chemical conditions by (1) providing a direct measurement of water-quality effects, (2) integrating responses to a variety of environmental exposure pathways, (3) incorporating secondary effects that arise from interactions of populations through competitive and predator-prey interactions, and (4) providing the only approach to water-quality assessment that is sensitive to both toxicological influences and habitat degradation resulting from changes in land use. Integrating physical, chemical, and biological indicators of water-quality conditions reflects the primary objective of the National Clean Water Act, as amended by the Water Quality Act of 1987 (U.S. Government Printing Office, 1988) - to "restore and maintain chemical, physical, and biological integrity of the Nation's waters."

Water-quality status can be derived independently for a variety of chemical and biological constituents by comparing measured chemical concentrations with maximum contaminant limits set by the U.S. Environmental Protection Agency or by comparing biological characteristics with conditions at reference sites (Courtemanch and Davies, 1987; Hilsenhoff, 1987, 1988; Ohio Environmental Protection Agency, 1987; Lenat, 1988). These measurements of water quality provide multiple, sometimes contradictory, lines of evidence for the assessment of status and trends in water-quality conditions. However, water-quality assessment requires more than the identification of status if such assessments are to contribute to scientifically based policy and management decisions. The natural and human factors responsible for producing water-quality conditions must be identified before proper, cost-effective mitigation procedures can be identified, evaluated, and implemented. Identification of these factors 


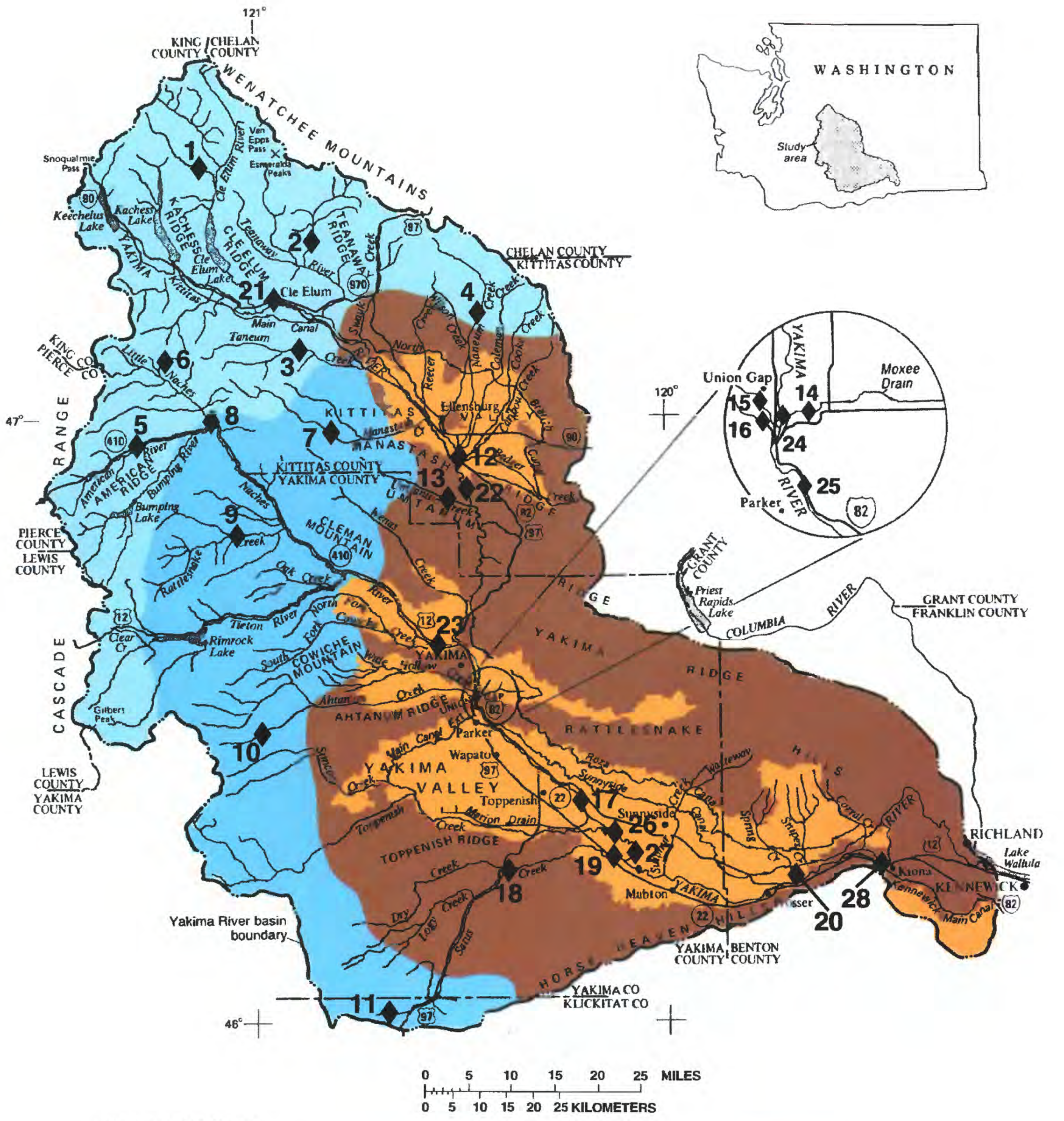

EXPLANATION

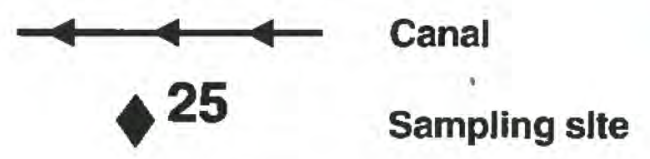

Cascades ecoregion

Columbia BasIn ecoreglon

Eastern Cascades ecoregion

Irrlgated agriculture

Figure 1. Locations of fish, benthic invertebrate, algal, habitat, and chemical sampling sites in the Yakima River Basin, Washington, 1990. (Reference numbers are listed on map and in table 1.) 
requires an approach that integrates physical, chemical, and biological characteristics and that can separate changes along natural gradients from human effects. For example, natural biological changes associated with climate and position on the river continuum (Vannote and others, 1980) must be separated from physical, chemical, and biological changes associated with agricultural practices and intensity. The U.S. Geological Survey's (USGS) National Water-Quality Assessment (NAWQA) Program was established to provide such an approach. This program integrates physical, chemical, and biological information to provide a nationally consistent assessment of the status of and trends in water-quality conditions, and attempts to identify, describe, and explain the major factors that affect observed water-quality conditions and trends (Leahy and others, 1990). Natural and human-related gradients, such as geology and land use, are used in the NAWQA Program to provide a unifying framework for making comparative assessments of water quality within and among hydrologic systems at a wide range of scales and characteristics in different parts of the Nation. This environmental framework is used to compare and contrast findings on water quality in relation to causative factors and to develop inferences about water quality in areas that have not been sampled. Linking assessment of status and trends with an understanding of processes and causes is an element of the NAWQA Program that will enhance our ability to contribute to policies and management actions that improve water quality.

\section{Background}

The NAWQA Program began in 1986 with seven pilot projects (four surface water and three ground water) that were used to develop, test, and refine assessment concepts (Hirsch and others, 1988). Two of these pilot projectsYakima River in Washington and Upper Illinois River Basin in Illinois, Indiana, and Wisconsin-were used to test methods for sampling fish, benthic invertebrate, and algal communities and to develop an integrated approach to physical, chemical, and biological sampling and data analysis. Work in these pilot-study basins resulted in a series of reports (Cuffney and others, 1993a,b; Meador and others, 1993a,b; Porter and others, 1993; Gilliom and others, 1995) that have provided guidance for the design of ecological surveys, sample collection, and sample processing during the national implementation of the NAWQA Program.

The Yakima River Basin pilot study (McKenzie and Rinella, 1987) was conducted from 1987 to 1991, during which data were collected on suspended sediment, nutrients, trace elements, radionuclides, trace organics, bacteria, contaminants in aquatic biota and sediment, and biological communities (Embrey, 1992; Rinella, McKenzie, Crawford, and others, 1992; Rinella, McKenzie, and Fuhrer, 1992; Ryder and others, 1992; Fuhrer, Fluter, and others, 1994; Fuhrer, McKenzie and others, 1994; Fuhrer, Shelley, and others, 1994; Fuhrer and others, 1995). Biological sampling was conducted in 1989 and 1990 and included assessment of fish, algae, and benthic invertebrate community structure as well as instream habitat conditions. These ecological surveys were designed to assess site conditions and identify the important physical and chemical factors that relate to the distribution of organisms in the Yakima River Basin.

\section{Purpose and Scope}

This report documents the results of fish, benthic invertebrate, and algal community sampling conducted as part of the Yakima River Basin pilot study during 1990. It includes a description of sampling techniques; a listing of the fish, benthic invertebrates, and algae collected; a classification of site conditions based on physical, chemical, and biological characteristics; the identification of major natural and human factors that affect the distribution of fish, benthic invertebrates, and algae; and a description of the response of these communities to physical and chemical conditions. These data may be used by scientists and resource managers to quantitatively describe the

(1) spatial distribution of fish, benthic invertebrates, and algae in the Yakima River Basin;

(2) suitability of streams for designated beneficial uses, including aquatic life; and

(3) major natural and human factors that relate to the distribution of fish, benthic invertebrates, and algae.

This report also addresses the relevance of these results to the management of water resources in the Yakima River Basin and suggests future directions for investigations of water quality in the Yakima River Basin during subsequent cycles of the NAWQA Program. 


\section{Acknowledgments}

The authors acknowledge the many individuals who assisted with fish sampling, especially Phil Wampler and Steve Dilley, U.S. Fish and Wildlife Service; Greg Watson and Nick Hindman, Washington Department of Fisheries and Wildlife; Mark Johnston, Ed Comenout, and Joe Pinkum, Yakama Indian Nation; and Scott Edson. Steve Fend, Steve Frenzel, Trae Bradfield, Jim Caldwell, Jim Carter, and Bev Heskiss (USGS) helped with invertebrate and algal sampling. Stu McKenzie, Greg Fuhrer, Joe Rinella, Barbara Scudder, and Harry Leland assisted with water-quality sampling, basin characterization, and reconnaissance and selection of sampling sites. John Kingston, Allison Brigham, and Steve Moulton (USGS Biological Quality-Assurance Unit) reviewed the invertebrate and algal taxonomy. The authors also thank Keith Slack (USGS, retired) who provided guidance and direction for invertebrate sampling during the initial development phases of this project and who designed and built the invertebrate samplers that were later named in his honor.

\section{STUDY DESIGN}

The Yakima River Basin is divided into three natural divisions or ecoregions-Cascades, Eastern Cascades Slopes and Foothills, and the Columbia Basin (Omernik, 1987)-each with distinct physical (climate) and biological characteristics (terrestrial vegetation). Large-river sites in each ecoregion were combined into a separate large-river group because fish, benthic invertebrate, and algal communities of large rivers are known to differ substantially from smaller streams (Vannote and others, 1980). This approach provided four a priori divisions in which to investigate natural and human effects on water quality and biological communities. Dominant land uses (forestry, agriculture, and urban) were used to depict human-engendered factors that modify physical, chemical, and biological conditions within these natural divisions.

Within the three ecoregions, 5 sites were sampled in the Eastern Cascades Slopes and Foothills (in this report, hereafter referred to as Eastern Cascades) ecoregion, 6 were sampled in the Cascades ecoregion, and 14 sites were sampled in the Columbia Basin ecoregion (table 1). Seven of the Columbia Basin sites (Yakima River at Umtanum, Naches River at North Yakima, Yakima River above Ahtanum Creek, Yakima River at Parker, Yakima River below Toppenish, Yakima River at RM 72, and Yakima River at Kiona) and one of the Cascades sites (Yakima River at Cle Elum) formed the large-river site group. These sites constituted a subset of the sites sampled to characterize chemical conditions in the basin (McKenzie and Rinella, 1987; Embrey, 1992; Rinella, McKenzie, Crawford, and others, 1992; Rinella, McKenzie, and Fuhrer, 1992; Ryder and others, 1992; Fuhrer, Fluter and others, 1994; Fuhrer, McKenzie, and others, 1994; Fuhrer, Shelly, and others, 1994; Fuhrer and others, 1995).

\section{FIELD METHODS}

A combination of qualitative and quantitative methods was used to collect representative samples of fish, benthic invertebrate, and algal communities. Algal and invertebrate sampling were done concurrently at each site, whereas fish sampling was done several weeks after the completion of invertebrate and algal sampling. All sampling was restricted to the months of October and November to coincide with the low flows of the post-irrigation season and to ensure that sampling was completed before the onset of winter.

\section{Fish Community Sampling}

Twenty-two of the 25 ecological sites (table 1 ) were sampled to assess fish community structure. Seventeen sites were located on tributaries of the Yakima River and were wadable (less than or equal to one meter deep) whereas five sites were located in the mainstem of the Yakima River (large-river sites, table 1) and were not wadable. Fish were collected by backpack electrofishing at wadable sites and by boat electrofishing at non-wadable sites, following the procedures of Meador and others (1993a). 
Table 1. Sites sampled for biology, habitat, and chemistry, Yakima River Basin, Washington, 1990

[The USGS station number can be used for computer retrieval of chemical data from either the U.S. Geological Survey's WATer data STOrage and REtrieval system (WATSTORE) or the U.S. Environmental Protection Agency's STOrage and RETrieval system (STORET); see figure 1 for location of sampling sites in basin. R, river; Cr, creek; No, North; blw, below; Fk, Fork; X, sampled;-, not sampled; S, sampling suspended due to the presence of spawning salmon.]

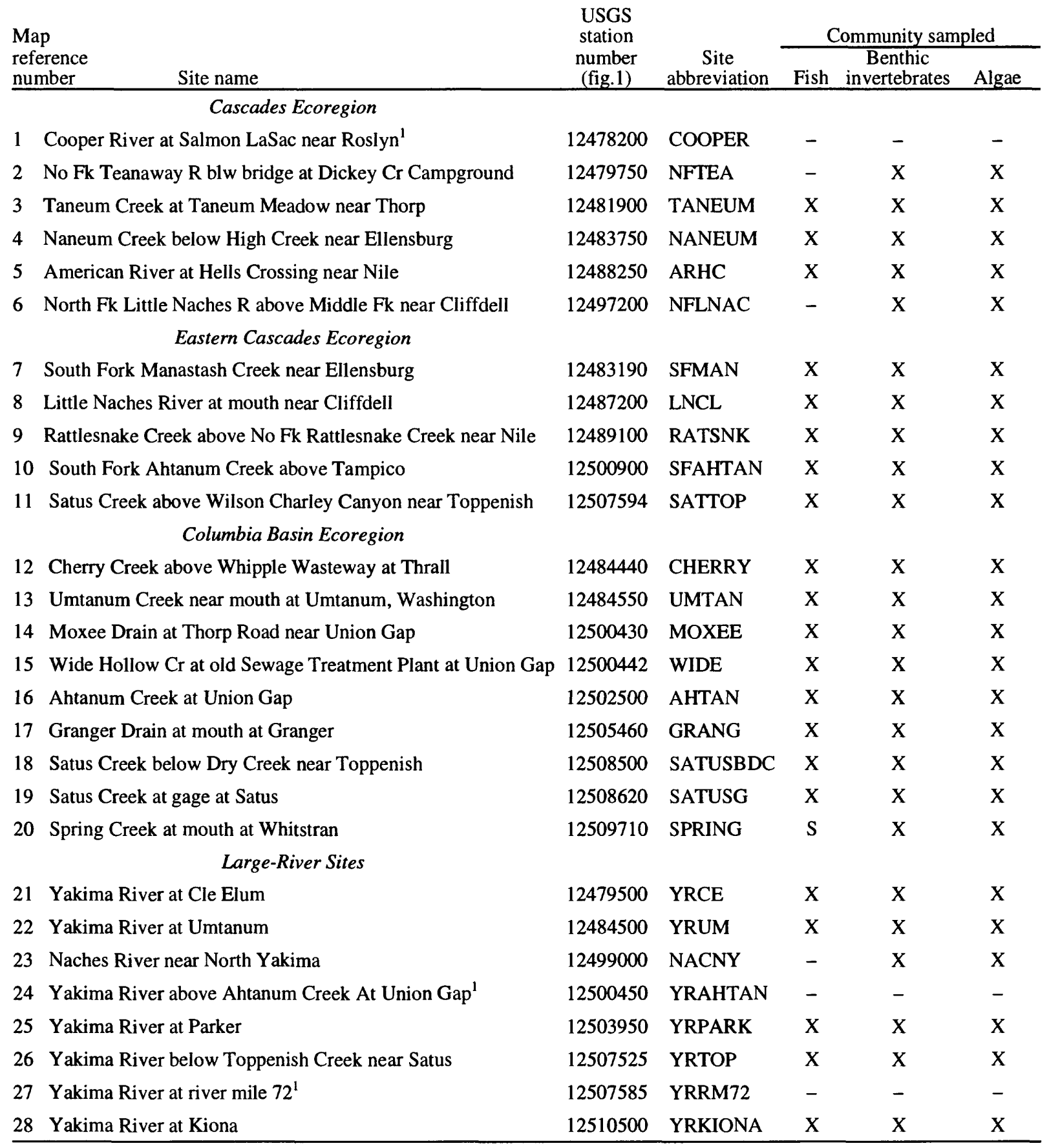

\footnotetext{
${ }^{1}$ Biological communities were not sampled at Cooper River, Yakima River above Ahtanum Creek at Union Gap, and Yakima River at river mile 72. These sites were used to represent the concentration of pesticides in filtered water and suspended sediment at sites in the Cascades and Eastern Cascades ecoregions (Cooper River), Yakima River at Parker (Yakima River above Ahtanum Creek), and Yakima River at Toppenish Creek (Yakima River at river mile 72).
} 
An attempt was made to taxonomically identify as many fish in the field as possible and to return fish to the water unharmed. Fish that were difficult to identify in the field were sacrificed and fixed in 10-percent buffered formalin and preserved in 70-percent isopropyl alcohol for later identification in the laboratory. Taxonomic identification of fish was based on characteristics described by Wydoski and Whitney (1979) and followed scientific names provided by Robins and others (1991). Fish were identified by Phil Wampler (U.S. Fish and Wildlife Service, Olympia, Washington), Greg Watson (Washington Department of Fisheries and Wildlife, Yakima), and Scott Edson (consultant, Leavenworth, Washington). In addition, verification of taxonomic identifications of selected fishes was conducted by Richard Whitney, professor ret. (see Wydoski and Whitney, 1979).

Sample processing of fish included collection of information on the presence of external anomalies. External anomalies are defined as visible skin or subcutaneous disorders, or parasites (Meador and others, 1993a). External anomalies include deformities, eroded fins, lesions, tumors, diseases, and parasites. Selected samples of up to 30 fish per species were examined for the presence of external anomalies.

Of the fish species that occur in Washington, sculpins are the most difficult to identify to species (Wydoski and Whitney, 1979). Whereas some individuals can be identified easily to species, others display intergrading characteristics of two species. In this study, an attempt was made to identify sculpins to species. However, because some individuals could not be identified to species and because of functional similarities among sculpin species in fish communities, all sculpin species were combined for analysis.

\section{Benthic Invertebrate Community Sampling}

Quantitative and qualitative samples of benthic invertebrates were collected at 25 sampling sites (fig. 1). Five quantitative samples were collected from one riffle at each of 23 sites and from each of five riffles at two sites (Ahtanum and Taneum Creeks) using a 0.25-square meter $\left(\mathrm{m}^{2}\right)$ Slack sampler equipped with a 425-micrometer $(\mu \mathrm{m})$ mesh net (Cuffney and others, 1993a). At each site, qualitative samples were collected from all accessible instream habitats and composited to form a single qualitative multihabitat (QMH) sample. These $\mathrm{QMH}$ samples were collected using a D-frame net equipped with a $210-\mu \mathrm{m}$ mesh net that was supplemented by hand-picking from large substrates. The QMH samples provide a comprehensive estimate of the variety of taxa present at each site but not their abundance. Samples were collected and processed using the procedures described in Cuffney and others (1993a) with the exception that quantitative samples were not composited and samples were preserved with 70percent ethanol rather than with formalin. Sample preservative was replaced with fresh 70-percent ethanol within 24-36 hours. Samples were shipped to a contract laboratory for processing, identification, and enumeration of invertebrates.

\section{Algal Community Sampling}

Quantitative samples of benthic algae (periphyton) were collected at 25 sampling sites. Samples were collected from submerged rocks using the NAWQA SG-92 periphyton sampling protocol (Porter and others, 1993). Five quantitative samples were collected from a single riffle at each sampling site with the exception of Ahtanum Creek where five samples were collected from each of four riffles. Samples were prepared by removing periphyton from a small area (approximately 3 square centimeters $\left(\mathrm{cm}^{2}\right)$ ) on each of five rocks collected in association with each invertebrate sample. The composite of five samples collected within the sampling reach represented an area of approximately $75 \mathrm{~cm}^{2}$. Aliquots were withdrawn from each sample and filtered onto Whatman GF/F glass-fiber filters for determinations of chlorophyll $a$ and $b$. Chlorophyll analyses were conducted by the USGS National Water-Quality Laboratory using high-pressure liquid chromatography methods described by Britton and Greeson (1989). Samples for algal-species identification and enumeration were preserved in the field with 5-percent buffered formalin and shipped to a USGS algal laboratory in Louisville, $\mathrm{Ky}$, for processing. In contrast with invertebrate sampling, QMH algal samples were not collected during this study. Therefore, taxa richness at a site could not be estimated because only one microhabitat in the stream reach was sampled.

\section{Physical and Chemical Sampling}

More than 140 variables (tables 2 and 3) were measured and used to describe the physical, hydrologic, land-use, habitat and chemical characteristics of each site. Site characterization was based on a tiered design that incorporated 
Table 2. Environmental variables used to characterize sites in the Yakima River Basin, Washington, 1990

[Abbreviations are used to identify constituents in subsequent figures and tables. Constituents marked with an asterisk were used in the principal components analysis. Sinuosity is the ratio of the channel length between two points on a channel to the straight-line distance between these points. ${ }^{\circ} \mathrm{C}$, degrees Celsius; NTU, nephelometric turbidity units; $\mu \mathrm{S} / \mathrm{cm}$, microsiemens per centimeter at $25^{\circ} \mathrm{C} ; \mu \mathrm{m}$, micrometer; $\mathrm{cm}$, centimeter; $\mathrm{m}$, meter; $\mathrm{km}$, kilometer; $\mathrm{m}^{3} / \mathrm{s}$, cubic meters per second; $\mu \mathrm{g} / \mathrm{g}$, micrograms per gram; $\mathrm{mg} / \mathrm{L}$, milligrams per lite $\mathrm{mg} / \mathrm{m}^{2}$, milligrams per square meter; $\mathrm{g} / \mathrm{m}^{2}$, grams per square meter; $\mathrm{s}$, second; \%, percentage; $\mathrm{N}$, nitrogen; $\mathrm{P}$, phosphorus; $\mathrm{NO}_{2}$, nitrite; $\mathrm{NO}$ nitrate; $\mathrm{NH}_{4}$, ammonia.]

\begin{tabular}{|c|c|c|c|}
\hline Abbreviatio & Environmental variables & Abbreviation & Environmental variables \\
\hline \multicolumn{2}{|c|}{ Physical site characteristics } & \multicolumn{2}{|c|}{ Land-use characteristics } \\
\hline * ELEV & elevation $(\mathrm{m})$ & FORA & forest ( $\%$ of drainage basin area) \\
\hline * DAREA & drainage area $(\mathbf{k m})$ & AGA & agriculture ( $\%$ of drainage basin area) \\
\hline LEN & length $(\mathbf{k m})$ & RANGA & range land ( $\%$ of drainage basin area) \\
\hline * SLOPE & slope $(\mathrm{m} / \mathrm{km})$ & URBA & urban (\% of drainage basin area) \\
\hline SINUOS & sinuosity $(\mathrm{km} / \mathrm{km})$ & * FORF & forest ( $\%$ of flow originating from) \\
\hline * SEGLEN & segment length $(\mathrm{km})$ & * RANGF & range land ( $\%$ of flow originating fron \\
\hline * VEL & velocity at invertebrate sampling site $(\mathrm{cm} / \mathrm{s})$ & * IRRF & irrigated agriculture (\% of flow from) \\
\hline * CANOPY & canopy closure ( \%) & * URBF & urban (\% of flow originating from) \\
\hline * NEGPHI & substrate size $(-1 *$ median $\mathrm{Phi})$ & UNUSF & unused canal flow (\% of total flow) \\
\hline * EMBED & embeddedness of substrate (\%) & Bed-sediment chemis & \\
\hline * MACROP & macrophyte cover (\%) & $* \mathrm{AL}$ & aluminum $(\%)$ \\
\hline * ALGAE & algae cover $(\%)$ & * AS & $\operatorname{arsenic}(\mu \mathrm{g} / \mathrm{g})$ \\
\hline $\mathrm{COV}$ & cover $(\%)$ & B & boron $(\mu \mathrm{g} / \mathrm{g})$ \\
\hline * CPOM & coarse particulate organic matter cover $(\%)$ & * BA & barium $(\mu \mathrm{g} / \mathrm{g})$ \\
\hline * DEPTH & depth $(\mathrm{cm})$ at invertebrate sampling site & * CA & calcium (\%) \\
\hline WIDE & channel width (m) & * CE & cerium $(\mu \mathrm{g} / \mathrm{g})$ \\
\hline MAXD & maximum depth in reach $(\mathrm{cm})$ & * $\mathrm{CO}$ & cobalt $(\mu \mathrm{g} / \mathrm{g})$ \\
\hline TEMP & water temperature at time of collection $\left({ }^{\circ} \mathrm{C}\right)$ & * CR & chromium $(\mu \mathrm{g} / \mathrm{g})$ \\
\hline \multicolumn{2}{|c|}{ Discharge and water-column chemistry } & $* \mathrm{CU}$ & copper $(\mu \mathrm{g} / \mathrm{g})$ \\
\hline $\mathrm{Q}$ & discharge $\left(\mathrm{m}^{3} / \mathrm{s}\right)$ & * FE & iron $(\%)$ \\
\hline * TURB & turbidity (NTU) & * GA & gallium $(\mu \mathrm{g} / \mathrm{g})$ \\
\hline * COND & specific conductance $(\mu \mathrm{S} / \mathrm{cm})$ & * HG & mercury $(\mu \mathrm{g} / \mathrm{g})$ \\
\hline * $\mathrm{PH}$ & $\mathrm{pH}$ (standard units) & $* \mathrm{~K}$ & potassium (\%) \\
\hline * TN & total nitrogen $(\mathrm{mg} / \mathrm{L}$ as $\mathrm{N})$ & * LA & lanthanum $(\mu \mathrm{g} / \mathrm{g})$ \\
\hline * DNH4 & dissolved $\mathrm{NH}_{4}(\mathrm{mg} / \mathrm{L}$ as $\mathrm{N})$ & * LI & lithium $(\mu \mathrm{g} / \mathrm{g})$ \\
\hline * TNH4O & total $\mathrm{NH}_{4}+\operatorname{organic} \mathrm{N}(\mathrm{mg} / \mathrm{L}$ as $\mathrm{N})$ & * MG & magnesium $(\mu \mathrm{g} / \mathrm{g})$ \\
\hline * DNO23 & dissolved $\mathrm{NO}_{2}$ and $\mathrm{NO}_{3}(\mathrm{mg} / \mathrm{L}$ as $\mathrm{N})$ & * $\mathrm{MN}$ & manganese $(\mu \mathrm{g} / \mathrm{g})$ \\
\hline * TP & total phosphorus ( $\mathrm{mg} / \mathrm{L}$ as $\mathrm{P}$ ) & * NA & sodium $(\%)$ \\
\hline * DOP & dissolved ortho-phosphate ( $\mathrm{mg} / \mathrm{L}$ as $\mathrm{P}$ ) & * NI & nickel $(\mu \mathrm{g} / \mathrm{g})$ \\
\hline * SOCP & suspended organic carbon $(\%)$ & * PB & lead $(\mu \mathrm{g} / \mathrm{g})$ \\
\hline SOCMGL & suspended organic carbon ( $\mathrm{mg} / \mathrm{L}$ as $\mathrm{C})$ & * $\mathrm{P}$ & phosphorus (\%) \\
\hline ALK & alkalinity (mg/L) & * SC & scandium $(\mu \mathrm{g} / \mathrm{g})$ \\
\hline HARD & total hardness $(\mathrm{mg} / \mathrm{L})$ & * SN & $\operatorname{tin}(\mu \mathrm{g} / \mathrm{g})$ \\
\hline AFDM & ash-free dry mass of algae $\left(\mathrm{g} / \mathrm{m}^{2}\right)$ & * SR & strontium $(\mu \mathrm{g} / \mathrm{g})$ \\
\hline * CHLA & chlorophyll a $\left(\mathrm{mg} / \mathrm{m}^{2}\right)$ & * TIP & titanium $(\mu \mathrm{g} / \mathrm{g})$ \\
\hline * CHLB & chlorophyll b (mg/m²) & * TOC & total organic carbon $(\%)$ \\
\hline DOC & dissolved organic carbon (mg/L as $\mathrm{C}$ ) & V & vanadium $(\mu \mathrm{g} / \mathrm{g})$ \\
\hline DCA & dissolved calcium $(\mathrm{mg} / \mathrm{L})$ & $* \mathrm{ZN}$ & $\operatorname{zinc}(\mu \mathrm{g} / \mathrm{g})$ \\
\hline DCL & dissolved chloride (mg/L) & & \\
\hline SO4 & dissolved sulfate $(\mathrm{mg} / \mathrm{L})$ & & \\
\hline TDS & total dissolved solids $(\mathrm{mg} / \mathrm{L})$ & & \\
\hline
\end{tabular}


Table 3. Constituents used to calculate pesticide exposure indices

\begin{tabular}{lllll}
\hline & Filtered water & Suspended sediment & Bed sediment & Fish tissue \\
\hline HCB & Heptachlor epoxide & Aldrin & Aldrin & cis-chlordane \\
Triadimefon & o,p'-Methoxychlor & p,p'-DDD & total Chlordane & trans-chlordane \\
Bromacil & p,p'-Methoxychlor & p,p'-DDE & Dieldrin & Oxy-chlordane \\
EPTC & Mirex & p,p'-DDT & p,p'-DDD & Heptachlor epoxide \\
Vernolate & Perthane & DDD+DDE+DDT & p,p'-DDE & cis-Nonachlor \\
Alachlor & Carbofuran & Dieldrin & p,p'-DDT & trans-Nonachlor \\
Atrazine & cis-Permethrin & Endosulfan I & Endosulfan I & o,p'-DDD \\
Deethylatrazine & trans-Permethrin & Endrin & Endrin & p,p'-DDD \\
Butachlor & Propargite & Lindane & Heptachlor & o,p'-DDE \\
Cyanazine & Chlorpyrifos & Heptachlor epoxide & Heptachlor epoxide & p,p'-DDE \\
Metolachlor & Demeton-S & p,p'-Methoxychlor & Lindane & o,p'-DDT \\
Prometon & Diazinon & Mirex & p,p'-Methoxychlor & p,p'-DDT \\
Propazine & Dimethoate & Heptachlor & Mirex & Hexachlorobenzene \\
Simazine & Disulfoton & Chlorpyrifos & & a-Hexachlorocyclohexane \\
Trifluralin & Ethion & Diazinon & & b-Hexachlorocyclohexane \\
Aldrin & Fonofos & Disulfoton & & d-Hexachlorocyclohexane \\
cis-Chlordane & Isofenphos & Ethion & & Lindane \\
trans-Chlordane & Malathion & Malathion & & Toxaphene \\
p,p'-DDE & Methidathion & Methyl parathion & & Dieldrin \\
DDT+DDE+DDD & Methyl parathion & Methyl trithion & & Endrin \\
Dieldrin & Methyl trithion & Parathion & & Mirex \\
Endosulfan I & Mevinphos & Phorate & & \\
Endosulfan II & Parathion & Trithion & & \\
Endrin & Phorate & & & \\
a-HCH & Phosphamidon & & & \\
Lindane & Trithion & & & \\
\hline
\end{tabular}

information at basin, stream-segment, stream-reach, and site levels (Meador and others, 1993b). Basin-level data included drainage area, stream length, land use, and ecoregions. Stream segments were defined as that part of the stream bounded by tributary junctions or major discontinuities, such as waterfalls, landform features, significant changes in gradient, or point-source discharges. Segment-level data included slope, segment length, and sinuosity. The stream reach was that part of the stream where stream, bank, and flood-plain features were representative of the stream segment and close to or at the location where chemical data were collected from the water column and streambed sediment. Stream-reach habitat characterizations included data on elevation, velocity, canopy cover, macrophyte cover, algal cover, habitat cover, wetted channel width, discharge, turbidity, conductance, $\mathrm{pH}$, and temperature. Site-level data included measurements of substrate size, embeddedness of substrate, water depth, and water velocity made in association with each invertebrate sample.

Percentage of canopy cover was measured using the Solar Pathfinder (Solar Pathways, Glenwood Springs, Colorado). A viewing box and ruler were used to visually estimate the percentage of boulders, cobbles, pebbles, gravel, sand, and silt associated with each invertebrate sample. The composition percentage of these substrate classes was then converted to a Phi scale (Hynes, 1970). Embeddedness was estimated by removing representative examples of cobble substrate and measuring the percentage of the rock's depth that was buried in the substrate. Macrophyte, algal, and coarse-particulate organic-matter (CPOM) cover were determined by visual estimation. Habitat cover was determined by measuring the area of the stream reach that was covered by debris dams, overhanging vegetation, and undercut banks. This value was then converted to a percentage of the total area of the stream reach. Physical site characteristics not explicitly described here were collected according to methods presented by Meador and others (1993b). 
Hydrologic and chemical characteristics were measured using standard USGS techniques (Ryder and others, 1992, Rinella, McKenzie, Crawford, and others, 1992; Fuhrer, Fluter, and others, 1994; Fuhrer, Shelley, and others, 1994). Pesticide data for filtered water, suspended sediment, bed sediment, and fish tissue were obtained from a basin-wide synoptic sampling conducted during June of 1989 (Rinella, McKenzie, Crawford, and others, 1992). Concentration data for major and minor elements in bed sediment were obtained from a compilation of data collected from 1987 to 1991 (Ryder and others, 1992; Fuhrer, Shelley, and others, 1994). Land use was characterized on the basis of basin area and streamflow associated with forest, irrigated agriculture, rangeland and dry land farming, and urban sources. Data on other environmental variables (for example, nutrients, turbidity, conductivity, and $\mathrm{pH}$ ) are averages of measurements made during August and September 1990.

\section{ANALYTICAL METHODS}

Patterns in physical and chemical characteristics of the four $a$ priori site groups (three ecoregions and large rivers) were summarized using box plots and indices that characterize metals enrichment, agricultural intensity, pesticide contamination, and overall disturbance. Site groupings-obtained by separate ordinations of (1) physical and chemical site characteristics, (2) fish, (3) invertebrate, and (4) algal communities-were used to determine if the $a$ priori site groups provided a meaningful classification of sampling sites. Direct gradient analysis (canonical correspondence analysis; ter Braak, 1987-1992) was used to determine how the biota responded to major natural and human-engendered gradients in the basin. Stepwise regression and Spearman rank correlation were used to investigate the relation between environmental factors and community characteristics (metrics) commonly used in the development of multimetric indices of community condition. Multimetric indices of community condition were used to determine whether the condition of fish, invertebrate, and algal communities indicated high, moderate, or low impairment. Indices of metals enrichment, agricultural intensity, and pesticide contamination were also used to rank the level of concern at a site based on physical and chemical characteristics.

\section{Patterns in Physical and Chemical Site Characteristics}

Differences among a priori site groups (three ecoregions and large rivers) were examined graphically by using box plots. Principal components analysis (PCA) (Jongman and others, 1987) was used to examine site groupings based on 77 environmental variables (table 2) that were measured at the 25 sampling sites. Data that were not already expressed as percentages were standardized by dividing all values for a constituent by the maximum value of that constituent and then multiplying the result by 100 . The resulting values (range: $0-100$ ) were converted to an octave scale (Gauch, 1982) prior to conducting the PCA. This transformation standardizes measurements made using widely differing units (for example, elevation in meters and chemical concentrations in micrograms per liter $(\mu \mathrm{g} / \mathrm{L}))$ and prevents data with a large absolute range (for example, basin area) from overwhelming the analysis. Censored data were not used in these analyses.

Indices were developed to characterize the relative magnitude of metals contamination, non-pesticide agricultural intensity (NPAI), and pesticide contamination in filtered water, suspended sediment, and bed sediment. These indices were calculated for each site using the following equation:

$$
\begin{aligned}
& \mathbf{N} \\
& \text { Index }=\quad \Sigma\left(\mathrm{X}_{\mathrm{i}} / \mathrm{X}_{\mathrm{i}} \min \right) / \mathrm{N} \\
& \mathrm{i}=1 \\
& \text { where } \mathrm{N} \text { is the number of constituents that compose the index, } \\
& \mathrm{X}_{\mathrm{i}} \quad \text { is the value of one of } \mathrm{N} \text { constituents that compose the index, and } \\
& \mathrm{X}_{\mathrm{i}} \min \quad \text { is the minimum value of constituent } \mathrm{X}_{\mathrm{i}} \text { observed across the } 25 \text { sampling sites. }
\end{aligned}
$$

Therefore, these indices represent multiples of the background (minimum) concentrations. The metals index was restricted to metals typically associated with human activities (copper, chromium, mercury, nickel, zinc, and lead in bed sediment). The NPAI index included turbidity, conductivity, substrate embeddedness, and nutrients (total nitrogen, dissolved ammonia, total ammonia plus organic nitrogen, dissolved nitrite plus nitrate, total phosphorus, and dissolved ortho-phosphate). Separate indices were calculated for pesticides in filtered water (52 constituents), 
suspended sediment (23 constituents), and bed sediment (13 constituents) (table 3). Pesticide data from nearby sites were used to represent two sites in the Columbia Basin: Yakima River at Parker was represented by Yakima River above Ahtanum Creek at Union Gap (station number 12500450, fig. 1), and Yakima River at Toppenish was represented by Yakima River at RM 72 (station number 12507585, fig. 1). Cooper River (12478200, fig. 1), a small stream in the Cascades ecoregion, was used to substitute for missing pesticide data in filtered water and suspended sediment for sites in the Cascades and Eastern Cascades ecoregions. Pesticides that were not encountered at concentrations above detection limits or that were collected only at a subset of the biological sampling sites were excluded from the indices. Measurements that were determined to be below detection limits were set to one-half of the reported detection limit since these measurements actually lie somewhere between zero and the detection limit. This approach produces estimates that are less biased than would result from setting values to the detection limit, which is the maximum possible value.

An index of pesticides in fish tissue was calculated for each site by using the mean concentrations of pesticides measured in several species of fish. Each tissue sample consisted of a composite of several individuals of a single species (Rinella, McKenzie, Crawford, and others, 1992). The index was calculated based on the mean pesticide concentrations for all samples at a site (multiple species), and concentrations were not normalized for differences in lipid content. The value of the index for each sample is the sum of the concentrations of each detected compound divided by its detection level. Any sample that had no detections was arbitrarily assigned a value of 0.05 , which approximated background levels.

An index of disturbance was calculated from the metals, NPAI, and pesticide (filtered water, suspended sediment, and fish tissue) indices. The average of the fish tissue pesticide index for sites in the Cascades and Eastern Cascades was used to fill in missing data for North Fork Little Naches River and South Fork Ahtanum Creek. Pesticides in bed sediment could not be used in the disturbance index because data were missing for sites where concentrations were expected to be appreciably above background levels. The disturbance index was calculated for each site by averaging the five indices (metals, NPAI, and pesticides in filtered water, suspended sediment, and fish tissue) and then dividing the average for each site by the maximum average observed over all sites. This approach gives equal weighting to each of the five indices.

\section{Fish}

Fish community data were summarized based on fish taxa richness, total numbers of individuals, and taxonomic compositions based on major family groups. Fish community structure was characterized by using four community metrics (percent composition of tolerant individuals, non-native individuals, omnivores/herbivores, and individuals with external anomalies) that have been commonly incorporated as part of the index of biotic integrity (IBI) (Simon and Lyons, 1995). Direct gradient analysis was used to identify how fish responded to the major physical, chemical, and land-use gradients in the basin. Multiple regression and Spearman rank correlation were used to determine relations between fish community metrics and physical and chemical site characteristics. Multimetric procedures were used to determine community condition.

\section{Benthic Invertebrates}

Mean abundance was calculated for each benthic invertebrate taxon based on the five quantitative samples collected at each site. Only the first riffles sampled at Ahtanum and Taneum Creeks were used in the analysis of factors controlling the distribution of invertebrates and the assessment of site conditions. This was done to maintain consistency in sampling effort among sites. Results from qualitative multihabitat samples were combined with the quantitative samples to develop a list of taxa residing at each site (taxa richness).

Ambiguous taxa were removed from the samples-by-species data matrix to avoid overestimating taxa richness and diversity as a result of problems associated with identifying invertebrates. Ambiguous taxa occur when the parent (next highest taxonomic level) of a taxon exists in the data matrix. This happens most frequently when members of a genus cannot be identified to species at one or more sites because they are either too immature or damaged. The ambiguity is typically resolved by combining the children (species) with the parent (genus) for all sites. Occasionally the parent may be extremely rare in the data set, but the children may be very abundant. In this case, the parent would be dropped or its abundance distributed among the children. If the ambiguity involved a 
single genus and species, the genus was elevated to the species level; this had no effect on the data analyses but preserved the maximum taxonomic information. The process of resolving ambiguous taxa is analogous to establishing detection limits for chemical analyses. The resulting data set provides consistency in the level of identification for all sites and increases the validity of intersite comparisons. The list of taxa collected from the Yakima River Basin was reviewed by the USGS Biological Quality-Assurance Unit (Cuffney and others, 1993b) to ensure that the nomenclature was current and accurate.

Invertebrate community data were summarized based on 59 community metrics (for example, taxa richness, total number of individuals, number of taxa and abundance of mayflies, stoneflies, caddisflies) (table 4) that have been used or proposed for use in multimetric indices of community condition (Ohio Environmental Protection Agency, 1987; Lenat, 1988; Plafkin and others, 1989). Direct gradient analysis was used to determine how invertebrates responded to the major physical, chemical, and land-use gradients in the basin. Multiple regression and Spearman rank correlation were used to determine the relation between invertebrate community metrics and physical and chemical factors. Multimetric procedures were used to determine community condition.

\section{Algae}

Algal community data were summarized based on the abundance and water-quality tolerance classifications of species and community characteristics. Average abundance was calculated for each taxon from the five quantitative periphyton samples collected from each stream reach. Algal community data were summarized based on autecological characteristics and an assessment of the tolerance of algae to agricultural disturbance. Direct gradient analysis was used to determine how algae responded to major physical, chemical, and land-use gradients in the basin. Spearman-rank correlation was used to explore relations between algal abundance and biological, chemical, and physical conditions. Algae were assigned to autecological guilds based on published literature. Community condition was determined by converting tolerance derived from correlation with nutrients into a multimetric condition index that was ranked against appropriate reference sites.

\section{Direct Gradient Analysis}

The relations between organism distributions and physical and chemical site conditions were examined by using direct gradient analysis. Direct gradient analysis is an ordination technique that attempts to explain the species responses by extracting theoretical environmental gradients (ordination axes) that are constrained to be linear combinations of environmental variables specified by the investigator. Canonical correspondence analysis (CANOCO; ter Braak, 1985) was used to conduct the direct gradient analyses, which determines the major axes of variability in the community data (theoretical environmental gradients) and positions sites in ordination space so that sites with similar communities are grouped together, and sites with dissimilar communities are far apart. Unlike PCA, the underlying response model for canonical correspondence analysis (CCA) is unimodal rather than linear. The unimodal response model more closely approximates biological responses in which an organism's abundance increases to a maximum and then declines as an environmental parameter increases. The value of the environmental parameter at which maximum abundance is achieved is the species optimum, and the width of the unimodal curve indicates the species tolerance.

Organism abundances were log-transformed ( $\mathrm{n}[\mathrm{X}+1]$ for fish, invertebrates, and algae) (Gauch, 1982) prior to the correspondence analysis. Only common taxa (fish at two or more sites; invertebrates and algae at five or more sites) were considered in the analysis. Physical and chemical site variables were also log-transformed $(\ln [\mathrm{X}+0.001])$ to normalize the data prior to performing the CCA. The environmental variables used to represent major gradients in the basin were derived from the PCA of physical and chemical factors and from the indices of pesticide contamination. Related environmental variables (for example, nutrients) were combined into a single index because CCA analysis requires that the number of environmental variables must be less than the number of sites or the ordination will not be constrained by the environmental variables. 
Table 4. Community metrics used in the development of the multimetric community condition index for invertebrates

[The 20 metrics listed in bold type were used to calculate the multimetric community condition index. These metrics were significantly correlated with the disturbance index and showed $a \geq 50$ percent contrast between reference and impaired sites in the Columbia Basin. Metrics marked with an asterisk are the eight metrics used in the unmodified RBP III index (Plafkin and others, 1989).]

Taxa richness

Taxonomic groupings:

* Total taxa richness: number of different kinds of organisms

* EPT richness: number of mayfly (Ephemeroptera), stonefly (Plecoptera), and caddisfly (Trichoptera) taxa

Proportion of total taxa richness composed of EPT taxa

Number of mayfly taxa

Proportion of total taxa richness composed of mayfly taxa

Number of stonefly taxa

Proportion of total taxa richness composed of stonefly taxa

Number of caddisfly taxa

Proportion of total taxa richness composed of caddisfly taxa

Number of midge taxa

Proportion of total taxa richness composed of midge taxa

* Community loss index (Courtemanch and Davies, 1987): measures loss of taxa between a reference station and the station of comparison

Functional groupings:

Number of shredder taxa

Proportion of total taxa richness composed of shredder taxa

Number of scraper taxa

Proportion of total taxa richness composed of scraper taxa

Number of collector-gatherer taxa

Proportion of total taxa richness composed of collector-gatherer taxa

Number of collector-filterer taxa

Proportion of total taxa richness composed of collector-filterer taxa

Number of predator taxa

Tolerance

Proportion of total taxa richness composed of predator taxa

Proportion of total taxa richness composed of taxa tolerant to agriculture (NPAI)

Proportion of total taxa richness composed of taxa intolerant to agriculture (NPAI)

Abundance

Taxonomic groupings

Total abundance

EPT Abundance: abundance of mayfly (Ephemeroptera), stonefly (Plecoptera), and caddisfly (Trichoptera) taxa

Proportion of total abundance composed of EPT taxa

Abundance of mayfly taxa

Proportion of total abundance composed of mayfly taxa

Abundance of stonefly taxa

Proportion of total abundance composed of stonefly taxa

Abundance of caddisfly taxa

Proportion of total abundance composed of caddisfly taxa

Abundance of midge taxa

Proportion of total abundance composed of midge taxa

* Ratio of EPT and chironomid abundances 
Table 4. Community metrics used in the development of the multimetric community condition index for invertebrates-Continued

Abundance (continued)
Functional groupings

Abundance of shredder taxa

Proportion of total abundance composed of shredder taxa

Abundance of scraper taxa

Proportion of total abundance composed of scraper taxa

Abundance of collector-gatherer taxa

Proportion of total abundance composed of collector-gatherer taxa

Abundance of collector-filterer taxa

Proportion of total abundance composed of collector-filterer taxa

Abundance of predator taxa

Proportion of total abundance composed of predator taxa

* Ratio of scraper abundance to collector-filterer abundance

* Ratio of shredder abundance to total abundance

Dominance

Abundance of the dominant taxon

* Proportion of total abundance composed of the dominant taxon

Abundance of the two most dominant taxa

Proportion of total abundance composed of the two most dominant taxa

Abundance of the five most dominant taxa

Proportion of total abundance composed of the five most dominant taxa

Tolerance

Family Biotic Index (Hilsenhoff 1988)

Mean tolerance to NPAI

Proportion of total abundance composed of taxa tolerant to agriculture (NPAI)

Proportion of total abundance composed of taxa intolerant to agriculture (NPAI)

* Hilsenhoff Biotic Index (modified): combines organism abundance and tolerance information to produce an index that increases as water quality decreases. The index has been modified to include non-arthropod taxa.

\section{Community Metrics and Environmental Characteristics}

Stepwise multiple regression and Spearman-rank correlation were used to examine the relation between physical and chemical site characteristics and fish, invertebrate, and algal community metrics (for example, taxa richness) commonly used to describe communities. The procedure REG (SAS Institute, Inc., 1988) was used to summarize the relations between combinations of physical and chemical factors and community metrics. These relations were compared to results obtained by direct gradient analysis and were used to help interpret how community metrics used in the calculating indices of community condition respond to physical and chemical changes.

Pairwise correlation analysis was used to examine the relations between physical and chemical site characteristics and algal community characteristics. The abundance of selected species or autecological groups was correlated (Spearman-rank correlation) with physical and chemical site characteristics to elucidate physicochemical relations among the algae. Algal autecological guilds used in these analyses were: cosmopolitan-widely distributed species that are tolerant of a large range of environmental conditions; eutrophic-species that are tolerant of high nutrient concentrations; halophilic - species that prefer sites with high dissolved solids; nitrogen fixers-species that are capable of fixing nitrogen and commonly found in nitrogen-poor waters; facultative nitrogen heterotrophs-species that are capable of using reduced nitrogenous compounds as an energy source; oligotrophic and oligothermalspecies that prefer sites with low nutrient concentrations and low temperatures; and siltation tolerant-species capable of surviving in areas with high siltation rates. Autecological classifications or guilds are presented in Lowe (1974); Fairchild and others (1985); and Van Dam and others (1994). 


\section{Indices of Community Conditions}

Biological condition of fish communities was assessed by using a multimetric index rather than the IBI (Karr and others, 1986) because an IBI has not been developed and applied to Washington streams. Four metrics-percentage of individuals as tolerant species, percentage of individuals as non-native species, percentage of individuals as omnivores/herbivores, and percentage of individuals with external anomalies-were used in the multimetric condition index. These metrics were selected because they are similar to metrics used in the IBI (Plafkin and others, 1989) and tend to increase with increasing environmental degradation, an underlying assumption of IBI metrics (Fausch and others, 1990). In this study, the metric representing the percentage of omnivore individuals was broadened to include herbivores. Although herbivores are considered to be specialized feeders whereas omnivores are considered to be generalist, herbivores thrive where sunlight and nutrient conditions are sufficient to sustain plant growth. Thus, the presence of herbivores may be related to streams with open tree canopies and nutrient inputs from agriculture that stimulate the growth of algae.

Fish were characterized according to tolerance, trophic association, and origin (native or introduced) (table 5) based on classifications of Hughes and Gammon (1987) and Chandler and others (1993). Because each of the metrics increases with increasing environmental degradation, each of the four fish community condition metrics were rated as 1 (unimpaired), 3 (moderately impaired), or 5 (severely impaired) (table 6). Scoring criteria for percentages of individuals with external anomalies, omnivores/herbivores, and non-native individuals followed criteria developed for a modified IBI for the Willamette River, Oregon (Hughes and Gammon, 1987). Hughes and Gammon (1987) did not include a category for percentage of tolerant individuals; thus, scoring criteria for this metric followed Bramblett and Fausch (1991). Metric ratings were then summed to yield a numerical score, potentially ranging from 4 to 20, with the highest score indicating a site in degraded condition. Total scores were then used to assign sites to one of three qualitative classes of community impairment: low (4-8), moderate (10-14), and high (16-20) (table 7). Rankings were applied only to those sites where more than one species were collected.

Condition of the benthic macroinvertebrate communities was determined using a multimetric condition index that combines community metrics to produce a contrast between reference and heavily degraded sites. This method involved ranking community metrics (table 4), relative to conditions at appropriate reference (least affected) sites. Reference sites were identified based on a consideration of their biological characteristics (large total richness and EPT richness, which is the number of mayflies, stoneflies, and caddisflies), the sites they grouped with in the ordination (PCA) of the physical and chemical site characteristics, and whether the site showed evidence of impairment based on values of the various physical and chemical indices (metals, NPAI, pesticides, and disturbance). The use of reference sites that are specific to each site group compensates for differences in the value of metrics that arise from differences in natural factors such as climate and elevation. These adjustments help to separate the effects of natural environmental factors from human influences.

The multimetric index of invertebrate community condition was developed from 59 community metrics (table 4) that have been used or proposed for use in rapid bioassessment protocol (RBP)-style community condition indices. An RBP community condition index (Plafkin and others, 1989) was not used because this index has not been modified for use in the Yakima River Basin. Modifications are necessary to ensure the sensitivity and accuracy of the index by adjusting for natural differences in the distribution of organisms within and among areas where natural conditions are relatively homogeneous (for example, ecoregion-specific metrics and metric scores) (Barbour and others, 1996). The State of Washington is currently developing regional biocriteria, but a modified index is not yet available.

The community metrics used in the multimetric index of community condition describe the similarities and differences in the taxonomic, functional feeding group, and tolerance composition of the invertebrate communities. Functional feeding groups are derived from a classification scheme that combines taxa that perform similar functions based on food acquisition mechanisms (Cummins, 1973, 1974; Merritt and Cummins, 1996). Six functional groups were used to summarize community data for the multimetric condition indices: shredders-organisms that feed on large live or dead plant material, collector-filterers-suspension feeders, collector-gatherers-deposit feeders, scrapers-grazers, and predators-organisms that feed on other animals. 
Table 5. Common and scientific names of fish species, tolerance, trophic status, and native or introduced status for fish collected in the Yakima River Basin, 1990

[Data are from Hughes and Gammon (1987), and Chandler and others (1993). Tolerant species are adaptable to environmental degradation resulting from erosion and siltation, organic and inorganic pollution, channelization, and flow fluctuations (Bramblett and Fausch, 1991). Intolerant species are the converse of tolerant and are the first species to decline when streams are degraded by human activity (Karr and others, 1986). Trophic group is based on the diet of adult fish (after Karr and others, 1986): F, filter feeder; I, invertivore ( $>90 \%$ invertebrates); O, omnivore (25-90\% plant-detritus, $10-75 \%$ invertebrates); $\mathrm{H}$, herbivore ( $>90 \%$ plant-detritus, $<10 \%$ invertebrates); and $\mathrm{P}$, piscivore ( $>90 \%$ fish).]

\begin{tabular}{|c|c|c|c|c|}
\hline Common name & Scientific name & Tolerance & $\begin{array}{l}\text { Trophic } \\
\text { group }\end{array}$ & $\begin{array}{l}\text { Native or } \\
\text { introduced }\end{array}$ \\
\hline Lampreys & Petromyzontidae & & & \\
\hline River lamprey & Lampetra ayresi & Intolerant & $\mathrm{F}$ & Native \\
\hline Western brook lamprey & Lampetra richardsoni & Intolerant & $\mathbf{F}$ & Native \\
\hline Minnows and carps & Cyprinidae & & & \\
\hline Chiselmouth & Acrocheilus alutaceus & Tolerant & $\mathbf{H}$ & Native \\
\hline Common carp & Cyprinus carpio & Tolerant & $\mathrm{O}$ & Introduced \\
\hline Northern squawfish. & Ptychocheilus oregonsis & Tolerant & $P$ & Native \\
\hline Longnose dace & Rhinichthys cataractae & Tolerant & I & Native \\
\hline Leopard dace & Rhinichthys falcatus & Tolerant & I & Native \\
\hline Speckled dace & Rhinichthys osculus & Tolerant & I & Native \\
\hline Redside shiner & Richardsonius balteatus & Tolerant & I & Native \\
\hline Suckers & Catostomidae & & & \\
\hline Bridgelip sucker & Catostomus columbianus & Tolerant & $\mathrm{H}$ & Native \\
\hline Largescale sucker & Catostomus macrocheilus & Tolerant & $\mathrm{O}$ & Native \\
\hline Mountain sucker & Catostomus platyrhynchus & Tolerant & $\mathbf{H}$ & Native \\
\hline Salmon and trouts & Salmonidae & & & \\
\hline Coho salmon & Oncorhynchus kisutch & Intolerant & I & Native \\
\hline Chinook salmon & Oncorhynchus tshawytscha & Intolerant & I & Native \\
\hline Cutthroat trout & Oncorhynchus clarki & Intolerant & I & Native \\
\hline Rainbow trout & Oncorhynchus mykiss & Intolerant & I & Native \\
\hline Mountain whitefish & Prosopium williamsoni & Intolerant & I & Native \\
\hline Brown trout & Salmo trutta & Intolerant & I & Introduced \\
\hline Brook trout & Salvelinus fontinalis & Intolerant & I & Introduced \\
\hline Dolly Varden & Salvelinus malma & Intolerant & $\mathbf{P}$ & Native \\
\hline Sticklebacks & Gasterosteidae & & & \\
\hline Three-spine stickleback & Gasterosteus aculeatus & Intolerant & I & Native \\
\hline Sculpins & Cottidae & & & \\
\hline Paiute sculpin & Cottus beldingi & Intolerant & I & Native \\
\hline Slimy sculpin & Cottus cognatus & Intolerant & I & Native \\
\hline Shorthead sculpin & Cottus confusus & Intolerant & I & Native \\
\hline Torrent sculpin & Cottus rhotheus & Intolerant & I & Native \\
\hline Sunfishes & Centrarchidae & & & \\
\hline Pumpkinseed & Lepomis gibbosus & Intolerant & I & Introduced \\
\hline Bluegill & Lepomis macrochirus & Tolerant & I & Introduced \\
\hline Smallmouth bass & Micropterus dolomieu & Intolerant & $P$ & Introduced \\
\hline Largemouth bass & Micropterus salmoides & Intolerant & $\mathrm{P}$ & Introduced \\
\hline
\end{tabular}


Table 6. Fish community metrics and scoring criteria used to assess biological condition of sites in the Yakima River Basin, Washington, 1990

[The scoring criterion is used to add one of three values $(1,3$, or 5$)$ to the index depending upon the value of the metric. A low value indicates low degradation; a high value indicates high degradation. Values for the four metrics are added together to form the condition index.]

\begin{tabular}{llccc}
\hline & & \multicolumn{3}{c}{ Scoring criteria (percent) } \\
\cline { 3 - 5 } & & 1 (low) & 3 (moderate) & 5 (high) \\
\hline 1. & Percentage of individuals as tolerant species & $0-25$ & $26-50$ & $>50$ \\
2. & Percentage of individuals as non-native species & $0-1$ & $2-9$ & $>9$ \\
3. & Percentage of individuals as omnivores/herbivores & $0-24$ & $25-49$ & $>49$ \\
4. & Percentage of individuals with external anomalies & $0-1$ & $2-5$ & $>5$ \\
\hline
\end{tabular}

Table 7. Qualitative rating classes, scores, and fish community attributes for rating site conditions in the Yakima River Basin, Washington

\begin{tabular}{lcl}
\hline Rating class & Scores & \multicolumn{1}{c}{ Fish community attributes } \\
\hline High & $16-20$ & $\begin{array}{l}\text { Fish community is composed largely of species tolerant to physical and chemical } \\
\text { disturbance, dominated by omnivores and non-native species; fish with signs of disease, } \\
\text { parasites, fin damage, and other external anomalies. }\end{array}$ \\
Moderate & $10-14$ & $\begin{array}{l}\text { Indications of community degradation including loss of intolerant species, increasing } \\
\text { frequency of tolerant, omnivore, and non-native individuals. }\end{array}$ \\
Low & $4-8$ & $\begin{array}{l}\text { Fish community includes significant composition of species intolerant to physical or } \\
\text { chemical disturbance, balanced trophic structure, and relatively few non-native species. }\end{array}$ \\
\hline
\end{tabular}

The 59 metrics considered in the construction of the multimetric invertebrate community condition index included the eight metrics (table 4) used by the RBP community condition index (Plafkin and others, 1989). A metric was selected for use in this index if the metric was significantly correlated with disturbance (index of disturbance) and showed a large ( $\geq 50$ percent) contrast between reference and grossly impacted sites in the Columbia Basin ecoregion. Selected metrics were scored against reference sites and summed to obtain the multimetric condition index according to the following equation:

$$
\begin{aligned}
& \text { Multimetric index }=\sum_{i=1}^{n}\left[\left(M_{i} / M_{i} \text { ref }\right) 10\right] / n \\
& \text { where } \quad \begin{array}{ll}
M_{i} & \text { is the value of metric } i, \\
M_{i} \text { ref } & \text { is the value of metric } i \text { at the appropriate reference site, and } \\
n & \text { is the number of metrics comprising the index. }
\end{array}
\end{aligned}
$$

The resulting multimetric community index can range from 0 to 10 where zero indicates a large departure from the reference condition (severely impaired) and 10 indicates conditions equivalent to reference conditions (unimpaired). Four reference sites (Taneum Creek, Rattlesnake Creek, South Fork Manastash Creek, and Satus Creek near Toppenish) were used to represent the Cascades and Eastern Cascades site group, two sites (Satus Creek below Dry Creek and Umtanum Creek) represented the Columbia Basin site group, and two sites (Yakima River at Umtanum 
and Naches River near North Yakima) represented the large-river site group. Sites that had high total and EPT taxa richnesses and low levels of metals, nutrients, and pesticide contamination were used as reference sites.

Impairment thresholds were set so that a site with a condition score that was within 75 percent of reference conditions (index score $\geq 7.5$ ) was considered to be an unimpaired site and $\leq 25$ percent (index scores $\leq 2.5$ ) was considered to be a severely impaired site. Sites with intermediate scores were considered to be moderately impaired. The community condition score developed for invertebrates differs from that used to characterize fish communities in that low scores indicate impairment and high scores indicate reference conditions. A mean condition index and 95 percent confidence interval were calculated and used to characterize the variability of the community condition estimate.

The condition of benthic-algal communities in the Yakima River Basin were determined by categorizing taxa as tolerant, intolerant, or moderately tolerant depending upon the correlation between abundance and nutrient concentrations. A taxon that had a significant positive correlation with forms of nitrogen or phosphorus (table 2) was categorized as tolerant; a significant negative correlation was categorized as intolerant, and a non-significant correlation was categorized as cosmopolitan. A site score was calculated by multiplying the relative abundance of tolerant taxa by 1 , cosmopolitan taxa by 5 , and intolerant taxa by 10 and then summing the scores to produce a site score that could vary from 1 (all tolerant taxa indicating a severely impaired site) to 10 (all intolerant taxa indicating an unimpaired site). This site score was adjusted by subtracting a value of 1 and dividing by the score of an appropriate reference site to produce an estimate of the algal community condition index that ranged from 0 (severely impaired) to 1 (unimpaired).

Four reference sites (Taneum Creek, Rattlesnake Creek, South Fork Manastash Creek, and Satus Creek near Toppenish) were used for the Cascades and Eastern Cascades site group, two sites (Satus Creek below Dry Creek and Umtanum Creek) for the Columbia Basin site group, and two sites (Yakima River at Umtanum and Naches River near North Yakima) for the large-river site group. These are the same reference sites that were used for determining the condition of sites based on invertebrate community structure. These sites have rich communities of algae and invertebrates, large abundances of intolerant forms, and low levels of metals, nutrients, and pesticide contamination. The community condition score developed for algae differs from that used to characterize fish communities in that low scores indicate impairment and high scores indicate reference conditions. A mean condition index and 95 percent confidence interval were calculated and used to characterize the variability of the community condition estimate based on multiple reference sites.

\section{PHYSICAL, CHEMICAL, AND BIOLOGICAL CONDITIONS}

The Yakima River Basin is composed of three ecoregions: Cascades, Eastern Cascades Slopes and Foothills (Eastern Cascades), and Columbia Basin (fig. 1). Each of these ecoregions represents a unique combination of landscape features that produce a distinctive terrestrial vegetation and climate. Because the distribution of lotic organisms is linked to conditions in the surrounding terrestrial ecosystem (Hynes, 1975) and to stream size (Vannote and others, 1980), sites in the Yakima River Basin were expected to form four natural groupings-three ecoregions and large rivers- that can be compared and contrasted in order to understand the natural and human-induced factors that affect biological distributions and water quality (table 1).

\section{Physical and Chemical Characteristics of Site Groups}

Land use was very similar in the Cascades and Eastern Cascades ecoregions but differed markedly in the Columbia Basin ecoregion. Silviculture was the dominant land use in the Cascades ecoregion and a combination of silviculture and grazing was the dominant land use in the Eastern Cascades ecoregion (fig. $2 \mathrm{~A}$ and B). Agriculture was the dominant land use in the Columbia Basin ecoregion (fig. 2, C and D). Land use in the large-river site group was a mixture of forest and irrigated agriculture (fig. 2, B and D) with a small amount of urban influence $(<3$ percent). The land-use characteristics associated with each site group were consistent regardless of whether land use was expressed as a proportion of basin area (fig. $2 \mathrm{~A}$ and $\mathrm{C}$ ) or origin of stream flow (fig. $2 \mathrm{~B}$ and D). Land use for large river sites was available only on the basis of flow. 

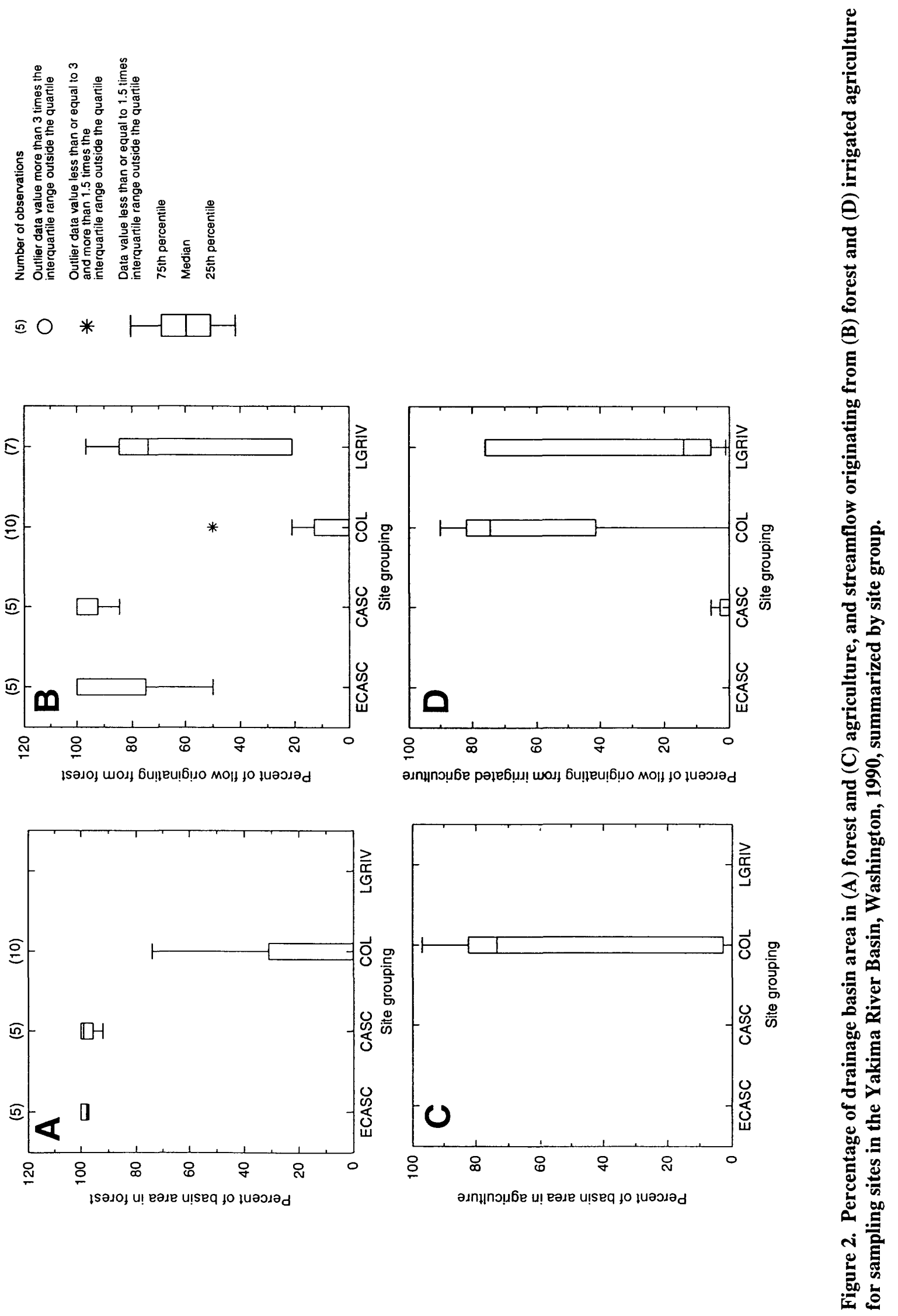
Among the physical site characteristics (fig. 3), elevation (A), canopy closure (B), substrate size (C), channel slope (D), and habitat cover (E) were similar in the Cascades and Eastern Cascades ecoregions and much greater than in the Columbia Basin ecoregion. Water temperature $(F)$ and substrate embeddedness $(G)$ were higher in the Columbia Basin than in the Cascades and Eastern Cascades ecoregions. The Columbia Basin and large-river site groups tended to have similar site characteristics except for drainage basin area $(\mathrm{H})$ which, as expected, is much larger for the large-river sites, and canopy closure (B) and channel slope (D) which tend to be smaller and less variable for the large-river site group. Patterns in physical site characteristics corresponded to the differences observed in land use. Streams in the Cascades and Eastern Cascades ecoregions tended to be physically similar and were higher, colder, had larger substrates, more habitat cover, and greater slopes than did streams of the Columbia Basin and large-river site groups where most of the intensive agriculture is located.

The effects of agricultural activities were evident in the pattern exhibited by selected chemical parameters (fig. 4). Specific conductance (A) and concentrations of nutrients (B and C) were low in the Cascades and Eastern Cascades ecoregions, high in the Columbia Basin site group, and intermediate in the large-river site group. The intermediate values associated with large rivers arise when nutrient-enriched water from agricultural return flows (Cherry Creek, Moxee Drain, Granger Drain, and Spring Creek) mix with low-nutrient water from the Cascades and Eastern Cascades (Appendix A). Suspended organic carbon (SOC) also showed effects associated with agriculture. The percentage of SOC was higher in the Cascades and Eastern Cascades site groups than in the Columbia and largeriver site groups (D), but the median concentration of SOC was lowest in the Cascades and Eastern Cascades ( 0.1 $\mathrm{mg} / \mathrm{L}$ each $)$, highest in the large-river site group $(0.3 \mathrm{mg} / \mathrm{L})$, and intermediate in the Columbia site group $(0.2 \mathrm{mg} / \mathrm{L})$ (Appendix A). This difference indicates that the high level of agriculture in the Columbia Basin results in an increase in the amount of inorganic material (sediment) in suspension, which lowers the relative proportion of organic carbon in suspension. This is evident at Granger and Moxee Drains, two agricultural drains that are characterized by the highest SOC concentrations $(2.4$ and $1.7 \mathrm{mg} / \mathrm{L}$, respectively), the lowest proportion of suspended SOC in the Yakima Basin ( 0.40 and 0.48 percent, respectively), and the highest turbidities (19 and 49.7 nephelometric turbidity units (NTU), respectively) of any of the 25 sites sampled (Appendix A).

Concentrations of metals in bed sediment tended to be variable and generally did not show patterns that related to land use, site group, or ecoregion. Instead, enrichment was related to geological sources in the Kittitas and Mid Valley areas (Fuhrer, Fluter, and others, 1994; Leland, 1995; Fuhrer and others, 1995). Concentrations of antimony, arsenic, chromium, copper, mercury, nickel, selenium, and zinc were enriched in the Cle Elum, Upper Naches, Teanaway, and Tieton subbasins. Concentrations of metals in other streams of the Cascades and Eastern Cascades ecoregions and in the Columbia Basin ecoregion were generally low. Physical and chemical site characteristics are available in digital format (Appendix A).

\section{Ordination of Physical and Chemical Characteristics}

Ordination (PCA) of the physical and chemical site characteristics underscored the similarities between sites in the Cascades and Eastern Cascades ecoregions and the differences between those sites and sites in the Columbia Basin and large-river site groups (fig. 5). PCA is an ordination technique that reduces the complex structure of the physical and chemical data to a two-dimensional plot in which sites located near one another have similar characteristics and those located far apart have dissimilar characteristics. Columbia Basin sites tended to group in the upper-right quadrant, Cascades and Eastern Cascades sites grouped in the upper-left quadrant, and large-river sites grouped in the lower-right quadrant. However, two Columbia Basin ecoregion sites (Umtanum Creek and Satus Creek below Dry Creek) grouped with the Cascades and Eastern Cascades sites indicating that the physical and chemical conditions at these two sites are more similar to conditions in the Cascades and Eastern Cascades than to other sites in the Columbia Basin. These two sites are relatively unaffected by agriculture $(<5$ percent of basin area and 0 percent of streamflow) in contrast to the other Columbia Basin sites that are heavily affected by irrigated agriculture ( $>70$ percent of flow originating from irrigated agriculture). Because Umtanum Creek and Satus Creek below Dry Creek are relatively unaffected by agriculture and group with the relatively unimpaired streams of the Cascades and Eastern Cascades, they are candidates for use as Columbia Basin reference sites in the determination of community conditions. Yakima River at Cle Elum showed similarities with sites in the Cascades ecoregion and with large-river sites of the Columbia Basin ecoregion. 

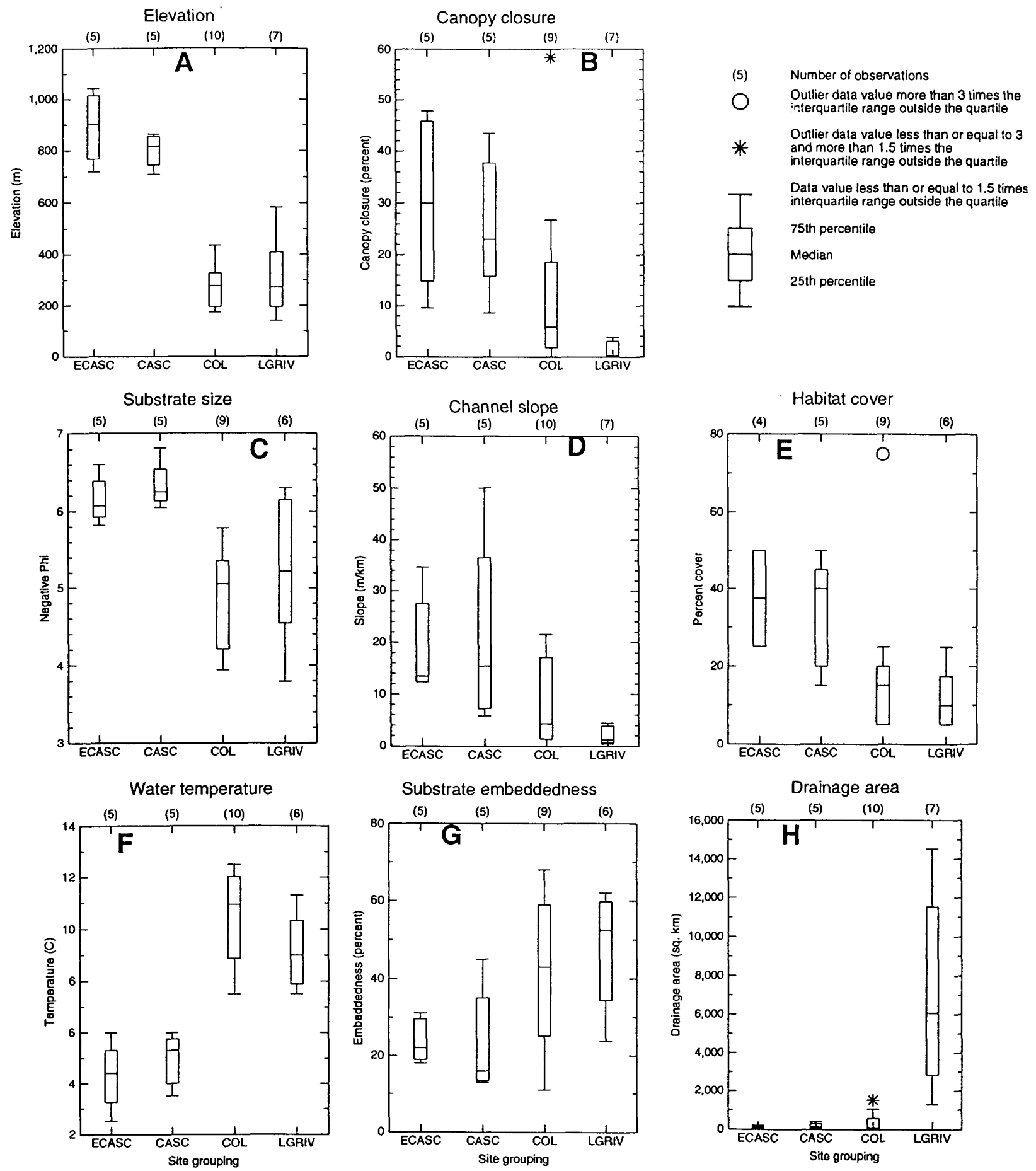

Figure 3. (A) Elevation, (B) canopy closure, (C) substrate size, (D) channel slope, (E) habitat cover, (F) water temperature, (G) substrate embeddedness, and (H) drainage basin area of sampling sites summarized by site group, Yakima River Basin, Washington, 1990. 

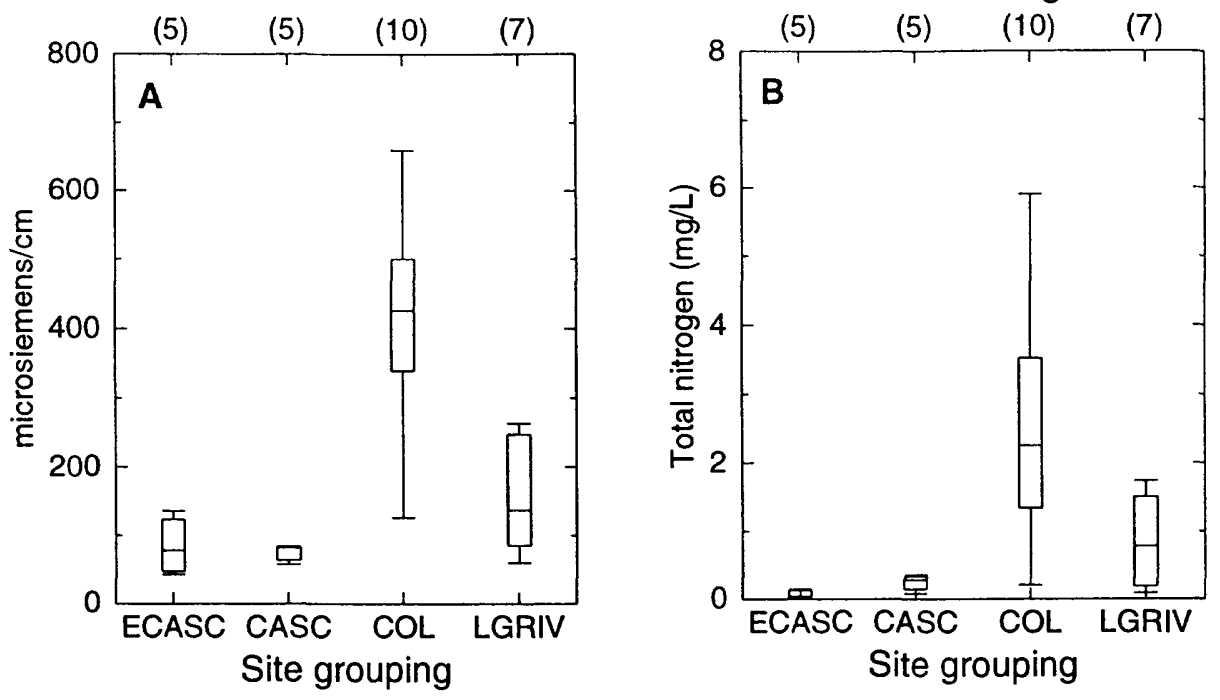

Total phosphorus

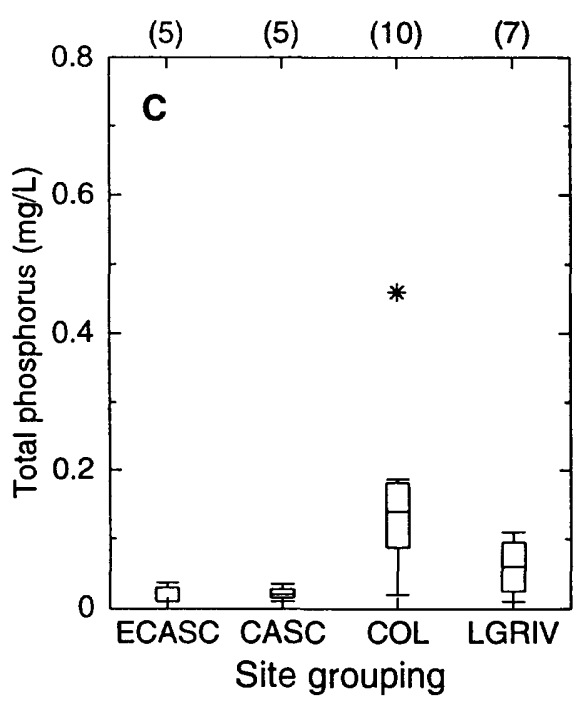

Suspended organic carbon

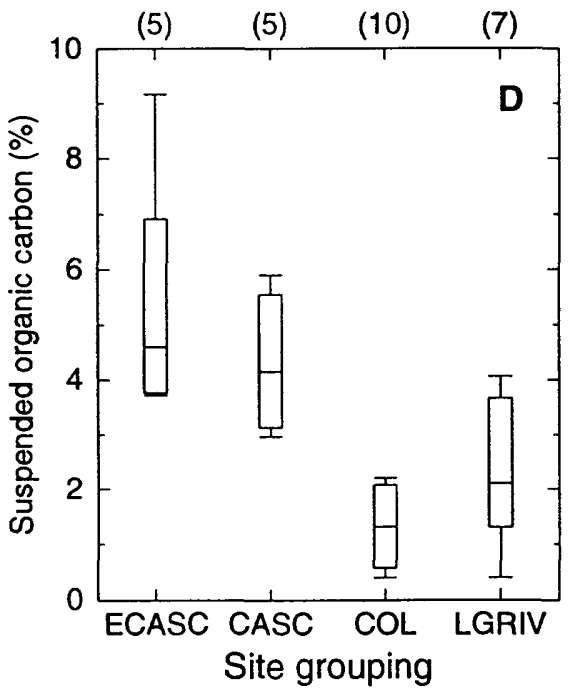

Number of observations
Outlier data value more than 3 times the
interquartile range outside the quartile

Figure 4. (A) Conductance, (B) total nitrogen, (C) total phosphorus, and (D) suspended organic carbon concentrations in sampling sites summarized by site group, Yakima River Basin, Washington, 1990. 
Site groupings:

口 Cascades

- Eastern Cascades

- Columbia Basin

O Large River

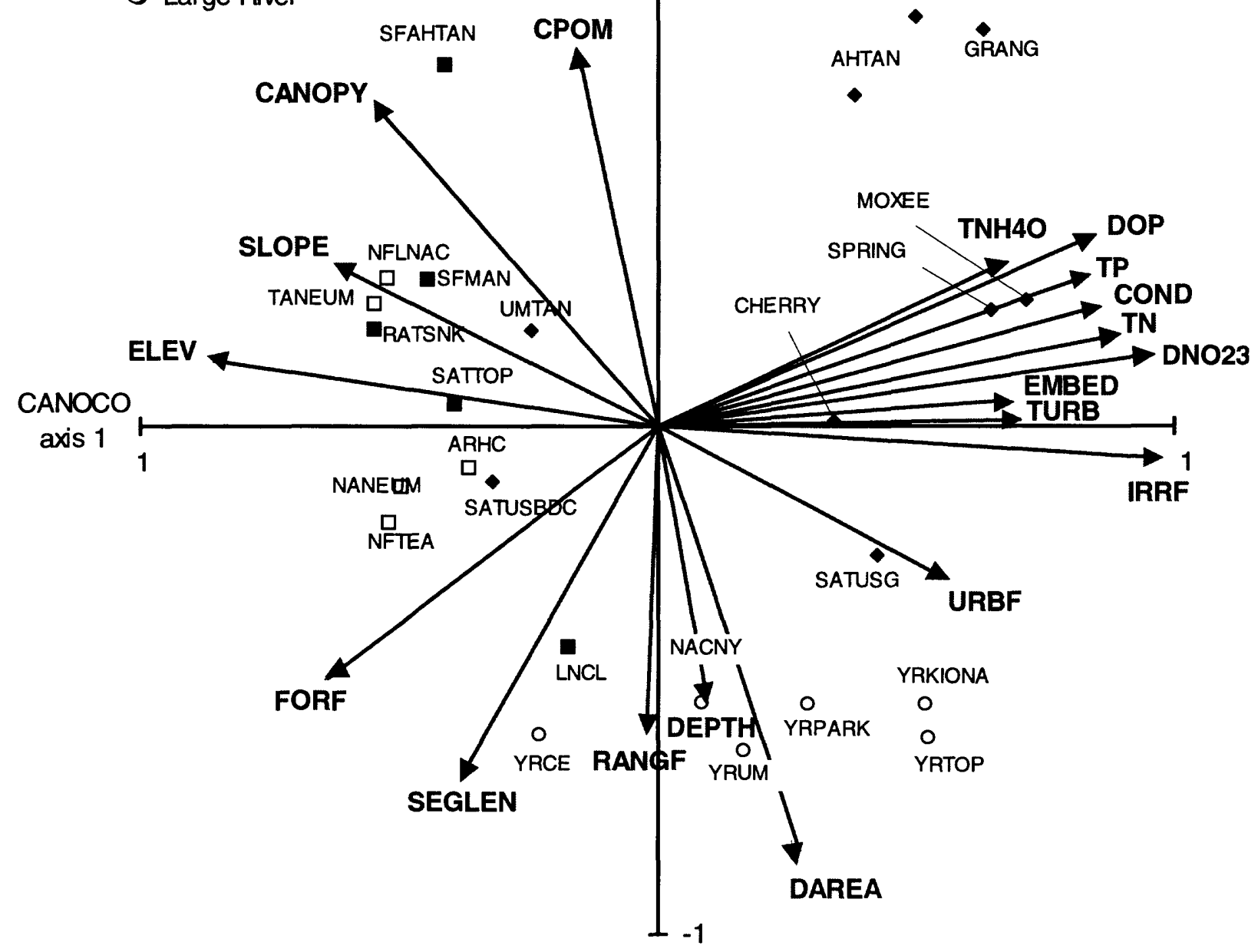

CANOCO axis 2

Figure 5. Principal components analysis ordination diagram illustrating the relations among sites in the Yakima River Basin, Washington, based on selected environmental variables. (Arrows in the ordination diagram represent environmental variables for which at least 60 percent of the variability was accounted for by the ordination axes. Abbreviations for site names are listed in table 1. Abbreviations for environmental variables are listed in table 2.) 
The Cascades and Eastern Cascades sites formed a single group in the ordination indicating that, on the basis of physical and chemical site characteristics, these sites are indistinguishable. This result is supported by the graphs of physical and chemical site characteristics (figs. 2-4), which showed little difference between the Cascades and Eastern Cascades ecoregions. This result suggests that sites from these ecoregions should be combined for analysis and that biological communities will probably be similar.

Ordination axes are linear combinations of the physical and chemical characteristics that maximize the amount of variability explained by the axes. Therefore, the ordination axes represent theoretical environmental gradients derived from the physical and chemical characteristics of the sites. The lengths of the arrows used to represent individual physical and chemical characteristics indicate their importance to the ordination, with importance increasing as length increases. Nutrients (dissolved ortho-phosphate, DOP; total phosphorus, TP; total nitrogen, TN; dissolved nitrite + nitrate, DNO23), amount of irrigation return flow (IRRF), and elevation (ELEV) are characterized by longer arrows and have, therefore, a greater influence on separating sites than does percentage of flow originating from range land (RANGF), streamflow originating from urban areas (URBF), and water depth (DEPTH), which have shorter arrows.

The arrows point in the direction in which the value of the corresponding physical or chemical characteristic increases across the ordination diagram. Arrows represent an axis for each characteristic that extends across the ordination diagrams though only the positive portion of the axis is indicated in the diagram. The fitted value of each characteristic can be determined by projecting each site onto the axis (arrow) that represents each characteristic. For example, projecting sites onto the arrow that represents elevation reveals that the fitted values for the Cascades and Eastern Cascades sites are much higher than those of the Columbia Basin and large-river sites. The fitted value for elevation at South Fork Manastash Creek is higher than the mean for all sites because the point projected from the site to the axis lies on the same side of the origin as the head of the arrow. Conversely, Moxee Drain (MOXEE) is less than the mean because it lies on the opposite side of the origin.

Arrows that point in the same direction indicate positively correlated constituents; perpendicular arrows are uncorrelated, and arrows pointing in opposite directions are negatively correlated. The ordination indicates that nutrients, embeddedness, and irrigation return flows are all highly correlated because the arrows that represent these variables lie close to one another. Conversely, coarse-particulate organic matter (CPOM) and the amount of flow arising from rangelands (RANGF) have a low correlation with nutrients because the arrows depicting these variables are nearly perpendicular to the arrows depicting nutrients. Elevation has a strong negative correlation with nutrients because the arrow representing elevation is roughly parallel to the arrow representing nutrients but its head is on the opposite side of the origin.

The major gradients in the ordination relate to elevation and land use (low-elevation, agriculturally affected streams on the right as opposed to relatively unaffected, high-elevation streams on the left) on the first ordination (x) axis and stream size (smaller streams at the top, larger streams at the bottom) on the second ordination (y) axis. The effects of agriculture are indicated by nutrients (dissolved ortho-phosphate, DOP; total phosphorus, TP; total nitrogen, TN; ammonia and organic total nitrogen, TNH4O; dissolved nitrite and nitrate, DNO23), conductivity (COND), turbidity (TURB), substrate embeddedness (EMBED), and the percentage of streamflow originating from irrigated agriculture (IRRF). Stream size is indicated by drainage basin area (DAREA) and stream depth (DEPTH). Agricultural factors have a high positive correlation with the first ordination axis. In contrast, the relatively unaffected streams of the Cascades and Eastern Cascades show a negative correlation with agricultural characteristics. These relatively unaffected sites are characterized by higher elevation (ELEV), streamflows that originated in forests (FORF), larger stream slope (SLOPE), and a greater degree of canopy closure (CANOPY) than is associated with the agriculturally affected sites. Drainage basin area (DAREA) and stream depth (DEPTH) are positively correlated with the second ordination axis.

Agriculturally unimpaired sites are composed of sites located in the Cascades and Eastern Cascades ecoregions, one large-river site (Yakima River at Cle Elum), and two Columbia Basin sites (Umtanum Creek and Satus Creek below Dry Creek). The agriculturally affected sites are composed of Columbia Basin sites (except Umtanum Creek and Satus Creek below Dry Creek) and large-river sites located downstream from the Yakima River at Cle Elum. Umtanum Creek and Satus Creek below Dry Creek group with the relatively unaffected Cascades and Eastern Cascades sites, which makes them candidates for use as reference sites in multimetric analyses and may indicate that 
Columbia Basin streams were much more similar to at least some of the lower-elevation streams in the Cascades and Eastern Cascades prior to the development of extensive irrigated agriculture.

\section{Indices of Physical and Chemical Conditions}

Physical and chemical site conditions were summarized using indices of metals enrichment, agricultural intensity, pesticide contamination, and disturbance (table 8) that classified site conditions as high, moderate, or low impairment. Criteria for assignment to a condition class were based on the index range, the distribution of index values, and biological conditions. For example, the range of the metals index was modest (from 1.4 to 9.6), and only modest biological effects (for example, slightly reduced taxa richness) were associated with high values of the metals index. Therefore, it was decided that the maximum metals index represented only a moderate level of effect (moderate impairment). In contrast, the index of agricultural intensity (NPAI index) and pesticide indices exhibited a much larger range of values, and maximum values were associated with biological conditions that warranted high concern (table 8). Thresholds for high (if applicable), moderate, and low impairment were assigned by examining the range of values associated with sites that had community condition classifications of high, low, and moderate levels of impairment. Breaks between classes were extrapolated based on index values associated with each impairment class. The resulting thresholds for high $(\mathrm{H})$ levels are $>20$ for metals, $>100$ for agricultural intensity (NAPI index), $>30$ for pesticides in filtered water, $>100$ for pesticides in suspended sediment, $>20$ for pesticides in fish tissues, and $>20$ for overall disturbance. Thresholds for low (L) levels are: $<4$ for metals, $<12$ for agricultural intensity, $<6$ for pesticides in filtered water, $<10$ for pesticides in suspended sediment, $<10$ for pesticides in fish tissues, and $<4$ for overall disturbance. Conditions were assigned to the moderate $(M)$ level if they did not fall in either the high or low category.

The metals index (table 8) indicated that metal enrichment was generally low $(<4)$ throughout the basin with the exception of North Fork Teanaway River, Yakima River at Cle Elum, Wide Hollow Creek, Taneum Creek, and South Fork Manastash Creek. The relatively high levels of chromium, mercury, lead, and nickel at North Fork of the Teanaway River, Yakima River at Cle Elum, Taneum Creek, and South Fork of the Manastash Creek (Appendix A) originate from geologic formations within the upper Yakima River valley (Fuhrer, McKenzie, and others, 1994; Fuhrer, Fluter, and others, 1994; Leland, 1995). Wide Hollow Creek, which drains urban and agricultural areas, showed enrichment in mercury, lead, and zinc that is probably associated with land use rather than with upstream geologic sources because the nearest upstream site (South Fork Ahtanum Creek) did not have elevated metals.

Agricultural intensity, as measured by the NPAI index (table 8), indicated that agriculture is largely confined to the Columbia Basin and varies widely in intensity among these sites. Granger Drain, Moxee Drain, and Spring Creek were affected by high levels of agricultural intensity $(>100)$, while Naches River at North Yakima, Satus Creek below Dry Creek, and Umtanum Creek had low levels of agricultural intensity (similar to levels in the Cascades and Eastern Cascades), which supports their use as reference sites for the Columbia Basin and large-river sites. Total nitrogen was the dominant variable in the NPAI index as indicated by its almost perfect correlation (Spearman rho $>0.99$ ) with this index. With the exception of turbidity and dissolved ammonia, the other elements of the index also were highly correlated with the index and with each other (Spearman rho $>0.81$ ).

The pesticide indices (table 8) also varied widely among the Columbia Basin and large-river sites. Granger Drain, Moxee Drain, Cherry Creek, and Spring Creek had high levels of pesticides. In general, the three pesticide indices were significantly correlated (Spearman rho $\geq 0.87, \mathrm{p}<0.05$ ) with the NPAI index of agricultural intensity indicating the close connection between the use of fertilizers and pesticides in the Yakima River Basin. Even though most pesticides were not measured at Cascades and Eastern Cascades sites nor at Satus Creek below Dry Creek, it is evident from bed-sediment pesticide data, data from sites with similar NPAI index scores (Umtanum Creek, Naches River at North Yakima), and data from Cooper River that pesticide concentrations in the Cascades, Eastern Cascades, and at Satus Creek below Dry Creek are probably near background levels. On this basis, the missing pesticide indices for filtered water and suspended sediment were set to the values reported for Cooper River. Background levels for pesticides in fish tissues were determined by averaging index values for Cascades and Eastern Cascades sites, Satus Creek below Dry Creek, and Umtanum Creek. Estimated background levels were used in 
Table 8. Summary of site conditions determined from indices that characterize metals enrichment, agricultural intensity (NPAI index), pesticide contamination, and disturbance within the Yakima River Basin, Washington

[Thresholds for high (red) levels of metals, agricultural intensity (NPAI index), pesticides in filtered water, pesticides in suspended sediment, pesticides in fish tissues, abd disturbance indices are: $>20,>100,>30,>100,>20$, and $>20$. Thresholds for low (green) levels are $<4,<12,<6,<10,<10$, and $<4$. Conditions were assigned to the moderate (yellow) level if they did not fall in either the high or low category. Missing values precluded the determination of site conditions based on pesticides in bed sediment. HC, Hells Crossing; NF, North Fork; SF, South Fork; Cr, Creek; nr, near; blw, below; YR, Yakima River; N, North; -, index could not be estimated.]

\begin{tabular}{|c|c|c|c|c|c|c|c|c|}
\hline \multirow{3}{*}{$\begin{array}{c}\text { USGS } \\
\text { station } \\
\text { number }\end{array}$} & \multirow[b]{3}{*}{ Site } & \multicolumn{7}{|c|}{ Site condition indices } \\
\hline & & \multicolumn{7}{|c|}{ Index of pesticide concentrations in: } \\
\hline & & $\begin{array}{c}\text { Metals } \\
\text { index }\end{array}$ & $\begin{array}{l}\text { NPAl } \\
\text { index }\end{array}$ & $\begin{array}{c}\text { Filtered } \\
\text { water }\end{array}$ & $\begin{array}{l}\text { Suspended } \\
\text { sediment }\end{array}$ & $\begin{array}{c}\text { Bed } \\
\text { sediment }\end{array}$ & $\begin{array}{c}\text { Fish } \\
\text { tissue }\end{array}$ & $\begin{array}{l}\text { Disturbance } \\
\text { index }\end{array}$ \\
\hline \multicolumn{9}{|c|}{ Cascades site group } \\
\hline $12479750^{\circ}$ & NF Teanaway & 9.6 & 2.6 & $3.0^{\mathrm{a}}$ & $4.0^{a}$ & 4.2 & 0.1 & 1.6 \\
\hline 12481900 & Taneum Creek & 5.4 & 2.8 & $3.0^{\mathrm{a}}$ & $4.0^{a}$ & 4.4 & 0.1 & 1.2 \\
\hline 12483750 & Naneum Creek & 2.3 & 6.4 & $3.0^{\mathrm{a}}$ & $4.0^{a}$ & 4.5 & 0.1 & 1.3 \\
\hline 12488250 & American River at $\mathrm{HC}$ & 3.5 & 4.3 & $3.0^{\mathrm{a}}$ & $410^{a}$ & 1.8 & 0.1 & 12 \\
\hline 12497200 & NF Little Naches River & 2.2 & 3.0 & $3.0^{\mathrm{a}}$ & $4.0 \mathrm{a}$ & - & $0.1 \mathrm{~b}$ & 1.9 \\
\hline \multicolumn{9}{|c|}{ Eastern Cascades site group } \\
\hline 12483190 & SF Manastash Creek & 4.0 & 8.7 & $3.0 \mathrm{a}$ & 4.0 a & 4.6 & 0.1 & 1.6 \\
\hline 12487200 & Little Naches River & 2.5 & 7.1 & $3.0^{\mathrm{a}}$ & $4.0 \mathrm{a}$ & 4.2 & 0.4 & 1.4 \\
\hline 12489100 & Rattlesnake Creek & 2.9 & 4.8 & $3.0 \mathrm{a}$ & 4,0 a & 1.0 & 0.1 & 1.1 \\
\hline 12500900 & SF Ahtanum Creek & 1,4 & 11.4 & $3.0 \mathrm{a}$ & $4.0 \mathrm{a}$ & 5.4 & $0.1^{6}$ & 1.6 \\
\hline 12507594 & Satus Cr nr Toppenish & 2.8 & 9.0 & 1.3 & 3.7 & - & 0.2 & 1.4 \\
\hline \multicolumn{9}{|c|}{ Columbia Basin site group } \\
\hline 12484440 & Cherry Creek & 4.0 & 70.7 & 19.0 & 88.8 & 147.2 & 1.9 & 14.8 \\
\hline 12484550 & Umtanum Creek & 2.2 & 9.4 & 1.6 & 4.9 & 1.2 & 1.3 & 1.6 \\
\hline 12500430 & Moxee Drain & 1.7 & 108.1 & 58.7 & 138.1 & 105.2 & 16.4 & 25.3 \\
\hline 12500442 & Wide Hollow Creek & 4.8 & 79.0 & 11.0 & 20.6 & 26.4 & 13.1 & 10.5 \\
\hline 12502500 & Ahtanum Creek & 2.4 & 60.6 & 6.2 & 15.8 & - & 6.0 & 7.4 \\
\hline 12505460 & Granger Drain & 2.2 & 200.0 & 41.2 & 5046 & 89.7 & 36.5 & 63.3 \\
\hline 12508500 & Satus Cr blw Dry Cr & 1.7 & 6.7 & $3.0^{2}$ & $4.0^{2}$ & 5.0 & 0.4 & 1.4 \\
\hline 12508620 & Satus $\mathrm{Cr}$ at gage & 2.6 & 72.5 & 22.1 & 30.6 & - & 2.4 & 10.6 \\
\hline 12509710 & Spring Creek & 2.2 & 144.4 & 18.2 & 3048 & - & 7.7 & 38.8 \\
\hline \multicolumn{9}{|c|}{ Large-river site group } \\
\hline 12479500 & YR at Cle Elum & 6.2 & 3.4 & 1.4 & 8.0 & - & $\pi .7$ & 1.7 \\
\hline 12484500 & YR at Umtanum & 2.9 & 16.2 & 5.8 & 7.7 & 7.6 & 4.8 & 3.0 \\
\hline 12499000 & Naches $\mathbf{R}$. at N. Yakima & 3.2 & 6.8 & 1..6. & 1.7 & - & 12.7 & 2.1 \\
\hline 12503950 & YR at Parker & 3.2 & 27.5 & $7.2^{\mathrm{C}}$ & $9.8 \mathrm{C}$ & $89.2^{C}$ & 21.9 & 5.7 \\
\hline 12507525 & YR blw Toppenish & 2.9 & 50.5 & $12.5^{d}$ & $50.4^{d}$ & - & 24.9 & 11.5 \\
\hline 12510500 & YR at Kiona & 2.8 & 48.0 & 17.2 & 49.3 & 15.3 & 27.8 & 11.8 \\
\hline
\end{tabular}

${ }^{a}$ Estimated from data collected at Cooper River.

${ }^{b}$ Estimated from concentrations measured at Cascade and Eastern Cascade sites.

c Estimated from data collected at Yakima River above Ahtanum Creek at Union Gap.

d Estimated from data collected at Yakima River at RM 72. 
subsequent multiple regression and community condition indices. Missing values for bed sediment could not be estimated for Ahtanum Creek, Satus Creek at gage, Spring Creek, Naches River at North Yakima, and Yakima River at Toppenish Creek because the data on pesticides in filtered water, suspended sediment, and fish tissues indicated that pesticides in bed sediment at these sites should be well above background levels.

The disturbance index (table 8) indicated that disturbance in the Cascades and Eastern Cascades ecoregion was very low $(<2.0)$. This index emphasizes agricultural effects and is strongly correlated with the NPAI index (Spearman rho $=0.88, \mathrm{p}<0.01$ ) and with the pesticide indices (Spearman rho $=0.61,0.71$, and 0.77 for pesticides in filtered water, suspended sediment, and fish tissues). Silvicultural effects are known to vary among the heavily forested Cascades and Eastern Cascades sites but probably are not well represented by the disturbance index. Therefore, the actual disturbance patterns in the Cascades and Eastern Cascades ecoregions may be substantially different from what is depicted here. In this regard, biological indicators of site condition may be preferable to physical and chemical indicators because biological indicators respond to a broader range of water-quality degradation. Disturbance is substantially higher in the Columbia Basin where index values were $\geq 3$ at all sites except for the three reference sites (Satus Creek below Dry Creek, Umtanum Creek, and Naches River at North Yakima) and Yakima River at Umtanum. Highest levels of disturbance $(>20)$ are associated with Granger Drain, Moxee Drain, and Spring Creek. Progressive increases in disturbance were evident at large-river sites from Yakima River at Umtanum to Yakima River at Kiona.

Overall, these indices are consistent with the ordination results (fig. 5), which indicate that the dominant waterquality issues in the Yakima River Basin relate to intensive irrigated agriculture. Nutrients and pesticides are major factors, along with increases in turbidity and substrate embeddedness, associated with agricultural effects. These effects are greatest at sites receiving significant amounts of irrigation return flows (Cherry Creek, Moxee Drain, Granger Drain, and Spring Creek).

\section{Fish Community Characteristics}

Currently there are no Federally listed endangered or threatened fish species in the Yakima River Basin, Washington (Allan R. Fisher, U.S. Fish and Wildlife Service, written commun., 1996). However, the populations of chinook salmon (Oncorhynchus tshawytscha) that occur in the Snake River, Washington, have been Federally listed as threatened. The U.S. Fish and Wildlife Service also is considering designating the bull trout (Salvelinus confluentus), which is known to occur in Washington, as an endangered or threatened species.

Fishes in the family Salmonidae, including the five Pacific salmon-chum, Oncorhynchus keta; pink, $O$. gorbuscha; coho, $O$. kisutch; chinook, $O$. tshawtscha; and sockeye, $O$. nerka-and rainbow $(O$. mykiss) and cutthroat $(O$. clarki) trout represent important commercial and recreational fisheries for Washington. These fish are widespread throughout the State except for chum and pink salmon, which are restricted in their distribution. Because Pacific salmon are anadromous, they are found in the streams and rivers of the Pacific Northwest as adults during spawning runs and as young returning to the Pacific Ocean. Spawning chinook and coho salmon were encountered at one sampling site (Spring Creek), and sampling had to be terminated to avoid stressing these fish ( $\mathrm{S}$ in table 1). Other fishes that are widely distributed throughout the State are the northern squawfish (Ptychocheilus oregonsis), mountain whitefish (Prosopium williamsoni), largescale sucker (Catostomus macrocheilus), speckled dace (Rhinichthys osculus), redside shiner (Richardsonius balteatus), three-spine stickleback (Gasterosteus aculeatus), and torrent sculpin (Cottus rhotheus) (Wydoski and Whitney, 1979).

Thirty-three fish taxa (5,854 individuals) were collected from 21 sites (table 9). Twenty-two species are considered native species (table 5). Speckled dace was the most abundant species collected, accounting for 27 percent of the total number of fish collected. Rainbow trout and Paiute sculpin accounted for 12 and 10 percent of the total, respectively. Torrent sculpin, redside shiner, largescale sucker, and northern squawfish also were abundant, each accounting for greater than 5 percent of the total number of fish collected. External anomalies were noted on fish taken from Granger Drain, Yakima River at Parker, Yakima River below Toppenish, and Yakima River at Kiona. Six fish collected from Granger Drain (6 percent of the 100 fish examined) had lesions or sores along their bodies. Fifteen fish collected from Yakima River at Parker (13 percent of the 115 fish examined) also had lesions. Fifteen fish collected from Yakima River below Toppenish (11 percent of the 115 fish examined) had lesions or 
Table 9. Common and scientific names of fish, number of individuals, percentage abundance, and number of sites of occurrence for fish collected from 21 sites in the Yakima River Basin, Washington, October and November, 1990

\begin{tabular}{|c|c|c|c|c|}
\hline Common name & Scientific name & Number & $\begin{array}{c}\text { Abundance } \\
\text { (percent) }\end{array}$ & $\begin{array}{c}\text { Number of } \\
\text { sites }\end{array}$ \\
\hline Speckled dace & Rhinichthys osculus & 1,587 & 27 & 9 \\
\hline Rainbow trout & Oncorhynchus mykiss & 694 & 12 & 14 \\
\hline Paiute sculpin & Cottus beldingi & 567 & 10 & 8 \\
\hline Torrent sculpin & Cottus rhotheus & 459 & 8 & 10 \\
\hline Redside shiner & Richardsonius balteatus & 392 & 7 & 7 \\
\hline Largescale sucker & Catostomus macrocheilus & 356 & 6 & 10 \\
\hline Northern squawfish & Ptychocheilus oregonis & 337 & 6 & 12 \\
\hline Mountain whitefish & Prosopium williamsoni & 228 & 4 & 9 \\
\hline Chiselmouth & Acrocheilus alutaceus & 190 & 3 & 6 \\
\hline Bridgelip sucker & Catostomus columbianus & 178 & 3 & 10 \\
\hline Chinook salmon & Oncorhynchus tshawytscha & 156 & 3 & 11 \\
\hline Unidentified sculpins & Cottus spp. & 132 & 2 & 6 \\
\hline Cutthroat trout & Oncorhynchus clarki & 195 & 3 & 8 \\
\hline Longnose dace & Rhinichthys cataractae & 76 & 1 & 7 \\
\hline Shorthead sculpin & Cottus confusus & 64 & 1 & 6 \\
\hline Slimy sculpin & Cottus cognatus & 53 & 1 & 3 \\
\hline Coho salmon & Oncorhynchus kisutch & 48 & 1 & 5 \\
\hline Brook trout & Salvelinus fontinalis & 39 & 1 & 6 \\
\hline Common carp & Cyprinus carpio & 32 & 1 & 4 \\
\hline Mountain sucker & Catostomus platyrhynchus & 38 & 1 & 5 \\
\hline Leopard dace & Rhinichthys falcatus & 9 & $<1$ & 1 \\
\hline Smallmouth bass & Micropterus dolomieu & 1 & $<1$ & 1 \\
\hline Three-spine stickleback & Gasterosteus aculeatus & 5 & $<1$ & 1 \\
\hline Pumpkinseed & Lepomis gibbosus & 4 & $<1$ & 3 \\
\hline Western brook lamprey & Lampetra richardsoni & 3 & $<1$ & 2 \\
\hline Bluegill & Lepomis macrochirus & 2 & $<1$ & 2 \\
\hline Largemouth bass & Micropterus salmoides & 2 & $<1$ & 2 \\
\hline unidentified sunfish & Lepomis spp. & 2 & $<1$ & 1 \\
\hline Dolly Varden & Salvelinus malma & 1 & $<1$ & 1 \\
\hline River lamprey & Lampetra ayresi & 1 & $<1$ & 1 \\
\hline unidentified lamprey & Lampetra sp. & 1 & $<1$ & 1 \\
\hline unidentified minnow & Cyprinidae & 1 & $<1$ & 1 \\
\hline unidentified dace & Rhinichthys sp. & 1 & $<1$ & 1 \\
\hline Total & & 5,854 & & \\
\hline
\end{tabular}


Table 10. Fish taxa richness, abundance, and percentages representing taxonomic groups at each of site 21 sites in the Yakima River Basin, Washington, October and November, 1990

[Percent composition is the percentage of total abundance composed of each taxonomic group. HC, Hells Crossing; SF, South Fork; Cr, Creek; nr, near; blw, below; YR, Yakima River.]

\begin{tabular}{|c|c|c|c|c|c|c|c|c|}
\hline $\begin{array}{c}\text { Station } \\
\text { number }\end{array}$ & Site Name & $\begin{array}{c}\text { Taxa } \\
\text { richness }\end{array}$ & Abundance & $\begin{array}{c}\text { Percent } \\
\text { Salmonidae } \\
\text { (salmon and } \\
\text { trout) }\end{array}$ & $\begin{array}{c}\text { Percent } \\
\text { Cottidae } \\
\text { (sculpins) }\end{array}$ & $\begin{array}{c}\text { Percent } \\
\text { Cyprinidae } \\
\text { (minnows) }\end{array}$ & $\begin{array}{c}\text { Percent } \\
\text { Catostomidae } \\
\text { (suckers) }\end{array}$ & $\begin{array}{c}\text { Percent } \\
\text { Centrachidae } \\
\text { (sunfish) }\end{array}$ \\
\hline \multicolumn{9}{|c|}{ Cascades site group } \\
\hline 12481900 & Taneum Creek & 7 & 356 & 28 & 72 & 0 & 0 & 0 \\
\hline 12483750 & Naneum Creek & 5 & 144 & 23 & 77 & 0 & 0 & 0 \\
\hline 12488250 & American River HC & 9 & 326 & 17 & 83 & 0 & 0 & $\mathbf{0}$ \\
\hline \multicolumn{9}{|c|}{ Eastern Cascades site group } \\
\hline 12483190 & SF Manastash Creek & 6 & 243 & 21 & 79 & 0 & 0 & 0 \\
\hline 12487200 & Little Naches River & 11 & 478 & 37 & 62 & $<1$ & 0 & $\mathbf{0}$ \\
\hline 12489100 & Rattlesnake Creek & 10 & 135 & 33 & 64 & 3 & 0 & 0 \\
\hline 12500900 & SF Ahtanum Creek & 3 & 122 & 51 & 49 & 0 & 0 & $\mathbf{0}$ \\
\hline 12507594 & Satus $\mathrm{Cr}$ nr Toppenish & 4 & 243 & 88 & 1 & 11 & 0 & 0 \\
\hline \multicolumn{9}{|c|}{ Columbia Basin site group } \\
\hline 12484440 & Cherry Creek & 18 & 110 & 22 & 3 & 47 & 19 & 5 \\
\hline 12484550 & Umtanum $\mathrm{Cr}$ & 9 & 195 & 81 & 12 & 6 & 1 & 1 \\
\hline 12500430 & Moxee Drain & 13 & 117 & 17 & 0 & 74 & 9 & 0 \\
\hline 12500442 & Wide Hollow & 7 & 294 & 4 & 0 & 93 & 4 & $\mathbf{0}$ \\
\hline 12502500 & Ahtanum Creek & 16 & 312 & 15 & 17 & 62 & 5 & 1 \\
\hline 12505460 & Granger Drain & 10 & 300 & 4 & 0 & 60 & 36 & 0 \\
\hline 12508500 & Satus Cr blw Dry Cr & 9 & 1,492 & $<1$ & $<1$ & 99 & $<1$ & 0 \\
\hline 12508620 & Satus Creek at gage & 13 & 276 & 0 & 5 & 76 & 18 & 1 \\
\hline \multicolumn{9}{|c|}{ Large-river site group } \\
\hline 12479500 & YR at Cle Elum & 3 & 122 & 100 & 0 & 0 & 0 & 0 \\
\hline 12484500 & YR at Umtanum & 5 & 157 & 43 & 0 & 5 & 52 & 0 \\
\hline 12503950 & YR at Parker & 8 & 222 & 15 & 0 & 18 & 67 & 0 \\
\hline 12507525 & YR at Toppenish & 6 & 145 & 3 & 0 & 35 & 62 & 0 \\
\hline 12510500 & YR at Kiona & 5 & 65 & 32 & 0 & 19 & 49 & 0 \\
\hline
\end{tabular}

eroded fins. Seventeen fish collected at Yakima River at Kiona (28 percent of the 60 fish examined) had lesions, eroded fins, popeye disease, or deformed features.

Taxa richness ranged from 3 at Yakima River at Cle Elum and South Fork Ahtanum Creek to 18 at Cherry Creek (table 10). The number of fish collected at each site ranged from 65 at Yakima River at Kiona to 1,492 at Satus Creek below Dry Creek. At 10 of the sites, members of the families Salmonidae (trout and salmon) and Cottidae (sculpins) together comprised greater than 88 percent of the total number of fish collected at each site. These sites were American River, Naneum Creek, Taneum Creek, Little Naches River near Cliffdell, Rattlesnake Creek, South Fork of Ahtanum Creek, South Fork of Manastash Creek, Satus Creek at Toppenish, Umtanum Creek, and Yakima River at Cle Elum. At seven sites, members of the families Cyprinidae (minnows) and Catostomidae (suckers) together composed greater than 80 percent of the total number of fish collected at each site. These sites were Granger Drain, Moxee Drain, Satus Creek at gage, Satus Creek below Dry Creek, Wide Hollow Creek, Yakima River at Parker, and Yakima River at Toppenish. Members of the family Centrarchidae were present at Ahtanum Creek, Cherry Creek, Satus Creek at gage, and Umtanum Creek. 
Fish community structure can be classified into three broad categories: (1) communities of relatively higher elevation, lower water-temperature tributary sites; (2) communities of lower elevation, warmer water-temperature, tributary sites; and (3) communities of mainstem river sites. In general, cold water streams rarely exceed $25^{\circ} \mathrm{C}$ and typically contain salmonids and sculpins, whereas warm water streams often exceed $25^{\circ} \mathrm{C}$ and are characterized by a more diverse fish fauna, including centrarchids, cyprinids, and catostomids. This pattern was typical of the distribution of fish species observed in the Yakima Basin and was consistent with expected patterns in fish community structure for Pacific Northwest streams (Patten and others, 1970; Li and others, 1987). Data on all fish samples collected are available in digital format (Appendix B).

\section{Benthic Invertebrate Community Characteristics}

A total of 193 invertebrate taxa was identified from quantitative and qualitative samples collected from all 25 sites (table 11; on page 82 of this report). One hundred and eleven taxa were found in the Cascades ecoregion, 101 in the Eastern Cascades ecoregion (130 in both ecoregions), 124 in the Columbia Basin, and 95 in the Columbia Basin large-river sites. Riffles supported the majority of taxa encountered at each site (mean 82 percent, range 62 95 percent) and insects comprised the major portion of invertebrate taxa richness (67 - 98 percent) and abundance (58 - 98 percent). The types and numbers of taxa collected from the Columbia Basin, Cascades, and Eastern Cascades ecoregions were similar to those collected during other studies conducted in this area (table 12) (Plotnikoff, 1995; Carter and others, 1996) despite differences in collection methods and levels of identification. Data on all invertebrate samples collected are included in Appendix C.

Table 12. Comparison of benthic invertebrate community metrics with those reported by the Washington State Department of Ecology

[WSDE site names are those reported in Plotnikoff, 1995. WSDE= Washington State Department of Ecology; USGS= U.S. Geological Survey; EPT = the number of mayfly (Ephemeroptera), stonefly (Plecoptera), and caddisfly (Trichoptera) taxa combined; $\%$, percentage of total abundance; $\mathrm{M}$, Middle.]

\begin{tabular}{|c|c|c|c|c|c|c|}
\hline & \multicolumn{6}{|c|}{ Washington State Department of Ecology site names } \\
\hline & $\begin{array}{c}\text { Little } \\
\text { Naches } \\
\text { River }^{1}\end{array}$ & $\begin{array}{c}\text { American } \\
\text { River }\end{array}$ & $\begin{array}{c}\text { Rattlesnake } \\
\text { Creek }\end{array}$ & $\begin{array}{c}\text { M. Fork } \\
\text { Teanaway } \\
\text { River }^{2} \\
\end{array}$ & $\begin{array}{c}\text { Umtanum } \\
\text { Creek }\end{array}$ & $\begin{array}{l}\text { Upper } \\
\text { Yakima }^{\text {River }} \\
\end{array}$ \\
\hline \multicolumn{7}{|l|}{ Taxa richness } \\
\hline WSDE & 45 & 40 & 37 & 26 & 22 & 21 \\
\hline USGS & 43 & 46 & 52 & 40 & 44 & 33 \\
\hline \multicolumn{7}{|l|}{ EPT taxa richness } \\
\hline WSDE & 32 & 27 & 23 & 17 & 9 & 13 \\
\hline USGS & 30 & 25 & 28 & 20 & 15 & 16 \\
\hline \multicolumn{7}{|c|}{ Dominant taxon (\%) } \\
\hline WSDE & 14 & 11 & 11 & 12 & 39 & 30 \\
\hline USGS & 19 & 20 & 16 & 24 & 28 & 41 \\
\hline \multicolumn{7}{|c|}{ Top two dominant taxa (\%) } \\
\hline WSDE & 27 & 20 & 22 & 22 & 54 & 41 \\
\hline USGS & 35 & 35 & 30 & 36 & 40 & 65 \\
\hline \multicolumn{7}{|c|}{ Stonefly taxa richness } \\
\hline WSDE & 12 & 7 & 7 & 3 & 2 & 1 \\
\hline USGS & 10 & 9 & 9 & 7 & 6 & 6 \\
\hline \multicolumn{7}{|c|}{ Mayfly taxa richness } \\
\hline WSDE & 11 & 9 & 10 & 8 & 4 & 6 \\
\hline USGS & 11 & 9 & 10 & 7 & 5 & 7 \\
\hline
\end{tabular}

${ }^{1}$ Compared with Little Naches River at mouth near Cliffdell.

${ }^{2}$ Compared with North Fork of the Teanaway River.

${ }^{3}$ Compared with Yakima River at Cle Elum. 
Total, EPT (mayfly, stonefly, and caddisfly), and stonefly richnesses were higher (table 13) and community structure was more consistent in the Cascades and Eastern Cascades site groups than in the other site groups. Total richness typically exceeded 50 taxa, and EPT richness usually constituted more than half of the total richness. EPT richness is a particularly important indicator of condition because it has been shown to track other indicators of ecological degradation under experimental conditions (Wallace and others, 1996). Total taxa richness tended to be lower at American River at Hells Crossing, North Fork Teanaway River, Little Naches River near Cliffdell, and Yakima River at Cle Elum than at other sites in the Cascades and Eastern Cascades ecoregions. EPT richness was also lower at North Fork Teanaway River and Yakima River at Cle Elum than at the other sites in this group, perhaps as a result of elevated levels of naturally occurring metals (table 8). Road construction at Yakima River at Cle Elum and American River at Hells Crossing may also have contributed to low richness by decreasing substrate stability. Abundance was much more variable than richness, though there was a tendency for mayfly and stonefly abundances to be higher at sites in the Cascades and Eastern Cascades than at sites in other site groups.

Sites in the Columbia Basin ecoregion (Columbia Basin site group and large-river site group with the exception of Yakima River at Cle Elum) were characterized by fewer total, EPT, and stonefly taxa and more variable community structure than sites in the Cascades and Eastern Cascades ecoregions. Four sites in the Columbia Basin (Granger Drain, Moxee Drain, Spring Creek, and Wide Hollow Creek) were distinguished by very low EPT richness $(<6)$, and no stonefly taxa. Total richness was also very low $(\leq 15)$ for Granger Drain, Moxee Drain and Spring Creek. The low total $(\leq 26)$ and EPT $(<10)$ richnesses at Cherry Creek, Granger Drain, Moxee Drain, Spring Creek, and Wide Hollow Creek are indicative of the effects of intensive agriculture as indicated by the NPAI and pesticide indices (table 8). The three large-river sites located farthest downstream in the basin (Yakima River at Parker, Yakima River below Toppenish, and Yakima River at Kiona) also lacked stoneflies, whereas large-river sites located farther upstream (Yakima River at Umtanum and Naches River near North Yakima) supported stoneflies.

Although many invertebrate taxa were common throughout the basin, a few taxa were restricted to the major site groups (Cascades + Eastern Cascades, Columbia Basin, and large river) and were suitable for differentiating site groups (table 14). Differential taxa were determined using only those sites where agricultural effects were fairly minimal (percentage of basin area in agriculture $\leq 5$ percent, NPAI index $<12$, pesticide indices $<10$ ). A taxon was considered to be differential if it occurred in at least 70 percent of the sites within a group and if the occurrence within the site group was at least five times greater than in any other group. The Cascades and Eastern Cascades site group was characterized by the presence, in riffles, of eight taxa (three species of ephemerellid mayflies, one stonefly, two caddisflies, a midge and a psychodid fly (table 14). In contrast, the Columbia Basin site group was characterized by two mayflies, an odonate, one stonefly, a caddisfly, a moth, one midge, and one fly genus (table 14). Only one taxon, the midge Synorthocladius, was diagnostic of large-river riffles. When all habitats are considered (qualitative and quantitative samples combined), many of the taxa that were diagnostic for the riffle habitat are no longer diagnostic because individuals of these taxa occur in non-riffle habitats. Some non-riffle taxa (gomphid dragonflies, the caddisfly Nectopsyche, the amphipod Hyalella azteca, the crayfish Pacifastacus leniusculus, and the snails Lanx and Physella) were diagnostic of the Columbia Basin site group. The primary effect of including agricultural sites (Columbia Basin sites $>5$ percent agriculture) in the analysis of diagnostic taxa was to substantially reduce the number of taxa that were diagnostic (identified by asterisks in table 14); no taxa were diagnostic from the riffle communities, and only three were diagnostic when all habitats were considered.

Many of these differences were associated with changes in elevation and land use. Elevation affects the distribution of many invertebrate taxa by influencing other physical and biological factors (for example, temperature, riparian conditions, and the quality and quantity of food). The influence of elevation was evident in the distribution of stoneflies, which showed a strong positive relation between elevation and richness (fig. 6). The effect of elevation is manifested in a variety of ways: Umtanum Creek, which has the highest elevation of the Columbia Basin sites, has the highest number of stonefly taxa; stoneflies are not commonly encountered in the mainstem of the Yakima River downstream from Yakima River at Umtanum Creek; and the number of stonefly taxa decreases downstream in the Satus Creek drainage (Satus Creek near Toppenish > Satus Creek below Dry Creek > Satus Creek at gage). Plotnikoff (1995) reported that stonefly taxa richness in Cascade and Columbia Basin streams was influenced by stream size (ratio of wetted channel width to bankfull channel width). While this relation was observed in our data, it was much weaker $\left(r^{2}=0.50\right)$ than the relation with elevation. Carter and others (1996) also observed that species composition varied along an elevation gradient in the Yakima River Basin. 


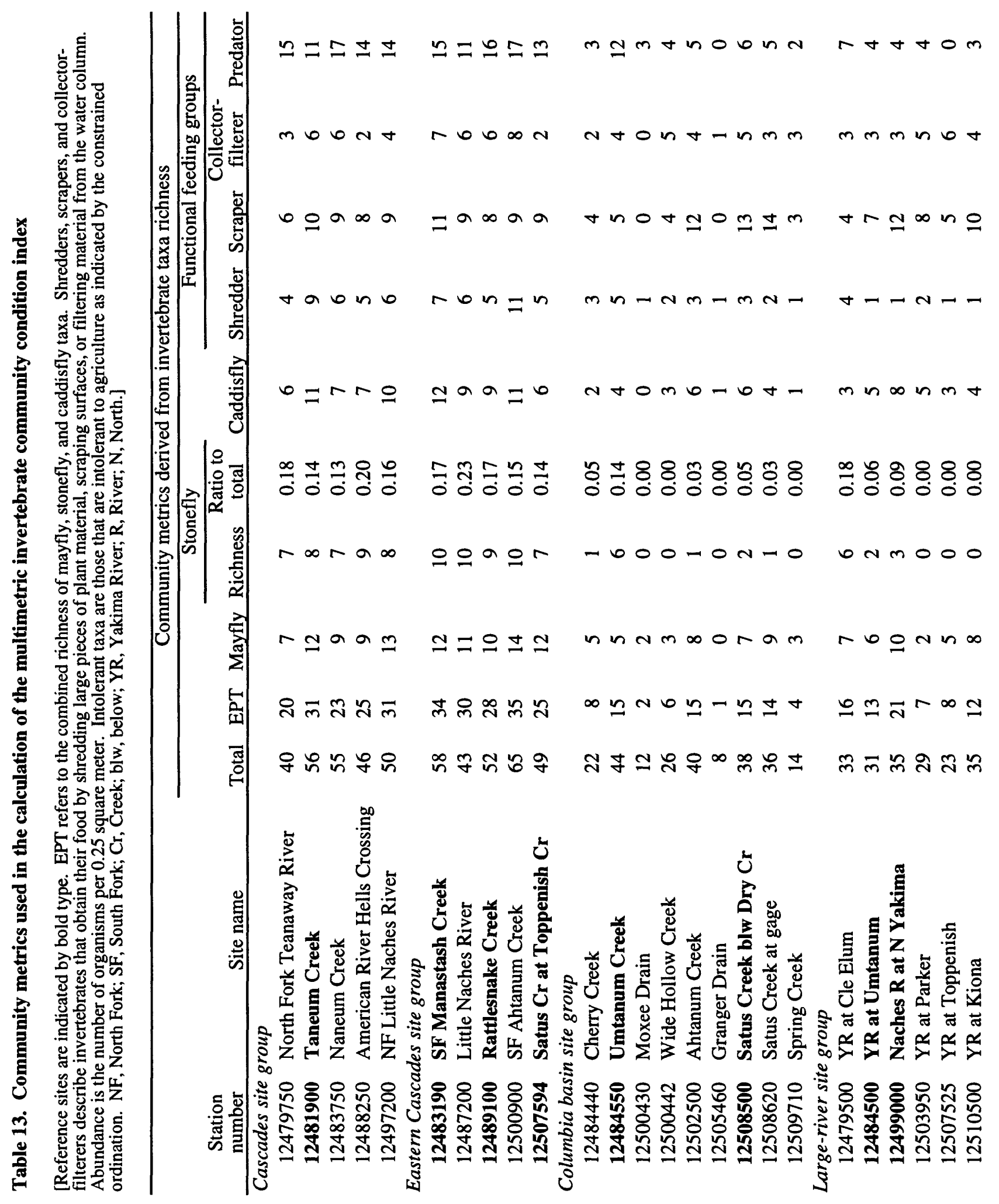




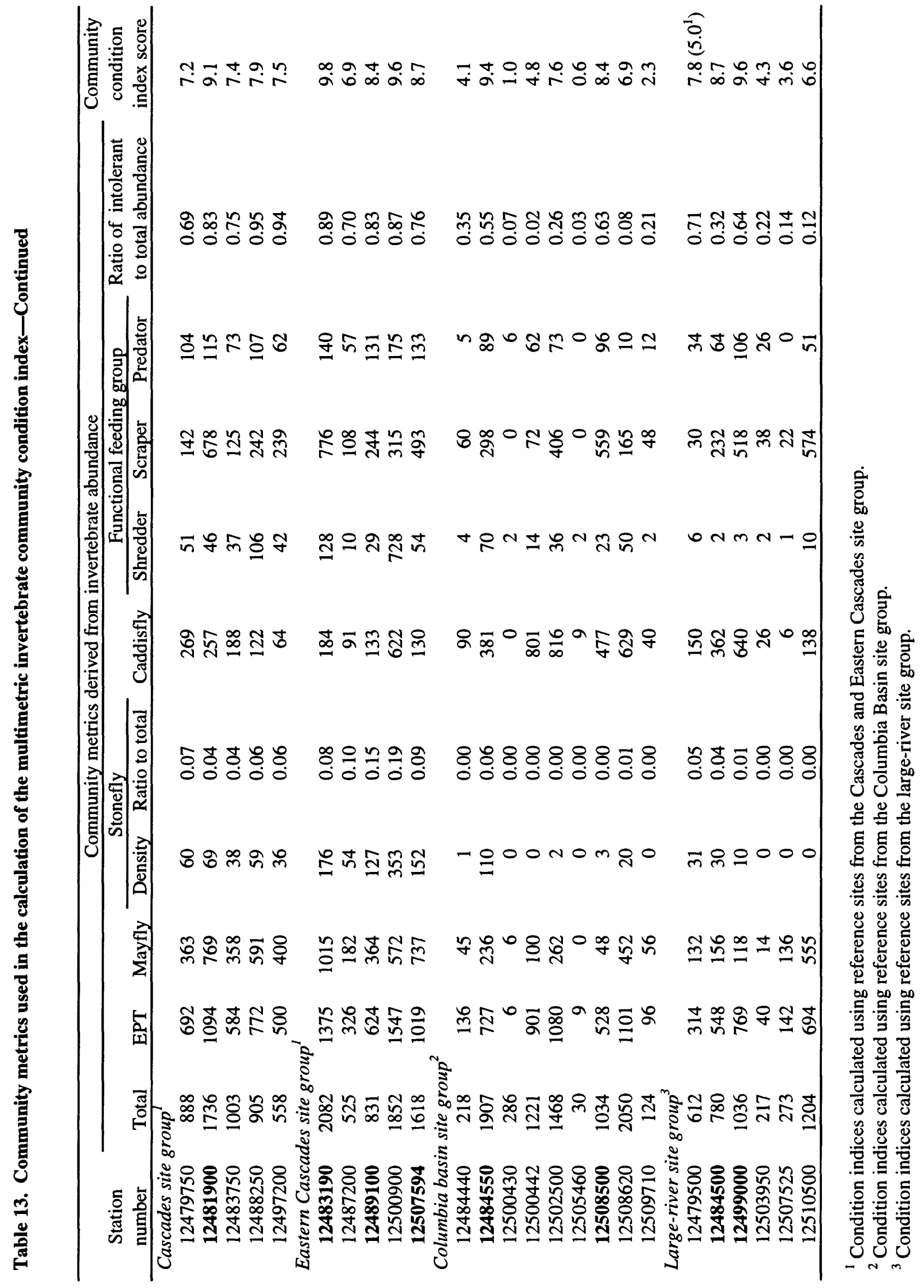


Table 14. Invertebrate taxa that differentiate non-agricultural (less than 5 percent of basin area in agriculture) Columbia Basin sites (Satus Creek below Dry Creek, Umtanum Creek, Ahtanum Creek, and Satus Creek at gage) from sites in the Cascades and Eastern Cascades and large-river site groups.

[A differential taxon is present in at least 70 percent of the sites within a group ( 70 percent fidelity) and fidelity must be five times greater than in any other group. Differential taxa are listed for riffle samples and for multihabitat samples (riffle samples combined with qualitative multihabitat samples). D, differential taxon; ${ }^{*}$, taxon that differentiated site groups when agricultural sites were included;-, taxon did not differentiate sites.]

\begin{tabular}{|c|c|c|c|c|c|c|}
\hline \multirow[b]{2}{*}{ Taxon } & \multicolumn{3}{|c|}{ Riffle samples } & \multicolumn{3}{|c|}{ Multihabitat samples } \\
\hline & $\begin{array}{l}\text { Cascades + } \\
\text { E. Cascades }\end{array}$ & $\begin{array}{c}\text { Columbia } \\
\text { Basin }\end{array}$ & $\begin{array}{l}\text { Large } \\
\text { river }\end{array}$ & $\begin{array}{c}\text { Cascades + E. } \\
\text { Cascades }\end{array}$ & $\begin{array}{c}\text { Columbia } \\
\text { Basin }\end{array}$ & $\begin{array}{l}\text { Large } \\
\text { river }\end{array}$ \\
\hline \multicolumn{7}{|l|}{ Ephemeroptera } \\
\hline Caudatella hystrix & D & - & - & D & - & - \\
\hline Drunella doddsi & D & - & - & D & - & - \\
\hline Drunella grandis & D & - & - & $\mathrm{D}$ & - & - \\
\hline Stenonema sp. & - & $\mathrm{D}$ & - & - & $\mathrm{D}$ & - \\
\hline Tricorythodes sp. & - & D & - & - & D & - \\
\hline \multicolumn{7}{|l|}{ Odonata } \\
\hline Argia sp. & - & D & - & - & D* & - \\
\hline Gomphidae G. sp. & - & - & - & - & D & - \\
\hline \multicolumn{7}{|l|}{ Plecoptera } \\
\hline Sweltsa sp. & D & - & - & - & - & - \\
\hline Taeniopteryx sp. & - & D & - & - & D & - \\
\hline \multicolumn{7}{|l|}{ Trichoptera } \\
\hline Micrasema sp. & D & - & - & D & - & - \\
\hline Cheumatopsyche sp. & - & $\mathrm{D}$ & - & - & $\mathrm{D}$ & - \\
\hline Lepidostoma sp. & D & - & - & - & - & - \\
\hline Nectopsyche $s p$ & - & - & - & - & D & - \\
\hline \multicolumn{7}{|l|}{ Lepidoptera } \\
\hline Petrophila sp. & - & D & - & - & D & - \\
\hline \multicolumn{7}{|l|}{ Diptera } \\
\hline Brillia $s p$ & D & - & - & - & - & - \\
\hline Synorthocladius sp. & - & - & D & - & - & - \\
\hline Thienemanniella sp. & - & $\mathrm{D}$ & - & - & - & - \\
\hline Hemerodromia sp. & - & D & - & - & $\mathrm{D}$ & - \\
\hline Pericoma sp. & D & - & - & D & - & - \\
\hline \multicolumn{7}{|l|}{ Crustacea } \\
\hline Hyalella azteca & - & - & - & - & $\mathrm{D}^{*}$ & - \\
\hline Pacifastacus leniusculus & - & - & - & - & $\mathrm{D}^{*}$ & - \\
\hline \multicolumn{7}{|l|}{ Mollusca } \\
\hline Lanx sp. & - & - & - & - & D & - \\
\hline Physella sp. & - & - & - & - & $\mathrm{D}$ & - \\
\hline Total taxa: & 8 & 8 & 1 & 5 & 13 & 0 \\
\hline
\end{tabular}




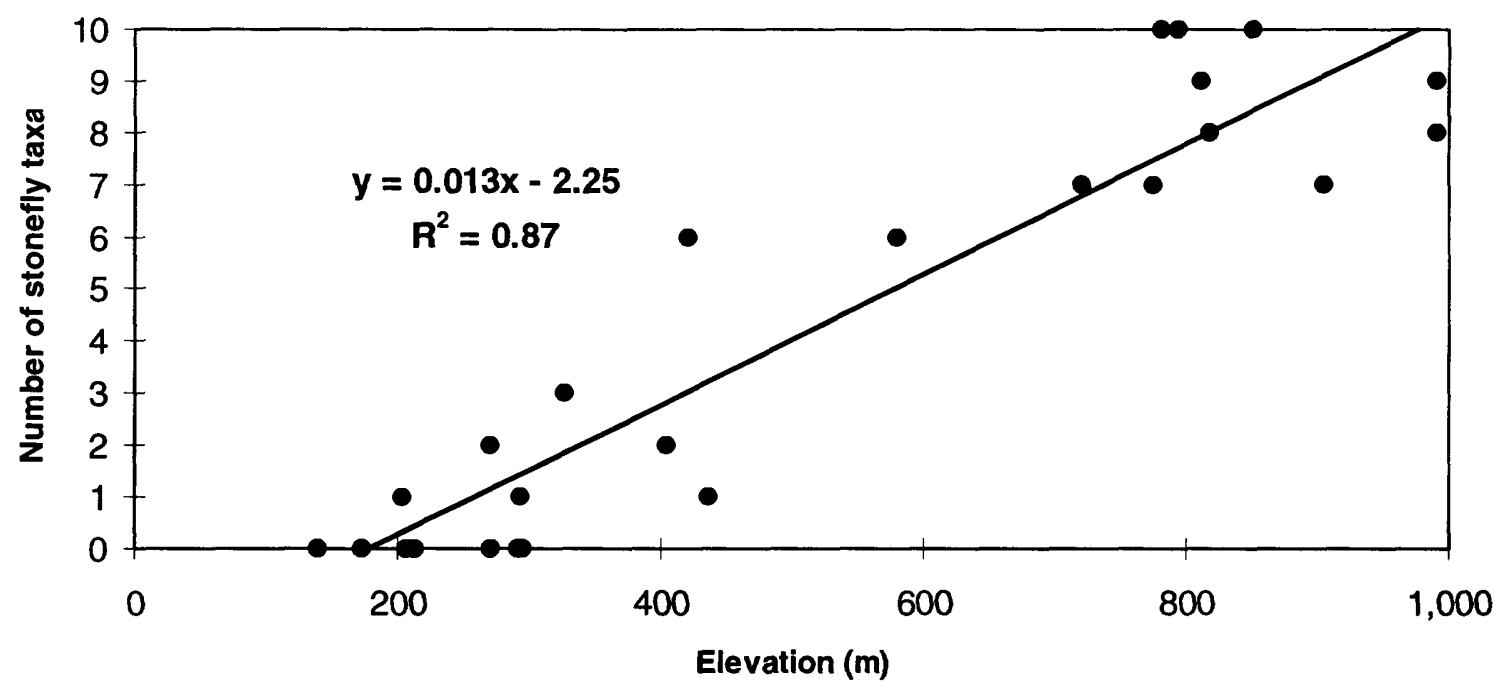

Figure 6. Relation between stonefly taxa richness and elevation in the Yakima River Basin, Washington.

\section{Algal Community Characteristics}

A total of 134 algal taxa was identified during the study (table 15; on page 89 of this report). Taxa richness in quantitative samples from submerged rocks (epilithic microhabitats) ranged from 26 at Rattlesnake Creek to 76 at American River at Hells Crossing (table 16). Diatom taxa constituted 77 to 97 percent of the taxa encountered at all sites; green algae constituted less than 8 percent. Sites in the Cascades and Eastern Cascades site group displayed the largest range in taxa richness (26-76 taxa); sites in the Columbia Basin and large-river site groups displayed a much lower range ( 27 to 40 and 29 to 38, respectively). Algal taxa richness in the Columbia Basin site group did not show the low taxa richnesses that were observed for invertebrates at Granger Drain, Moxee Drain, Spring Creek, Cherry Creek, and Wide Hollow Creek. Algal richness also did not display trends that could be associated with ecoregions, site groups, or agricultural intensity.

Algal abundance varied from about 50,000 cells $/ \mathrm{cm}^{2}$ at Ahtanum Creek and Naneum Creek to over 9,900,000 cells $/ \mathrm{cm}^{2}$ at Satus Creek near Toppenish (table 16). Large variability in abundance was observed in the Cascades, Eastern Cascades, and Columbia Basin site groups. Sites in the Satus Creek drainage had unusually high densities of algae $\left(>3,300,000\right.$ cells $\left./ \mathrm{cm}^{2}\right)$. Algal abundance was greater than $500,000 \mathrm{cells} / \mathrm{cm}^{2}$ at large-river sites. Algal abundances were not related to taxa richness, chlorophyll concentration, or agricultural intensity as measured by the NPAI index.

Algal communities were composed primarily ( $>50$ percent of total abundance) of diatoms (17 sites) or Nostoc (6 sites) at all sites except Satus Creek below Dry Creek and Taneum Creek, which were dominated by Oscillatoria (80 percent) and Microcystis (73 percent), respectively (Appendix D). Microcystis is a blue-green planktonic alga common in eutrophic ponds and lakes (Prescott, 1962) that would not be expected to grow on rocks in streams. However, it was found in abundance at Taneum Creek and in small amounts at American River at Hells Crossing and North Fork Little Naches River. Microcystis could be coming from local sources, such as discharge from beaver ponds or from extensive pooled areas upstream from the Taneum Creek sampling location. When Microcystis is excluded from the community, total algal abundance in Taneum Creek $\left(237,000 \mathrm{cells} / \mathrm{cm}^{2}\right)$ becomes similar to other streams in the region.

The presence of diatoms indicates that concentrations of dissolved silica are sufficient to support productive diatom communities. Green algae were only a minor component ( $<5$ percent of total abundance) at all sites except American River at Hells Crossing, where green algae accounted for 13 percent of total abundance. Filamentous red algae (Audouinella hermanii), aquatic mosses, and nitrogen-fixing algae (Nostoc, Calothrix, Rivularia, and diatoms with blue-green algal endosymbionts) were limited to streams in forested settings of the Cascades and Eastern 


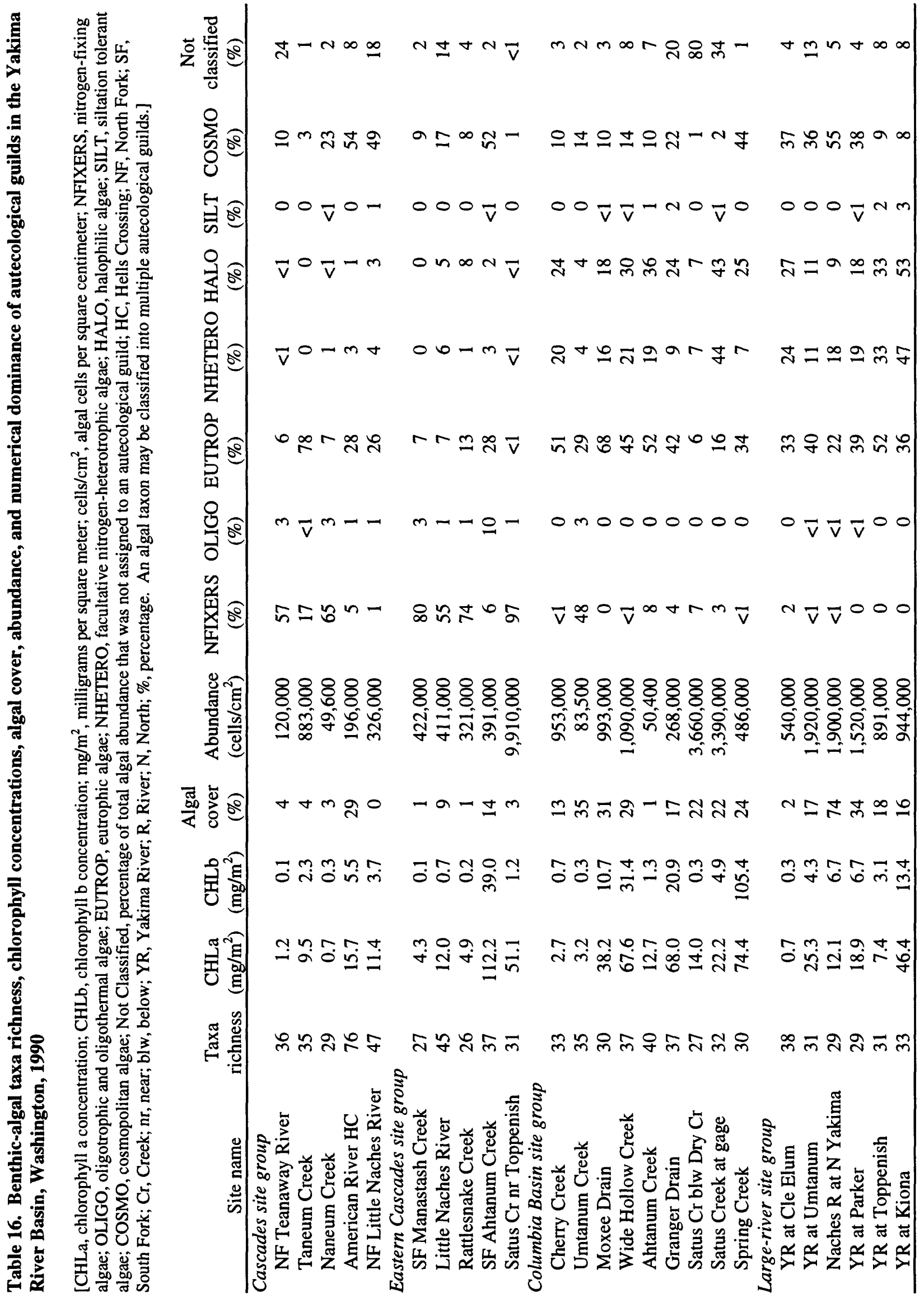


Cascades ecoregions where water temperature is lower, riparian canopy shading is more extensive, and nutrient concentrations are low (Appendix A). Audouinella was not found at Yakima River at Cle Elum, which is a largeriver site located in the Cascades ecoregion. Abundances of Audouinella and other intolerant taxa were low (or absent) in streams potentially affected by soil disturbance from logging (North Fork Little Naches River and South Fork Ahtanum Creek) or road construction (American River at Hells Crossing).

The algal communities of streams in the Cascades and Eastern Cascades site groups tended to be dominated ( $>50$ percent of total abundance) by a single taxon, Nostoc (Satus Creek near Toppenish, 97 percent; South Fork Manastash Creek, 80 percent; Naneum Creek, 64 percent; Rattlesnake Creek, 62 percent; Little Naches River, 55 percent; North Fork Teanaway River, 55 percent of total abundance), whereas communities in streams of the Columbia Basin and large-river site groups were not dominated by a single taxon, with the exception of Satus Creek below Dry Creek (Oscillatoria, 80 percent) and Naches River at North Yakima (Achnanthidium minutissimum, 52 percent).

Algal community composition based on autecological guilds (table 16) revealed that communities were dominated by nitrogen fixers, facultative nitrogen-heterotrophs, eutrophic, halophilic, and cosmopolitan algae. Oligotrophic/oligothermal and siltation tolerant algae were only minor components of algal communities $(<10$ percent of total abundance). Cosmopolitan taxa were the most abundant autecological group at six sites (American River at Hells Crossing, North Fork Little Naches River, South Fork Ahtanum Creek, Spring Creek, Yakima river at Cle Elum, and Naches River at North Yakima). Cosmopolitan algae are widely distributed because, unlike other autecological guilds, they tolerate a wide range of environmental conditions. Therefore, the abundance of cosmopolitan taxa is not indicative of any specific water-quality condition, whereas other autecological groups are indicative of specific water-quality conditions. For example, nitrogen-fixing algae tend to thrive when nitrogen concentrations are low because they can use atmospheric nitrogen, and facultative nitrogen-heterotrophs are indicative of high nitrogen concentrations because they are capable of using reduced nitrogenous compounds as an energy source in addition to photosynthesis (Cholnoky, 1958; 1968; Schoeman, 1973; Lowe, 1974).

Nitrogen-fixing algae were found in abundance at six sites in the Cascades and Eastern Cascades site group (North Fork Teanaway River, Naneum Creek, Little Naches River, Rattlesnake Creek, South Fork Manastash Creek, and Satus Creek near Toppenish), one site in the Columbia Basin site group (Umtanum Creek), and no sites in the large-river site group. Nostoc constituted almost all (84 - 100 percent) of the nitrogen-fixing guild in the Cascades and Eastern Cascades site groups but only 5 percent of the nitrogen-fixing guild in the Columbia Basin site group, which was composed mostly of two species of Epithemia ( $E$. sorex, 36 percent, and $E$. adnata, 5 percent of total abundance). Nitrogen-fixing algae include blue-green algae (cyanobacteria) containing heterocysts (cells adapted for nitrogen fixation (Bold and Wynne, 1978)) and diatoms in the family Epithemiaceae that are known to contain endosymbiont blue-green algae (Geitler, 1977; Fairchild and Lowe, 1984).

Nitrogen heterotrophs and halophils, which were only a minor proportion of abundance $(<10$ percent $)$ in the Cascades and Eastern Cascades site groups, were often a major component ( $>20$ percent) of algal communities in the Columbia Basin and large-river site groups in conjunction with eutrophic algae. The proportion of algal abundance composed of eutrophic algae in streams of the Cascades and Eastern Cascades site groups was inversely related $\left(r^{2}=0.83, p<0.01\right)$ to the relative abundance of Nostoc (nitrogen fixers). Eutrophic, nitrogen heterotrophic, and halophilic algae dominated ( $>20$ percent of total abundance) the communities at most sites in the Columbia Basin and large-river site groups with the exception of Satus Creek below Dry Creek. The autecological status of Satus Creek below Dry Creek could not be established because the autecological status of Oscillatoria, which constituted 80 percent of total abundance at this site, is not known.

Algal taxa were divided into intolerant (nitrogen fixing and oligotrophic/oligothermal algae), tolerant (eutrophic, facultative nitrogen-heterotrophs, halophilic, and siltation tolerant algae), and cosmopolitan groups based on the autecological guilds described in the literature (Lowe, 1974; Fairchild and others, 1985; and Van Dam and others, 1994) (table 16). The abundance of tolerant, intolerant, and cosmopolitan taxa divided the Cascades and Eastern Cascades site groups into three divisions (fig. 7). Six sites (North Fork Teanaway River, Naneum Creek, Little Naches River, Rattlesnake Creek, South Fork Manastash Creek, and Satus Creek near Toppenish) were dominated (56 to 98 percent) by intolerant algae; three sites (North Fork Little Naches River, American River at Hells Crossing, 


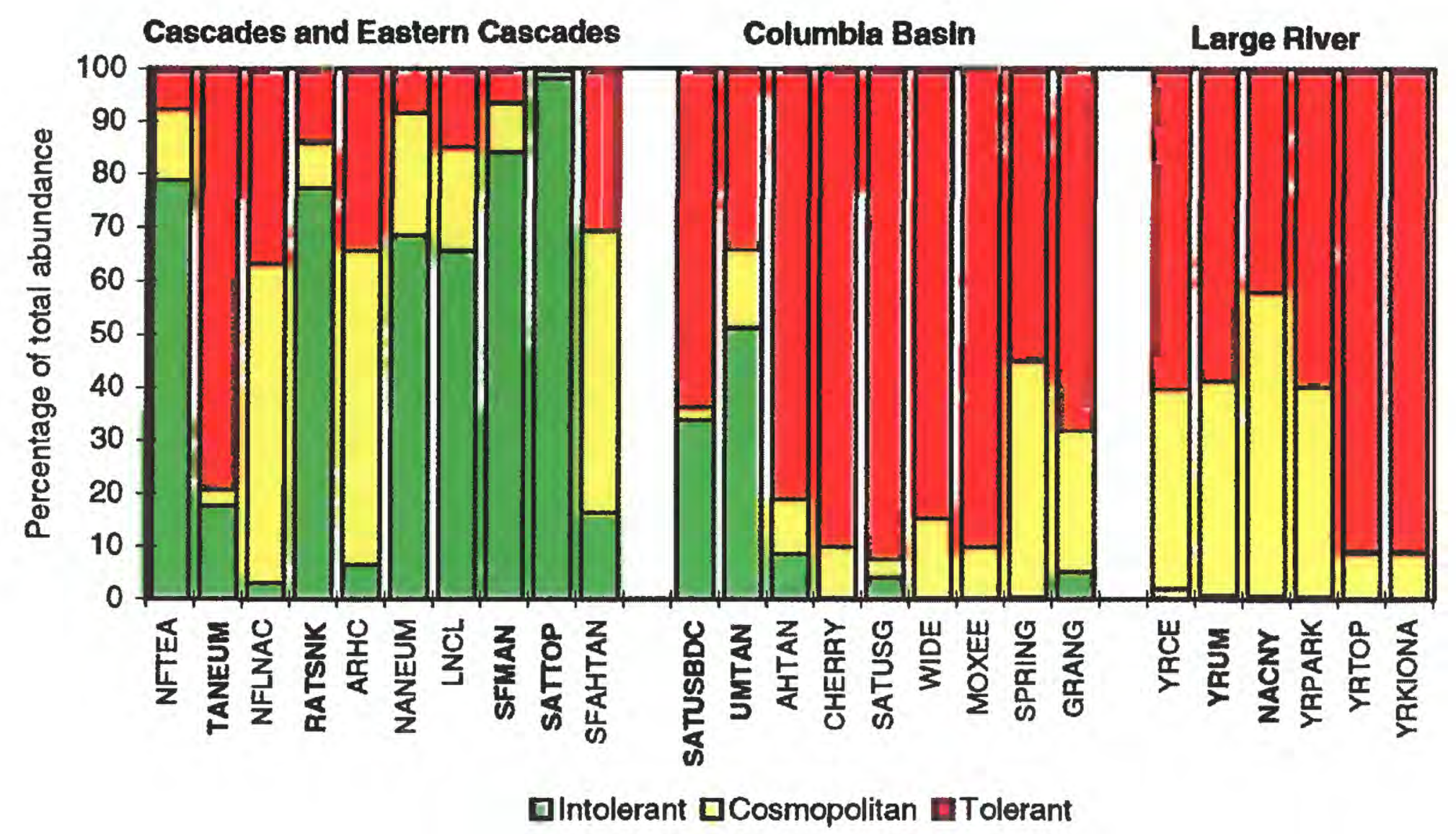

Figure 7. Algal community composition based on autecological classifications described in the literature. (Site abbreviations are given in table 1. Reference sites are shown in bold type.)

and SF Ahtanum Creek) were dominated by a mixture of cosmopolitan (53 to 60 percent) and tolerant ( 31 to 37 percent) taxa, and one site (Taneum Creek) was dominated by tolerant taxa ( 79 percent). The tolerant algae at Taneum Creek were composed almost entirely of Microcystis ( 92 percent).

Umtanum Creek was the only site in the Columbia Basin site group where the algal community was composed primarily of intolerant algae ( 50 percent). All other sites were dominated by tolerant taxa ( 55 to 90 percent) with only a few ( $<10$ percent of total abundance) intolerant taxa. Oscillatoria, the dominant ( 80 percent of total abundance) alga at Satus Creek below Dry Creek, could not be assigned to an autecological guild based on the literature. Consequently, no autecological guild exceeded 10 percent of total abundance at this site. Large-river sites were characterized by a low abundance of intolerant algae ( $<2$ percent) and a high abundance of tolerant algae ( 42 to 91 percent).

The abundance of filamentous green algae, such as Cladophora glomerata, was probably underestimated by the sampling method used in the study. Dense growths of Cladophora were observed in several Columbia Basin streams and agricultural drains (Spring Creek, Wide Hollow Creek, Granger Drain, and Moxee Drain), but algal cell counts do not reflect their visual abundance in these streams. Cladophora and related filamentous-green algae are important indicators of phosphorus and nitrogen enrichment (Whitton, 1970; Lin, 1977; Freeman, 1986). Because the sampling procedures underestimated this group, the influence of agricultural sources of nutrients on algal communities also may have been underestimated. Filamentous green algae are also important because they are typically viewed by the public as an aesthetic nuisance and an indication of water-quality degradation.

Median concentrations of chlorophyll $a$ and $b$ in the Yakima River Basin were 12.7 and $3.1 \mathrm{mg} / \mathrm{m}^{2}$, respectively. The median chlorophyll $a$ concentration in agriculturally affected streams (NPAI Index $>50$ ) of the Columbia Basin site group $\left(38.2 \mathrm{mg} / \mathrm{m}^{2}\right.$ ) was more than three times greater than that of streams in the Cascades and Eastern Cascades 
site group $\left(10.5 \mathrm{mg} / \mathrm{m}^{2}\right)$. Though chlorophyll concentrations were generally low in streams of the Cascades and Eastern Cascades site group, South Fork Ahtanum Creek was an exception. Concentrations of chlorophyll at South Fork Ahtanum Creek were higher than at most of the agriculturally affected streams (table 16) of the Columbia Basin site group. The level of agricultural intensity at South Fork Ahtanum Creek was the highest of the sites in the Cascades and Eastern Cascades site group but was much lower than agriculturally effected streams. Chlorophyll $a$ concentrations varied among agriculturally affected streams of the Columbia Basin site group with relatively high concentrations at some sites (Spring Creek, Granger Drain, Wide Hollow Creek, and Moxee Drain) (table 16) and relatively low concentrations at other sites (Ahtanum Creek and Cherry Creek). Concentrations of chlorophyll $a$ and $b$ concentrations were significantly correlated (Spearman tho $>0.81, \mathrm{p}<0.01$ ) with agricultural intensity (NPAI index) in streams of the Columbia Basin site group, but no significant relations were observed in the other site groups. Chlorophyll $a$ concentrations in streams of the large-river site group were not proportionate with the total abundance of algae or estimates of algal cover (table 16). The ratio of chlorophyll $a$ to chlorophyll $b$ ranged from 0.7 to 46.7 and was greater than 1.0 at all sites except Spring Creek. The ratio of chlorophyll a to chlorophyll $b$ was typically greater than 1.0 because diatoms and blue-green algae (Nostoc), which dominate algal communities in the Yakima River Basin, contain much more chlorophyll $a$ than chlorophyll $b$. The ratio of chlorophyll $a$ to chlorophyll $b$ was low at Spring Creek because the green alga Cladophora, which contains more chlorophyll $b$, was very abundant at this site.

Algal abundance and chlorophyll concentrations varied widely within and among site groups. For example, within the Columbia Basin ecoregion, algal abundance and chlorophyll concentrations were relatively low in Umtanum Creek $\left(83,500\right.$ cells $/ \mathrm{cm}^{2}$ and $3.5 \mathrm{mg} / \mathrm{m}^{2}$ chlorophyll) and Ahtanum Creek $\left(50,400 \mathrm{cells} / \mathrm{cm}^{2}\right.$ and $14 \mathrm{mg} / \mathrm{m}^{2}$ chlorophyll) compared with other streams in this site group $\left(268,00\right.$ to $3,660,000 \mathrm{cells} / \mathrm{cm}^{2}$ and 3.4 to $179.8 \mathrm{mg} / \mathrm{m}^{2}$ chlorophyll). Chlorophyll concentrations in Granger Drain $\left(88.9 \mathrm{mg} / \mathrm{m}^{2}\right)$ and Spring Creek $\left(179.8 \mathrm{mg} / \mathrm{m}^{2}\right)$ were among the largest found in the study (table 16); however, the total abundance of algal cells at these sites was relatively modest $\left(<500,000\right.$ cells $\left./ \mathrm{cm}^{2}\right)$. In contrast, chlorophyll concentrations were disproportionately small relative to total algal abundance in Cherry Creek $\left(3.4 \mathrm{mg} / \mathrm{m}^{2}\right.$ chlorophyll and $\left.953,000 \mathrm{cells} / \mathrm{cm}^{2}\right)$ and at most largeriver sites $\left(<30 \mathrm{mg} / \mathrm{m}^{2}\right.$ chlorophyll and 540,000 to $\left.1,920,000 \mathrm{cells} / \mathrm{m}^{2}\right)$ with the exception of the Yakima River at Kiona $\left(59.8 \mathrm{mg} / \mathrm{m}^{2}\right.$ chlorophyll and $\left.944,000 \mathrm{cells} / \mathrm{m}^{2}\right)$. Sites in the Satus Creek drainage had unusually high algal abundances $\left(>3,000,000 \mathrm{cell} / \mathrm{cm}^{2}\right)$. The abundance of algae in Satus Creek at Toppenish $\left(9,910,000 \mathrm{cells} / \mathrm{cm}^{2}\right)$ was approximately an order of magnitude larger than abundances at other streams in the Cascades and Eastern Cascades site groups, and total algal abundances in Satus Creek below Dry Creek and Satus Creek at gage were the largest observed in the Columbia Basin (table 16). However, chlorophyll concentrations at Satus Creek near Toppenish and Satus Creek at gage were much lower than concentrations measured at sites with much lower algal abundances (Granger Drain, Moxee Drain, Spring Creek, and South Fork Ahtanum Creek). Consequently, chlorophyll concentrations in the Yakima River Basin are not indicative of algal abundances and vice versa.

\section{Community Ordination and Direct Gradient Analysis}

Twenty-seven fish taxa, 73 invertebrate taxa, and 55 algal taxa were used in the constrained ordinations (CCA) along with nine environmental variables (elevation, canopy closure, substrate size, drainage area, and indices of metals enrichment, nonpesticide agricultural intensity, and pesticides in filtered water, suspended sediment, and fish tissue) that represented the major natural and anthropogenic gradients in the basin. The ordination biplots (fig. 8AC) are graphs that depict the main patterns of variation in community composition as accounted for (constrained) by the nine environmental variables. Sites are located in the biplot based on the weighted averages of the species scores associated with each site. These species scores are linear combinations of the environmental variables.

Environmental variables are represented by arrows that approximate the distribution of the species along each environmental variable (ter Braak, 1987). That is, the projection of a species onto an environmental axis (arrow) indicates the relative position of the center of the species' distribution (environmental optimum for the species) along the environmental axis. Environmental variables represented as long arrows are more strongly correlated with the ordination axes than those with short arrows and are more closely related to the pattern of variation in species composition shown in the ordination diagram. The inferred weighted average is higher than average if the projected point of a species lies on the same side of the origin as the head of an arrow and is lower than average if the origin lies between the projected point and the head of the arrow. 
Site groups:

Cascades and E. Cascades

$\triangle$ Columbla Basin

- Large river

Site conditons:

Gunimpaired

¿moderately impaired

$\square$ severely impaired

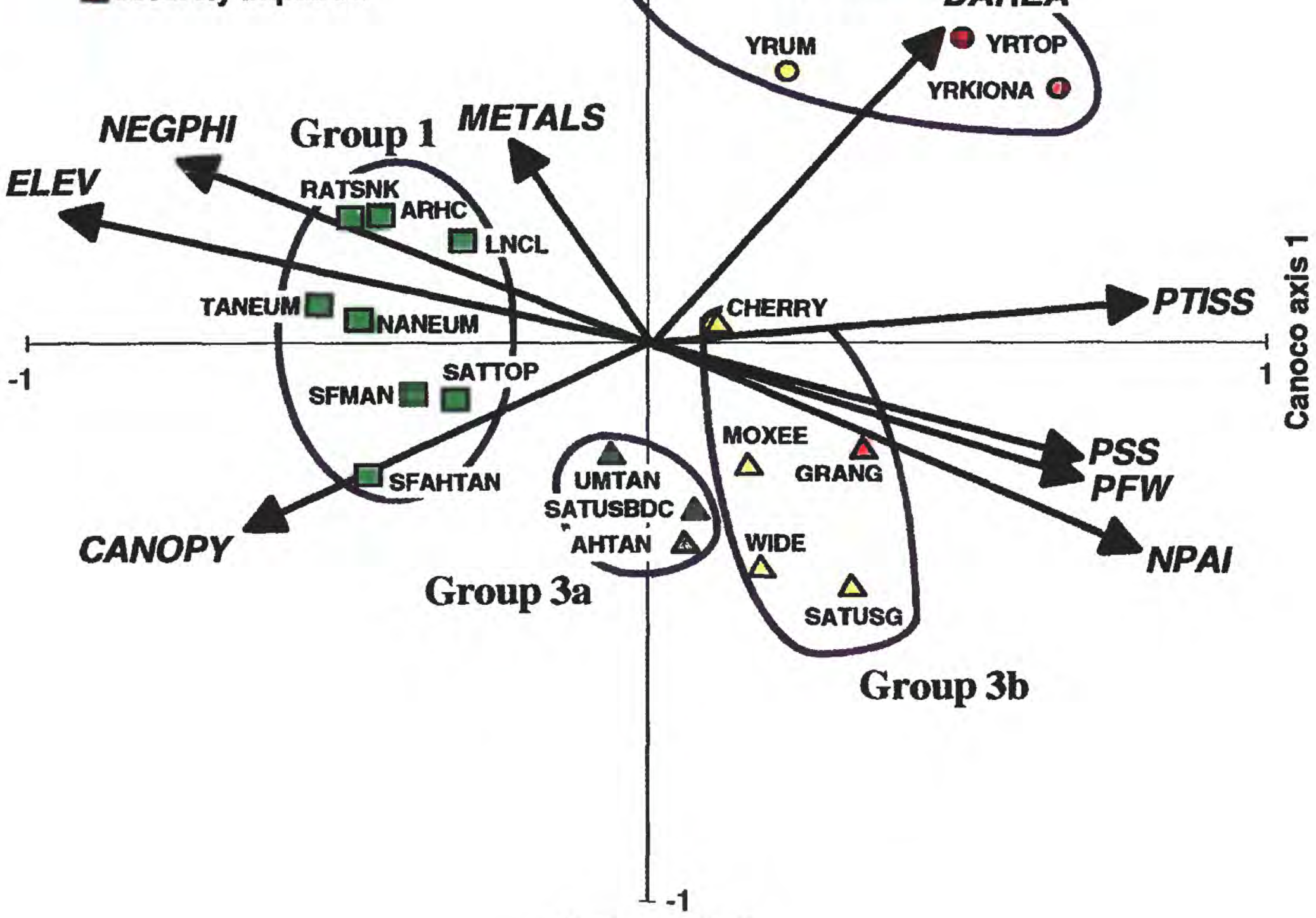

Canoco axis 2

Figure $8 \mathrm{~A}$. Ordination biplot showing the relations among sites in the Yakima River Basin, Washington, based on fish communities. (Abbreviations for sampling sites are listed in table 1; abbreviations for environmental variables are listed in table 3.) 
Site groups:

Cascades and E. Cascades

$\Delta$ Columbia Basin

O Large river

Site conditons:

$\square$ unimpaired

$\square$ moderately impaired

$\square$ severely impaired

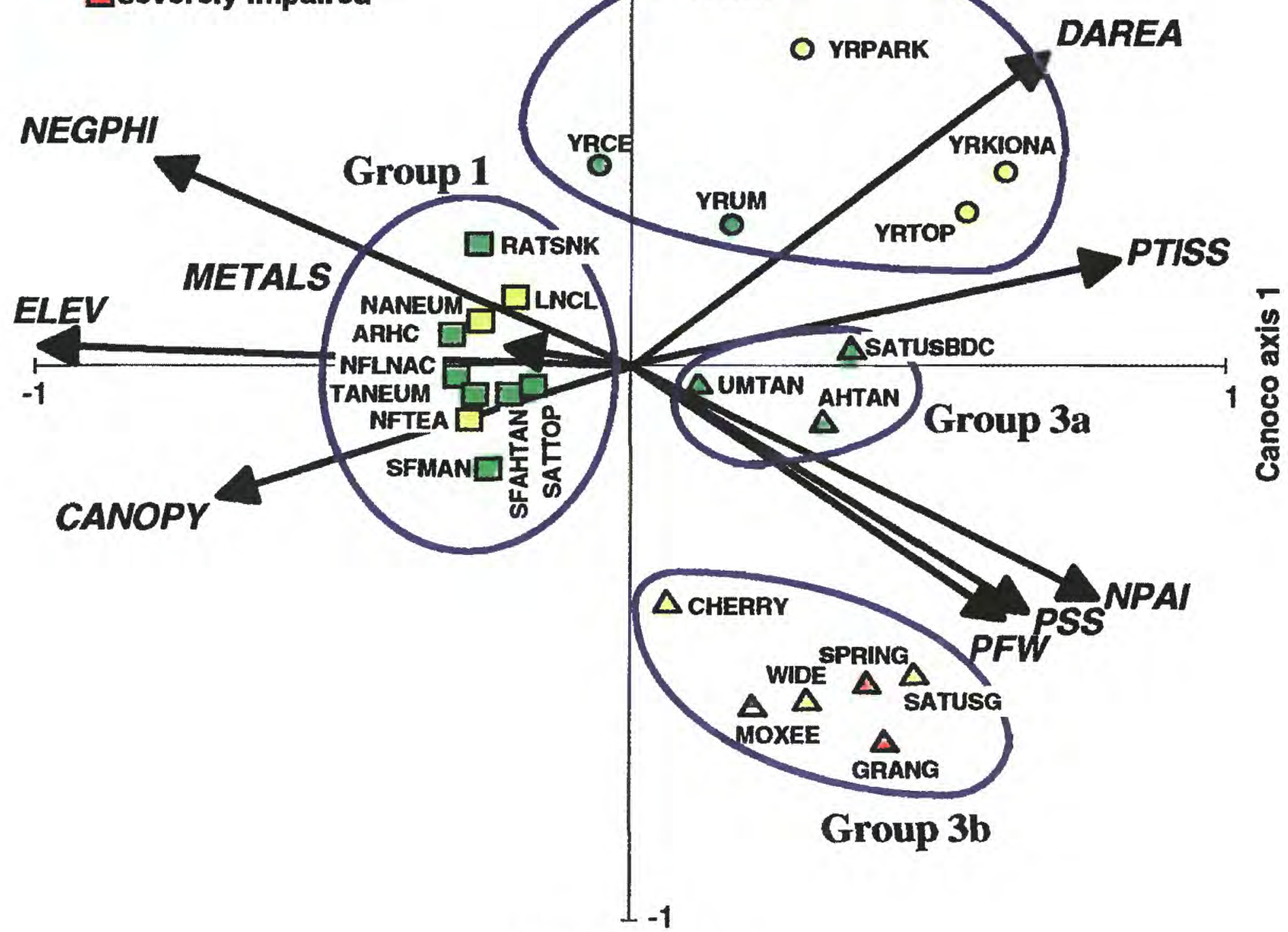

Canoco axis 2

Figure 8 B. Ordination biplot showing the relations among sites in the Yakima River Basin, Washington, based on invertebrate communities. (Abbreviations for sampling sites are listed in table 1; abbreviations for environmental variables are listed in table 3.) 
Site groups:

Cascades and E. Cascades

$\triangle$ Columbia Basin

Large river

Site conditons:

$\square$ unimpaired

$\square$ moderately impaired

severely impaired

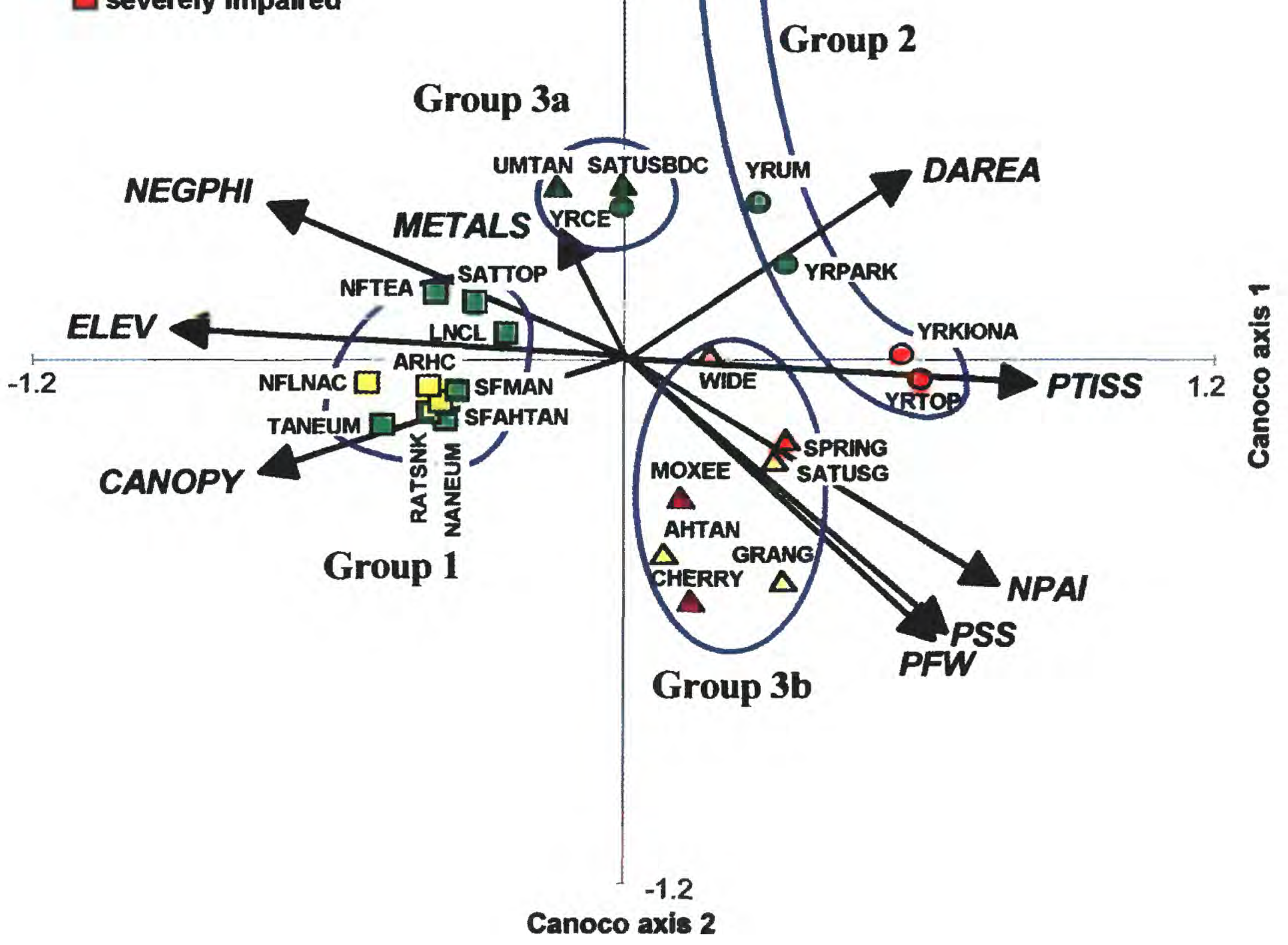

Figure 8 C. Ordination biplot showing the relations among sites in the Yakima River Basin, Washington, based on algal communities. (Abbreviations for sampling sites are listed in table 1; abbreviations for environmental variables are listed in table 3.) 
Species-environment correlations were large $(>0.94)$ for axes 1 and 2 in all of the constrained ordinations. This indicates that the nine environmental variables account for the majority of the variation in species composition. The majority of the variation in species distribution was accounted for by the first ordination axis (fish, 43.2 percent; invertebrates, 46.5 percent; and algae, 48.9 percent). The second ordination axis accounted for considerably less of the variability in the distribution of fish (19.6 percent), invertebrates (11.2 percent), and algae (17.5 percent). The lengths of all environmental variables, except for the index of metals enrichment (METALS), indicated that these variables were strongly correlated with the ordination axes. The relatively short length of the arrow depicting metals enrichment suggests that this was not an important factor in accounting for the distribution of biota among these sites.

The first two ordination axes separated the biological sampling sites into three groups (fig. 8, A-C) that are similar to the site relationships shown by the ordination of physical and chemical site characteristics (fig. 5)-Groupl consists of sites in the Cascades and Eastern Cascades ecoregions; Group 2 consists of large-river sites in the Cascades and Columbia Basin ecoregions; and Group 3 consists of smaller streams of the Columbia Basin ecoregion. Sites in the Cascades and Eastern Cascades group (Group 1) consist of smaller streams (DAREA) with larger substrates (NEGPHI), higher elevations (ELEV), more closed canopies (CANOPY) and little in the way of agricultural effects (PTISS, PSS, PFW, and NPAI). Sites in the large-river site group (Group 2) represent a range of elevation and agricultural effects but tend to be separated from the other site groups by their position along the axis that represents increasing drainage-basin area (DAREA). Group 3 is composed of smaller streams in the Columbia Basin ecoregion and can be subdivided into streams that are affected by agriculture (Group 3b) and those (Umtanum Creek, Satus Creek below Dry Creek, and sometimes Ahtanum Creek) that are relatively unaffected by agriculture (Group 3a). The concentration of metals in bed sediments (METALS index) proved to be the least important (shortest arrow) of the 9 variables chosen to represent the dominant environmental gradients. The other eight environmental variables were of comparable importance (approximately equal length).

The differences in site groupings based on ordinations of fish, invertebrate, and algal communities were relatively minor compared to their common features. The biggest differences were observed in the composition and similarity of subgroups 3a (Columbia Basin, unimpaired sites) and $3 \mathrm{~b}$ (Columbia Basin, agriculturally impaired sites). Umtanum Creek, Satus Creek below Dry Creek, and Ahtanum Creek constituted subgroup 3a for the fish and invertebrate ordinations, but a large-river site (Yakima River at Cle Elum) took the place of Ahtanum Creek in subgroup 3a of the algal ordination. Subgroups $3 a$ and $3 b$ were widely separated (dissimilar) in the ordination of invertebrate and algal communities but not in the ordination of the fish communities. The introduction of non-native game fishes (sunfish and bass) into the Columbia Basin may obscure differences related to agricultural intensity, because these non-native fishes tend to be more tolerant of agriculture than are the native trout, salmon, suckers, and sculpins.

Two sites in the Columbia Basin ecoregion, Umtanum Creek and Satus Creek below Dry Creek (Group 3a), were identified as potential reference sites in the ordination of the physical and chemical site characteristics because they grouped with the Cascades and Eastern Cascades sites (Group 1). In the community ordinations, these sites occur in a group (Group 3a) that was distinct from the Cascades and Eastern Cascades sites (Group 1) and the agriculturally affected Columbia Basin sites (Group 3b). Sites in Group 3a contain communities that are characteristic of the Columbia Basin at low levels of agricultural intensity (low values for NPAI and pesticide indices). Consequently, Umtanum Creek and Satus Creek below Dry Creek represent reference sites for Group 3 that can be used to assess community condition. Ahtanum Creek also grouped with Umtanum and Satus Creek below Dry Creek in the fish and benthic invertebrate community ordinations, suggesting that this may also be a reference site. However, the physical and chemical conditions at this site were more similar to agriculturally affected sites (Wide Hollow Creek and Granger Drain), so this site does not represent reference conditions as well as Umtanum Creek and Satus Creek below Dry Creek.

Three of the four indicators of agriculture (NPAI, PFW, and PSS) were depicted by environmental axes (arrows) that are approximately parallel and in close proximity to one another. This suggests that biota will have similar optima (projection of species scores onto the environmental axis) for fertilizers (NPAI index) and pesticides associated with filtered water and suspended sediment. In contrast, the axis depicting pesticides in fish tissue (PTISS) is not parallel to other indicators of agricultural effects. Consequently, species optima for this indicator of agricultural intensity will be considerably different than for the other indicators of agricultural effects because 
pesticides in fish tissues integrate exposure over time, reflect species-specific differences in pesticide uptake between sites, and integrate spatial differences as fish move within streams of the Yakima River Basin.

Axes associated with indicators of agricultural effects (NPAI, PFW, PSS, and PTISS) tended to run nearly opposite to the axis depicting elevation (arrows nearly opposite in the biplots). Consequently, species optima for agricultural intensity will be nearly opposite those observed for elevation. This simply reflects the fact that agriculture is not possible at higher elevations where the growing season is too short. Consequently, the streams of this study can be broadly divided into two groups: high elevation, nonagricultural streams (Cascades and Eastern Cascades ecoregions) and lower elevation, agricultural streams.

Elevation is the primary factor responsible for separating communities along the first ordination axis as indicated by the high degree of correlation between elevation and ordination axis 1 ( -0.93 fish, -0.97 invertebrates, and -0.89 algae). Elevation is also significantly correlated with 43 (table 17) of the 54 physical and chemical variables used to characterize sites and construct indices (table 2). The overriding influence of elevation makes it difficult to separate effects related to land use (percentage of basin area in forest, agriculture, and rangeland; percentage of flow originating from forest, irrigated agriculture, or urban areas) or associated with land use (for example, turbidity, conductivity, total nitrogen, dissolved ammonia, dissolved nitrite and nitrate nitrogen, and total phosphorus) from effects related to elevation. This is particularly problematic because elevation can profoundly affect the distribution of organisms and vegetation patterns even in the absence of human effects by influencing climatic variables such as temperature and precipitation.

The effects of elevation can be minimized by examining relations within site groups that encompass a relatively narrow range of elevations. The Columbia Basin (Group 3) and Cascades and Eastern Cascades (Group 1) site groups each encompass a relatively narrow range of elevations that makes it possible to investigate the response of biota to water quality within each site group with reasonable assurances that the results are not grossly confounded by the influence of elevation. In contrast, the large-river site group (Group 2) cannot be separated from the large changes in elevation associated with the longitudinal profile of the Yakima River. Therefore, caution must be exercised in interpreting the response of large-river communities to water-quality conditions. Unfortunately, the small number of sites in each of the site groups (6 to 10) precludes using multivariate analyses as a means of further exploring community responses to water-quality variables within each site group. Consequently, multivariate methods of examining community responses to environmental variables are limited to a consideration of the entire basin, whereas investigations of water-quality relations within each site group are based on multimetric procedures. The multimetric procedures reduce the effects of elevation by using reference conditions that are specific to each site group (elevation group).

\section{Environmental Preferences of Fish, Invertebrates and Algae}

The environmental preferences of fish, invertebrates, and algae were inferred by projecting the species scores onto the axes representing the nine environmental variables used in the CCA (Jongman and others, 1987). These projections correspond to the approximate ranking of the weighted averages of the species with respect to the environmental variable; that is, they indicate the approximate location of the optima for the species relative to the environmental variable. The environmental preferences (optima) for biota show some common features when preferences are ordered by elevation-the environmental variable that accounts for the majority of the variation in species distributions. Environmental optima were arranged along a gradient from high-elevation sites with large substrates, closed canopies, and little agricultural influence to low-elevation sites with smaller substrates, open canopies, and large agricultural influence.

The fish were divided into three community types (table 18 ) broadly associated with elevation, water temperature, and agricultural intensity. The community associated with high-elevation, cold-water streams with low levels of agriculture is composed primarily of salmonids and sculpins. The community type associated with lower elevation, warm-water streams with moderate to high levels of agriculture is composed primarily of minnows, sunfish, bass, carp, and suckers. The third community type is intermediate to the first two and is composed of some cold-water (Prosopium williamsoni) and warm-water (Lepomis) species. Native species make up the majority of the 
Table 17. Spearman rank correlations (rho) between elevation and other environmental variables used to characterize sites in the Yakima River Basin, Washington, 1990

[Only significant $(\mathrm{p} \leq 0.05)$ correlations are shown; *, a significant $(0.01<\mathrm{p} \leq 0.05)$ correlation; **, a highly significant $(\mathrm{p} \leq 0.01)$ correlation]

Positive correlations

\begin{tabular}{lrcc}
\hline $\begin{array}{c}\text { Environmental } \\
\text { variables (table 2) }\end{array}$ & rho & Probability & $\begin{array}{c}\text { Number of } \\
\text { samples }\end{array}$ \\
\hline SOCP & 0.77 & $* *$ & 25 \\
TOC & 0.77 & $* *$ & 25 \\
FORF & 0.75 & $* *$ & 25 \\
FORA & 0.73 & $* *$ & 20 \\
NEGPHI & 0.68 & $* *$ & 25 \\
CANOPY & 0.65 & $* *$ & 25 \\
COV & 0.64 & $* *$ & 24 \\
LI & 0.60 & $* *$ & 25 \\
ALP & 0.58 & $* *$ & 25 \\
ZN & 0.54 & $* *$ & 25 \\
SLOPE & 0.51 & $* *$ & 25
\end{tabular}

Negative correlations

\begin{tabular}{|c|c|c|c|}
\hline $\begin{array}{c}\text { Environmental } \\
\text { variables (table 2) }\end{array}$ & rho & Probability & $\begin{array}{c}\text { Number of } \\
\text { samples }\end{array}$ \\
\hline TEMP & -0.86 & $* *$ & 24 \\
\hline COND & -0.78 & ** & 25 \\
\hline IRRF & -0.76 & ** & 25 \\
\hline TN & -0.72 & ** & 25 \\
\hline $\mathrm{DOC}$ & -0.72 & $* *$ & 22 \\
\hline DNO23 & -0.70 & $* *$ & 25 \\
\hline SO4 & -0.70 & * & 12 \\
\hline AGA & -0.66 & ** & 20 \\
\hline $\mathrm{KP}$ & -0.65 & $* *$ & 25 \\
\hline TP & -0.64 & $* *$ & 25 \\
\hline DCA & -0.64 & $*$ & 12 \\
\hline DOP & -0.63 & $* *$ & 25 \\
\hline MGP & -0.60 & $* *$ & 25 \\
\hline ALK & -0.58 & $*$ & 12 \\
\hline $\mathrm{PH}$ & -0.57 & $* *$ & 25 \\
\hline TNH4O & -0.52 & ** & 25 \\
\hline ALGAE & -0.51 & ** & 25 \\
\hline CAP & -0.51 & ** & 25 \\
\hline SN & -0.51 & ** & 25 \\
\hline TURB & -0.49 & $*$ & 25 \\
\hline RANGA & -0.49 & * & 20 \\
\hline DNH4 & -0.48 & * & 25 \\
\hline UNUSF & -0.48 & * & 23 \\
\hline BA & -0.46 & * & 25 \\
\hline URBA & -0.46 & * & 20 \\
\hline NAP & -0.45 & * & 25 \\
\hline URBF & -0.45 & * & 25 \\
\hline EMBED & -0.44 & * & 25 \\
\hline CHLA & -0.44 & $*$ & 25 \\
\hline PB & -0.44 & * & 25 \\
\hline CHLB & -0.43 & * & 25 \\
\hline SOCMGL & -0.43 & * & 22 \\
\hline
\end{tabular}




\section{Table 18. Environmental optima for fish from canonical correspondence analysis}

[Optima were determined by projecting the species scores in the canonical correspondence analysis onto the axis representing the environmental variable or index. The projected scores have been multiplied by 10 and rounded to the nearest whole number. Large positive values indicate that the species optima are associated with high levels of the environmental variable or index; large negative values indicate that optima are associated with low levels.]

\begin{tabular}{|c|c|c|c|c|c|c|c|c|c|}
\hline \multirow[b]{2}{*}{ Taxon } & \multirow[b]{2}{*}{ Elevation } & \multirow[b]{2}{*}{$\begin{array}{l}\text { Substrate } \\
\text { size }\end{array}$} & \multirow[b]{2}{*}{$\begin{array}{l}\text { Canopy } \\
\text { closure }\end{array}$} & \multirow[b]{2}{*}{$\begin{array}{c}\text { Drainage } \\
\text { area }\end{array}$} & \multirow[b]{2}{*}{$\begin{array}{c}\text { Metals } \\
\text { index }\end{array}$} & \multirow[b]{2}{*}{$\begin{array}{l}\text { NPAI } \\
\text { index }\end{array}$} & \multicolumn{3}{|c|}{ Pesticide index } \\
\hline & & & & & & & $\begin{array}{l}\text { Filtered } \\
\text { water }\end{array}$ & $\begin{array}{c}\text { Suspended } \\
\text { sediment }\end{array}$ & $\begin{array}{l}\text { Fish } \\
\text { tissue }\end{array}$ \\
\hline \multicolumn{10}{|c|}{ High elevation, cold-water streams with little agricultural influence } \\
\hline Salvelinus malma & 15 & 16 & 10 & -4 & 13 & -16 & -16 & -16 & -14 \\
\hline Cottus cognatus & 13 & 13 & 9 & -4 & 10 & -13 & -13 & -13 & -12 \\
\hline Salvelinus fontinalis & 12 & 11 & 10 & -7 & 7 & -11 & -11 & -11 & -12 \\
\hline Oncorhynchus clarki & 12 & 11 & 12 & -9 & 6 & -11 & -11 & -12 & -13 \\
\hline Cottus confusus & 11 & 11 & 8 & -5 & 8 & -11 & -11 & -11 & -10 \\
\hline Oncorhynchus kisutch & 10 & 10 & 6 & -3 & 9 & -10 & -10 & -10 & -9 \\
\hline Cottus beldingi & 10 & 10 & 9 & -7 & 6 & -10 & -10 & -10 & -11 \\
\hline Cottus rhotheus & 9 & 9 & 8 & -6 & 5 & -8 & -9 & -9 & -9 \\
\hline Oncorhynchus mykiss & 6 & 6 & 5 & -3 & 4 & -6 & -6 & -6 & -6 \\
\hline Cottus spp. & 6 & 6 & 6 & -5 & 3 & -6 & -6 & -6 & -7 \\
\hline \multicolumn{10}{|c|}{ Lower elevation, warm-water streams with little agricultural influence } \\
\hline Oncorhynchus tshawytscha & 1 & 1 & -1 & 2 & 2 & -2 & -1 & -1 & 0 \\
\hline Rhinichthys cataractae & -1 & -2 & 2 & -3 & -4 & 2 & 2 & 1 & 0 \\
\hline Gasterosteus aculeatus & -3 & -3 & -3 & 3 & -1 & 3 & 3 & 3 & 3 \\
\hline Lepomis spp. & -3 & -3 & -3 & 3 & -1 & 3 & 3 & 3 & 3 \\
\hline Prosopium williamsoni & -4 & -1 & -12 & 14 & 7 & 1 & 2 & 3 & 8 \\
\hline \multicolumn{10}{|c|}{ Lower elevation, warm water streams with moderate to high levels of agriculture } \\
\hline Lepomis gibbosus & -4 & -5 & 0 & -3 & -7 & 5 & 5 & 5 & 2 \\
\hline Lampetra richardsoni & -4 & -5 & 1 & -3 & -7 & 5 & 5 & 4 & 2 \\
\hline Micropterus salmoides & -4 & -4 & 0 & -2 & -6 & 5 & 4 & 4 & 2 \\
\hline Micropterus dolomieu & -5 & -6 & 3 & -7 & -10 & 7 & 6 & 5 & 1 \\
\hline Lampetra sp. & -5 & -6 & 3 & -7 & -10 & 7 & 6 & 5 & 1 \\
\hline Cyprinidae & -5 & -6 & 3 & -7 & -10 & 7 & 6 & 5 & 1 \\
\hline Rhinichthys sp. & -5 & -6 & 3 & -7 & -10 & 7 & 6 & 5 & 1 \\
\hline Rhinichthys osculus & -6 & -7 & 0 & -3 & -9 & 7 & 7 & 6 & 4 \\
\hline Richardsonius balteatus & -7 & -9 & -1 & -4 & -11 & 9 & 8 & 8 & 4 \\
\hline Ptychocheilus oregonis & -8 & -7 & -6 & 3 & -5 & 7 & 7 & 8 & 7 \\
\hline Catostomus columbianus & -8 & -6 & -10 & 9 & -1 & 6 & 7 & 7 & 9 \\
\hline Lepomis macrochirus & -8 & -9 & -3 & 0 & -9 & 9 & 8 & 8 & 6 \\
\hline Catostomus macrocheilus & -9 & -7 & -11 & 10 & -1 & 7 & 8 & 8 & 10 \\
\hline Catostomus platyrhynchus & -9 & -10 & -4 & 0 & -10 & 10 & 10 & 9 & 7 \\
\hline Acrocheilus alutaceus & -9 & -9 & -5 & 2 & -8 & 9 & 9 & 9 & 7 \\
\hline Rhinichthys falcatus & -11 & -12 & -7 & 2 & -10 & 12 & 12 & 11 & 10 \\
\hline Cyprinus carpio & -11 & -8 & -20 & 20 & 4 & 8 & 9 & 11 & 16 \\
\hline Lampetra ayresi & -13 & -14 & -3 & -3 & -16 & 15 & 14 & 13 & 9 \\
\hline
\end{tabular}


cold-water community, whereas the warm-water community contained a variety of introduced species (for example, sunfish, bass, and carp). Carp (Cyprinus carpio), suckers (Catostomus), leopard dace (Rhinichthys falcatus), and the river lamprey (Lampetra ayresi) were the fishes most tolerant of agriculture. Salmonids (Salvelinus malma, $S$. fontinalis, Oncorhynchus clarki, O. kisutch, and $O$. mykiss) and sculpins (Cottus cognatus, C. confusus, C. beldingi, and $C$. rhotheus) were the least tolerant of agriculture.

Invertebrates also were divided into three broad community types (table 19) based on elevation and agricultural influences. Thirty-six taxa composed the community associated with high-elevation, cold-water streams, with low agricultural intensity. This community is composed primarily of mayflies ( 7 taxa), stoneflies (10 taxa), and caddisflies ( 7 taxa). In contrast, the community associated with lower elevations, warmer waters, and higher levels of agriculture was composed of 23 taxa, of which midges were the most common taxa (6). Stoneflies were entirely absent from this community, and mayflies ( 3 taxa) and caddisflies ( 4 taxa) were a relatively minor component of the community. Molluscs (Ferrissia and Physella), crustaceans (Hyalella azteca and Pacifastacus leniusculus), odonates (Argia), and lepidoptera (Petrophila) also characterize the lower elevation, warm-water, higher agriculture community. Functional differences were also evident between these two community types. The community associated with higher elevations and low levels of agriculture had more species of predators (15) and shredders (6) than did the community associated with lower elevations and higher levels of agriculture ( 3 taxa in each group). The number of scraper taxa was twice as high (8) in the lower elevation, higher agriculture community. Several taxa associated with the low-elevation, higher agriculture community (Hydroptila, Leucotrichia, Petrophila, Stenonema, Rheotanytarsus, Lumbriculidae, and Ferrissia) also showed a preference for larger rivers (larger drainage basin area). Unlike fish, a fairly large number of invertebrates (19 taxa) did not show strong environmental preferences. These taxa are located near the mean value ( 0 ) for each environmental variable and constituted a third community associated with lower elevations, warm-water streams with relatively low levels of agriculture.

The differences in invertebrate community structure (taxonomic and functional) indicate that the community associated with higher elevations and lower levels of agriculture represents a rich assemblage of sensitive insects (mayflies, stoneflies, and caddisflies) characteristic of small, cold, mountain streams with low levels of nutrients (relatively low scraper richness) and containing a community of insects that utilizes coarse particulate organic matter (relatively high shredder richness) originating from relatively intact riparian zones (relatively high canopy closure). In contrast, the community associated with lower elevation sites with higher levels of agriculture have fewer sensitive insects, more non-insects, and more scrapers indicating that algal production may be stimulated by nutrients from agricultural sources and increased light levels associated with open canopies.

The tolerances of benthic invertebrates for agriculture were determined by converting the preferences observed for the NPAI and pesticide indices to a scale of 0 (least tolerant) to 10 (most tolerant) and then calculating an average of the values for each of the four indices. Each index was scaled by setting the distance from the minimum to the maximum value equal to 10 units with the restriction that a preference of zero correspond to a value of five units. Average values were rounded to the nearest whole number. These agricultural tolerance scores were compared to tolerance scores derived from Hilsenhoff (1987) and Bode (1988). Fifty-one of the agricultural tolerances were similar; that is, the scores were within two units of each other (table 20) for the 73 taxa considered in the CCA. The Hilsenhoff-Bode tolerances were more than 2 units higher for 17 taxa and more than 2 units lower for 5 taxa. The high degree of similarity between the agricultural tolerances derived from CCA and the Hilsenhoff-Bode tolerance values is unexpected since the Hilsenhoff-Bode tolerances were developed primarily to detect point sources of organic pollution using family-level identifications of Wisconsin and New York fauna. The primary water-quality problems in the Yakima River Basin are elevated levels of nutrients, pesticides, and turbidity associated with agricultural runoff. Therefore, the effects on biota are probably considerably different from organic pollution (that is, more toxicity and autotrophy rather than low dissolved-oxygen concentration and increased concentrations of dissolved organic carbon and fine particulate organic matter). The agricultural tolerances also show a high variability within families (for example, optima for non-Chironomini midges varied from 1 to 9 , heptageniid mayflies varied from 1 to 10 , and hydropsychid caddisflies varied from 0 to 6 ), which indicates that family-level identifications and tolerances may not be sufficient for understanding the responses of invertebrates to agriculture. 


\section{Table 19. Environmental optima for invertebrates derived from the canonical correspondence}

analysis

[Optima were determined by projecting the species scores in the canonical correspondence analysis onto the axis representing the environmental variable or index. The projected scores have been multiplied by 10 and rounded to the nearest whole number. Large positive values indicate that the species optima are associated with high levels of the environmental variable or index; large negative values indicate that optima are associated with low levels.]

\begin{tabular}{|c|c|c|c|c|c|c|c|c|c|}
\hline \multirow[b]{2}{*}{ Taxon } & \multirow[b]{2}{*}{ Elevation } & \multirow[b]{2}{*}{$\begin{array}{c}\text { Substrate } \\
\text { size }\end{array}$} & \multirow[b]{2}{*}{$\begin{array}{l}\text { Canopy } \\
\text { closure }\end{array}$} & \multirow[b]{2}{*}{$\begin{array}{c}\text { Drainage } \\
\text { area }\end{array}$} & \multirow[b]{2}{*}{$\begin{array}{l}\text { Metals } \\
\text { index }\end{array}$} & \multirow[b]{2}{*}{$\begin{array}{l}\text { NPAI } \\
\text { index }\end{array}$} & \multicolumn{3}{|c|}{ Pesticide indices } \\
\hline & & & & & & & $\begin{array}{c}\text { Filtered } \\
\text { water }\end{array}$ & $\begin{array}{c}\text { Suspended } \\
\text { sediment }\end{array}$ & $\begin{array}{l}\text { Fish } \\
\text { tissue }\end{array}$ \\
\hline \multicolumn{10}{|c|}{ High elevation, cold-water streams with little agricultural influence } \\
\hline Megarcys & 9 & 9 & 8 & -6 & 9 & -8 & -8 & -8 & -8 \\
\hline Hexatoma & 9 & 8 & 8 & -6 & 9 & -8 & -7 & -8 & -8 \\
\hline Caudatella & 8 & 7 & 7 & -6 & 8 & -7 & -7 & -7 & -8 \\
\hline Drunella doddsi & 8 & 7 & 8 & -7 & 8 & -7 & -7 & -7 & -8 \\
\hline Eucapnopsis brevicauda & 8 & 7 & 8 & -7 & 8 & -7 & -6 & -6 & -8 \\
\hline Sweltsa & 8 & 7 & 7 & -5 & 8 & -7 & -7 & -7 & -7 \\
\hline Hesperoperla pacifica & 8 & 6 & 8 & -7 & 7 & -6 & -5 & -6 & -8 \\
\hline Perlinodes & 8 & 8 & 7 & -5 & 9 & -8 & -8 & -8 & -8 \\
\hline Micrasema & 8 & 7 & 7 & -6 & 8 & -7 & -7 & -7 & -8 \\
\hline Arctopsyche grandis & 8 & 8 & 7 & -6 & 8 & -7 & -7 & -7 & -8 \\
\hline Lepidostoma & 8 & 7 & 8 & -7 & 8 & -7 & -6 & -6 & -8 \\
\hline Brillia & 8 & 7 & 7 & -6 & 8 & -7 & -7 & -7 & -7 \\
\hline Pericoma & 8 & 7 & 8 & -7 & 8 & -7 & -6 & -6 & -8 \\
\hline Glutops & 8 & 7 & 8 & -7 & 8 & -6 & -6 & -6 & -8 \\
\hline Dicranota & 8 & 8 & 7 & -5 & 8 & -8 & -8 & -8 & -7 \\
\hline Cinygmula & 7 & 6 & 7 & -6 & 7 & -6 & -5 & -6 & -7 \\
\hline Rhyacophila brunnea & 7 & 6 & 7 & -7 & 7 & -6 & -5 & -6 & -8 \\
\hline Bezzia & 7 & 6 & 8 & -8 & 7 & -5 & -5 & -5 & -8 \\
\hline Aulodrilus americanus & 6 & 4 & 8 & -8 & 6 & -4 & -3 & -3 & -7 \\
\hline Drunella grandis & 6 & 7 & 5 & -3 & 7 & -7 & -7 & -7 & -6 \\
\hline Ephemerella & 6 & 5 & 6 & -6 & 6 & -5 & -5 & -5 & -6 \\
\hline Zapada & 6 & 6 & 5 & -4 & 6 & -5 & -5 & -5 & -6 \\
\hline Isoperla & 6 & 6 & 5 & -4 & 6 & -6 & -6 & -6 & -6 \\
\hline Rhyacophila vaccua & 6 & 6 & 6 & -5 & 6 & -6 & -5 & -5 & -6 \\
\hline Epeorus & 5 & 6 & 4 & -2 & 5 & -6 & -6 & -6 & -4 \\
\hline Calineuria californica & 5 & 5 & 5 & -4 & 5 & -5 & -5 & -5 & -5 \\
\hline Apatania & 5 & 6 & 3 & -1 & 5 & -6 & -6 & -6 & -4 \\
\hline Rhithrogena & 4 & 5 & 3 & -1 & 5 & -5 & -5 & -5 & -3 \\
\hline Skwala & 4 & 5 & 3 & -1 & 4 & -5 & -5 & -5 & -3 \\
\hline Brachycentrus & 4 & 6 & 3 & -1 & 5 & -6 & -6 & -6 & -3 \\
\hline Chelifera & 4 & 4 & 4 & -3 & 4 & -4 & -4 & -4 & -4 \\
\hline Telmatodrilus vejdovskyi & 3 & 2 & 3 & -3 & 2 & -2 & -2 & -2 & -3 \\
\hline Pteronarcys & 3 & 4 & 2 & -1 & 4 & -4 & -4 & -4 & -2 \\
\hline Tanytarsus & 3 & 1 & 4 & -5 & 2 & -1 & 0 & 0 & -4 \\
\hline Thienemannimyia & 3 & 1 & 4 & -5 & 2 & -1 & 0 & 0 & -4 \\
\hline Antocha & 3 & 3 & 3 & -2 & 3 & -3 & -3 & -3 & -3 \\
\hline
\end{tabular}


Table 19. Environmental optima for invertebrates derived from canonical correspondence analysis-Continued

\begin{tabular}{|c|c|c|c|c|c|c|c|c|c|}
\hline \multirow[b]{2}{*}{ Taxon } & \multirow[b]{2}{*}{ Elevation } & \multirow[b]{2}{*}{$\begin{array}{c}\text { Substrate } \\
\text { size }\end{array}$} & \multirow[b]{2}{*}{$\begin{array}{l}\text { Canopy } \\
\text { closure }\end{array}$} & \multirow[b]{2}{*}{$\begin{array}{c}\text { Drainage } \\
\text { area }\end{array}$} & \multirow[b]{2}{*}{$\begin{array}{c}\text { Metals } \\
\text { index }\end{array}$} & \multirow[b]{2}{*}{$\begin{array}{l}\text { NPAI } \\
\text { index }\end{array}$} & \multicolumn{3}{|c|}{ Pesticide indices } \\
\hline & & & & & & & $\begin{array}{l}\text { Filtered } \\
\text { water }\end{array}$ & $\begin{array}{l}\text { Suspended } \\
\text { sediment }\end{array}$ & $\begin{array}{l}\text { Fish } \\
\text { tissue }\end{array}$ \\
\hline \multicolumn{10}{|c|}{ Lower elevation, warm-water streams with little agricultural influence } \\
\hline Attenella & 2 & 2 & 1 & 0 & 2 & -2 & -2 & -2 & -1 \\
\hline Heterlimnius & 2 & 2 & 3 & -3 & 2 & -1 & -1 & -1 & -3 \\
\hline Narpus & 2 & 2 & 2 & -1 & 2 & -2 & -2 & -2 & -2 \\
\hline Baetis bicaudatus & 1 & 1 & 1 & -1 & 1 & -1 & -1 & -1 & -1 \\
\hline Paraleptophlebia & 1 & 0 & 1 & -2 & 1 & 0 & 0 & 0 & -1 \\
\hline Acentrella insignificans & 0 & 2 & -2 & 4 & 1 & -3 & -3 & -3 & 1 \\
\hline Optioservus & 0 & 0 & 0 & -1 & 0 & 0 & 1 & 1 & 0 \\
\hline Hydracarina & -1 & -2 & 0 & -1 & -1 & 2 & 2 & 2 & 1 \\
\hline Turbellaria & -2 & -3 & -1 & 0 & -2 & 3 & 3 & 3 & 2 \\
\hline Zaitzevia & -2 & -1 & -2 & 2 & -1 & 1 & 0 & 0 & 2 \\
\hline Ceratopsyche & -3 & -3 & -2 & 1 & -3 & 3 & 3 & 3 & 3 \\
\hline Microtendipes & -3 & 0 & -5 & 6 & -2 & -1 & -1 & -1 & 4 \\
\hline Paratanytarsus & -3 & -3 & -2 & 1 & -3 & 4 & 4 & 4 & 2 \\
\hline Eukiefferiella & -3 & -1 & -4 & 5 & -2 & 1 & 0 & 0 & 4 \\
\hline \multicolumn{10}{|c|}{ Lower elevation, warm-water streams with moderate to high levels of agriculture } \\
\hline Hydroptila & -4 & 0 & -8 & 10 & -3 & -1 & -2 & -2 & 7 \\
\hline Cricotopus & -4 & -4 & -3 & 2 & -4 & 4 & 4 & 4 & 4 \\
\hline Orthocladius & -4 & -5 & -4 & 2 & -5 & 5 & 4 & 5 & 4 \\
\hline Pacifastacus leniusculus & -5 & -5 & -4 & 3 & -5 & 5 & 5 & 5 & 5 \\
\hline Baetis tricaudatus & -5 & -5 & -4 & 3 & -5 & 5 & 4 & 4 & 4 \\
\hline Rheotanytarsus & -5 & -2 & -8 & 9 & -5 & 2 & 1 & 1 & 7 \\
\hline Rhyacodrilus coccineus & -6 & -5 & -5 & 4 & -6 & 5 & 5 & 5 & 6 \\
\hline Glossosoma & -6 & -5 & -6 & 5 & -6 & 5 & 5 & 5 & 6 \\
\hline Cardiocladius & -6 & -3 & -7 & 7 & -5 & 3 & 2 & 2 & 7 \\
\hline Simulium & -6 & -6 & -4 & 2 & -6 & 6 & 6 & 6 & 5 \\
\hline Cheumatopsyche & -7 & -6 & -7 & 6 & -7 & 6 & 5 & 5 & 7 \\
\hline Lumbriculidae & -8 & -4 & -10 & 11 & -7 & 4 & 2 & 3 & 9 \\
\hline Polypedilum & -8 & -12 & -3 & -2 & -10 & 13 & 14 & 13 & 5 \\
\hline Ferrissia & -10 & -8 & -11 & 10 & -10 & 8 & 7 & 7 & 11 \\
\hline Argia & -11 & -11 & -10 & 8 & -11 & 11 & 10 & 10 & 10 \\
\hline Thienemanniella & -11 & -14 & -7 & 2 & -12 & 14 & 15 & 15 & 8 \\
\hline Hemerodromia & -11 & -11 & -9 & 6 & -11 & 11 & 11 & 11 & 10 \\
\hline Physella & -12 & -12 & -11 & 9 & -12 & 12 & 11 & 11 & 12 \\
\hline Hyalella azteca & -12 & -13 & -9 & 5 & -12 & 13 & 13 & 13 & 10 \\
\hline Tricorythodes & -12 & -12 & -10 & 7 & -12 & 12 & 12 & 12 & 11 \\
\hline Leucotrichia & -12 & -6 & -16 & 17 & -11 & 6 & 3 & 4 & 15 \\
\hline Petrophila & -12 & -8 & -13 & 12 & -11 & 8 & 7 & 7 & 13 \\
\hline Stenonema & -19 & -15 & -19 & 17 & -18 & 15 & 13 & 14 & 19 \\
\hline
\end{tabular}


Table 20. Comparison of invertebrate tolerances derived from canonical correspondence analysis with tolerances determined by Hilsenhoff (1987), Bode (1988), and Wisseman (Mark Munn, U.S. Geological Survey, written commun., 1996)

[Agricultural tolerance is derived by projecting the species scores onto the axes representing the NPAI and pesticide indices in the canonical correspondence analysis. Projected scores are averaged and scaled to give a range of 0 to 10. The agricultural tolerance score increases as agricultural intensity increases. Agricultural tolerance classes were derived from agricultural tolerance scores: $0-3$ intolerant (I), 4-6 moderately tolerant (M), 7-10 tolerant (T). Bold type indicates that the agricultural tolerance score and the Hilsenhoff-Bode tolerance score differed by more than 2 units.]

\begin{tabular}{|c|c|c|c|c|c|}
\hline \multirow[b]{2}{*}{ Taxon } & \multirow[b]{2}{*}{$\begin{array}{c}\text { Agricultural } \\
\text { tolerance }\end{array}$} & \multirow[b]{2}{*}{$\begin{array}{c}\text { Agricultural } \\
\text { tolerance } \\
\text { score }\end{array}$} & \multirow[b]{2}{*}{$\begin{array}{c}\text { Agricultural } \\
\text { tolerance } \\
\text { class }\end{array}$} & \multicolumn{2}{|c|}{ Literature tolerances } \\
\hline & & & & $\begin{array}{l}\text { Hilsenhoff-Bode } \\
\text { tolerance score }\end{array}$ & $\begin{array}{c}\text { Wisseman } \\
\text { tolerance } \\
\text { class }\end{array}$ \\
\hline Turbellaria & 0.27 & 5 & $M$ & 4 & - \\
\hline Lumbriculidae & 0.36 & 5 & M & 6 & - \\
\hline Aulodrilus americanus & -0.39 & 2 & I & 8 & $\mathbf{T}$ \\
\hline Rhyacodrilus coccineus & 0.52 & 6 & $M$ & 8 & $\mathrm{~T}$ \\
\hline Telmatodrilus vejdovskyi & -0.19 & 3 & 1 & 8 & $\mathbf{T}$ \\
\hline Ferrissia & 0.79 & 7 & $\mathrm{~T}$ & 6 & $\mathrm{~T}$ \\
\hline Physella & 1.16 & 9 & $\mathrm{~T}$ & 7 & $\mathrm{~T}$ \\
\hline Hydracarina & 0.19 & 4 & $M$ & 4 & - \\
\hline Hyalella azteca & 1.30 & 9 & $\mathbf{T}$ & 4 & $\mathbf{T}$ \\
\hline Pacifastacus leniusculus & 0.48 & 6 & $M$ & 6 & - \\
\hline Acentrella insignificans & -0.28 & 2 & I & 4 & - \\
\hline Baetis bicaudatus & -0.15 & 3 & 1 & 4 & 1 \\
\hline Baetis tricaudatus & 0.45 & 6 & $M$ & 4 & - \\
\hline Attenella & -0.20 & 3 & 1 & 1 & 1 \\
\hline Caudatella & -0.72 & 1 & 1 & 1 & 1 \\
\hline Drunella doddsi & -0.72 & 1 & 1 & 1 & 1 \\
\hline Drunella grandis & -0.68 & 1 & 1 & 1 & 1 \\
\hline Ephemerella & -0.52 & 1 & 1 & 1 & - \\
\hline Cinygmula & -0.60 & 1 & $\mathbf{I}$ & 4 & - \\
\hline Epeorus & -0.56 & 1 & $\mathbf{I}$ & 4 & $\mathbf{I}$ \\
\hline Rhithrogena & -0.51 & 1 & I & 4 & - \\
\hline Stenonema & 1.49 & 10 & $\mathbf{T}$ & 4 & $\mathbf{T}$ \\
\hline Paraleptophlebia & 0.01 & 4 & $M$ & 2 & - \\
\hline Tricorythodes & 1.21 & 9 & $\mathbf{T}$ & 4 & I \\
\hline Argia & 1.08 & 8 & $\mathrm{~T}$ & 9 & $\mathrm{~T}$ \\
\hline Eucapnopsis brevicauda & -0.68 & 1 & 1 & 1 & - \\
\hline Sweltsa & -0.74 & 0 & 1 & 1 & - \\
\hline Zapada & -0.54 & 1 & 1 & 2 & 1 \\
\hline Calineuria californica & -0.50 & 1 & 1 & 1 & - \\
\hline Hesperoperla pacifica & -0.61 & 1 & 1 & 1 & - \\
\hline Isoperla & -0.62 & 1 & 1 & 2 & - \\
\hline Megarcys & -0.85 & 0 & 1 & 2 & - \\
\hline Perlinodes & -0.83 & 0 & 1 & 2 & - \\
\hline Skwala & -0.46 & 2 & 1 & 2 & - \\
\hline Pteronarcys & -0.42 & 2 & 1 & 0 & 1 \\
\hline Brachycentrus & -0.58 & 1 & I & 1 & - \\
\hline
\end{tabular}


Table 20. Comparison of invertebrate tolerances derived from canonical correspondence analysis with tolerances determined by Hilsenhoff (1987), Bode (1988), and Wisseman (Mark Munn, U.S. Geological Survey, written commun., 1996)—Continued

[The agricultural tolerance score increases as agricultural intensity increases. Agricultural tolerance classes were derived from agricultural tolerance scores: $0-3$ intolerant (I), 4-6 moderately tolerant (M), 7-10 tolerant (T).]

\begin{tabular}{|c|c|c|c|c|c|}
\hline \multirow[b]{2}{*}{ Taxon } & \multirow[b]{2}{*}{$\begin{array}{c}\text { Agricultural } \\
\text { tolerance }\end{array}$} & \multirow[b]{2}{*}{$\begin{array}{c}\text { Agricultural } \\
\text { tolerance } \\
\text { score }\end{array}$} & \multirow[b]{2}{*}{$\begin{array}{l}\text { Agricultural } \\
\text { tolerance } \\
\text { class }\end{array}$} & \multicolumn{2}{|c|}{ Literature tolerances } \\
\hline & & & & $\begin{array}{l}\text { Hilsenhoff-Bode } \\
\text { tolerance score }\end{array}$ & $\begin{array}{c}\text { Wisseman } \\
\text { tolerance } \\
\text { class }\end{array}$ \\
\hline Micrasema & -0.73 & 1 & 1 & 1 & - \\
\hline Glossosoma & 0.51 & 6 & $\mathbf{M}$ & 0 & - \\
\hline Hydroptila & -0.09 & 3 & 1 & 4 & $\mathrm{~T}$ \\
\hline Leucotrichia & 0.55 & 6 & $\mathbf{M}$ & 4 & $\mathrm{~T}$ \\
\hline Arctopsyche grandis & -0.74 & 0 & $\mathbf{I}$ & 4 & - \\
\hline Cheumatopsyche & 0.59 & 6 & $\mathbf{M}$ & 4 & $T$ \\
\hline Ceratopsyche & 0.33 & 5 & $\mathbf{M}$ & 4 & - \\
\hline Lepidostoma & -0.69 & 1 & 1 & 1 & 1 \\
\hline Apatania & -0.61 & 1 & 1 & 4 & $\mathbf{I}$ \\
\hline Rhyacophila brunnea & -0.61 & 1 & 1 & 0 & I \\
\hline Rhyacophila vaccua & -0.57 & 1 & 1 & 0 & I \\
\hline Petrophila & 0.80 & 7 & $\mathrm{~T}$ & 5 & 1 \\
\hline Heterlimnius & -0.14 & 3 & 1 & 4 & - \\
\hline Narpus & -0.24 & 3 & 1 & 4 & - \\
\hline Optioservus & 0.05 & 4 & $M$ & 4 & $\mathrm{~T}$ \\
\hline Zaitzevia & 0.06 & 4 & $M$ & 4 & $\mathrm{~T}$ \\
\hline Bezzia & -0.54 & 1 & $\mathbf{I}$ & 6 & - \\
\hline Microtendipes & -0.06 & 3 & $\mathbf{I}$ & 8 & - \\
\hline Paratanytarsus & 0.35 & 5 & $M$ & 6 & - \\
\hline Polypedilum & 1.28 & 9 & $T$ & 8 & - \\
\hline Rheotanytarsus & 0.18 & 4 & $M$ & 6 & - \\
\hline Tanytarsus & -0.06 & 3 & I & 6 & - \\
\hline Brillia & -0.72 & 1 & $\mathbf{I}$ & 6 & - \\
\hline Cardiocladius & 0.30 & 5 & $M$ & 6 & - \\
\hline Cricotopus & 0.44 & 6 & M & 6 & 1 \\
\hline Eukiefferiella & 0.06 & 4 & M & 6 & - \\
\hline Orthocladius & 0.46 & 6 & M & 6 & - \\
\hline Thienemanniella & 1.45 & 10 & $\mathbf{T}$ & 6 & - \\
\hline Thienemannimyia & -0.09 & 3 & I & 6 & - \\
\hline Chelifera & -0.40 & 2 & I & 6 & - \\
\hline Hemerodromia & 1.12 & 8 & $T$ & 6 & - \\
\hline Pericoma & -0.65 & 1 & I & 10 & - \\
\hline Glutops & -0.64 & 1 & I & 6 & - \\
\hline Simulium & 0.64 & 6 & $M$ & 6 & - \\
\hline Antocha & -0.28 & 2 & 1 & 3 & - \\
\hline Dicranota & -0.84 & 0 & I & 3 & - \\
\hline Hexatoma & -0.79 & 0 & 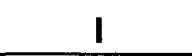 & 3 & - \\
\hline
\end{tabular}


The environmental preferences of invertebrates were also compared with tolerances developed for Western Montane streams by Robert Wisseman of Aquatic Biology Associates, Corvallis, Oreg. (Mark Munn, U.S. Geological Survey, written commun., 1996). Wisseman rates selected invertebrate fauna as either tolerant or intolerant. For the purposes of this comparison, intolerant taxa were defined as those with an agricultural tolerance score of $<5$, and tolerant taxa are those with a score $\geq 5$. Twenty-eight taxa could be compared on this basis (table 20) of which 20 were consistent and only 8 were inconsistent with Wisseman's determinations. The mayfly Tricorythodes, the moth Petrophila, and the midge Cricotopus were rated by the composite agricultural index as more tolerant than indicated by the Wisseman rating. Conversely, two tubificid worms (Aulodrilus americanus and Telmatodrilus vejdovskyi), a caddisfly (Hydroptila) and two elmid beetles (Optioservus and Zaitzevia) were rated as less tolerant by the composite agricultural index. The high degree of correspondence between the composite index derived from CCA and Wisseman's tolerance rankings was not anticipated because the methods used to determine the tolerance rankings were very different and Wisseman's tolerances are based on a broader distribution of sites that encompass a broader array of possible effects than the more limited data from the Yakima River Basin.

The environmental preferences of algae followed a pattern similar to those exhibited by fish and invertebrates (table 21). Twenty-three algal taxa constituted a community that preferred higher elevation, cold-water streams with low levels of agriculture. Sixteen taxa preferred lower elevation, warm-water streams with moderate to high levels of agriculture. Both communities were composed almost exclusively of diatoms, but the community associated with higher elevations and lower levels of agriculture had more blue-green, green, and red algae. Major differences between the two communities occur in their autecological composition. The community associated with higher elevations and lower levels of agriculture contained the majority of the cosmopolitan (72 percent compared to 17 percent), oligothermal ( 100 percent compared to 0 percent), and nitrogen-fixing ( 75 percent compared to 0 percent) algal taxa. The community associated with lower elevations and higher levels of agriculture contained more eutrophic ( 46 percent compared to 9 percent) and halophilic ( 100 percent compared to 0 percent) taxa. Sixteen algal taxa did not show strong preferences for elevation or indicators of agriculture. The majority of these taxa (63 percent) were classified as eutrophic in the literature, and the autecological composition of this group closely approximated that of the community associated with lower elevations and higher levels of agriculture. Two taxa (Cymbella mexicana and C. cistula) exhibited a strong preference for large rivers (drainage basin area), lower elevations, and low levels of agriculture. In contrast, 8 taxa (Nitzschia frustulum var. perminuta, Synedra rumpens, the red alga Audouinella hermanii, Chlamydomonas sp., Diatoma hiemale, Gomphonema subclavatum, Hannaea arcus, and Ulothrix sp.) exhibited a strong preference for small streams, high elevations, and low levels of agriculture.

The environmental preferences exhibited by fish, invertebrates, and algae reveal the overriding influence of elevation on the distribution of biota in the Yakima River Basin. Preferences for substrate size and canopy closure have a strong positive association with preferences for elevation, whereas preferences for stream size (drainage basin area) and indicators of agricultural intensity (NPAI and pesticide indices) have a strong negative association. The environmental preferences of fish, invertebrates, and algae describe two major community types: (1) a community associated with cold, nutrient-poor, mid- to high-elevation streams with low levels of agriculture and (2) a community associated with warmer, more nutrient-rich, mid- to low-elevation streams with mid- to high-levels of agriculture. The first community type is associated with sites that lie in the Cascades and Eastern Cascades ecoregions. The second community type is associated with sites in the Columbia Basin ecoregion, including largeriver sites. These results suggest that management of water quality in the Yakima River Basin needs to take into account the large differences in environmental characteristics between streams in the Cascades and Eastern Cascades and those in the Columbia Basin.

The level of agricultural intensity (NPAI index) preferred by invertebrates and algae (species optima) displayed a strong negative correlation with the optima for elevation (Spearman rho $=-0.84$ for invertebrates and -0.87 for algae, $\mathrm{p}<0.05$ ). Consequently, some of the differences in species tolerances that are ascribed to agriculture may, at least in part, arise from differences in elevation and concomitant changes in temperature, precipitation, vegetation and other climatic factors that affect the distribution of organisms within the basin. Stoneflies provide an example of a group of organisms with generally low agricultural tolerance and distributions shown to be directly related to elevation (fig. 6). Therefore, it is not surprising that few stoneflies show up at low-elevation sites even where agricultural impacts are fairly low (Naches River at North Yakima). The effect of elevation can be reduced by 
examining water-quality relations separately for each of the three site groups (Cascades and Eastern Cascades, Columbia Basin, and large-rivers) defined in the ordinations rather than across the entire basin.

\section{Table 21. Environmental optima for algae derived from the canonical correspondence analysis}

[Optima were determined by projecting the species scores in the canonical correspondence analysis onto the axis representing the environmental variable or index. The projected scores have been multiplied by 10 and rounded to the nearest whole number. Large positive values indicate that the species optima are associated with high levels of the environmental variable or index; large negative values indicate that optima are associated with low levels.]

\begin{tabular}{|c|c|c|c|c|c|c|c|c|c|}
\hline \multirow[b]{2}{*}{ Taxon } & \multirow[b]{2}{*}{ Elevation } & \multirow[b]{2}{*}{$\begin{array}{c}\text { Substrate } \\
\text { size }\end{array}$} & \multirow[b]{2}{*}{$\begin{array}{l}\text { Canopy } \\
\text { closure }\end{array}$} & \multirow[b]{2}{*}{$\begin{array}{c}\text { Drainage } \\
\text { area }\end{array}$} & \multirow[b]{2}{*}{$\begin{array}{l}\text { Metals } \\
\text { index }\end{array}$} & \multirow[b]{2}{*}{$\begin{array}{l}\text { NPAI } \\
\text { index }\end{array}$} & \multicolumn{3}{|c|}{ Pesticide indices } \\
\hline & & & & & & & $\begin{array}{c}\text { Filtered } \\
\text { water }\end{array}$ & $\begin{array}{l}\text { Suspended } \\
\text { sediment }\end{array}$ & $\begin{array}{l}\text { Fish } \\
\text { tissue }\end{array}$ \\
\hline \multicolumn{10}{|c|}{ High elevation, cold-water streams with little agricultural influence } \\
\hline $\begin{array}{c}\text { Nitzschia frustulum var. } \\
\text { perminuta }\end{array}$ & 12 & 10 & 11 & -10 & 4 & -9 & -7 & -8 & -12 \\
\hline Synedra rumpens & 12 & 11 & 12 & -10 & 4 & -10 & -8 & -8 & -12 \\
\hline Audouinella hermanii & 12 & 10 & 12 & -11 & 3 & -9 & -8 & -8 & -12 \\
\hline Chlamydomonas sp. & 11 & 10 & 10 & -9 & 4 & -9 & -8 & -8 & -11 \\
\hline Diatoma hiemale & 11 & 10 & 11 & -10 & 4 & -9 & -7 & -8 & -11 \\
\hline Gomphonema subclavatum & 11 & 10 & 9 & -7 & 6 & -10 & -9 & -9 & -11 \\
\hline Hannaea arcus & 11 & 10 & 10 & -9 & 4 & -9 & -7 & -8 & -11 \\
\hline Ulothrix sp. & 10 & 10 & 9 & -7 & 5 & -9 & -8 & -8 & -10 \\
\hline Amphora ovalis var. pediculus & 10 & 7 & 11 & -11 & -1 & -5 & -4 & -4 & -10 \\
\hline Amphipleura pellucida & 9 & 9 & 8 & -6 & 6 & -9 & -8 & -8 & -9 \\
\hline Rhopalodia gibba & 8 & 8 & 6 & -4 & 6 & -8 & -8 & -8 & -8 \\
\hline Cymbella affinis & 6 & 5 & 6 & -6 & 1 & -5 & -4 & -4 & -6 \\
\hline Epithemia adnata & 6 & 6 & 6 & -5 & 3 & -6 & -5 & -5 & -6 \\
\hline Nostoc sp. & 5 & 5 & 5 & -4 & 2 & -4 & -3 & -4 & -5 \\
\hline Achnanthidium lanceolatum & 5 & 5 & 5 & -4 & 2 & -5 & -4 & -4 & -5 \\
\hline Frustulia rhomboides & 5 & 4 & 5 & -5 & 0 & -3 & -2 & -2 & -5 \\
\hline Aulacoseira italica & 4 & 6 & 1 & 1 & 8 & -7 & -8 & -8 & -4 \\
\hline Navicula radiosa var. tenella & 4 & 3 & 5 & -6 & -1 & -2 & -1 & -1 & -4 \\
\hline Nitzschia linearis & 4 & 2 & 5 & -5 & -1 & -2 & -1 & -1 & -4 \\
\hline Mougeotia sp. & 3 & 2 & 4 & -3 & 0 & -2 & -1 & -1 & -3 \\
\hline Fragilaria mazamaensis & 3 & 4 & 2 & 0 & 5 & -5 & -5 & -5 & -3 \\
\hline Fragilaria vaucheriae & 3 & 2 & 4 & -5 & -2 & -1 & 0 & 0 & -3 \\
\hline Gomphonema angustatum & 3 & 2 & 3 & -3 & 0 & -2 & -2 & -2 & -3 \\
\hline \multicolumn{10}{|c|}{ Lower elevation, warm-water streams with little agricultural influence } \\
\hline Oscillatoria sp. & 2 & 2 & 1 & -1 & 2 & -2 & -2 & -2 & -2 \\
\hline Epithemia sorex & 2 & 4 & 0 & 2 & 6 & -5 & -6 & -5 & -2 \\
\hline Gomphonema dichotomum & 2 & 0 & 3 & -4 & -3 & 1 & 2 & 1 & -2 \\
\hline Synedra ulna & 1 & 1 & 0 & 0 & 2 & -1 & -2 & -2 & -1 \\
\hline Achnanthidium minutissimum & 0 & 1 & 0 & 1 & 1 & -1 & -1 & -1 & 0 \\
\hline $\begin{array}{l}\text { Cocconeis placentula var. } \\
\text { euglypta }\end{array}$ & 0 & 0 & 0 & 0 & 0 & 0 & 0 & 0 & 0 \\
\hline Encyonema minutum & 0 & 0 & -1 & 1 & 0 & 0 & 0 & 0 & 0 \\
\hline Gomphoneis herculeana & 0 & 0 & -1 & 2 & 2 & -1 & -1 & -1 & 0 \\
\hline
\end{tabular}


Table 21. Environmental optima for algae derived from the canonical correspondence analysisContinued

\begin{tabular}{|c|c|c|c|c|c|c|c|c|c|}
\hline \multirow[b]{2}{*}{ Taxon } & \multirow[b]{2}{*}{ Elevation } & \multirow[b]{2}{*}{$\begin{array}{c}\text { Substrate } \\
\text { size }\end{array}$} & \multirow[b]{2}{*}{$\begin{array}{l}\text { Canopy } \\
\text { closure }\end{array}$} & \multirow[b]{2}{*}{$\begin{array}{c}\text { Drainage } \\
\text { area }\end{array}$} & \multirow[b]{2}{*}{$\begin{array}{c}\text { Metals } \\
\text { index }\end{array}$} & \multirow[b]{2}{*}{$\begin{array}{l}\text { NPAI } \\
\text { index }\end{array}$} & \multicolumn{3}{|c|}{ Pesticide indices } \\
\hline & & & & & & & $\begin{array}{c}\text { Filtered } \\
\text { water }\end{array}$ & $\begin{array}{l}\text { Suspended } \\
\text { sediment }\end{array}$ & $\begin{array}{l}\text { Fish } \\
\text { tissue }\end{array}$ \\
\hline Nitzschia dissipata & 0 & 0 & 0 & 0 & 0 & 0 & 0 & 0 & 0 \\
\hline Nitzschia paleacea & 0 & 0 & 0 & 1 & 0 & 0 & 0 & 0 & 0 \\
\hline Gomphonema parvulum & -1 & -3 & 1 & -3 & -6 & 4 & 5 & 5 & 1 \\
\hline Melosira varians & -2 & -2 & -1 & 1 & -2 & 2 & 2 & 2 & 2 \\
\hline Navicula capitatoradiata & -2 & -1 & -2 & 2 & 0 & 1 & 1 & 1 & 2 \\
\hline Navicula viridula & -2 & -3 & -1 & 1 & -2 & 3 & 3 & 3 & 2 \\
\hline Nitzschia frustulum & -2 & -2 & -3 & 3 & 0 & 2 & 1 & 1 & 2 \\
\hline Nitzschia palea & -2 & -1 & -2 & 2 & 0 & 1 & 1 & 1 & 2 \\
\hline \multicolumn{10}{|c|}{ Lower elevation, warm-water streams with moderate to high levels of agriculture } \\
\hline Cymbella mexicana & -3 & 3 & -8 & 12 & 12 & -5 & -7 & -7 & 3 \\
\hline Diatoma vulgare & -3 & -2 & -3 & 2 & -1 & 2 & 2 & 2 & 3 \\
\hline $\begin{array}{c}\text { Navicula menisculus var. } \\
\text { upsaliensis }\end{array}$ & -3 & -3 & -3 & 3 & 0 & 2 & 2 & 2 & 3 \\
\hline Rhoicosphenia curvata & -3 & -3 & -2 & 2 & -2 & 3 & 2 & 2 & 3 \\
\hline Surirella angusta & -3 & -4 & -1 & 0 & -4 & 4 & 4 & 4 & 3 \\
\hline Cocconeis pediculus & -4 & -4 & -2 & 1 & -4 & 5 & 5 & 5 & 4 \\
\hline Cyclotella meneghiniana & -4 & -2 & -6 & 6 & 3 & 1 & 0 & 0 & 4 \\
\hline Cymbella cistula & -5 & 0 & -10 & 12 & 9 & -2 & -5 & -4 & 5 \\
\hline Gomphonema sp. 1 & -5 & -4 & -5 & 5 & -1 & 4 & 3 & 3 & 5 \\
\hline Staurosira construens & -5 & -4 & -5 & 5 & -1 & 3 & 2 & 2 & 5 \\
\hline Amphora perpusilla & -6 & -7 & -5 & 3 & -5 & 7 & 6 & 7 & 6 \\
\hline Reimeria sinuata & -6 & -5 & -6 & 5 & -2 & 5 & 4 & 4 & 6 \\
\hline Navicula luzonensis & -7 & -8 & -4 & 2 & -8 & 8 & 8 & 8 & 7 \\
\hline Navicula tripunctata & -8 & -8 & -8 & 6 & -4 & 7 & 6 & 6 & 8 \\
\hline Nitzschia inconspicua & -8 & -10 & -5 & 2 & -9 & 10 & 10 & 10 & 8 \\
\hline Luticola mutica & -10 & -10 & -8 & 6 & -7 & 10 & 9 & 10 & 10 \\
\hline
\end{tabular}

\section{Community Metrics and Environmental Characteristics}

Correlation and regression (stepwise) analyses were used to examine relations between environmental variables (tables 3 and 8) and many of the metrics commonly used to summarize fish, invertebrate, and algal communities. An understanding of the relations between community metrics and environmental variables is important in developing, applying, and interpreting multimetric indices of community condition that rely on aggregations of community metrics. These multimetric community condition indices are an important means of examining responses of communities to specific water-quality issues, such as agriculture, that cannot be addressed by multivariate analyses, which are best suited to identifying gradients that affect the distribution of species over large areas. 
Fish

Two of the metrics that compose the multimetric fish community condition index (table 6) were significantly related to environmental variables. Percentage composition of tolerant individuals directly correlated with water temperature and turbidity $\left(r^{2}=0.74, p=0.003\right)$ and percentage composition of omnivores/herbivores directly correlated with canopy cover and increasing agricultural intensity (NPAI index) $\left(r^{2}=0.84, p=0.01\right)$. The other two metrics in the condition index, percentage of non-native individuals and percentage of external anomalies, were not significantly correlated with any of the physical and chemical variables listed in table 3 or with the indices of physical and chemical conditions listed in table 8.

Fish taxa richness, a community metric that was not used in the multimetric fish community condition index, was significantly related to stream size, as defined by drainage area. In some stream systems, the number of fish taxa can be expected to increase as stream size increases. This pattern may be reversed as a result of the cumulative effects of upstream environmental degradation or alterations in flow from water removal. Examination of the relation between fish taxa richness and drainage area suggested separate, positive relations for the relatively unimpaired Cascades and Eastern Cascades site group and the large-river site group (fig. 9). However, this relation did not apply in the Columbia Basin site group where intensive agriculture appears to disrupt the natural relation between drainage area and taxa richness.

\section{Site groupings: $\square$ Cascades Eastern Cascades $\diamond$ Columbia Basin $O$ Large River}

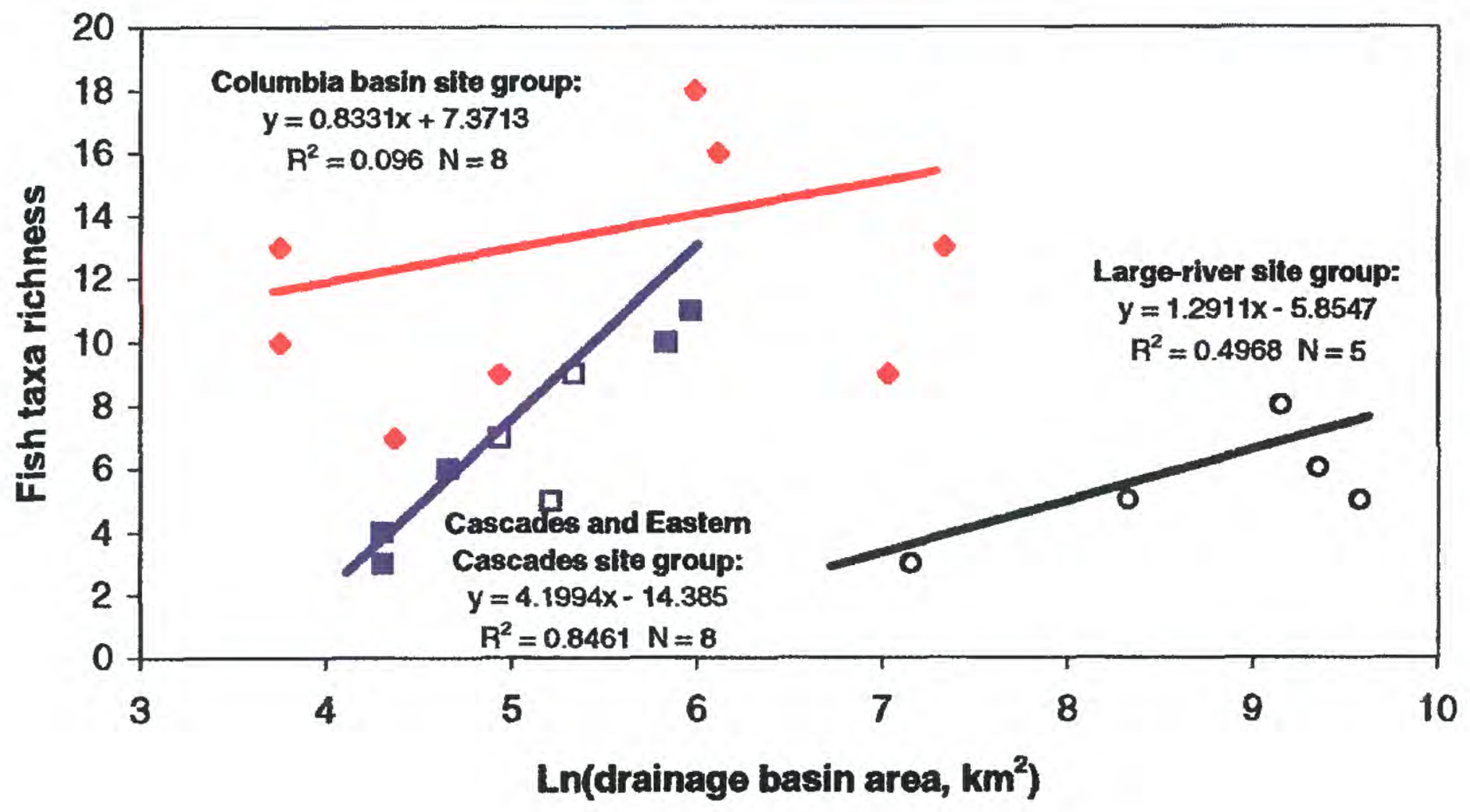

Figure 9. Relation between fish taxa richness and logarithm of drainage area $\left(\mathrm{km}^{2}\right)$ for sites in the Yakima River Basin, Washington. 


\section{Invertebrates}

Stepwise regression of invertebrate community metrics (table 4) showed that the NPAI index, canopy closure (a surrogate for elevation), total nitrogen, proportion of basin area in rangeland, and concentration of manganese in bed sediment provided the best $\left(\mathrm{r}^{2}=0.96\right)$ prediction of total taxa richness, a key indicator of invertebrate community condition (Barbour and others, 1996). The NPAI index and degree of canopy closure (CANOPY) dominated this regression and predicted both taxa richness and EPT richness almost as well as the five variable model. The relation between richness and the NPAI index and degree of canopy closure is indicated by the following regression equations:

$$
\begin{aligned}
& \ln [\text { Richness }]=3.6992-0.0083 * \mathrm{NPAI}+0.0090 * \mathrm{CANOPY}, \text { adjusted } \mathrm{r}^{2}=0.88, \mathrm{p}<0.001 \\
& \ln [\text { EPT richness }]=2.9837-0.0145 * \mathrm{NPAI}+0.0117 * \text { CANOPY, adjusted } \mathrm{r}^{2}=0.85, \mathrm{p}<0.001 \\
& \text { where Richness is the number of taxa of invertebrates, } \\
& \text { NPAI is the non-pesticide agricultural intensity index, } \\
& \text { CANOPY is the percentage of canopy closure, } \\
& \text { EPT is the number of taxa of Ephemeroptera (mayflies), Plecoptera (stoneflies), and } \\
& \text { Trichoptera (caddisflies). }
\end{aligned}
$$

Canopy closure and the NPAI index take into account the major natural differences between streams in the Columbia Basin and the Cascades and Eastern Cascades site group (for example, elevation directly effects climatic conditions such as temperature, precipitation, and evapotranspiration which indirectly effects canopy closure) and the effects of agriculture (NPAI index) on Columbia Basin streams. Invertebrate taxa richness (total and EPT) also was strongly related to the overall index of disturbance (table 8 ), which primarily represents disturbances related to agricultural land use:

$$
\begin{aligned}
& \ln [\text { Richness }]=4.0754-0.5524 * \text { DISTURB, adjusted } \mathrm{r}^{2}=0.84, \mathrm{p}<0.001 \\
& \ln [\text { EPT richness }]=3.5670-0.9738 * \text { DISTURB } \mathrm{r}^{2}=0.86, \mathrm{p}<0.001
\end{aligned}
$$

$\begin{array}{ll}\text { where: } & \text { Richness } \\ & \text { DISTURB } \\ & \text { EPT }\end{array}$

is the number of taxa of invertebrates, is the index of disturbance (table 8), is the number of taxa of Ephemeroptera (mayflies), Plecoptera (stoneflies), and Trichoptera (caddisflies).

Plotnikoff (1995) also reported significant relations between invertebrate taxa richness (total and EPT) in the Cascades and Columbia Basin ecoregions and stream disturbance, land use, hydrology (flow, average current velocity), and stream morphology (substrate availability, wetted width, bankfull width, wetted width/bankfull width). The correlations that he reported were not nearly as strong as those observed for the NPAI index, canopy closure, and the overall disturbance index, probably because his work did not include the range of agricultural conditions encompassed in the present study. Many of the metrics derived from invertebrate abundances (table 4) were significantly correlated with one or more environmental variables (for example, disturbance index) but these relationships were not as useful for predicting metric values as were the relationships described for taxa richness.

$$
\text { Algae }
$$

Taxa richness and abundance of benthic algae did not show strong relations with land-use or indicators of chemical water quality. However, chlorophyll concentrations and algal community structure (relative abundance of autecological groups) were significantly correlated with land-use and indicators of water quality. Chlorophyll $a$ and $b$ were positively correlated with indicators of agricultural disturbance such as the proportion of stream flow originating from irrigation (Spearman rho $>0.41, p=0.05$ ), nutrient enrichment (total nitrogen, total ammonia + organic nitrogen, dissolved nitrite and nitrate, total phosphorus, and dissolved ortho-phosphate; Spearman rho $>0.43, p<0.03$ ), agricultural intensity (NPAI index, Spearman rho $>0.60, p<0.01$ ), pesticide contamination (pesticides in filtered water, suspended sediment, and fish tissue; Spearman rho $>0.41, \mathrm{p}<0.04$ ), and substrate 
embeddedness (Spearman rho $>0.56, \mathrm{p}<0.01$ ). Chlorophyll concentrations were negatively correlated (Spearman rho $>0.43, \mathrm{p}<0.02$ ) with elevation. Collectively, this suggests that agriculture has a strong influence on algal community structure and standing crops.

The relative abundances of autecological guilds (eutrophic, facultative nitrogen-heterotrophic, halophilic, siltation-tolerant, nitrogen-fixing, and oligotrophic and oligothermal algae) as defined by Schoeman (1973), Lowe (1974), and Van Dam and others (1994) (table 16) were also significantly correlated with indicators of agriculture and elevation. The relative abundance of most tolerant guilds (nitrogen heterotrophic, halophilic, eutrophic, and siltation tolerant forms) were positively correlated with physical and chemical characteristics that are indicative of agriculture (for example, NPAI index, rho $>0.47, \mathrm{p}<0.02$; nutrients, rho $>0.43, \mathrm{p}<0.03$; turbidity, rho $>0.39$, $\mathrm{p}<0.05$; conductivity, rho $>0.50, \mathrm{p}<0.02$; and substrate embeddedness, rho $>0.50, \mathrm{p}<0.05$ ) and negatively correlated with physical and chemical characteristics indicative of unaffected headwater streams (for example, canopy, rho $=-0.56, \mathrm{p}=0.01$ and elevation, rho $-0.74, \mathrm{p}<0.001$ ).

Relative abundances of common tolerant algae (eutrophic, facultative nitrogen heterotrophs, and siltation tolerant) were positvely correlated with indicators of agricultural intensity. Conversely, intolerant algae (nitrogen fixers, oligotrophic/oligothermal) were negatively correlated with agricultural intensity. Eutrophic taxa were positively correlated with the index of agricultural intensity (NPAI index, rho $=0.47, p<0.001$ ) and components of this index (total nitrogen, rho $=0.45, \mathrm{p}<0.05 ; \mathrm{NO}_{2}+\mathrm{NO}_{3}$, rho $=0.61, \mathrm{p}<0.001$; total phosphorus, rho $=0.56$, $\mathrm{p}<0.001$ ). However, the relative abundances for 5 of 19 species assigned to the eutrophic guild based on published literature were not significantly correlated with agricultural intensity or concentrations of nitrogen or phosphorus (table 22). Relative abundances of 3 of 4 common facultative nitrogen-heterotrophic algae also were positively correlated with the index of agricultural intensity (NPAI index; rho $=0.57 ; \mathrm{p}<0.001$ ) and components of this index (total nitrogen, rho $=0.57, \mathrm{p}<0.001$; dissolved $\mathrm{NH}_{4}$, rho $=0.40, \mathrm{p}<0.05$; and $\mathrm{NO}_{2}+\mathrm{NO}_{3}$ nitrogen, rho $=0.69$, $\mathrm{p}<0.001)$. The relative abundances of halophilic algae were positively correlated with specific conductance (rho $=$ $0.64 ; \mathrm{p}<0.001$ ) and agricultural intensity (NPAI index; rho $=0.67 ; \mathrm{p}<0.001$ ). Siltation-tolerant algae included two common taxa (Luticola mutica and Nitzschia linearis) whose abundances were positively correlated with water turbidity and substrate embeddedness. Luticola mutica, which has been reported previously from soils (Hustedt, 1937-38), was positively correlated with agricultural intensity (NPAI index, rho $=0.55 ; \mathrm{p}<0.001$ ), whereas Nitzschia linearis was not correlated with agricultural intensity.

\section{Table 22. Numbers of taxa in each autecological guild that were correlated with indicators of agricultural intensity}

[Taxa were assigned to autecological guilds based on published literature. Spearman rank correlation between algal abundance and the NPAI index were determined for the 55 most common algal taxa. A taxon may below to multiple autecological guilds.]

\begin{tabular}{lcccc}
\hline & \multicolumn{3}{c}{ Number of taxa significantly correlated with NPAI index or nutrients } \\
\cline { 2 - 5 } \multicolumn{1}{c}{ Autecological group } & Positive & Negative & None & Total \\
\hline Eutrophic & 11 & 1 & 5 & 17 \\
Nitrogen fixer & 0 & 3 & 1 & 4 \\
Nitrogen heterotroph & 4 & 0 & 1 & 5 \\
Halophilic & 4 & 0 & 1 & 5 \\
Silt tolerant & 1 & 0 & 1 & 2 \\
Cosmopolitan & 2 & 7 & 10 & 19 \\
Oligotrophic/Oligothermal & 0 & 3 & 1 & 4 \\
Unknown & 0 & 0 & 3 & 3 \\
\hline
\end{tabular}

The relative abundances of common intolerant algae (nitrogen fixers, oligotrophic and oligothermal) were correlated with physical and chemical factors that are indicative of non-agriculturally affected sites; positively correlated with canopy closure (shade-adapted species) and elevation (rho $>0.68 ; \mathrm{p}<0.001$ ) and negatively correlated with water temperature (rho $=-0.72 ; p<0.001)$ and turbidity (rho $<-0.45 ; p<0.05)$. Relative abundances of common nitrogen-fixing algae were negatively correlated with concentrations of total nitrogen (rho $=$ 
$-0.54 ; \mathrm{p}<0.001)$, dissolved $\mathrm{NH}_{4}($ rho $=-0.43 ; \mathrm{p}<0.05)$, total $\mathrm{NH}_{4}+$ organic nitrogen (rho $\left.=-0.48 ; \mathrm{p}<0.001\right)$, and $\mathrm{NO}_{2}+\mathrm{NO}_{3}$ nitrogen (rho $=-0.69 ; \mathrm{p}<0.001$ ), as well as agricultural intensity (NPAI index; rho $-0.54 ; \mathrm{p}<0.001$ ). The relative abundances of oligotrophic and oligothermal algae were negatively correlated with concentrations of total nitrogen (rho $=-0.65 ; \mathrm{p}<0.001$ ), total NH4+organic nitrogen (rho $=-0.47 ; \mathrm{p}<0.001$ ), NO2+NO3 nitrogen (rho $=-0.68 ; p<0.001$ ), total and dissolved phosphorus (rho $<-0.50 ; p<0.001$ ), specific conductance (rho $=-0.63$; $\mathrm{p}<0.001$ ), and agricultural intensity (NPAI index; rho $=-0.65 ; \mathrm{p}<0.001$ ). Many of these taxa have been classified previously as soft-water, shade-tolerant, cool-water, and(or) acidophilic (that is, occurring at a $\mathrm{pH}$ of around 7 with best development below 7; Hustedt, 1937-38; Lowe, 1974).

Correlations between the relative abundances of individual algal taxa and indicators of agricultural intensity (NPAI index and nutrient concentrations) were used to determine how well autecological guilds derived from the literature represented responses to agricultural intensity. Only the common taxa, those found at 5 or more sites, were used for this comparison. Taxa not significantly correlated (Spearman's rank correlation) to the NPAI index or nutrient concentrations were classified as cosmopolitan ( 21 of the 55 common algal species, table 15). In this manner, six (Cyclotella meneghiniana, Encyonema minutum, Gomphonema dichotomum, Gomphonema parvulum, Nitzschia linearis, and Synedra ulna) identified as tolerant of nutrient enrichment (eutrophic taxa and nitrogen heterotrophs, table 15) in the literature (Van Dam and others, 1994; Lowe, 1974) were reclassified as cosmopolitan. Over half (11 of 21) of the algal taxa classified from the literature as cosmopolitan (table 15) were also classified as cosmopolitan based on correlations with the NPAI index and nutrient concentrations. However, the abundances of two common cosmopolitan taxa (Cocconeis pediculus and Cocconeis placentula var. euglypta) were positively correlated with nutrient concentrations and were reclassified as tolerant of agriculture. Seven taxa (Ulothrix sp., Achnanthidium lanceolatum, Amphipleura pellucida, Diatoma hiemale, Gomphonema subclavatum, Nitzschia frustulum var. perminuta, and Synedra rumpens) that were classified as cosmopolitan in the literature were negatively correlated with the NPAI index or components of this index and were reclassified as intolerant of agriculture. Two species (Epithemia sorex and Fragilaria mazamaensis) that were classified as intolerant based on autecological guilds (nitrogen fixer and oligotrophic/oligothermal, respectively) were reclassified as cosmopolitan because their relative abundances were not significantly correlated with indicators of agriculture. One taxon (Chlamydomonas sp.) identified as tolerant in the literature (eutrophic) was reclassified as intolerant because it was negatively correlated with nutrient concentrations. Overall, 14 algal taxa were reclassified as less tolerant and 4 taxa were reclassified as more tolerant. Classification of algal tolerances based on correlations with indicators of agricultural intensity provides an additional method to determine site conditions.

\section{Condition of Fish Communities}

The multimetric approach taken to characterize the condition of fish communities was limited to four metrics that represent a subset of those used in most versions of the IBI. These metrics characterized tolerance, trophic association, origin (native or introduced), and health of each fish species (table 5) and were based on classifications of Hughes and Gammon (1987) and Chandler and others (1993). Analysis of tolerant and trophic composition indicated that fish community structure at Umtanum Creek and at sites in the Cascades and Eastern Cascades ecoregions was composed of few tolerant or omnivore/herbivore individuals (fig. 10). Conversely, fish community structure at Granger and Moxee Drains, Satus Creek at gage, and at main stem river sites (with the exception of Yakima River at Cle Elum) was composed of relatively large numbers of tolerant and omnivore/herbivore individuals. Fish community structure at the remaining sites (Wide Hollow Creek, Satus Creek below Dry Creek, Ahtanum Creek, and Cherry Creek) was composed of relatively large numbers of tolerant individuals and few omnivores/herbivores.

Sites in the Cascades and Eastern Cascades site group rated low on fish-community metrics reflecting environmental degradation (table 23). Of the wadable sites in the Columbia Basin, Umtanum Creek, Ahtanum Creek, and Satus Creek below Dry Creek also were rated as indicating low impairment (table 23). Granger Drain was rated as severely impaired based on metrics reflecting environmental degradation. All other wadable sites in the Columbia Basin were rated as moderately impaired. All large river sites in the Columbia Basin ecoregion, with the exception of Yakima River at Umtanum, were rated as severely impaired. Yakima River at Umtanum was assigned a rating of moderately impaired. Yakima River at Cle Elum, which is located in the Cascades ecoregion, was the only large-river site that was rated as unimpaired. 


\section{Site groupings: $\square$ Cascades Eastern Cascades $\bullet$ Columbia Basin $O$ Large river}

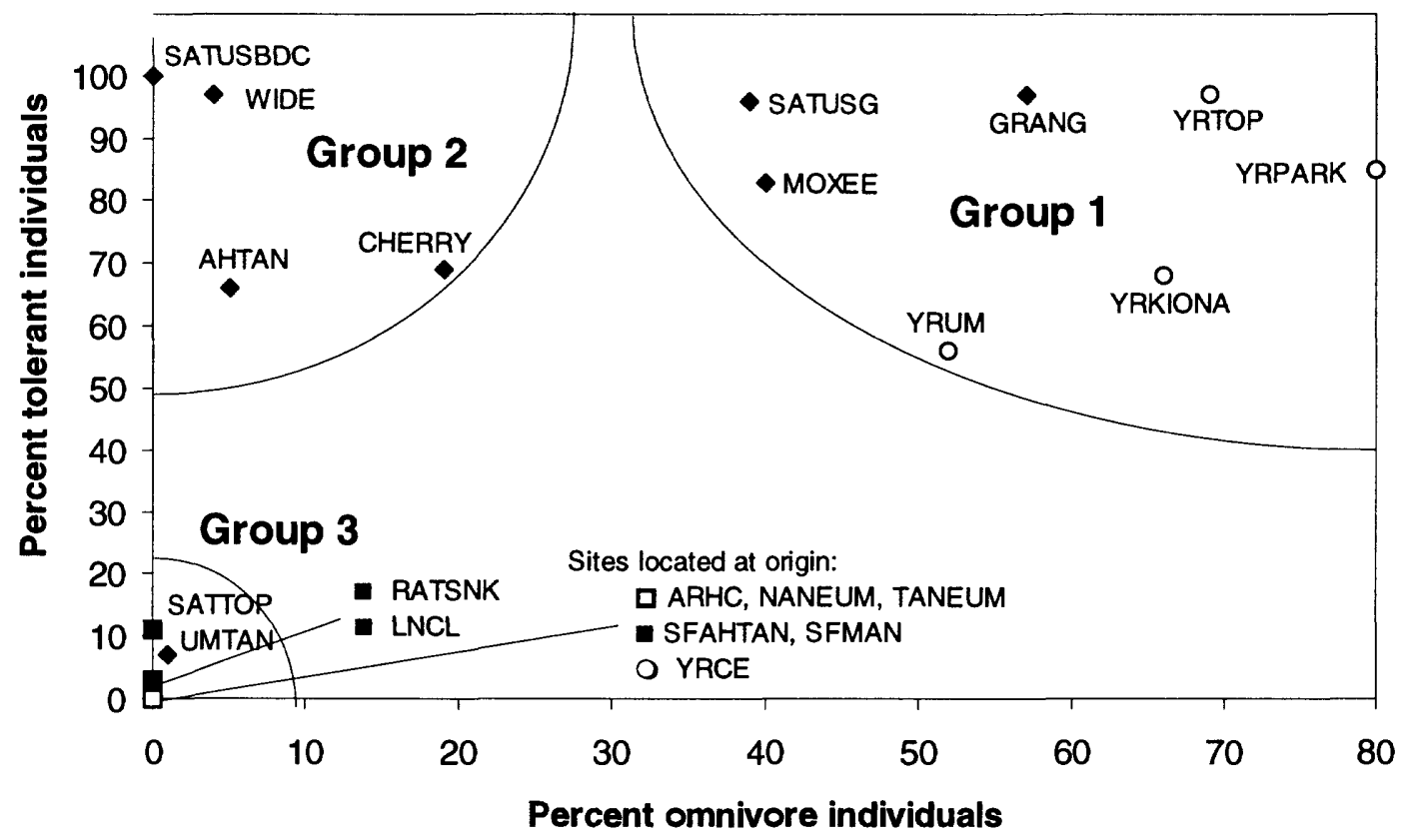

Figure 10. Relation between percentage of fish community abundance composed of species that are omnivorous or herbivorous and species that are tolerant, Yakima River Basin, Washington, 1990. (Site abbreviations are listed in table 1.)

Interpretation of biological condition based on these four metrics may be less responsive in general to a broad spectrum of degradation compared to an IBI based on more extensive metrics. These four metrics are the basis of a conceptual model of fish community response to environmental degradation in warm-water wadable streams (Yoder and Rankin, 1995); thus, interpretation of these metrics may have some limitations when applied to cold-water and large-river sites within the Yakima River Basin. Karr and others (1986) suggested that scoring criteria may vary to reflect differences in stream size and ecoregion, though Hughes and Gammon (1987) argued that where similarities in species ranges occur in the Pacific Northwest, it may not be logical to have separate scoring criteria, particularly for stream size. Also, because of the numerous challenges encountered when developing criteria for large rivers, including sampling concerns and the lack of relatively unaffected sites, there is presently a scarcity of information from which to assess biological expectation and, thereby, refine scoring criteria (Reash, 1995).

Based on the four-metric index of fish community condition, there is no evidence that the fish communities at sites in the Cascades and Eastern Cascades ecoregions are degraded. The lack of external anomalies and dominance of salmonids and sculpins (nearly 90 percent or more of abundance) at sites in the Cascades and Eastern Cascades is indicative of high-quality cold-water streams (Simon and Lyons, 1995). The abundance of tolerant, non-native, and omnivore/herbivores were relatively low to non-existent at these sites.

The multimetric approach to assessing biological condition as applied to sites located in the Columbia Basin site group indicated that the fish community in Granger Drain was in poor condition (severely impaired). The percentage composition of tolerant individuals and omnivore/herbivores combined was the highest of any tributary site sampled. In addition, individuals with external anomalies were noted at this site. The presence of external anomalies may indicate sublethal environmental stresses or chemically contaminated substrates (Meador and others, 
Table 23. Fish community degradation metrics, community degradation scores, and site impairment ratings, Yakima River Basin, Washington, 1990

[HC, Hells Crossing; SF, South Fork; Cr, Creek; nr, near; blw, below; YR, Yakima River.]

\begin{tabular}{|c|c|c|c|c|c|c|c|}
\hline $\begin{array}{l}\text { Station } \\
\text { number }\end{array}$ & Site name & $\begin{array}{c}\text { Anomalies } \\
\text { (percent) }\end{array}$ & $\begin{array}{c}\text { Omnivore/ } \\
\text { herbivores } \\
\text { (percent) }\end{array}$ & $\begin{array}{c}\text { Tolerant } \\
\text { (percent) }\end{array}$ & $\begin{array}{c}\text { Non-native } \\
\text { (percent) }\end{array}$ & $\begin{array}{c}\text { Community } \\
\text { degradation } \\
\text { score } \\
\end{array}$ & $\begin{array}{c}\text { Site } \\
\text { impairment } \\
\text { rating }\end{array}$ \\
\hline \multicolumn{8}{|c|}{ Cascades site group } \\
\hline 12481900 & Taneum Creek & 0 & 0 & 0 & 0 & 4 & low \\
\hline 12483750 & Naneum Creek & 0 & 0 & 0 & 0 & 4 & low \\
\hline 12488250 & American River $\mathrm{HC}$ & 0 & 0 & 0 & 0 & 4 & low \\
\hline \multicolumn{8}{|c|}{ Eastern Cascades site group } \\
\hline 12483190 & SF Manastash Creek & 0 & 0 & 0 & 0 & 4 & low \\
\hline 12487200 & Little Naches River & 0 & 0 & 2 & 0 & 4 & low \\
\hline 12489100 & Rattlesnake Creek & 0 & 0 & 3 & 0 & 4 & low \\
\hline 12500900 & SF Ahtanum Creek & 0 & 0 & 0 & 0 & 4 & low \\
\hline 12507594 & Satus $\mathrm{Cr}$ nr Toppenish & 0 & 0 & 11 & 0 & 4 & low \\
\hline \multicolumn{8}{|c|}{ Columbia Basin site group } \\
\hline 12484440 & Cherry Creek & 0 & 19 & 69 & 5 & 10 & moderate \\
\hline 12484550 & Umtanum Creek & 0 & 1 & 7 & 1 & 4 & low \\
\hline 12500430 & Moxee Drain & 0 & 40 & 83 & 0 & 10 & moderate \\
\hline 12500442 & Wide Hollow Creek & 0 & 4 & 97 & 0 & 10 & moderate \\
\hline 12502500 & Ahtanum Creek & 0 & 5 & 66 & 1 & 8 & low \\
\hline 12505460 & Granger Drain & 6 & 57 & 97 & 0 & 16 & severe \\
\hline 12508500 & Satus Cr blw Dry Creek & 0 & 0 & 100 & 0 & 8 & low \\
\hline 12508620 & Satus Creek at gage & 0 & 39 & 96 & 1 & 10 & moderate \\
\hline \multicolumn{8}{|c|}{ Large-rivers site group } \\
\hline 12479500 & YR at Cle Elum & 0 & 0 & 0 & 0 & 4 & low \\
\hline 12484500 & YR at Umtanum & 0 & 52 & 56 & 0 & 12 & moderate \\
\hline 12503950 & YR at Parker & 13 & 80 & 85 & 5 & 16 & severe \\
\hline 12507525 & YR below Toppenish & 11 & 69 & 97 & 7 & 18 & severe \\
\hline 12510500 & YR at Kiona & 28 & 66 & 68 & 17 & 20 & severe \\
\hline
\end{tabular}

1993a). Granger Drain was characterized by relatively high turbidity, nutrient concentrations, sedimentation (embeddedness), and pesticides in filtered water and suspended sediment. Yoder and Rankin (1995) suggested that the percent composition of omnivorous fish may be an indicator of agricultural and channel modifications. Thus, a combination of physical and chemical factors appear to have contributed to the degraded condition of the fish community at Granger Drain.

In the Columbia Basin site group, Umtanum Creek, Satus Creek below Dry Creek, and Ahtanum Creek revealed little evidence of degradation to the fish community based on qualitative ratings. Moxee Drain, Satus Creek at gage, Cherry Creek, and Wide Hollow Creek were rated as moderately impaired based on fish community structure. These sites were characterized by relatively large numbers of tolerant individuals and large numbers of omnivore/herbivores or non-native individuals. As at Granger Drain, agricultural intensity was rated as high at Moxee Drain and Wide Hollow Creek, suggesting that differences in physical characteristics between these sites may account for differences in community structure. 
Of the large-river sites in the Columbia Basin (Yakima River at Cle Elum is in the Cascades ecoregion), the fish community at Yakima River at Umtanum was rated moderately degraded, whereas Yakima River sites at Parker, Toppenish, and Kiona were rated as highly degraded. With the exception of Yakima River at Umtanum, fish with external anomalies were collected at these sites. Although the use of multimetric approaches for assessing fish condition in large rivers needs further testing and development (Reash, 1995), the presence of external anomalies alone may suggest possible chemical degradation at these sites.

Site rankings based on fish community conditions were closely related to agricultural intensity (NPAI index) (fig. 11). Community condition ratings of 17 of 21 sites (fig. 11) agreed with the NPAI (table 8). Only one site, Moxee Drain, was rated as being in better condition than the NPAI index indicated. Large-river sites where external anomalies were encountered (Yakima River at Parker, Toppenish, and Kiona) were rated as more degraded than indicated by the NPAI index. This close relation between the NPAI index and the condition of fish communities suggests that fish are responding to the environmental factors that are directly affected by agricultural practices and that maintaining fish communities in high quality condition will depend upon how agriculture is managed.

\section{Condition of Benthic Macroinvertebrate Communities}

The condition of benthic macroinvertebrate communities was determined using a multimetric condition index based on 20 community metrics (table 13). This index emphasizes the response of communities to disturbance (disturbance index) throughout the Yakima River Basin and community differences between agriculturally impaired (Granger Drain, Moxee Drain, and Spring Creek) and unimpaired (Satus Creek below Dry Creek and Umtanum Creek) streams of the Columbia Basin site group. Community conditions were ranked relative to conditions at appropriate reference ("least affected") sites within the three site groups (Cascades and Eastern Cascades, Columbia Basin, and large rivers) derived from ordination of the community and physical and chemical data. Dividing the Yakima River Basin into these groups minimized the complicating effects that climate and elevation have on the distribution of organisms. Taneum Creek, Rattlesnake Creek, South Fork Manastash, and Satus Creek near Toppenish were selected to represent reference conditions in the Cascades and Eastern Cascades ecoregions; Satus Creek below Dry Creek and Umtanum Creek were selected to characterize the Columbia Basin; and Naches River at North Yakima and Yakima River at Umtanum were selected to characterize large-river sites. These sites were chosen to represent reference conditions because indicators of impairment were minimal (low index scores, table 8) and each site had high total and EPT taxa richness (table 13) for their respective site groups. Separate multimetric community condition indices were calculated for each reference site. Average and 95 -percent confidence intervals were calculated from these individual estimates and used to characterize variability of the condition estimate.

The multimetric condition index (fig. 12) indicated that invertebrate communities at most sites in the Cascades and Eastern Cascades site group were in good condition (that is, unimpaired), with the exception of North Fork Teanaway River, Naneum Creek, and Little Naches River near Cliffdell. These sites were rated as moderately impaired, probably because they have been harvested for timber within the past 5 years (Stuart McKenzie, U.S. Geological Survey, oral commun., 1995). Metals enrichment is apparent in the Cascades and Eastern Cascades site group (table 8) with three sites (North Fork Teanaway River, Taneum Creek, and South Fork Manastash Creek) having values for the metals index above background levels $(\geq 4.0)$. However, the value of the multimetric condition index does not correspond to the value of the metals index, so it is unlikely that the levels of metals enrichment observed here are affecting the condition of the invertebrate communities. Similarly, the invertebrate community condition index does not correspond to the index of agricultural intensity (NPAI index), which is low at all sites. Community conditions in the Cascades and Eastern Cascades site group are probably related to the intensity of logging, which was not quantified in this study. The confidence intervals around the mean estimates of site conditions indicate a broad overlap in condition suggesting that, from a statistical view, there is little difference in condition among sites in the Cascades and Eastern Cascades site group.

Yakima River at Cle Elum, a large-river site in the Cascades ecoregion, is rated as moderately impaired when community conditions are derived using the four reference sites of the Cascades and Eastern Cascades site group (YRCE ${ }^{1}$, fig. 12). However, when community condition is determined using large-river reference sites (YRCE ${ }^{2}$ ), this site is rated as unimpaired. This difference in condition rating emphasizes the importance of selecting appropriate reference sites for determining community condition. 


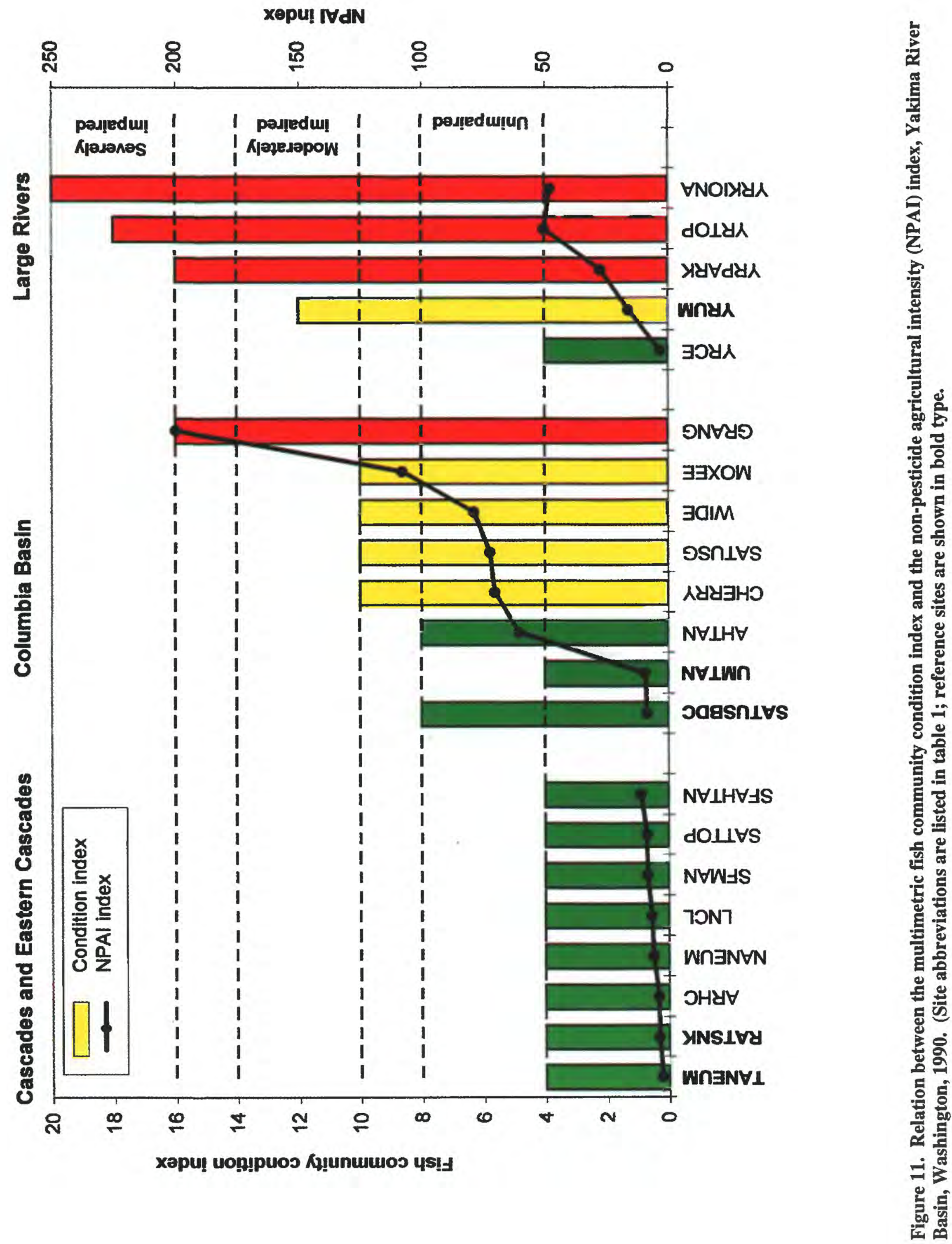



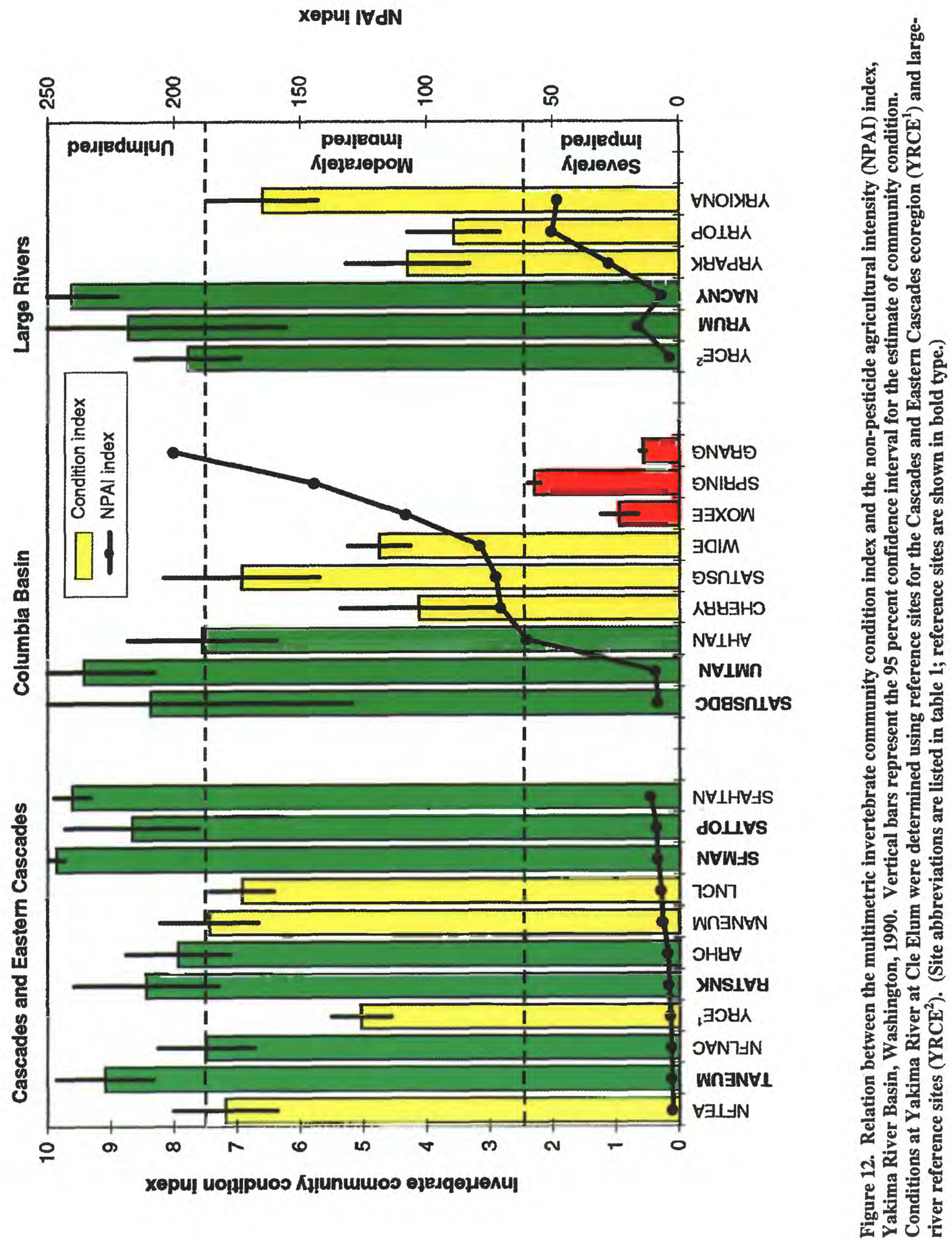
Three sites in the Columbia Basin site group (Granger Drain, Moxee Drain, and Spring Creek) had very low community condition scores (less than 25 percent of reference conditions) indicating substantial impairment and warranting a high level of concern for the invertebrate communities (fig. 12). Sites with high levels of impairment are associated with high levels of pesticides and agricultural impairment (NPAI index) (table 8) which, together with habitat degradation, are probably responsible for the poor conditions at these sites. Two other sites that receive agricultural drainage (Cherry Creek) and agriculture plus urban drainage (Wide Hollow Creek) had multimetric condition indices that indicate a moderate level of impairment. Conditions at these sites are similar based on agricultural intensity (NPAI index), mean community condition scores (multimetric condition index), and the broad overlap of confidence intervals for the multimetric condition index (fig. 12). Satus Creek at gage, which has a level of agricultural intensity (72.5) similar to Cherry Creek (70.7) and Wide Hollow Creek (79.0), was also rated as moderately impaired. However, the value for the multimetric community condition at Satus Creek at gage was higher than at Cherry Creek and Wide Hollow Creek, and the confidence limits did not overlap. The multimetric community condition index indicated better conditions at Satus Creek at gage than at Cherry Creek and Wide Hollow Creek because total (36) and EPT richness (14) were very similar to values measured at Columbia Basin reference sites (Umtanum Creek and Satus Creek below Dry Creek). This difference may relate to differences in pesticide contamination among these three sites. Cherry Creek had the highest score for pesticides in bed sediment (147.2) of all 25 sites and Wide Hollow Creek had the highest score for pesticides in fish tissue (13.1) for these three sites. This may imply that pesticides play a role, but this cannot be confirmed because data for pesticides in bed sediment at Satus Creek at gage were not collected.

Ahtanum Creek and the two Columbia Basin reference sites (Umtanum Creek and Satus Creek below Dry Creek) were ranked as unimpaired, indicating that the condition of invertebrate communities at these sites was very good. The invertebrate community CCA also grouped Ahtanum Creek with Umtanum Creek and Satus Creek below Dry Creek lending further evidence to the high quality of the community at Ahtanum Creek. Total and EPT richness (table 13) were similar at these sites and were the highest values observed in the Columbia Basin site group. Invertebrate communities at Umtanum Creek and Satus Creek below Dry Creek were expected to be of low concern because these sites had low values for agricultural intensity, metals, pesticides, and disturbance. However, the intensity of agriculture at Ahtanum Creek is at least six times greater than that of Umtanum Creek or Satus Creek below Dry Creek and is slightly less than sites that were rated as moderate concern (Cherry Creek, Satus Creek at gage, and Wide Hollow Creek). Values of the disturbance and pesticide indices (except pesticides in fish tissue) at Ahtanum Creek are, with the exception of the two reference sites, the lowest in the Columbia Basin site group, which may explain why this site is unimpaired. However, it is likely that any increase in metals, agricultural intensity, or pesticides could decrease the multimetric condition index value and cause Ahtanum Creek to be rated as moderately impaired. Therefore, Ahtanum Creek is a site where community conditions could rapidly degrade if agricultural intensity or pesticide contamination were to increase even by relatively modest amounts.

Three sites in the large-river site group (Yakima River at Cle Elum, Yakima River at Umtanum, and Naches River at North Yakima) were rated as unimpaired by the invertebrate multimetric community condition index (fig. 12). All other sites in this site group were rated as moderately impaired. The value of the condition index dropped dramatically along the main stem between Yakima River at Umtanum and Yakima River at Parker. This drop was accompanied by large increases in the value of the pesticide indices (pesticides in bed sediment increased from 7.6 to 89.2, pesticides in fish tissue increased from 4.8 to 21.9) and a modest increase in agricultural intensity (16.2 to 27.5), (table 8). The Naches River, which is the major tributary between Umtanum and Parker, was not the source for this decrease in water quality because physical, chemical and biological (invertebrates) conditions near the mouth of the Naches River are very good (unimpaired). What may be influencing community conditions are: (1) hydrologic modifications caused by irrigation and power diversions (Roza Canal, Selah-Moxee Canal, Moxee Canal and Wapato Canal), (2) municipal wastewater discharges (Selah, Yakima, and Moxee City), and (3) irrigation return flows (Wide Hollow Creek, Moxee Drain, and Ahtanum Creek) (fig. 1).

Physical and chemical conditions (NPAI index, disturbance index, and index of pesticides in filtered water, suspended sediment, and fish tissue; table 8) continue to degrade between Yakima River at Parker and Yakima River below Toppenish, probably due to water diversion (Sunnyside Canal), additional municipal wastewater discharges (cities of Zillah, Toppenish, Granger, Wapato), and irrigation return flows (E. Toppenish Drain, Sub-Drain No. 35, Granger Drain, and Marion Drain) that add additional nutrients, pesticides, and sediment. These large changes in physical and chemical indices are associated with only a small drop in the multimetric index of community condition 
(fig. 12). Only small changes in physical and chemical condition indices occur between Yakima River below Toppenish and Yakima River at Kiona; however, the condition of the invertebrate community improves. This improvement occurs despite additional municipal wastewater discharges (Sunnyside, Mabton, Grandview, and Prosser), irrigation return flows (Coulee Drain, South Drain, DID No. 7, Spring Creek, and Snipes Creek), and diversions (Chandler Canal, Kennewick Canal, and Kiona Canal) that occur between Toppenish and Kiona.

Yakima River at Cle Elum is a transitional site that possesses characteristics of both smaller streams of the Cascades ecoregion and larger streams of the Columbia Basin. If the multimetric condition index is recalculated by using the reference sites for the Cascades and Eastern Cascades site group, then the condition index at Yakima River at Cle Elum decreases from 7.8 (YRCE ${ }^{2}$ in fig. 12) to 5.0 (YRCE ${ }^{1}$ in fig. 12), which changes the condition rating from unimpaired to moderately impaired. The rating of moderate concern is probably warranted because substrate stability at this site has been reduced as a result of highway construction (Interstate 90) from what would be expected for a stream in the Cascades ecoregion. Substrate instability at this site is indicated by discharge rating curves that shift with storms (Stuart McKenzie, U.S. Geological Survey, oral commun., 1995). Substrate instability does not impair the condition of Yakima River at Cle Elum relative to other sites in the large-river site group. Therefore, Yakima River at Cle Elum can be considered to be both a moderately impaired site in the Cascades ecoregion group and an unimpaired site in the large-river site group.

\section{Condition of Algal Communities}

The condition of benthic-algal communities in the Yakima River basin was determined by categorizing taxa as tolerant, intolerant, or cosmopolitan depending upon the correlation between relative abundance and nutrient concentrations and agricultural intensity (table 15). This approach was used because some algal species were not responding to nutrients in a manner consistent with the autecological guild assigned from the literature (table 22). Correlation between nutrients and algal relative abundance was also thought to provide a more direct measure of tolerance to agriculture, the main land use in the Yakima River Basin. Rare taxa, those present at less than five sites, were not used in the analysis because the limited distribution of these taxa made it difficult to assess their response to nutrient concentrations and agricultural intensity.

The reference sites used for the algal community condition index were the same ones used for determining the invertebrates community condition index (Cascades and Eastern Cascades site group-Taneum Creek, Rattlesnake Creek, South Fork Manastash Creek, and Satus Creek near Toppenish; Columbia Basin site group-Satus Creek below Dry Creek and Umtanum Creek; and large-river site group-Yakima River at Umtanum and Naches River near North Yakima). These sites were chosen because they have rich communities of algae and invertebrates, large abundances ( $>75 \%$ of total abundance) of intolerant forms (fig. 13), and low levels of metals, agricultural, and pesticide contamination.

The numerical value of the algal community condition index primarily depends upon the proportion of the community in each tolerance class (intolerant, cosmopolitan, and tolerant) and the references sites against which the community is compared. Algal community composition based on correlations with nutrients (fig. 13) was fairly similar to community composition based on autecological guilds (fig. 7) even though the analysis based on autecological guilds was not restricted to taxa that occurred at 5 or more sites. Taneum Creek, Satus Creek below Dry Creek, and Umtanum Creek were the only sites that showed considerable differences between methods. The disparity at Taneum Creek was due to Microcystis, which constituted $73 \%$ of algal abundance at this site but was not included in the correlation approach because it was only present at three sites. Umtanum Creek and Satus Creek below Dry Creek had a smaller percentage of intolerant algae and a larger percentage of cosmopolitan taxa in the correlation analysis than in the autecological analysis. This difference was due to Oscillatoria (Satus Creek below Dry Creek), which was not classified in the autecological analysis, and Epithemia sorex (Umtanum Creek) which was classified as an intolerant species (nitrogen fixer) in the autecological analysis and as a cosmopolitan species in

the correlation analysis. Despite the differences and limitations associated with these two approaches, they gave reasonably comparable characterizations of community composition. The proportion of intolerant algae oftenexceeded 50 percent in the Cascades and Eastern Cascades site group, but rarely exceeded 10 percent in the 


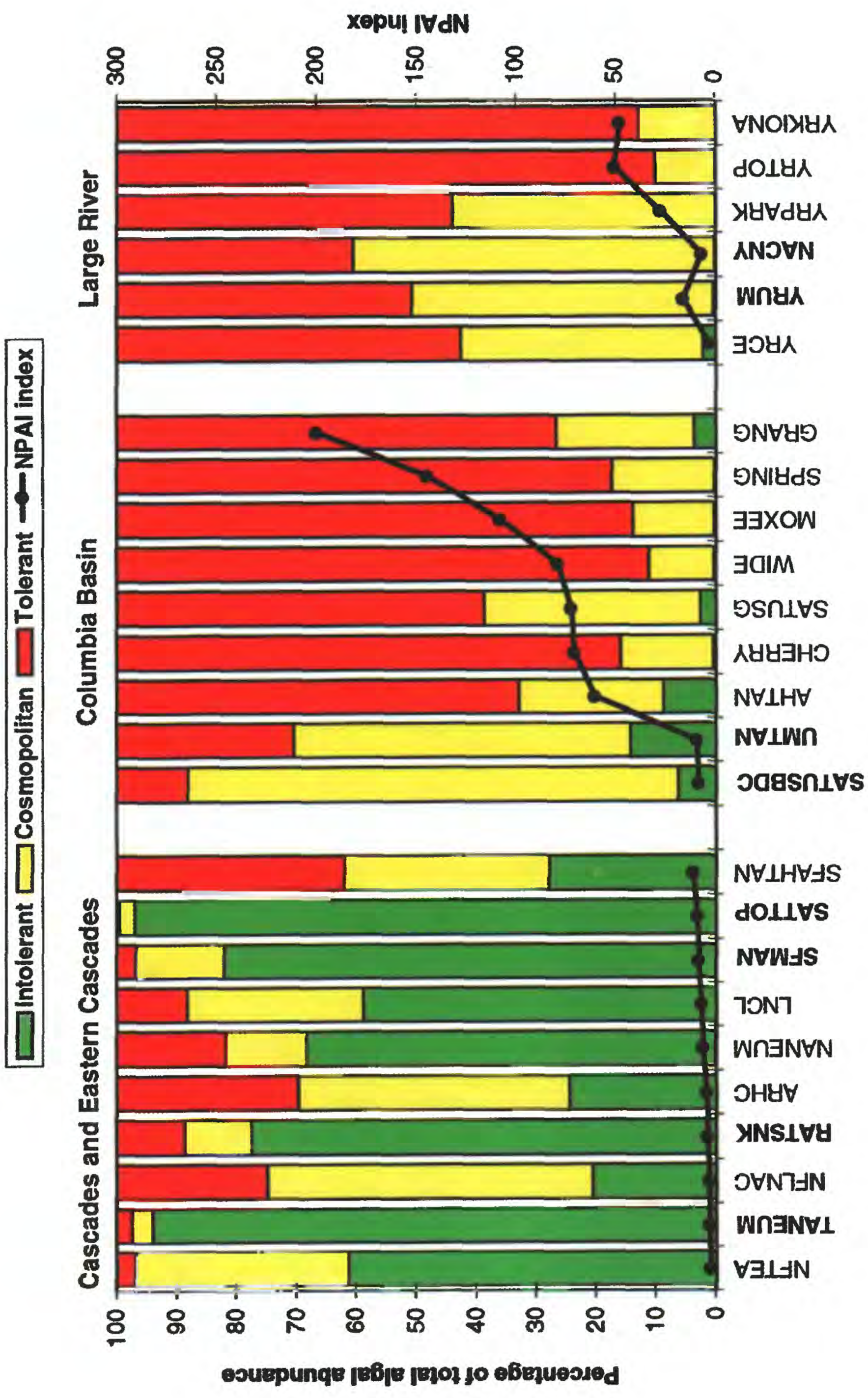

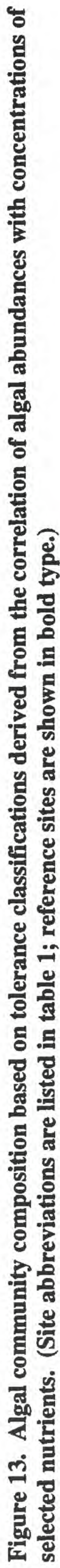


Columbia Basin and large-river site groups (fig. 13). Data from the reference sites indicate that even relatively undisturbed sites in the Columbia Basin and large-river site groups do not support many intolerant algae. The natural differences in community composition that occur among site groups make it very important that site conditions be determined by comparisons to reference sites specific to each site group.

The choice of reference site can have a large effect on the determination of site condition. This is illustrated in figure 14 for Yakima River at Cle Elum (YRCE ${ }^{1}$ and $\mathrm{YRCE}^{2}$ ), which is a large-river site located in the Cascades ecoregion. The condition of the algal community at Yakima River at Cle Elum is unimpaired (YRCE ${ }^{2}$ ) when the large-river reference sites are used and severely impaired $\left(\mathrm{YRCE}^{\mathrm{l}}\right.$ ) when reference sites from the Cascades and Eastern Cascades site group are used. These results, along with the ordination of physical and chemical site characteristics (fig. 5), suggest that even though the Yakima River at Cle Elum is in the Cascades ecoregion the size of river at this site makes it more appropriate to analyze this site as part of the large-river site group.

Site conditions are also influenced by the limits used to differentiate unimpaired, moderately impaired, and severely impaired sites. Limits of 0.25 (severely impaired/moderately impaired) and 0.75 (moderately impaired/unimpaired) were used for our studies because they are analogous to the $25^{\text {th }}$ and $75^{\text {th }}$ percentiles that are often used to differentiate extreme values. This approach to site classification was adopted because it provided a relatively conservative and objective approach to site classification. Other groups or individuals that utilize these site condition indices may want to apply their own limits for site conditions depending upon their knowledge of site conditions in the basin and the objectives of their studies.

The Columbia Basin site group, which contains sites with the highest levels of agricultural effects (NPAI and pesticide indices), also showed the highest levels of impairment (fig. 14). Four sites (Cherry Creek, Wide Hollow Creek, Moxee Drain, and Spring Creek) were rated as severely impaired, three sites (Ahtanum Creek, Satus Creek at gage, and Granger Drain) were rated as moderately impaired, and only the two reference sites were rated as unimpaired. Impairment was evident when the NPAI index exceeded 50, but the level of impairment did not appear to be linearly related to the level of the NPAI index. The distinction between the unimpaired reference sites and the impaired and moderately impaired sites was also evident in the ordination diagram (fig. 8C). Group 3a, which is on the negative limb of the axis representing the NPAI index, is composed of the unimpaired sites; Group $3 \mathrm{~b}$, which is on the positive limb of the axis, is composed of the severely impaired and moderately impaired sites. This provides additional evidence for a link between community condition and agricultural intensity.

The majority of the large-river sites were rated as unimpaired relative to the two reference sites, but the two sites farthest downstream (Yakima River at Toppenish and Yakima River at Kiona) were rated as severely impaired. Large-river sites were characterized by very low abundances of intolerant taxa (fig. 13). As with the Columbia Basin site group, impairment was evident when the NPAI index reached about 50. However, the level of impairment was higher at lower levels of the index than was evident in the Columbia Basin site group.

Three sites in the Cascades and Eastern Cascades site group were rated as moderately impaired and seven were rated as unimpaired. The degree of impairment in this site group did not appear to be related to agricultural intensity (NPAI index), which was low throughout the Cascades and Eastern Cascades site group (fig. 14). The moderate level of impairment at North Fork Little Naches River, American River at Hells Crossing, and South Fork Ahtanum River probably corresponds to land disturbance associated with silvicultural practices or road-construction activities (Stuart McKenzie, U.S. Geological Survey, written commun., 1995). Algal communities at these three sites differed from other streams in the region by having a larger proportion of cosmopolitan or tolerant algae and a smaller proportion of intolerant algae (fig. 13). The severe impairment at Yakima River at Cle Elum may be related to channel instability that has occurred as a result of the construction of Interstate Highway 90 . However, this site is rated as severely impaired only if it is compared to small streams of the Cascades and Eastern Cascades ecoregions. It is rated as unimpaired when compared to other large-river sites. Because Yakima River at Cle Elum is so much larger (drainage area $1,285 \mathrm{~km}^{2}$ and channel width $41 \mathrm{~m}$ ) than other sites in the Cascades and Eastern Cascades ecoregions (drainage areas less than $400 \mathrm{~km}^{2}$ and channel widths less than $15 \mathrm{~m}$ ), it is probably best to compare this site to other large-river sites and rate it as unimpaired. 

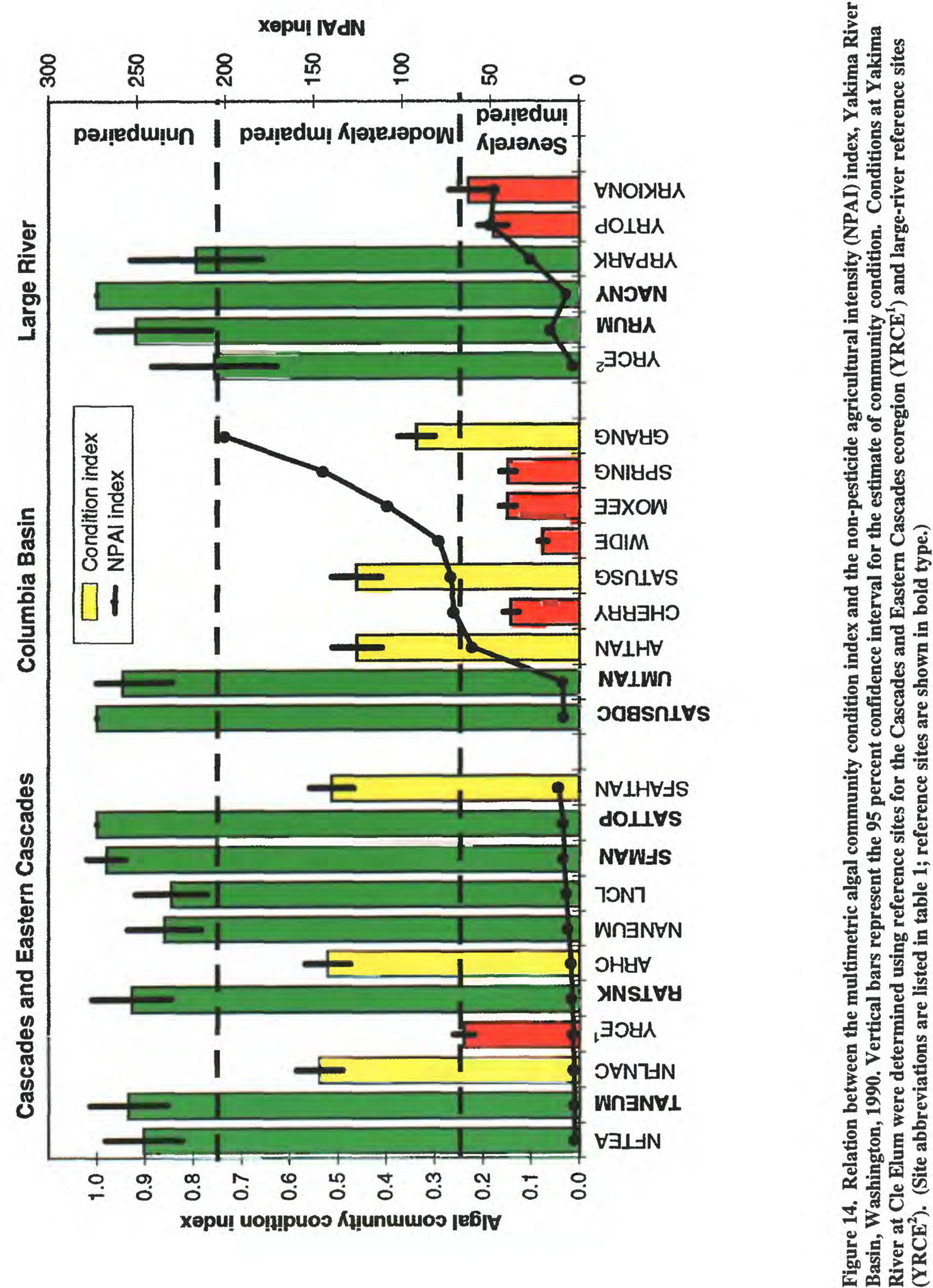
The conditions of algal communities are very good in most streams in the Cascades and Eastern Cascades ecoregions, as indicated by low agricultural intensity (NPAI values generally less than 10), low nutrient concentrations, and a dominance of intolerant algal taxa. Communities are impaired in most streams and agricultural drains in the Columbia Basin ecoregion, as well as in the Yakima River downstream from the influence of these agricultural streams, as indicated by moderate-to-high agricultural intensity (NPAI values greater than 50), relatively large nutrient concentrations, and an abundance of tolerant taxa. The water quality of large-river sites in the upper and middle segments of the Yakima River Basin (Yakima River at Cle Elum, Yakima River at Umtanum, and Naches River at North Yakima), as well as in certain tributary streams (for example, SATUSBDC and UMTAN), is relatively good. The lower Yakima River (Yakima River at Toppenish and Kiona) showed severe impairment.

\section{Integrated Assessment of Site Conditions in the Yakima River Basin}

Indices are useful tools for summarizing physical, chemical, and biological data and for relating these data to sites that are known to have good water quality (reference sites). The ability of an index to accurately describe site conditions depends on whether the index responds to environmental degradation (correlation with degradation), the form of the response (continuous linear response, threshold response), the appropriateness of reference sites, and the thresholds used to assign condition classes (unimpaired, moderately impaired, and unimpaired). The first aspect of performance (correlation with degradation) is mathematical and largely free of human bias once the indicator of degradation has been chosen. However, the assignment of condition classes and designation of reference sites can be largely subjective and may be influenced by the perceived value of the community being considered, the expected use for the resource (recreation, food production, drinking water, industry), the range of impairment, and the personal biases of the individual or group defining the classes. The site classifications presented in this study (figs. 11,12 and 14) reflect the best professional judgment of the report authors based on the physical, chemical, and biological conditions within the Yakima Basin and the available reference sites. General applicability of the condition classes outside of the data set described here has not been evaluated.

Biological indices proved to be more comprehensive indicators of site conditions than did physical and chemical measures (fig. 15) because the biological indices integrated effects arising from a broad range of factors, both measured and unmeasured. Biological conditions ranged from unimpaired to severely impaired within the basin and the level of impairment varied with the type of community considered (fig. 12). The major source of humanengendered impairment is agriculture (NPAI and pesticide indices), which primarily affected sites in the Columbia Basin ecoregion. The importance of agricultural intensity in determining the condition of biological communities is illustrated by the significant correlations between indicators of agricultural intensity (NPAI index and pesticide indices) and all biological indicators of site conditions (table 24).

Water-quality conditions in the Cascades and Eastern Cascades site group are generally good; however, the invertebrate and algal community condition indices suggest that conditions at North Fork Teanaway, North Fork Little Naches, American River at Hells Crossing, Naneum Creek, Little Naches River at Cle Elum, and South Fork Ahtanum Creek are moderately impaired (fig. 15). Impairment at North Fork Teanaway River could be attributed to metals enrichment from geological sources, but the other sites had low values for the metals index and the communities of Taneum Creek, which was enriched in metals, were not impaired. Consequently, biological impairment did not correspond to the metals index suggesting that the invertebrate and algal communities were responding to changes in environmental conditions that were not measured by the more than 140 physical and chemical variables addressed in this study.

Silviculture is the most likely factor affecting water quality in the Cascades and Eastern Cascades site group. However, it is very difficult to directly establish the effect of logging on biological site conditions because reliable, quantitative information on the intensity of silviculture is not readily available. Whatever the cause of the impairment of the invertebrate and algal communities, the fish communities were not adversely affected. This suggests that fish communities are not as sensitive an indicator of effects in the Cascades and Eastern Cascades site group as are the invertebrates and algae. The invertebrate and algal community condition indices each identified three impaired sites, but each index identified different sites as impaired. This may indicate that non-agricultural impacts differentially affect fish, invertebrates, and algae or that differences in the life spans of fish (years), invertebrates (months), and algae (weeks) may influence how each community responds. Regardless of the cause, 


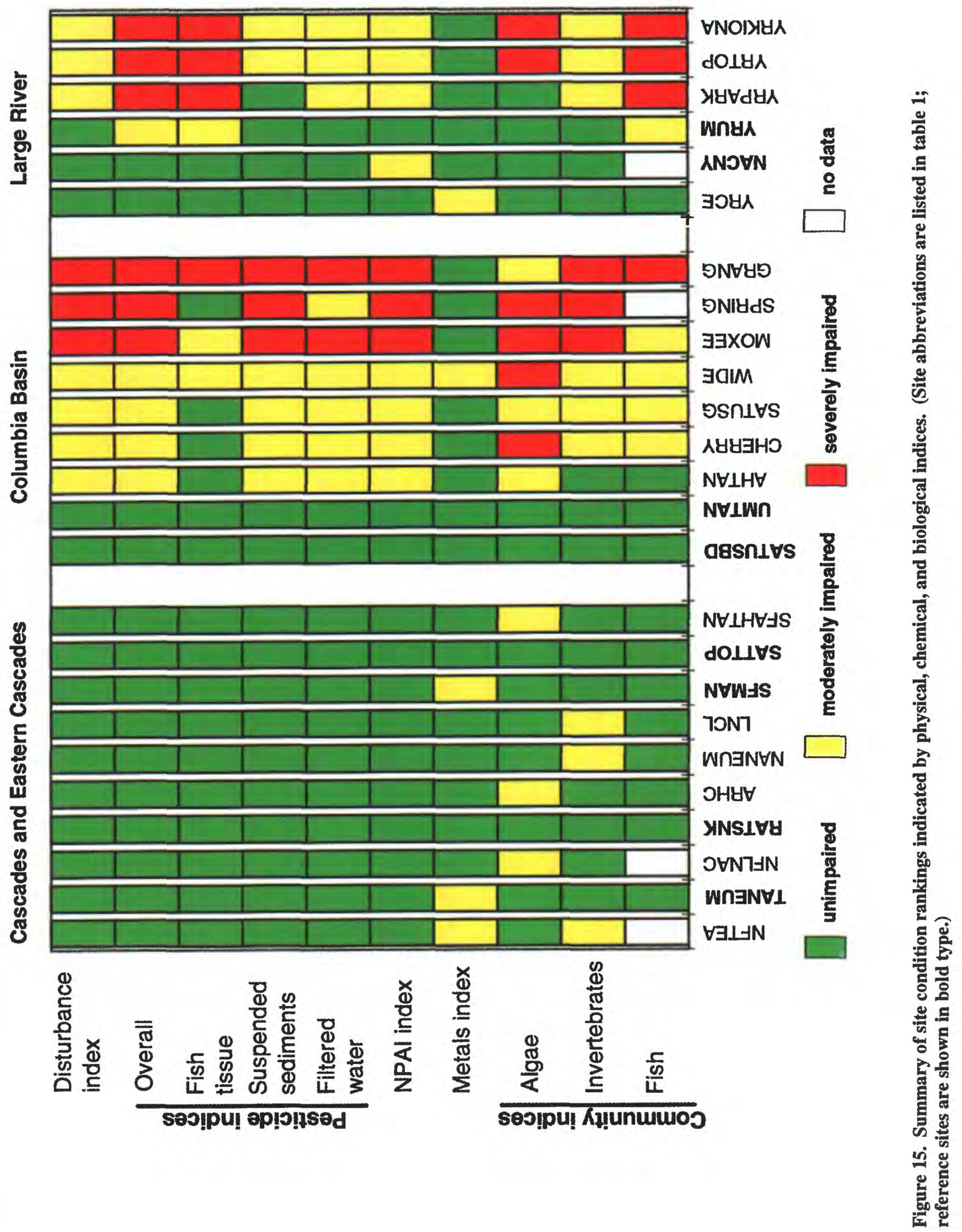




\section{Table 24. Spearman rank correlations between indices used to describe physical, chemical, and biological site conditions}

[All correlations are based on data from 25 sites except for fish, which are based on 21 sites, and pesticides in bed sediment, which are based on data from 17 sites. Significant correlations $(0.05 \leq p>0.01)$ are noted with an asterisk $(*)$, highly significant correlations $(p \leq 0.01)$ are noted with two asterisks $(* *)$.

\begin{tabular}{|c|c|c|c|c|c|c|c|c|c|}
\hline & \multirow[b]{2}{*}{ Invertebrates } & \multirow[b]{2}{*}{ Algae } & \multirow[b]{2}{*}{ Metals } & \multirow[b]{2}{*}{ NPAI } & \multicolumn{4}{|c|}{ Indices of pesticides in: } & \multirow[b]{2}{*}{ Disturbance } \\
\hline & & & & & $\begin{array}{l}\text { Filtered } \\
\text { water }\end{array}$ & $\begin{array}{l}\text { Suspended } \\
\text { sediment }\end{array}$ & $\begin{array}{c}\text { Bed } \\
\text { sediment }\end{array}$ & $\begin{array}{l}\text { Fish } \\
\text { tissue }\end{array}$ & \\
\hline Fish & $-0.71^{\star \star}$ & $-0.60^{\star \star}$ & -0.09 & $0.76^{\star \star}$ & $0.83^{\star \star}$ & $0.81^{\star \star}$ & $0.80^{\star \star}$ & $0.89^{\star \star}$ & $0.81^{\star \star}$ \\
\hline \multicolumn{2}{|l|}{ Invertebrates } & $0.78^{\star \star}$ & 0.14 & $-0.65^{\star \star}$ & $-0.78^{\star \star}$ & $-0.81^{\star \star}$ & $-0.64^{\star \star}$ & $-0.63^{\star \star}$ & $-0.70^{\star \star}$ \\
\hline \multicolumn{2}{|l|}{ Algae } & & 0.25 & $-0.67^{\star \star}$ & $-0.79^{\star \star}$ & $-0.82^{\star \star}$ & $-0.65^{\star \star}$ & $-0.55^{\star \star}$ & $-0.67^{\star \star}$ \\
\hline \multicolumn{2}{|l|}{ Metals } & & & $-0.45^{\star}$ & -0.32 & -0.27 & -0.34 & -0.19 & -0.21 \\
\hline \multicolumn{2}{|c|}{ NPAI } & & & & $0.79^{\star \star}$ & $0.81^{\star \star}$ & $0.86^{\star \star}$ & $0.77^{\star \star}$ & $0.87^{\star \star}$ \\
\hline \multicolumn{10}{|c|}{ Indices of pesticides in: } \\
\hline \multirow{2}{*}{\multicolumn{2}{|c|}{$\begin{array}{l}\text { filtered water } \\
\text { suspended sediment }\end{array}$}} & & & & & $0.86^{\star \star}$ & $0.89^{\star \star}$ & $0.62^{\star \star}$ & $0.77^{\star \star}$ \\
\hline & & & & & & & $0.80^{\star \star}$ & $0.73^{\star \star}$ & $0.86^{\star \star}$ \\
\hline \multicolumn{2}{|c|}{ bed sediment } & & & & & & & $0.70^{\star \star}$ & $0.86^{\star \star}$ \\
\hline \multicolumn{2}{|l|}{ fish tissue } & & & & & & & & $0.83^{\star \star}$ \\
\hline
\end{tabular}

the invertebrate and algal community condition indices suggest that conditions at these six sites may be declining relative to other sites in the Cascades and Eastern Cascades site group. This apparent decline could be investigated to establish the reason for the impairment and the trends in site conditions so that further declines in community condition can be avoided.

Physical, chemical, and biological effects were evident at many sites in the Columbia Basin site group. The two reference sites, Satus Creek below Dry Creek and Umtanum Creek, were the only sites in the Columbia Basin that were not impaired. All other sites had at least five indices that suggested moderate to severe impairment (fig. 15). There was a high degree of correspondence between the index of agricultural intensity (NPAI index), which primarily indicates nutrients, and all other physical and chemical indicators of site conditions, except the metals index and the index of pesticides in fish tissues. The metals index did not indicate that metals enrichment was a significant issue among sites in the Columbia Basin site group. Only one site (Wide Hollow Creek) had a moderate level of impairment, but biological impairment at this site could not be attributed to metals enrichment because the NPAI and pesticide indices also indicated moderate impairment. Pesticides in fish tissue did not show a simple relation to pesticides in other media or to the level of agricultural intensity (NPAI index). For example, Granger Drain and Spring Creek had similarly high impairment levels for the NPAI index and pesticides in filtered water and suspended sediments, but pesticides in fish tissues indicated no impairment at Spring Creek and high impairment at Granger Drain. The lack of correspondence between pesticides in fish tissues and the sources of pesticides indicates the complexity of the process by which fish are exposed to and accumulate pesticides.

The biological community condition indices derived for the Columbia Basin site group were fairly consistent with one another and with the NPAI index, particularly in their ability to differentiate unimpaired sites from moderately and severely impaired sites. They were somewhat less comparable in the identification of specific levels of impairment. Relative to the NPAI index, the fish community condition index indicated a lower level of impairment at Ahtanum Creek and Moxee Drain, the invertebrate index showed a lower level of impairment at Ahtanum Creek, and the algal index indicated a lower level of impairment at Granger Drain and greater impairment at Cherry Creek and Wide Hollow Creek.

Agriculture was the primary factor causing the degradation of biological communities in the Columbia Basin site group. The primary physical and chemical indicators of agricultural effects are nutrients, pesticides, conductivity, and substrate embeddedness, which all tend to increase with agricultural intensity. The biological effects of agriculture are manifested by a decrease in the number of species (taxa richness) and abundance of fish and 
invertebrates and a shift in algal communities to eutrophic species and higher abundances. Nutrients affect biological communities by stimulating the growth of eutrophic algae, which can cause shifts in the types of food available to invertebrate communities and the fish that feed on them. Pesticides, particularly insecticides, have toxicological effects that can directly reduce taxa richness and total abundance of the invertebrate community, which can change both the algal (diminished grazing pressure) and fish communities (reduction in food). Increased substrate embeddedness restricts the inter-rock habitats used by many benthic invertebrates, thus forcing them into less desirable habitats and making them more vulnerable to predation. Collectively, these effects constitute major shifts in the food base for invertebrates and fish, which results in lowered production of sport fishes and increased production of less economically valuable species of fish.

The Yakima River at Cle Elum was the only site in the large-river site group that was rated as unimpaired by all indicators, except metals. Generally, the level of agricultural intensity (NPAI index) was lower in the large-river site group than in the agriculturally affected tributary sites. This is reflected in lower levels of impairment for all indicators except fish, pesticides in fish tissue, and the overall pesticide index (the maximum level of impairment indicated by all pesticide indices). The pattern of impairment indicated by the fish community condition index reflects a combination of the NPAI index and the index of pesticides in fish tissue. High levels of impairment of the fish community occur at the three mainstem sites farthest downstream (Yakima River at Parker, below Toppenish, and at Kiona) where pesticides in fish tissues are also very high. These three large-river sites and Granger Drain are the only sites where anomalies were observed and where the level of pesticides in fish tissue indicates substantial impairment. This suggests a strong link between the accumulation of pesticides and the appearance of anomalies on fish. The relatively low levels of pesticides in other media (filtered water and suspended sediment) suggest that measuring pesticides in these media is not an effective means of assessing pesticide contamination in large rivers and protecting ecosystems and human health.

Pesticides that enter large rivers from tributaries where agriculture effects are very large (Moxee Drain, Granger Drain, and Spring Creek) are rapidly diluted, which would suggest that large-river sites should have fewer problems related to pesticides. However, the fish community condition index and the index of pesticides in fish tissues suggest that pesticides are readily accumulated in these systems and that even low levels of pesticides in filtered water and suspended sediment can lead to substantial impairment of the fish community and cause a risk to humans consuming these fish (Rinella and others, 1993). Lower trophic levels, invertebrates and algae, are not as sensitive an indicator of pesticide problems in large rivers as are fish. Monitoring the status of fish communities in the mainstem Yakima River provides managers with an effective tool for the protection of ecosystem and human health.

Correlation of physical and chemical site condition indices with indices of community condition (table 23) indicates that metals enrichment is not a significant factor in determining community conditions, but indices of agricultural intensity and pesticide contamination are significant. This supports the conclusion that metals enrichment is only a locally important factor, particularly in the upper Yakima River Basin, but agricultural effects (pesticides and nutrients) are the dominant water quality issue throughout the basin. Pesticide and nutrient effects are strongly correlated with one another as indicated by the correlation between the index of agricultural intensity, which is composed primarily of data on the concentration of nutrients, and indices of pesticides in filtered water and pesticides in suspended sediment. This strong relation suggests a link between the effects of pesticides and fertilizers in the Yakima River Basin that managers must consider when devising strategies for monitoring and manipulating water quality. For example, the strong correlation between the NPAI index and indicators of invertebrate and algal community condition suggests that nutrient surveys would be a cost-effective means of monitoring agricultural effects on invertebrates and algae. However, effects on fish communities might be better monitored by measuring pesticides in fish tissues because the fish community condition index is more closely related to pesticides in fish tissues than to the NPAI index.

Basin-wide correlations between biotic and physical and chemical indicators of site conditions only partially describe the relation between environmental and biological conditions. Direct examination of the response of fish, invertebrates, and algae to agricultural intensity (NPAI index) suggests some unanticipated responses that have important implications for the management of biological water quality in the Columbia Basin. Fish showed an almost linear decline in community condition (conditions decline as the value of the fish community condition index increases) as the level of agricultural intensity (NPAI index) increased (fig. 16A). This implies that any increase or decrease in agricultural intensity will be accompanied by a corresponding increase or decrease in the condition of the 

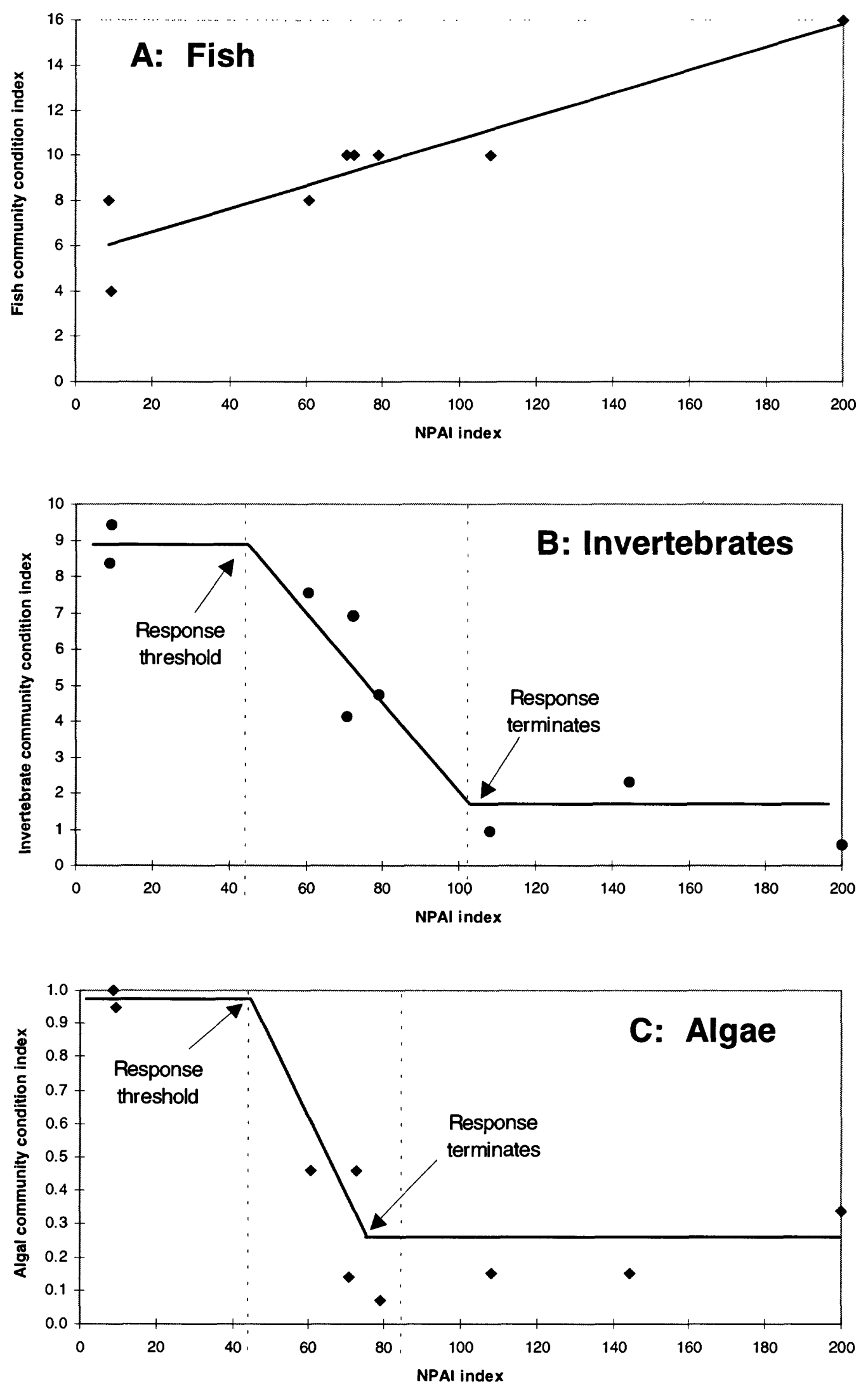

Figure 16. Response of (A) fish, (B) invertebrate, and (C) algal community condition indices to agricultural intensity (non-pesticide agricultural intensity (NPAI) index) in the Columbia Basin site group, Yakima River Basin, Washington, 1990. (The fish community condition index increases as conditions deteriorate. The invertebrate and algal community condition indices decrease as conditions worsen.) 
fish community. Therefore, mitigation efforts would be expected to produce comparable levels of improvement at any level of agricultural intensity, and the response of the fish community could be determined anywhere along the gradient that represents agricultural intensity (NPAI index). However, the data for benthic invertebrates and algae, though limited, suggest that these two communities do not display a linear response to agricultural intensity (fig. 16B and C). Instead, the condition of invertebrate and algal communities appears to deteriorate very rapidly once a relatively low threshold (NPAI index between 20 and 60) of agricultural intensity is reached (conditions decline as the invertebrate and algal community condition index decreases). This rapid decline leads to a community that shows little response to increases in agricultural intensity. This pattern of response suggests that mitigation efforts conducted at sites with high agricultural intensity will probably not produce meaningful improvement. On the other hand, relatively modest mitigation efforts at sites where the level of agricultural intensity is near to the impairment threshold will probably produce large improvements in community conditions at relatively modest costs.

These data also suggest that, if the objective of an integrated monitoring program is to understand the relation between water quality and land use, then it is critically important to determine the responses of invertebrate and algal communities at low levels of agricultural intensity, because community responses can be very rapid and can occur at relatively low land-use intensities. Monitoring programs that focus on finding high concentrations of agricultural chemicals (that is, occurrence studies) will probably not adequately represent the response of biota to agriculture. This can lead to highly erroneous conclusions regarding the effects of agriculture on human and environmental health. The manner in which the biota respond to land-use gradients is critically important to the development and implementation of cost-effective mitigation procedures. If the communities show a threshold response, then the apparent success (that is, effectiveness and cost) of a mitigation procedure will greatly depend upon where the site lies along the land-use gradient relative to the impairment threshold. If the site lies close to the impairment threshold, then mitigation is likely to show large effects and to be judged as successful. If it lies farther away, then the same mitigation techniques will probably produce little improvement and will be judged as unsuccessful. Therefore, it is critically important to understand if the community responds to the land use and, if it does respond, the form of that response must be established before cost-effective restoration can be achieved.

The response of the invertebrate and algal communities of the Columbia Basin site group to agriculture has dramatic and far-reaching consequences for managing water quality in the Yakima River Basin. Therefore, the next implementation of the NAWQA Program in the Yakima Basin should be designed to better define the existence and form of these responses. This would include sampling more sites, obtaining a better, more comprehensive representation of the agricultural gradient, and the inclusion of sites with similar levels of agricultural intensity (redundant sampling).

The multimetric and multivariate approaches provide different, but complementary, information that helped to interpret the responses of biota to natural and anthropogenic factors. The multimetric approach was able to rank the condition of communities relative to reference sites. The multivariate approach (canonical correspondence analysis) was not. This is apparent in the ordination biplots (fig. 8) where sites with different levels of impairment (red, yellow, and green symbols) were often grouped together. The multivariate approach was very good at identifying the important environmental gradients in the basin (elevation, agriculture, and stream size) and estimating the preferences of biota for certain levels of environmental variables (for example, elevation and agricultural intensity). The ability of the multivariate approach to categorize sites might have been better if additional analyses could have been conducted on the site groups identified in the initial ordination. Unfortunately, the number of sites limited the scope of the multivariate analysis. 


\section{SUMMARY AND CONCLUSIONS}

Biological investigations in the Yakima River Basin indicated linkages between biological characteristics of streams and rivers and land uses and other associated human activities that influence water quality. These investigations also elucidated relations among the physical, chemical, and biological characteristics of these streams, which can lead to development of improved strategies for the wise use and management of surface-water resources in the Yakima River Basin. Also, these investigations, which were conducted as part of the pilot studies for the U.S. Geological Survey's National Water-Quality Assessment (NAWQA) Program, have helped to form a basis for decisions on sampling design and field methods for NAWQA.

For this investigation, geographic classification of natural features (that is, Omernik's ecoregions), combined with site groupings based on physical and chemical characteristics, provided a useful organizing framework for site selection, analysis, and data interpretation. Ordination (PCA) of physical and chemical characteristics indicated that elevation, stream size (as indicated by drainage basin area), and agricultural intensity (nutrients, pesticides, turbidity, and substrate embeddedness) were the important environmental gradients in the basin. Headwater streams in two ecoregions (Cascades and Eastern Cascades) proved to be sufficiently similar (physically, chemically, and biologically) for these two ecoregions to be combined for analysis.

Previous biological investigations in the Yakima River Basin emphasized salmonids and other species of sport fish, and the physical factors (flow, temperature) that affected their abundance and survival; few basinwide studies have been published on invertebrates or algae. In this investigation, fish community composition was consistent with the fish fauna of similar river systems in the Pacific Northwest, composed primarily of salmonids and sculpins in the headwaters with more species present as gradient decreases and water temperature and stream size increase. The most common of the 33 fish taxa collected were speckled dace, rainbow trout, and Paiute sculpin; the number of taxa per site ranged from 3 to 18. In the Cascades and Eastern Cascades ecoregions, the families Salmonidae and Cottidae dominated the cool-water fish community; the rest of the basin was a warm-water fishery dominated by catostomids (suckers) and non-native species such as centrarchids (sunfish and bass). Fish community composition proved to be useful in distinguishing biological differences among sites within the Columbia Basin and large-river site groups.

Among the three biological groups studied, the highest number of taxa (193) was found among the invertebrates; 67 percent of these taxa occurred in the Cascades and(or) Eastern Cascades ecoregions, 64 percent in the Columbia Basin, and 49 percent in the large-river site groups. Insects, particularly sensitive forms such as mayflies, stoneflies, and caddisflies (EPT fauna), formed the majority of the invertebrate communities of the Cascades and Eastern Cascades and were useful in discriminating among sites within site groups. Total and EPT taxa richness tended to be lower in the Columbia Basin and large-river site groups, though insects still dominated the community richness and abundance. The distribution of stonefly richness was directly related to elevation, and stoneflies were largely confined to high-elevation streams in the Cascades and Eastern Cascades site group. Invertebrate taxa richness was directly related to the intensity of agriculture (NPAI index) and the degree of canopy closure, two factors that represent the degree to which a site has been disturbed and its elevation.

Algae were represented by a total of 134 epilithic taxa ( 26 to 76 per site) and communities were dominated by diatoms throughout the basin. Nitrogen-fixing forms were common in the low-nutrient streams of the Cascades and Eastern Cascades, whereas eutrophic forms were common in the high-nutrient streams of the Columbia Basin. Algal taxa richness and abundance were not related to biomass (chlorophyll $a$ and $b$ ), ecoregion, site group, or agricultural intensity. However, the relative abundance of autecological guilds were significantly correlated with indicators of agricultural intensity, particularly with nutrient concentrations. Sites in the Satus Creek drainage had unusually high densities of algae $\left(>3,300,000\right.$ cells $\left./ \mathrm{cm}^{2}\right)$.

Direct gradient analysis (CCA) identified the important environmental gradients that determine the distribution of organisms in the Yakima River Basin. Elevation was the primary factor controlling the distribution of all three biological communities. Agriculture (NPAI and pesticide indices) and stream size (drainage basin area) were secondary factors. Elevation affects stream habitat complexity (through the influence of gradient on water velocity and channel substrate) and climatic variables, such as temperature and precipitation, and is correlated with changes in stream size. Elevation also was significantly correlated with 43 of 54 physical and chemical site characteristics 
that were significantly correlated with the first ordination axis. This strong influence makes it difficult to separate effects resulting from land use from effects resulting from elevation. The ordination results (PCA and CCA) indicated that the influence of elevation could be substantially reduced by separating the sample sites into three three groups-small streams in the Cascades and Eastern Cascades ecoregions, small streams in the Columbia Basin ecoregion, and large rivers. The environmental optima for each taxon revealed that the biota were divided into three community types: (1) a high-elevation, cold-water, low-agriculture community, (2) a lower elevation, warm-water, low-agriculture community, and (3) a lower elevation, warm-water, moderate- to high-agriculture community.

Multimetric community condition indices indicated that there were substantial differences in the level of biological impairment within each of the three site groups (Cascades and Eastern Cascades, Columbia Basin, and large rivers), a conclusion that could not be made with the multivariate (ordination) analyses. The multimetric community condition indices, when used in conjunction with community ordinations, were able to separate biological effects associated with the major natural environmental gradients in the basin (elevation, stream size) from those related to human activities. This was accomplished by determining site conditions separately for each of the three site groups using reference sites that are specific to each site group. In this manner, the confounding effects of elevation and stream size on community structure could be separated from the major land-use effects (agriculture) that are of primary interest in determining the impact of human activities in the basin. The combination of multivariate and multimetric approaches produced an understanding of water quality in the basin that was not possible with either method alone. Fish, invertebrate and algal communities often gave somewhat different but complementary indications of site impairment because the effects of water-quality degradation are influenced by differences in the life spans of the organisms (years for fish, months for invertebrates, and weeks for algae), their mobility (fish are highly mobile, invertebrates and algae are relatively immobile), and their physiology.

The community condition indices were often a more sensitive means for detecting altered conditions than were the physical or chemical indicators (fig. 17). This was particularly evident in the Cascades and Eastern Cascades site group where invertebrate and algal communities identified some sites as having moderate levels of impairment when physical and chemical condition indices indicated no impairment. These communities were thought to be responding to the effects of logging. However, intensity of logging was not directly quantified by the physical and chemical variables measured in this study, and community degradation could not be directly tied to logging. Regardless of the cause, the invertebrate and algal community condition indices suggest that conditions at many of the sites sampled in the Cascades and Eastern Cascades may be declining.

Physical, chemical, and biological indicators of water-quality conditions showed that the Cascades and Eastern Cascades site group had the fewest impaired sites and that impairment was only moderate (fig. 17). The metals index was the only physical and chemical index that indicated any impact in the Cascades and Eastern Cascades site group. However, impairment associated with metals was not related to biological impairment.

Sites in the Columbia Basin site group were all moderately or severely impaired with the exception of the two reference sites (Umtanum Creek and Satus Creek below Dry Creek), which showed no physical, chemical, or biological impairment. Three sites were heavily affected by agriculture (Granger Drain, Moxee Drain, and Spring Creek) and were listed as severely impaired by most of the physical, chemical, and biological condition indices. Ahtanum Creek, Cherry Creek, Satus Creek at gage, and Wide Hollow Creek had similar levels (moderate) of physical and chemical impairment, but Ahtanum Creek had less biological impairment than did the other three sites. Despite the similarity in impairment levels, Cherry Creek, Satus Creek at gage, and Wide Hollow Creek all had levels of pesticides that were much higher than at Ahtanum Creek, though the levels of agricultural intensity (NPAI index) were similar. On this basis, it is probable that Ahtanum Creek is a site where community conditions could rapidly degrade if agricultural intensity or pesticide contamination were to increase even by relatively modest amounts. Biological effects of agriculture are manifested by a decrease in both taxa richness and abundance of fish and invertebrates, as well as a shift in algal communities to eutrophic species and higher abundances. Stimulation of algal growth by nutrients and possible toxicological effects of pesticides combine to cause major shifts in the food base for invertebrates and fish, which could be one factor resulting in lowered production of sport fishes and increases in less desirable species of fish. 


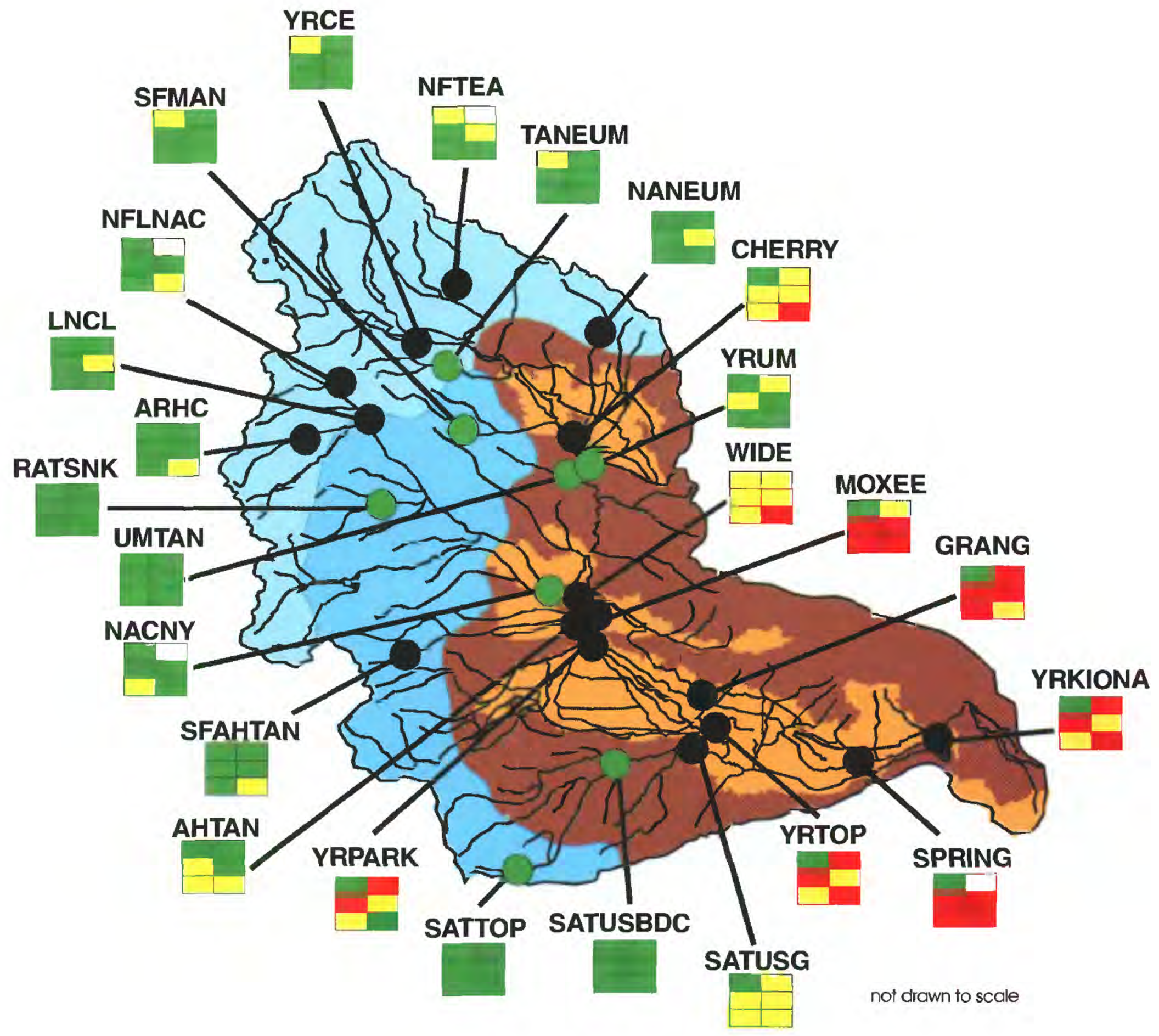

\section{EXPLANATION}

Basin features

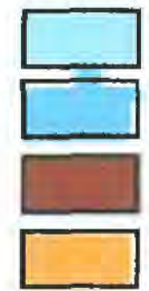

Cascades ecoregion

Eastern Cascades ecoregion

Columbia Basin ecoregion

Irrigated agriculture

Sampling sites

Sampling site

Reference site
Levels of impairment

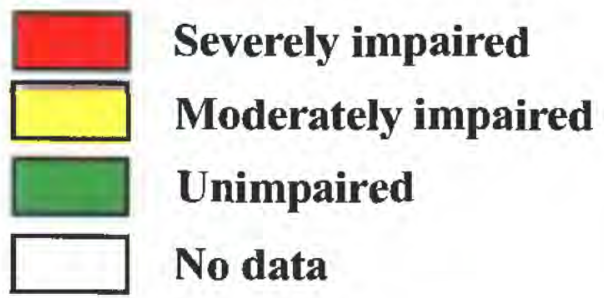

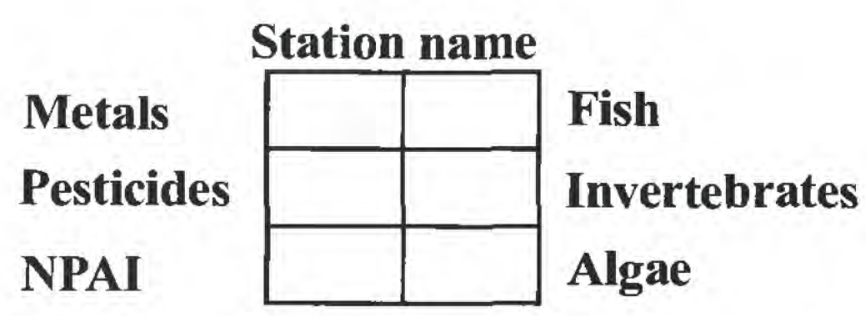

Figure 17. Map showing site condition ratings based on fish, invertebrate, and algal community condition indices and indices of metals enrichment, agricultural intensity, pesticides contamination, and disturbance. (Site abbreviations are listed in table 1.) 
Large-river sites located downstream from the city of Yakima had moderate to severe levels of impairment (fig. 17). Severe impairment of fish communities at these sites was associated with high levels of pesticides in fish tissues and the presence of external anomalies on fish. External anomalies were found at only one other site in the Yakima River Basin, Granger Drain, where the level of pesticides in fish tissue was high and there was substantial impairment of the fish community. Concentrations of pesticides in filtered water and suspended sediment were low at the severely impaired large-river sites suggesting that measuring pesticides in these media is not an effective means of assessing pesticide contamination and protecting ecosystem and human health in large rivers. Assessment of fish community conditions and the concentrations of pesticides in fish tissues were better indicators of site conditions.

The condition of invertebrate and algal communities also indicated moderate to severe impairment at large-river sites downstream from the city of Yakima. Factors influencing fish, invertebrate, and algal communities at largeriver sites include irrigation and power diversions, municipal wastewater discharges, and irrigation return flows. Yakima River at Cle Elum is a large-river site located in the Cascades ecoregion. It is the only large-river site that showed no biological impairment when compared to other large-river sites, but it showed moderate to severe impairment when compared to smaller streams in the Cascades ecoregion. Therefore, Yakima River at Cle Elum is impaired relative to other sites in the Cascades ecoregion and unimpaired relative to other large-river sites.

The manner in which invertebrates and algae respond to agricultural intensity in the Columbia Basin site group has important implications for water-quality management in the Yakima River Basin. The data suggest that invertebrates and algae exhibit a threshold effect at relatively low levels of agricultural intensity. The condition of these communities degrades rapidly when the NPAI index exceeds 50. The resulting community of tolerant organisms does not change as agriculture intensity increases. Consequently, the success of monitoring and mitigation programs depend upon what portion of the agricultural response curve is included in the study. If monitoring is restricted to moderate to high levels of agricultural intensity, then it is likely that the community will not exhibit a response to agricultural intensity, because the levels of agricultural intensity being investigated are all well above the threshold response level. Similarly, if mitigation is attempted at moderate to high levels of agricultural intensity, it is unlikely that there will be much improvement in community condition unless the mitigation is sufficient to reduce agricultural intensity beyond the impairment threshold. Successful monitoring and restoration depends on establishing whether the communities respond to agriculture, understanding the form of the response, and determining the portion of the response curve that is represented in the data set.

\section{REFERENCES CITED}

Barbour, M.T., Stribling, J.B., Gerritsen, J., and Karr, J.R., 1996, Biological criteria. Technical guidance for streams and small rivers: Washington, DC, Office of Water, U.S. Environmental Protection Agency, EPA/822/B-96/001.

Bode, R.W., 1988, Quality Assurance Work Plan for Biological Stream Monitoring in New York State: New York State Department of Environmental Conservation.

Bold, H.C., and Wynne, M.J., 1978, Introduction to the algae. Structure and reproduction: Englewood Cliffs, New Jersey, Prentice-Hall, Inc., 706 p.

Bonneville Power Administration, August 1988, Issue alert, Yakima and Klickitat salmon and steelhead: Report BP954, 8 p.

Braak, C.J.F. ter, 1985, Correspondence analysis of incidence and abundance data: Properties in terms of a unimodal response model: Biometrics, v. 41, p. 859-873.

1987, Ordination, chapter 5, in Jongman, R.H.G., ter Braak, C.J.F., and van Tongeren, O.F.R., eds., 1987, Data analysis in community and landscape ecology: Pudoc Wageningen 299 p. 1987-1992, CANOCO - a FORTRAN program for Canonical Community Ordination: Microcomputer Power, Ithaca, New York, USA.

Bramblett, R.G., and Fausch, K.D., 1991, Variable fish communities and the index of biotic integrity in a western Great Plains river: Transactions of the American Fisheries Society, v. 120, p. 752-769.

Britton, L.J., and Greeson, P.E., 1989, Methods for collection and analysis of aquatic biological and microbiological samples: U.S. Geological Survey Techniques of Water-Resources Investigations, book 5, chapter A4, $363 \mathrm{p}$. 
Carter, J.L., Fend, S.V., and Kennelly, S.S., 1996, The relationships among three habitat scales and stream benthic invertebrate community structure: Freshwater Biology, v. 35, p. 281-299.

Chandler, G.L., Maret, T.R., and Zaroban, D.W., 1993, Protocols for assessment of biotic integrity (fish) in Idaho streams: Idaho Department of Health and Welfare, Division of Environmental Quality, Water Quality Monitoring Protocols-Report No. 6. 40 p.

Cholnoky, B.J., 1958, Hydrobiologische untersuchungen in Transvall II., Selbstreinigung im Jukskei-Crocodile flusssystem: Hydrobiologia (The Hague), v. 11, p. 205-266.

1968, Die okologie der diatomeen in binnengewasser: Lehre, West Germany, J. Cramer Publishers, 699 p.

Courtemanch, D.L., and Davies, S.P., 1987, A coefficient of community loss to assess detrimental change in aquatic communities: Water Research, v. 21, p. 217-222.

Cuffney, T.F., Gurtz, M.E., and Meador, M.R., 1993a, Methods for collecting benthic invertebrate samples as part of the National Water-Quality Assessment Program: U.S. Geological Survey Open-File Report 93-406, 66 p. $1993 \mathrm{~b}$, Guidelines for the processing and quality assurance of benthic invertebrate samples collected as part of the National Water-Quality Assessment Program: U.S. Geological Survey Open-File Report 93$407,80 \mathrm{p}$.

Cummins, K.W., 1973, Trophic relations of aquatic insects: Annual Review of Entomology, v. 18, p. 183-206. 1974, Structure and function of stream ecosystems: BioScience, v. 24, p. 631-641.

Embrey, S.S., 1992, Surface-water-quality assessment of the Yakima River Basin, Washington: Areal distribution of fecal-indicator bacteria, July 1988: U.S. Geological Survey Open-File Report 91-4073.

Fairchild, G.W., and Lowe, R.L., 1984, Artificial substrates which release nutrients: Effects on periphyton and invertebrate succession: Hydrobiologia, v. 114, p. 29-37.

Fairchild, G.W., Lowe, R.L., and Richardson, W.B., 1985, Algal periphyton growth on nutrient-diffusing substrates: an in situ bioassay: Ecology, v. 66, p. 465-472.

Fausch, K.D., Lyons, J., Karr, J.R., and Angermeier, P.L., 1990, Fish communities as indicators of environmental degradation, in Adams, S.M., ed., Biological indicators of stress in fish: Bethesda, Md., American Fisheries Society, p. 123-144.

Freeman, M.C., 1986, The role of nitrogen and phosphorus in the development of Cladophora glomerata (L.) Kutzing in the Manawatu River, New Zealand: Hydrobiologia, v. 131, p. 23-30.

Fuhrer, G.J., McKenzie, S.W., Rinella, J.F., Sanzolone, R.F., and Skach, K.A., 1994, Surface-water-quality assessment of the Yakima River Basin in Washington: Analysis of major and minor elements in finegrained streambed sediment, 1987, with sections on Geological overview and geologic classification of low-order stream sampling sites, by Marshall W. Gannett: U.S. Geological Survey Open-File Report 93$30,226 \mathrm{p}$.

Fuhrer, G.J., Cain, D.J., McKenzie, S.W., Rinella, J.F., Crawford, J.K., Skach, K.A., and Hornberger, M.I., 1995, Surface-water-quality assessment of the Yakima River Basin in Washington: Spatial and temporal distribution of trace elements in water, sediment, and aquatic biota, 1987-91: U.S. Geological Survey Open-File Report 95-440, 190 p.

1996, Surface-water-quality assessment of the Yakima River Basin in Washington: Spatial and temporal distribution of trace elements in water, sediment, and aquatic biota, 1987-91: U.S. Geological Survey Open-File Report 95-440, 190 p.

Fuhrer, G.J., Fluter, S.L., McKenzie, S.W., Rinella, J.F., Crawford, J.K., Cain, D.J., and Skach, K.A., 1994, Surfacewater-quality assessment of the Yakima River Basin in Washington: Trace element data for water, sediment, and aquatic biota, 1987-91: U.S. Geological Survey Open-File Report 94-308, 223 p.

Fuhrer, G.J., Shelley, L.F., McKenzie, S.W., Rinella, J.F., Crawford, J.K, Cain, D.J., Hornberger, M.I., Bridges, J.L., and Skach, K.A., 1994, Surface-water quality assessment of the Yakima River Basin in Washington: major and minor-element data for sediment, water, and aquatic biota, 1987-1991: U.S. Geological Survey Open-File Report 94-64, 154 p.

Gauch, H.G., Jr., 1982, Multivariate analysis in community ecology: New York, Cambridge University Press, 298 p.

Geitler, Lothar, 1977, Zur Entwicklungsgeschichte der Epithemiaceen Epithemia, Rhopalodia, und Denticula (Diatomophyceae) und ihre vermutlich symbiotischen Spharoidkorper: Pl. Syst. Evolution, v. 128, p. 259-275.

Gilliom, R.J., Alley, W.M., and Gurtz, M.E., 1995, Design of the National Water-Quality Assessment Program: occurrence and distribution of water-quality conditions: U.S. Geological Survey Circular 1112, $33 \mathrm{p}$.

Hilsenhoff, W.L., 1987, An improved biotic index of organic stream pollution: Great Lakes Entomologist, v. 20, p. 1-39. 
1988, Rapid field assessment of organic pollution with a family-level biotic index: Journal of the North American Benthological Society, v. 7, p. 65-68.

Hirsch, R.M., Alley, W.M., and Wilber, W.G., 1988, Concepts for a National Water-Quality Assessment Program:

U.S. Geological Survey Circular 1021, $42 \mathrm{p}$.

Hughes, R.M., and Gammon, J.R., 1987, Longitudinal changes in fish assemblages and water quality in the Willamette River, Oregon: Transactions of the American Fisheries Society, v. 116, p. 196-209.

Hustedt, Friedrich, 1937-38, Systematische and Okologische Untersuchungen uber die Diatomeenflora von Java, Bali, und Sumatra: Archives fur Hydrobiologie (Supplement-Band), v. 15, p. 131-177.

Hutchinson, G.E., 1957, A Treatise on Limnology, v. I: New York, N.Y., John Wiley \& Sons, Inc., 1,015 p.

Hynes, H.B.N., 1970, The Ecology of Running Waters: Toronto, Ontario, Canada, University of Toronto Press, $555 \mathrm{p}$.

1975, The stream and its valley: Verhandlungen Internationale fur Theoretische und Angewandte Limnologie, v. 19, p. 1-15.

Jongman, R.H.G., ter Braak, C.J.F., and van Tongeren, O.F.R., eds., 1987, Data analysis in community and landscape ecology: Pudoc Wageningen 299 p.

Karr, J.R., Fausch, K.D., Angermeier, P.L., Yant, P.R., and Schlosser, I.J., 1986, Assessing biological integrity in running waters: a method and its rationale: Illinois Natural History Survey, Special Publication 5, $28 \mathrm{p}$.

Leahy, P.P., Rosenshein, J.S., and Knopman, D.S., 1990, Implementation plan for the National Water-Quality Assessment Program: U.S. Geological Survey Open-File Report 90-174, 10 p.

Leland, H.V., 1995, Distribution of phytobenthos in the Yakima River basin, Washington, in relation to geology, land use and other environmental factors: Canadian Journal of Fisheries and Aquatic Sciences, v. 52, p. 1108-1129.

Lenat, D.R., 1988, Water quality assessment of streams using a qualitative collection method for benthic macroinvertebrates: Journal of the North American Benthological Society, v. 7, p. 222-233.

Li, H.W., Schreck, C.B., Bond, C.E., and Rexstad, Eric, 1987, Factors influencing changes in fish assemblages of Pacific Northwest streams, in Matthews, W.J., and Heins, D.C., eds., Community and evolutionary ecology of North American stream fishes: Norman, Okla., University of Oklahoma Press, p. 193-202.

Lin, C.K., 1977, Accumulation of water soluble phosphorus and hydrolysis of polyphosphates by Cladophora glomerata (Chlorophyceae): Journal of Phycology, v. 13, p. 46-51.

Lowe, R.L., 1974, Environmental requirements and pollution tolerance of freshwater diatoms: Cincinnati, Ohio, U.S. Environmental Protection Agency, National Environmental Research Center, Office of Research and Development, EPA-670/4-74-005, 334 p.

McKenzie, S.W., and Rinella, J.F., 1987, Surface-water-quality assessment of the Yakima River Basin, Washington: Project description: U.S. Geological Survey Open-File Report 87-238, 35 p.

Meador, M.R., Cuffney, T.F., and Gurtz, M.E., 1993a, Methods for sampling fish communities as part of the National Water-Quality Assessment Program: U.S. Geological Survey Open-File Report 93-104, 40 p.

Meador, M.R., Hupp, C.R., Cuffney, T.F., and Gurtz, M.E., 1993b, Methods for characterizing stream habitat as part of the National Water-Quality Assessment Program: U.S. Geological Survey Open-File Report 93-408, $48 \mathrm{p}$.

Merritt, R.W., and Cummins, K.W., 1996, An Introduction to the Aquatic Insects of North America, $3^{\text {rd }}$ Edition: Dubuque, Iowa, Kendall/Hunt Publishing Company, 862 p.

Ohio Environmental Protection Agency, 1987, Biological criteria for the protection of aquatic life, Volumes I-III: Columbus, Division of Water Quality Monitoring, Surface Water Section, 351 p.

Omernik, J.M., 1987, Ecoregions of the conterminous United States: Annals of the Association of American Geographers, v. 77, p. 118-125.

Patten, B.G., Thompson, R.B., and Gronlund, W.D., 1970, Distribution and abundance of fish in the Yakima River, Washington, April 1957 to May 1958: U.S. Fish and Wildlife Service, Special Scientific Report-Fisheries No. 603, 27 p.

Plafkin, J.L., Barbour, M.T., Porter, K.D., Gross, S.K., and Hughes, R.M., 1989, Rapid bioassessment protocols for use in streams and rivers. Benthic Macroinvertebrates and Fish: Washington, DC, Office of Water Regulations and Standards, U.S. Environmental Protection Agency, EPA/444/4-89/001.

Plotnikoff, R.W., 1995, Ambient monitoring instream biological assessment: Progress report of 1993 pilot survey: Washington State Department of Ecology, Publication No. 95-333, 45 p. 
Porter, S.D., Cuffney, T.F., Gurtz, M.E., and Meador, M.R., 1993, Methods for collecting algal samples as part of the National Water-Quality Assessment Program: U.S. Geological Survey Open-File Report 93-409, $39 \mathrm{p}$.

Prescott, G.W., 1962, Algae of the western Great Lakes area: Dubugue, IA, W.C. Brown Publishers, 977 p.

Reash, R.J., 1995, Biocriteria: a regulated industry perspective, in Davies, W.S., and Simon, T.P., eds., Biological assessment and criteria: tools for water resource planning and decision making: Lewis Publishers, p. 153-166.

Rinella, J.F., Hamilton, P.A., and McKenzie, S.W., 1993, Persistence of the DDT pesticide in the Yakima River Basin, Washington: U.S. Geological Circular 1090, 24 p.

Rinella, J.F., McKenzie, S.W., and Fuhrer, G.J., 1992, Surface-water-quality assessment of the Yakima River basin, Washington: analysis of available water-quality data through 1985 water year: U.S. Geological Survey Open-File Report 91-453, 244 p.

Rinella, J.F., McKenzie, S.W., Crawford, J.K., Foreman, W.T., Gates, P.M., Fuhrer, G.J., and Janet, M.L., 1992, Surface-water-quality assessment of the Yakima River Basin, Washington: Pesticides and other traceorganic compound data for water, sediment, soil, and aquatic biota, 1987-91: U.S. Geological Survey Open-File Report 92-644, 154 p.

Robins, C.R., Bailey, R.M., Bond, C.E., Brooker, J.R., Lachner, E.A., Lea, R.N., and Scott W.B., 1991, Common and scientific names of fishes from the United States and Canada: American Fisheries Society, Special Publication 20, Bethesda, Maryland, 183 p.

Ryder, J.L., Sanzolone, R.F., Fuhrer, G.J., and Mosier, E.L., 1992, Surface-water-quality assessment of the Yakima River basin in Washington: Chemical analyses of major, minor, and trace elements in fine-grained streambed sediment: U.S. Geological Survey Open-File Report 92-520, 60 p.

SAS Institute Inc., 1988, SAS/STA TM User's Guide, Release 6.03 Edition: Cary, North Carolina, SAS Institute Inc., p. 1028.

Schoeman, F.R., 1973, A systematical and ecological study of the diatom flora of Lesotho with special reference to the water quality: Pretoria, South Africa, V\&R Printers, 355 p.

Simon, T.P., and Lyons, J., 1995, Application of the index of biotic integrity to evaluate water resource integrity in freshwater ecosystems, in Davies, W.S., and Simon, T.P., eds., Biological assessment and criteria: tools for water resource planning and decision making: Lewis Publishers, p. 245-262.

U.S. Government Printing Office, 1988, The Clean Water Act as amended by the Water Quality Act of 1987. Public Law 100-4. Washington, D.C.

Van Dam, Herman, Mertens, A., and Sinkeldam, J., 1994, A coded checklist and ecological indicator values of freshwater diatoms from the Netherlands: Netherlands Journal of Aquatic Ecology, v. 28, no. 1, p. 117133.

Vannote, R.L., Minshall, G.W., Cummins, K.W., Sedell, J.R., and Cushing, C.E., 1980, The river continuum concept: Canadian Journal of Fisheries and Aquatic Sciences, v. 37, p. 130-137.

Wallace, J.B., Grubaugh, J.W., and Whiles, M.R., 1996, Biotic indices and stream ecosystem processes: results from an experimental study: Ecological Applications, v. 6, p. 140-151.

Whitton, B.A., 1970, Biology of Cladophora in freshwaters: Water Research, v. 4, p. 457-476.

Wydoski, R.S., and Whitney, R.R., 1979, Inland fishes of Washington: Seattle, University of Washington, 220 p.

Yoder, C.O., and Rankin, E.T., 1995, Biological response signatures and the area of degradation value: new tools for interpreting multimetric data, in Davies, W.S., and Simon, T.P., eds., Biological assessment and criteria: tools for water resource planning and decision making: Lewis Publishers, p. 263-286. 
Table 11. Invertebrates collected from the Yakima River Basin, Washington, during October 1990, and the number of sites where each taxon was found

[Taxa marked with an asterisk were present at five or more sites and were used in the community ordinations. A ' $\mathrm{P}$ ' indicates that the taxon was collected only in the qualitative multihabitat (QMH) samples. Number of sites sampled in each site group is given in parentheses beneath the name of the site group.]

\begin{tabular}{|c|c|c|c|c|}
\hline \multirow[b]{2}{*}{ Taxon } & \multicolumn{4}{|c|}{ Number of sites with taxon } \\
\hline & $\begin{array}{c}\text { Cascades } \\
(5)\end{array}$ & $\begin{array}{c}\text { Eastern } \\
\text { Cascades } \\
(5) \\
\end{array}$ & $\begin{array}{c}\text { Columbia } \\
\text { Basin } \\
(9) \\
\end{array}$ & $\begin{array}{l}\text { Large } \\
\text { rivers } \\
(6)\end{array}$ \\
\hline \multicolumn{5}{|l|}{ Platyhelminthes } \\
\hline Turbellaria* & 4 & 4 & 5 & 3 \\
\hline \multicolumn{5}{|l|}{ Annelida } \\
\hline \multicolumn{5}{|l|}{ Oligochaeta } \\
\hline Lumbriculidae* & 0 & 2 & 3 & 5 \\
\hline Naididae & 0 & 0 & $\mathbf{P}$ & 0 \\
\hline \multicolumn{5}{|l|}{ Tubificidae } \\
\hline Aulodrilus americanus Brinkhurst and Cook* & 2 & 3 & 2 & 0 \\
\hline Aulodrilus pluriseta (Piguet) & 0 & $\mathrm{P}$ & 1 & 3 \\
\hline Rhyacodrilus coccineus (Vejdovsky)* & 2 & 2 & 5 & 3 \\
\hline Spirosperma nikolskyi (Lastockin and Sokolskaya) & 0 & 0 & 0 & $\mathbf{P}$ \\
\hline Telmatodrilus vejdovskyi Eisen* & 4 & 4 & 5 & 2 \\
\hline \multicolumn{5}{|l|}{ Hirudinea } \\
\hline \multicolumn{5}{|l|}{ Erpobdellidae } \\
\hline Dina anoculata Moore & 0 & 0 & $\mathbf{P}$ & 0 \\
\hline Mooreobdella fervida (Verrill) & 0 & 0 & 0 & 1 \\
\hline \multicolumn{5}{|l|}{ Mollusca } \\
\hline \multicolumn{5}{|l|}{ Gastropoda } \\
\hline \multicolumn{5}{|l|}{ Ancylidae } \\
\hline Ferrissia* & 1 & 0 & 2 & 3 \\
\hline \multicolumn{5}{|l|}{ Hydrobiidae } \\
\hline Amnicola & 0 & 0 & 0 & 1 \\
\hline \multicolumn{5}{|l|}{ Lymnaeidae } \\
\hline Fossaria & 0 & 0 & 1 & 1 \\
\hline Lanx & 0 & 0 & 2 & 1 \\
\hline \multicolumn{5}{|l|}{ Physidae } \\
\hline Physella* & 0 & 0 & 4 & 1 \\
\hline \multicolumn{5}{|l|}{ Planorbidae } \\
\hline Gyraulus & 0 & 0 & 1 & 0 \\
\hline Planorbella & 0 & 0 & 1 & 0 \\
\hline Vorticifex & 0 & 0 & 1 & 1 \\
\hline \multicolumn{5}{|l|}{ Pleuroceridae } \\
\hline Juga & 0 & 0 & 1 & 0 \\
\hline \multicolumn{5}{|l|}{ Bivalvia } \\
\hline \multicolumn{5}{|l|}{ Corbiculidae } \\
\hline Corbicula fluminea (Muller) & 0 & 0 & 1 & 2 \\
\hline \multicolumn{5}{|l|}{ Sphaeriidae } \\
\hline Sphaerium & 0 & 2 & 1 & 1 \\
\hline
\end{tabular}


Table 11. Invertebrates collected from the Yakima River Basin, Washington, during October 1990, and the number of sites where each taxon was found-Continued

\begin{tabular}{|c|c|c|c|c|}
\hline \multirow[b]{2}{*}{ Taxon } & \multicolumn{4}{|c|}{ Number of sites with taxon } \\
\hline & $\begin{array}{c}\text { Cascades } \\
(5)\end{array}$ & $\begin{array}{c}\text { Eastern } \\
\text { Cascades } \\
(5) \\
\end{array}$ & $\begin{array}{c}\text { Columbia } \\
\text { Basin } \\
(9) \\
\end{array}$ & $\begin{array}{c}\text { Large } \\
\text { rivers } \\
\text { (6) } \\
\end{array}$ \\
\hline \multicolumn{5}{|l|}{ Arthropoda } \\
\hline \multicolumn{5}{|l|}{ Arachnida } \\
\hline Hydracarina* & 4 & 4 & 6 & 5 \\
\hline \multicolumn{5}{|l|}{ Crustacea } \\
\hline \multicolumn{5}{|l|}{ Amphipoda } \\
\hline \multicolumn{5}{|l|}{ Gammaridae } \\
\hline Gammarus & 0 & 0 & $P$ & 0 \\
\hline \multicolumn{5}{|l|}{ Hyalellidae } \\
\hline Hyalella azteca (Saussure)* & 1 & 0 & 6 & 2 \\
\hline \multicolumn{5}{|l|}{ Decapoda } \\
\hline \multicolumn{5}{|l|}{ Astacidae } \\
\hline Pacifastacus leniusculus (Dana)* & 1 & 1 & 3 & 1 \\
\hline \multicolumn{5}{|l|}{ Isopoda } \\
\hline \multicolumn{5}{|l|}{ Asellidae } \\
\hline Caecidotea & 0 & 0 & 2 & 1 \\
\hline Podocopa & 1 & 1 & $\mathbf{P}$ & 0 \\
\hline \multicolumn{5}{|l|}{ Insecta } \\
\hline \multicolumn{5}{|l|}{ Ephemeroptera } \\
\hline \multicolumn{5}{|l|}{ Amelitidae } \\
\hline Ameletus & $P$ & 2 & $P$ & 1 \\
\hline \multicolumn{5}{|l|}{ Baetidae } \\
\hline Acentrella insignificans (McDunnough)* & 2 & 3 & 1 & 3 \\
\hline Baetis bicaudatus Dodds* & 4 & 5 & 6 & 4 \\
\hline Baetis tricaudatus Dodds* & 4 & 5 & 7 & 6 \\
\hline Camelobaetidius & 0 & 0 & 0 & 1 \\
\hline Centroptilum & 0 & 0 & 0 & 1 \\
\hline Fallceon quilleri(Dodds) & 0 & 0 & 1 & 0 \\
\hline Procloeon & 0 & 0 & 2 & $P$ \\
\hline Pseudocloeon & 0 & 0 & 1 & 0 \\
\hline \multicolumn{5}{|l|}{ Caenidae } \\
\hline Caenis & 0 & 0 & 1 & 0 \\
\hline \multicolumn{5}{|l|}{ Ephemerellidae } \\
\hline Attenella* & 2 & 3 & 1 & 2 \\
\hline Caudatella* & 3 & 4 & $\mathrm{P}$ & 2 \\
\hline Drunella doddsi (Needham)* & 5 & 5 & 0 & 0 \\
\hline Drunella grandis (Eaton)* & 2 & 5 & 0 & 1 \\
\hline Drunella spinifera (Needham) & 2 & 1 & 0 & 0 \\
\hline Ephemerella* & 5 & 5 & 2 & 1 \\
\hline Eurylophella & 1 & 0 & 0 & 0 \\
\hline Serratella & 1 & 0 & 0 & 2 \\
\hline \multicolumn{5}{|l|}{ Heptageniidae } \\
\hline Cinygmula* & 5 & 5 & 1 & 0 \\
\hline Epeorus* & 2 & 5 & 1 & 1 \\
\hline
\end{tabular}


Table 11. Invertebrates collected from the Yakima River Basin, Washington, during October 1990, and the number of sites where each taxon was found-Continued

\begin{tabular}{|c|c|c|c|c|}
\hline \multirow[b]{2}{*}{ Taxon } & \multicolumn{4}{|c|}{ Number of sites with taxon } \\
\hline & $\begin{array}{c}\text { Cascades } \\
(5)\end{array}$ & $\begin{array}{c}\text { Eastern } \\
\text { Cascades } \\
(5)\end{array}$ & $\begin{array}{c}\text { Columbia } \\
\text { Basin } \\
(9) \\
\end{array}$ & $\begin{array}{l}\text { Large } \\
\text { rivers } \\
\text { (6) }\end{array}$ \\
\hline Heptagenia & $\mathrm{P}$ & $\mathrm{P}$ & 1 & 2 \\
\hline Ironodes & 0 & 2 & $\mathbf{P}$ & 0 \\
\hline Rhithrogena* & 5 & 5 & 2 & 4 \\
\hline Stenonema* & 0 & 0 & 3 & 2 \\
\hline \multicolumn{5}{|l|}{ Leptophlebiidae } \\
\hline Paraleptophlebia* & 5 & 4 & 6 & 3 \\
\hline \multicolumn{5}{|l|}{ Tricorythidae } \\
\hline Tricorythodes* & 2 & 0 & 6 & 2 \\
\hline \multicolumn{5}{|l|}{ Odonata } \\
\hline \multicolumn{5}{|l|}{ Calopterygidae } \\
\hline Calopteryx & 0 & 0 & 1 & 0 \\
\hline \multicolumn{5}{|l|}{ Coenagrionidae } \\
\hline Argia* & 1 & 0 & 5 & 1 \\
\hline Enallagma & 0 & 0 & 2 & $\mathrm{P}$ \\
\hline \multicolumn{5}{|l|}{ Gomphidae } \\
\hline Ophiogomphus & 0 & 0 & 1 & 0 \\
\hline \multicolumn{5}{|l|}{ Plecoptera } \\
\hline \multicolumn{5}{|l|}{ Capniidae } \\
\hline Eucapnopsis brevicauda (Claassen)* & 2 & 4 & 0 & 0 \\
\hline \multicolumn{5}{|l|}{ Chloroperlidae } \\
\hline Alloperla & $\mathbf{P}$ & 1 & 0 & 0 \\
\hline Kathroperla perdita Banks & 1 & 0 & 0 & 0 \\
\hline Paraperla frontalis (Banks) & 0 & 0 & 0 & 0 \\
\hline Sweltsa* & 5 & 5 & 0 & 1 \\
\hline \multicolumn{5}{|l|}{ Leuctridae } \\
\hline Despaxia augusta (Banks) & 1 & 1 & 1 & 1 \\
\hline Moselia infuscata (Claassen) & 0 & 1 & 0 & 0 \\
\hline Perlomyia & 2 & 1 & 0 & 0 \\
\hline \multicolumn{5}{|l|}{ Nemouridae } \\
\hline Zapada* & 5 & 5 & 1 & 1 \\
\hline \multicolumn{5}{|l|}{ Peltoperlidae } \\
\hline Yoraperla & 2 & 1 & 0 & 0 \\
\hline \multicolumn{5}{|l|}{ Perlidae } \\
\hline Calineuria californica (Banks)* & 4 & 5 & 1 & 1 \\
\hline Claassenia sabulosa (Banks) & 2 & 0 & 0 & 2 \\
\hline Doroneuria & 0 & 2 & 0 & 0 \\
\hline Hesperoperla pacifica (Banks)* & 2 & 3 & $P$ & 0 \\
\hline \multicolumn{5}{|l|}{ Perlodidae } \\
\hline Frisonia picticeps (Hanson) & 0 & 1 & 0 & 0 \\
\hline Isoperla* & 4 & 4 & 1 & 1 \\
\hline Kogotus & 0 & 0 & 1 & 0 \\
\hline Megarcys* & 2 & 3 & 0 & 0 \\
\hline Perlinodes aurea (Smith)* & 3 & 4 & 0 & 0 \\
\hline
\end{tabular}


Table 11. Invertebrates collected from the Yakima River Basin, Washington, during October 1990, and the number of sites where each taxon was found-Continued

\begin{tabular}{|c|c|c|c|c|}
\hline \multirow[b]{2}{*}{ Taxon } & \multicolumn{4}{|c|}{ Number of sites with taxon } \\
\hline & $\begin{array}{c}\text { Cascades } \\
(5)\end{array}$ & $\begin{array}{c}\text { Eastern } \\
\text { Cascades } \\
(5)\end{array}$ & $\begin{array}{c}\text { Columbia } \\
\text { Basin } \\
(9)\end{array}$ & $\begin{array}{c}\text { Large } \\
\text { rivers } \\
(6)\end{array}$ \\
\hline Skwala* & 3 & 5 & 1 & 3 \\
\hline Setvena & 1 & 1 & 0 & 0 \\
\hline \multicolumn{5}{|l|}{ Pteronarcyidae } \\
\hline Pteronarcys* & 1 & 2 & 1 & 1 \\
\hline \multicolumn{5}{|l|}{ Taeniopterygidae } \\
\hline Taenionema & 1 & 1 & 0 & 0 \\
\hline Taeniopteryx & 0 & 0 & 4 & 0 \\
\hline \multicolumn{5}{|l|}{ Hemiptera } \\
\hline \multicolumn{5}{|l|}{ Belostomatidae } \\
\hline Belostoma & 0 & 0 & $\mathbf{P}$ & 0 \\
\hline \multicolumn{5}{|l|}{ Corixidae } \\
\hline Corisella & 0 & 0 & $\mathbf{P}$ & 0 \\
\hline Hesperocorixa & 0 & 0 & $\mathbf{P}$ & 0 \\
\hline \multicolumn{5}{|l|}{ Megaloptera } \\
\hline \multicolumn{5}{|l|}{ Sialidae } \\
\hline Sialis & 1 & 0 & 1 & 0 \\
\hline \multicolumn{5}{|l|}{ Trichoptera } \\
\hline \multicolumn{5}{|l|}{ Brachycentridae } \\
\hline Brachycentrus* & 3 & 3 & 0 & 2 \\
\hline Micrasema* & 3 & 5 & $\mathbf{P}$ & 1 \\
\hline \multicolumn{5}{|l|}{ Glossosomatidae } \\
\hline Agapetus & 1 & 0 & 0 & 0 \\
\hline Anagapetus & 1 & 2 & 1 & 0 \\
\hline Glossosoma* & 2 & 2 & 4 & 3 \\
\hline Protoptila & 0 & 0 & 1 & 0 \\
\hline \multicolumn{5}{|l|}{ Helicopsychidae } \\
\hline Helicopsyche borealis (Hagen) & 0 & 0 & 1 & 0 \\
\hline \multicolumn{5}{|l|}{ Hydroptilidae } \\
\hline Agraylea & 0 & 1 & 0 & 0 \\
\hline Hydroptila* & 1 & 0 & 1 & 3 \\
\hline Leucotrichia* & 0 & 0 & 2 & 4 \\
\hline Ochrotrichia & 2 & 0 & 0 & 0 \\
\hline \multicolumn{5}{|l|}{ Hydropsychidae } \\
\hline Arctopsyche grandis (Banks)* & 3 & 4 & 0 & 0 \\
\hline Cheumatopsyche* & 1 & 1 & 5 & 3 \\
\hline Hydropsyche* & 4 & 5 & 8 & 6 \\
\hline Parapsyche & 1 & 1 & 0 & 0 \\
\hline \multicolumn{5}{|l|}{ Lepidostomatidae } \\
\hline Lepidostoma* & 3 & 5 & 0 & 0 \\
\hline \multicolumn{5}{|l|}{ Limnephilidae } \\
\hline Apatania* & 3 & 1 & $\mathbf{P}$ & 1 \\
\hline Moselyana comosa Denning & 0 & 0 & $\mathbf{P}$ & 1 \\
\hline Pedomoecus sierra Ross & 0 & 1 & 0 & 0 \\
\hline
\end{tabular}


Table 11. Invertebrates collected from the Yakima River Basin, Washington, during October 1990, and the number of sites where each taxon was found-Continued

\begin{tabular}{|c|c|c|c|c|}
\hline \multirow[b]{2}{*}{ Taxon } & \multicolumn{4}{|c|}{ Number of sites with taxon } \\
\hline & $\begin{array}{c}\text { Cascades } \\
(5)\end{array}$ & $\begin{array}{c}\text { Eastern } \\
\text { Cascades } \\
(5) \\
\end{array}$ & $\begin{array}{c}\text { Columbia } \\
\text { Basin } \\
\text { (9) }\end{array}$ & $\begin{array}{c}\text { Large } \\
\text { rivers } \\
(6)\end{array}$ \\
\hline \multicolumn{5}{|l|}{ Uenoidae } \\
\hline Neophylax & 2 & 2 & 0 & 0 \\
\hline Oligophlebodes & 0 & 1 & 0 & 0 \\
\hline \multicolumn{5}{|l|}{ Leptoceridae } \\
\hline Ceraclea & 0 & 0 & 0 & 2 \\
\hline Nectopsyche & 0 & 0 & 2 & 0 \\
\hline \multicolumn{5}{|l|}{ Philopotamidae } \\
\hline Dolophilodes & 1 & 2 & 0 & 0 \\
\hline \multicolumn{5}{|l|}{ Psychomyiidae } \\
\hline Tinodes & 1 & 1 & 0 & 0 \\
\hline \multicolumn{5}{|l|}{ Rhyacophilidae } \\
\hline Rhyacophila angelita Banks & 1 & 1 & 0 & 0 \\
\hline Rhyacophila brunnea Banks* & 5 & 3 & 1 & 1 \\
\hline Rhyacophila narvae Navas & 0 & 1 & 0 & 0 \\
\hline Rhyacophila vaccua Milne* & 3 & 4 & 1 & 1 \\
\hline Rhyacophila rotunda Banks & 0 & 1 & 0 & 0 \\
\hline \multicolumn{5}{|l|}{ Lepidoptera } \\
\hline \multicolumn{5}{|l|}{ Pyralidae } \\
\hline Petrophila* & 1 & 0 & 4 & 4 \\
\hline \multicolumn{5}{|l|}{ Coleoptera } \\
\hline \multicolumn{5}{|l|}{ Amphizoidae } \\
\hline Amphizoa & $P$ & 0 & $P$ & 0 \\
\hline \multicolumn{5}{|l|}{ Dryopidae } \\
\hline Helichus striatus LeConte & 1 & 0 & 0 & 0 \\
\hline \multicolumn{5}{|l|}{ Dytiscidae } \\
\hline Agabus & 0 & 0 & $\mathbf{P}$ & 0 \\
\hline Oreodytes & 0 & 0 & $\mathrm{P}$ & 0 \\
\hline Uvarus & 0 & 0 & $\mathbf{P}$ & 0 \\
\hline \multicolumn{5}{|l|}{ Elmidae } \\
\hline Cleptelmis & 0 & 1 & 0 & $\mathbf{P}$ \\
\hline Dubiraphia & 0 & 0 & 1 & 1 \\
\hline Heterlimnius* & 1 & 3 & 2 & $\mathbf{P}$ \\
\hline Lara & 1 & 3 & 0 & 0 \\
\hline Narpus* & 3 & 5 & 2 & 2 \\
\hline Optioservus* & 5 & 5 & 6 & 5 \\
\hline Ordobrevia nubifera (Fall) & 0 & 0 & 1 & 0 \\
\hline Zaitzevia parvula (Horn)* & 2 & 3 & 3 & 4 \\
\hline \multicolumn{5}{|l|}{ Hydrophilidae } \\
\hline Hydrochus & $\mathbf{P}$ & 0 & 0 & 0 \\
\hline Paracymus & 0 & 0 & $P$ & 0 \\
\hline \multicolumn{5}{|l|}{ Psephenidae } \\
\hline Psephenus & 0 & 0 & 1 & 0 \\
\hline
\end{tabular}


Table 11. Invertebrates collected from the Yakima River Basin, Washington, during October 1990, and the number of sites where each taxon was found-Continued

\begin{tabular}{|c|c|c|c|c|}
\hline \multirow[b]{2}{*}{ Taxon } & \multicolumn{4}{|c|}{ Number of sites with taxon } \\
\hline & $\begin{array}{c}\text { Cascades } \\
\text { (5) }\end{array}$ & $\begin{array}{c}\text { Eastern } \\
\text { Cascades } \\
\text { (5) }\end{array}$ & $\begin{array}{c}\text { Columbia } \\
\text { Basin } \\
\text { (9) }\end{array}$ & $\begin{array}{c}\text { Large } \\
\text { rivers } \\
(6)\end{array}$ \\
\hline \multicolumn{5}{|l|}{ Diptera } \\
\hline \multicolumn{5}{|l|}{ Athericidae } \\
\hline Atherix & 1 & 2 & 1 & 0 \\
\hline \multicolumn{5}{|l|}{ Ceratopogonidae } \\
\hline Bezzia* & 3 & 3 & 1 & 0 \\
\hline Culicoides & 1 & 0 & 0 & 0 \\
\hline Stilobezzia & 0 & 0 & 0 & 1 \\
\hline \multicolumn{5}{|l|}{ Chironomidae } \\
\hline \multicolumn{5}{|l|}{ Chironominae } \\
\hline Chironomus & 0 & 0 & 1 & $\mathbf{P}$ \\
\hline Cladotanytarsus & 1 & 0 & 0 & 1 \\
\hline Cryptochironomus & 0 & 0 & $\mathbf{P}$ & 1 \\
\hline Dicrotendipes & 0 & 0 & 0 & 1 \\
\hline Endochironomus & 0 & 0 & $\mathrm{P}$ & 1 \\
\hline Lauterborniella agrayloides Kieffer & 0 & 0 & $\mathbf{P}$ & 0 \\
\hline Microspectra & 0 & 0 & $\mathbf{P}$ & 0 \\
\hline Microtendipes* & 0 & 2 & 1 & 2 \\
\hline Paratanytarsus* & 2 & 2 & 3 & 1 \\
\hline Paratendipes & 1 & 0 & 0 & 0 \\
\hline Polypedilum* & 1 & $\mathbf{P}$ & 3 & 1 \\
\hline Rheotanytarsus* & 1 & 0 & 2 & 3 \\
\hline Stempellinella & 2 & 1 & 0 & 0 \\
\hline Stempellina & 2 & 0 & 0 & 0 \\
\hline Tanytarsus* & 3 & 4 & 2 & 1 \\
\hline \multicolumn{5}{|l|}{ Diamesinae } \\
\hline Diamesa & 1 & 1 & 0 & 2 \\
\hline Pagastia & 2 & 0 & 0 & 0 \\
\hline Potthastia longimana Kieffer & 0 & 0 & 0 & 1 \\
\hline \multicolumn{5}{|l|}{ Orthocladiinae } \\
\hline Brillia* & 4 & 4 & $\mathbf{P}$ & 1 \\
\hline Cardiocladius* & 1 & 1 & 6 & 4 \\
\hline Chaetocladius & 0 & $\mathrm{P}$ & 1 & 1 \\
\hline Corynoneura & 0 & 0 & 1 & 0 \\
\hline Cricotopus* & 5 & 5 & 8 & 6 \\
\hline Eukiefferiella* & 3 & 2 & 3 & 5 \\
\hline Heleniella & 0 & 0 & 0 & $\mathbf{P}$ \\
\hline Lopescladius & 0 & 0 & 0 & 1 \\
\hline Mesocricotopus & 2 & 1 & 1 & 0 \\
\hline Nanocladius & 0 & 0 & $\mathbf{P}$ & 0 \\
\hline Orthocladius* & 4 & 4 & 8 & 6 \\
\hline Paraphaenocladius & 0 & 0 & 1 & 0 \\
\hline Paratrichocladius & 1 & 1 & 2 & 0 \\
\hline Rheocricotopus & 0 & 2 & 1 & 0 \\
\hline
\end{tabular}


Table 11. Invertebrates collected from the Yakima River Basin, Washington, during October 1990, and the number of sites where each taxon was found-Continued

\begin{tabular}{|c|c|c|c|c|}
\hline \multirow[b]{2}{*}{ Taxon } & \multicolumn{4}{|c|}{ Number of sites with taxon } \\
\hline & $\begin{array}{c}\text { Cascades } \\
(5)\end{array}$ & $\begin{array}{c}\text { Eastern } \\
\text { Cascades } \\
\text { (5) }\end{array}$ & $\begin{array}{c}\text { Columbia } \\
\text { Basin } \\
\text { (9) }\end{array}$ & $\begin{array}{c}\text { Large } \\
\text { rivers } \\
(6)\end{array}$ \\
\hline Synorthocladius & 0 & 0 & 0 & 4 \\
\hline Thienemanniella* & 1 & 0 & 7 & 1 \\
\hline Tvetenia & 0 & 2 & 0 & 0 \\
\hline \multicolumn{5}{|l|}{ Tanypodinae } \\
\hline Apsectrotanypus & 0 & 0 & $\mathbf{P}$ & 0 \\
\hline Brundiniella & 0 & 1 & 0 & 0 \\
\hline Helopelopia & 0 & $\mathbf{P}$ & 0 & 0 \\
\hline Krenopelopia & 1 & 0 & 0 & 0 \\
\hline Pentaneura & 0 & 0 & $\mathbf{P}$ & 0 \\
\hline Procladius & 0 & 0 & $\mathbf{P}$ & 0 \\
\hline Thienemannimyia* & 5 & 4 & 3 & $P$ \\
\hline \multicolumn{5}{|l|}{ Empididae } \\
\hline Chelifera* & 2 & 1 & 2 & 1 \\
\hline Hemerodromia* & 1 & 0 & 5 & 2 \\
\hline \multicolumn{5}{|l|}{ Muscidae } \\
\hline Limnophora & 1 & 0 & 1 & 0 \\
\hline \multicolumn{5}{|l|}{ Psychodidae } \\
\hline Pericoma* & 5 & 4 & 0 & 0 \\
\hline \multicolumn{5}{|l|}{ Pelecorhynchidae } \\
\hline Glutops* & 3 & 3 & 0 & 0 \\
\hline Ptychopteridae & $P$ & 0 & 0 & 0 \\
\hline Sciomyzidae & 0 & 0 & $\mathbf{P}$ & 0 \\
\hline \multicolumn{5}{|l|}{ Simuliidae } \\
\hline Prosimulium & 1 & 1 & 0 & 0 \\
\hline Simulium* & 3 & 4 & 7 & 4 \\
\hline \multicolumn{5}{|l|}{ Stratiomyidae } \\
\hline Nemotelus & 0 & 0 & 1 & 0 \\
\hline \multicolumn{5}{|l|}{ Tabanidae } \\
\hline Tabanus & 2 & 0 & 0 & 0 \\
\hline \multicolumn{5}{|l|}{ Tipulidae } \\
\hline Antocha* & 5 & 5 & 5 & 3 \\
\hline Dicranota* $^{*}$ & 2 & 3 & $\mathrm{P}$ & 0 \\
\hline Hexatoma* & 5 & 4 & 0 & 0 \\
\hline Tipula & 1 & 0 & 0 & $\mathrm{P}$ \\
\hline
\end{tabular}




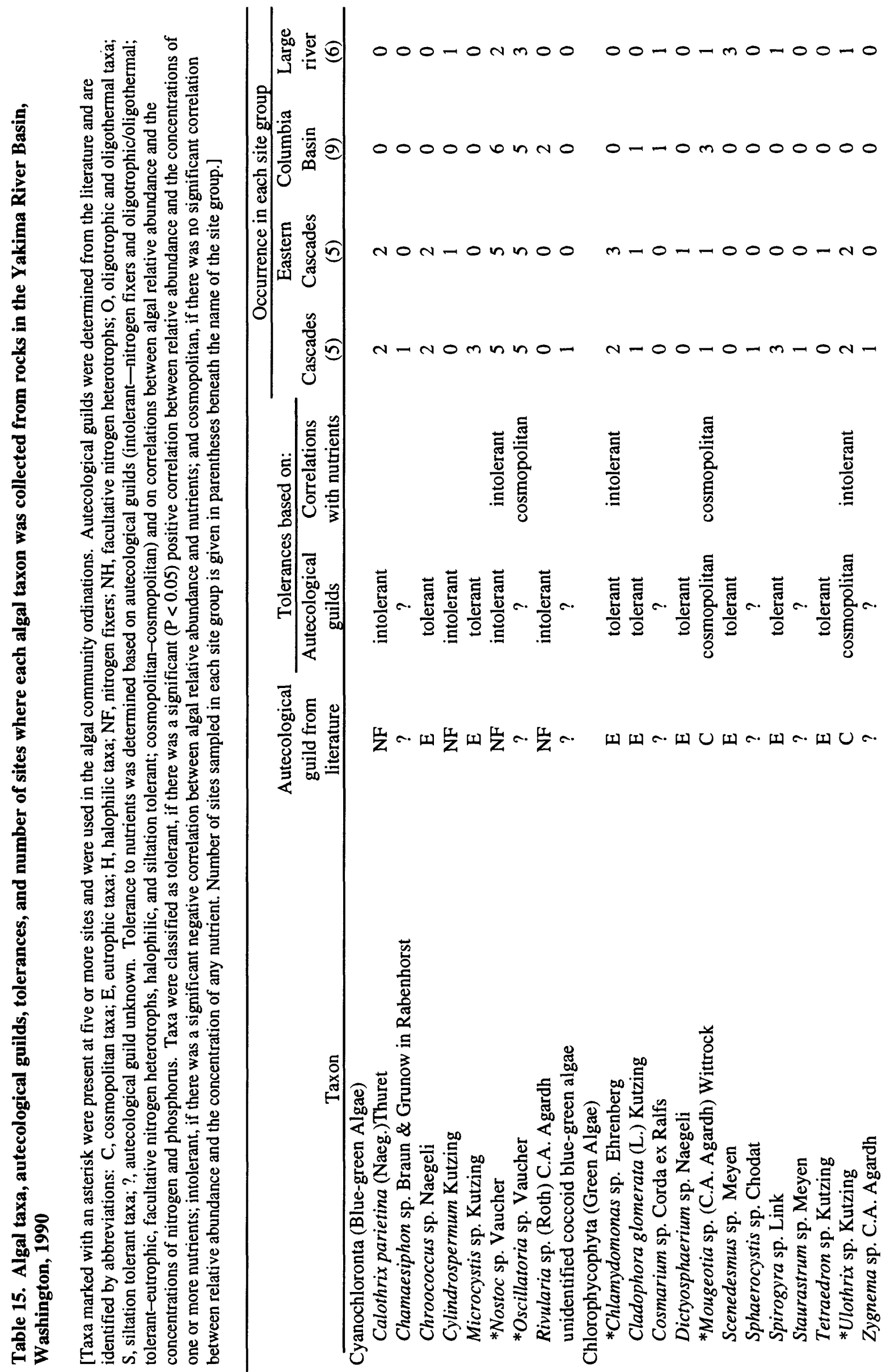




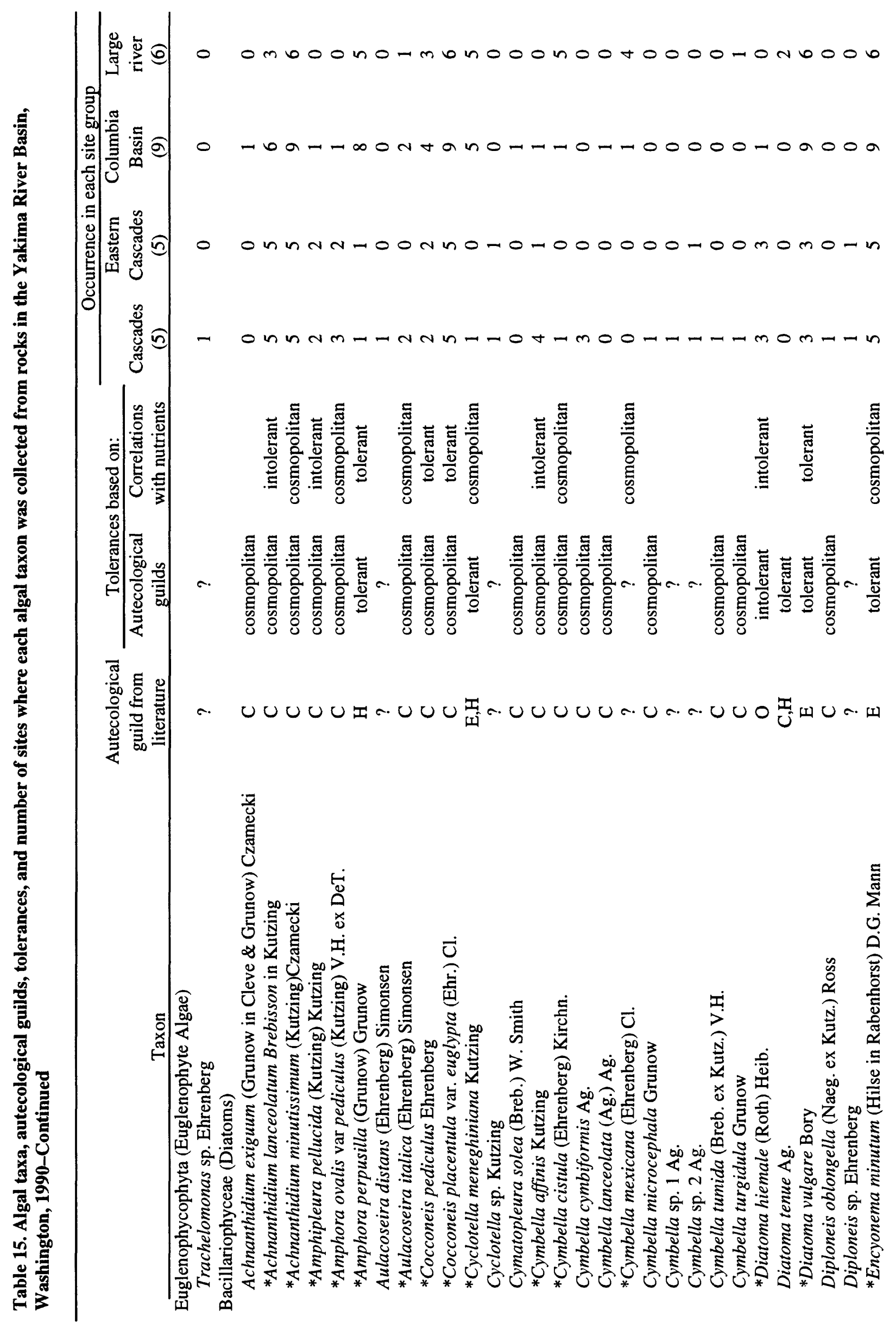




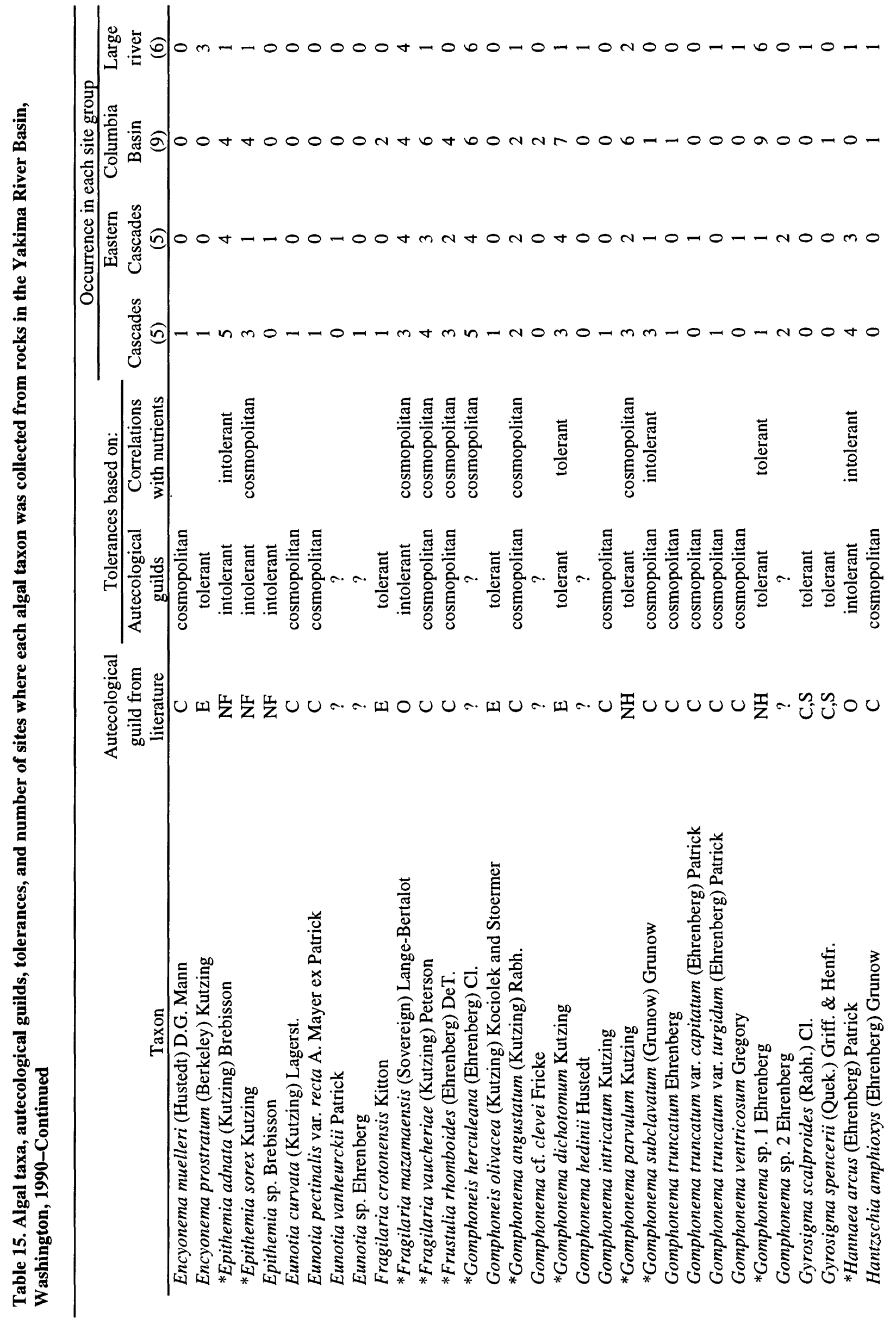




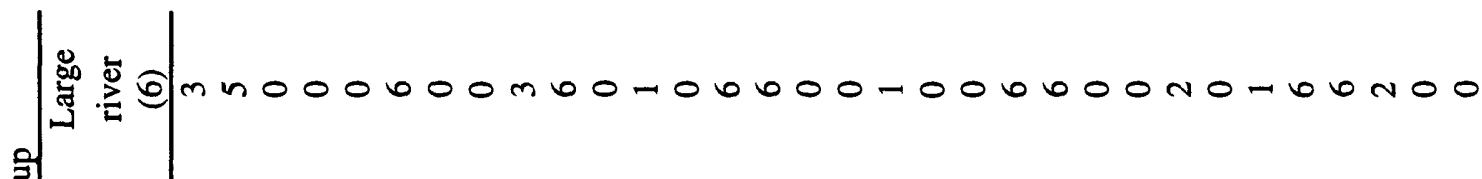

\&్

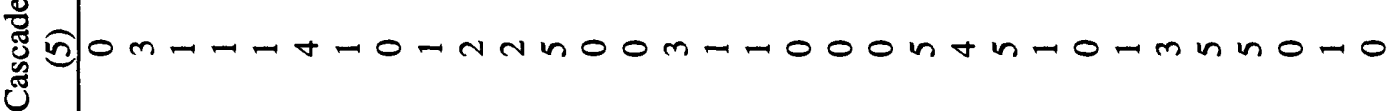
४

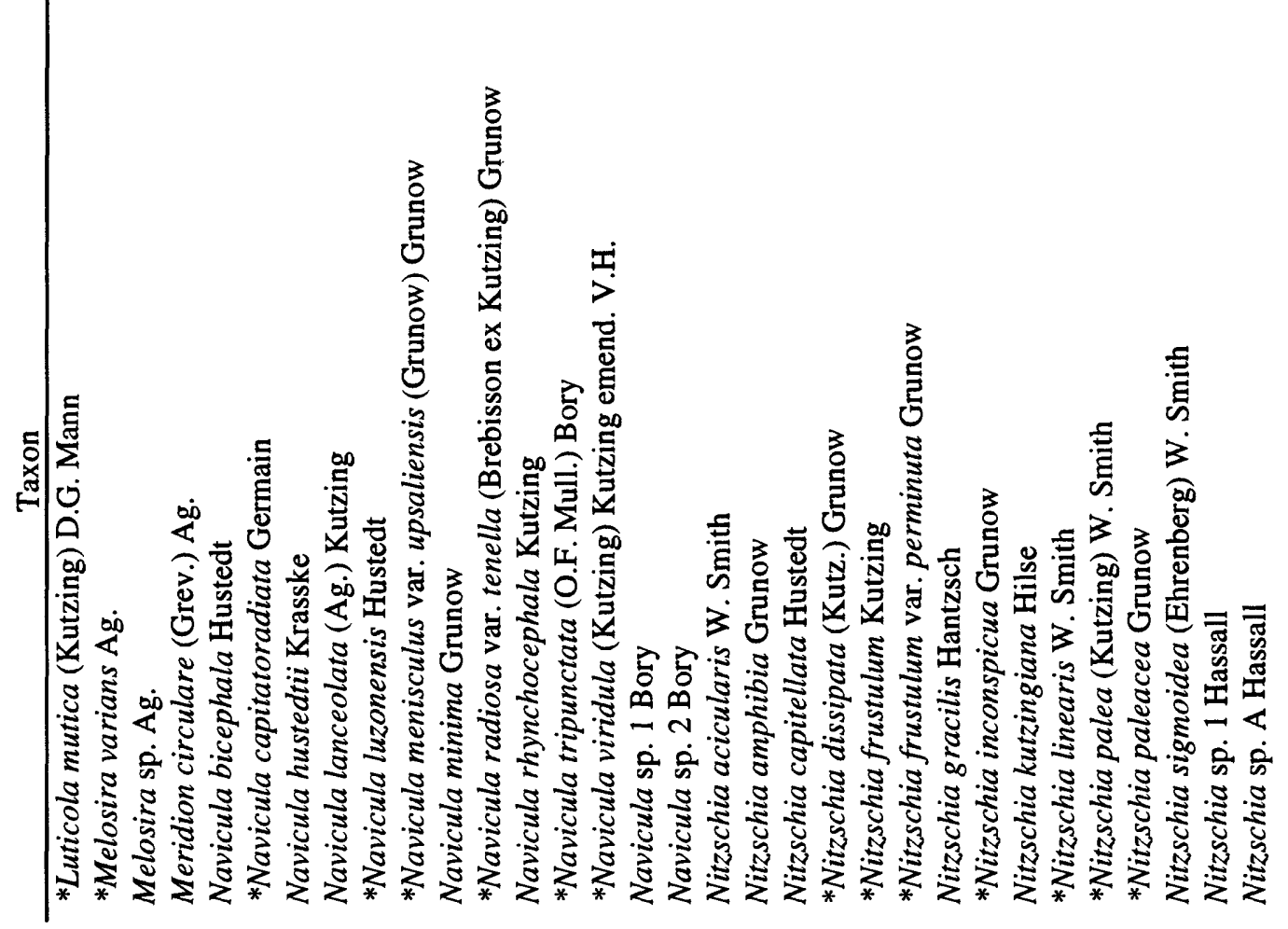




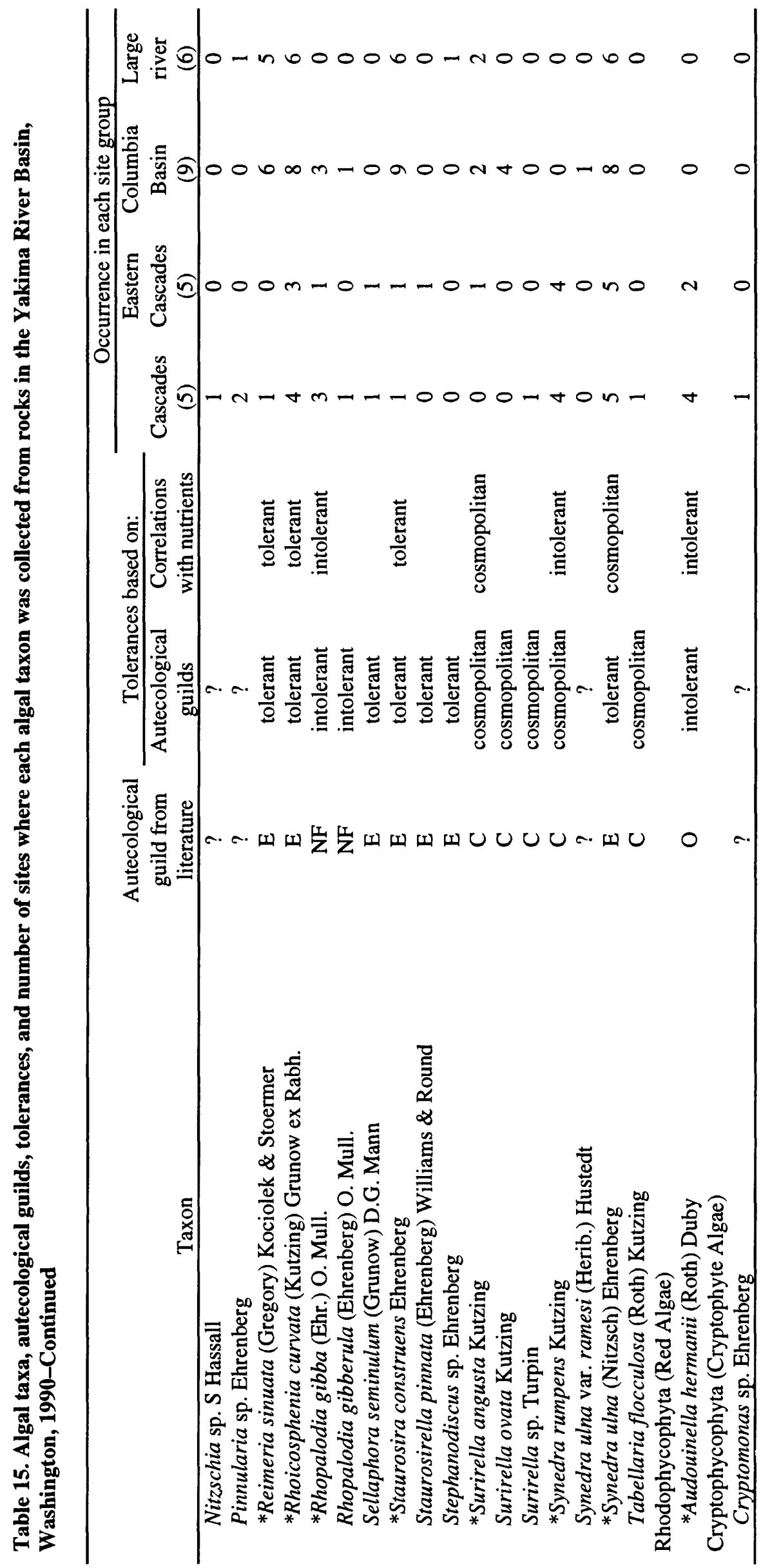




\section{APPENDICES}

Biological and environmental data used in this report are available in electronic form. These data have been converted to tab-delimited ASCII files and are available on the home page of the U.S. Geological Survey Office in Portland, Oregon (http://wwworegon.wr.usgs.gov) or by contacting the Publications Unit of the U.S. Geological Survey Office in Raleigh, 3916 Sunset Ridge Road, North Carolina 27607-6416. The following appendices describe the files that store these data.

\section{Appendix A: Summary of Physical and Chemical Site Characteristics}

Environmental data are stored in the file envdata.txt. The first line of this file identifies the contents of the file. The second line contains tab-delimited column headers that describe the contents of each column. The first column is the USGS station identification number (STAID) followed by site name (SITE) and the latitude (LAT) and longitude (LON) of the site. This is followed by a listing of 77 environmental variables. These variables are listed using the same abbreviations and order as used in table 2. These environmental variables are followed by the indices: metals (METALS), NPAI, pesticides in filtered water (PFW), pesticides in suspended sediment (PSS), pesticides in fish tissues (PTISSUE), and the overall disturbance index (DISTURB).

\section{Appendix B: Summary of Fish Community Data}

Fish community data are stored in the file fishdata.txt with sites as columns and taxa as rows. The first line of this file identifies the contents of the file and the second line identifies the contents of each column. The first column is the name of the TAXON followed by the site names listed in the order and using the abbreviations presented in table 22. The remaining rows contain the abundance data. Each row begins with the name of the taxon followed by its abundance at each site.

\section{Appendix C: Summary of Benthic Invertebrate Community Data}

Benthic invertebrate community data are stored in the two files, invquant.txt and invqual.txt, that store data obtained from quantitative and qualitative sampling, respectively. Each file stores information on abundance or presence as columns and taxa as rows. The first line of each file identifies the contents of the file and the second line identifies the contents of each column. The second row begins with the identifier TAXA followed by the functional group assignment (FG) in invquant.txt and then the site names listed in the order and using the abbreviations presented in table 22. The first column of each data line begins with the name of the taxon followed by the functional group assignment in file invquant.txt (SH-shredder, SC-scraper, CG-collector gatherer, $\mathrm{CF}$-collector filterer, and P-Predator) and then the abundance (invquant.txt) or the presence/absence (invqual.txt) of the taxon at each site. Five replicate samples are given for each site in the invquant.txt file with the exception of Ahtanum Creek and Taneum Creek where five samples were collected in each of five riffles (only the first riffle at these sites were used in the analyses). Individual samples at these sites are identified with two numbers separated by an underscore. The first number indicates the riffle from which the sample was taken and the second number indicates the replicate within the riffle (Ahtanum1_5 indicates replicate five of riffle 1).

\section{Appendix D: Summary of Algal Community Data}

Algae community data are stored in the file algdata.txt with sites as columns and taxa as rows. The first line of this file identifies the contents of the file and the second line identifies the contents of each column. The second row begins with the identifier TAXA followed by the autecological group assignment (AUTECO) and then the site names listed in the order and using the abbreviations presented in table 22. The first column of each data line begins with the name of the taxon followed by the autecological group assignment (NF-nitrogen fixers, E-eutrophic, $\mathrm{C}$ cosmopolitan, H-halophilic, O-oligotrophic/oligothermal, NH-nitrogen heterotrophs, S-siltation, ?-autecology unknown) and then the abundance of the taxon at each site. Five replicate samples are given for each site with the exception of Ahtanum Creek where five samples were collected in each of four riffles (only the first riffle at these sites were used in the analyses). Individual samples at these sites are identified with two numbers separated by an underscore. The first number indicates the riffle from which the sample was taken and the second number indicates the replicate within the riffle (Ahtanum1_5 indicates replicate five of riffle 1). 